BASILE GEORGES CAMPOS CHRISTOPOULOS

\title{
CONTROLE DE CONSTITUCIONALIDADE DE NORMAS ORÇAMENTÁRIAS: O USO DE ARGUMENTOS CONSEQUENCIALISTAS NAS DECISÕES DO SUPREMO TRIBUNAL FEDERAL
}

ORIENTADOR: FERNANDO FACURY SCAFF

TESE DE DOUTORADO

UNIVERSIDADE DE SÃO PAULO

FACULDADE DE DIREITO

SÃO PAULO, 2014 


\section{CONTROLE DE CONSTITUCIONALIDADE DE NORMAS ORÇAMENTÁRIAS: O USO DE ARGUMENTOS CONSEQUENCIALISTAS NAS DECISÕES DO SUPREMO TRIBUNAL FEDERAL}

Tese apresentada como requisito parcial para a obtenção do título de Doutor em Direito na Faculdade de Direito da Universidade de São Paulo

UNIVERSIDADE DE SÃO PAULO

FACULDADE DE DIREITO 
Aos meus avós: Celina, Basile, Aldemir e Aylton 


\section{AGRADECIMENTOS}

Gostaria de agradecer em primeiro lugar à Faculdade de Direito da Universidade de São Paulo por me ter dado a oportunidade de cursar o doutorado em direito, financiado pelo povo por meio das receitas auferidas pelo Estado.

À CAPES, pela bolsa que me foi concedida, possibilitando a minha subsistência e o financiamento dos meus estudos, mais uma vez com recursos públicos.

Ao meu orientador, Fernando Facury Scaff, pelas lições que foram passadas durante o curso e pela orientação presente e dedicada, que certamente refletem em tudo de bom que esta tese pode contribuir para a academia jurídica.

Ao Professor José Maurício Conti, pela presença em minha vida acadêmica desde a defesa da dissertação de mestrado, de cuja banca examinadora fez parte, e que desde então tem contribuído decisivamente em todos os passos trilhados.

Ao Professor Régis Fernandes de Oliveira, que me confiou a secretaria do Instituto Brasileiro de Direito Financeiro - IBDF, pelas inestimáveis contribuições à tese durante a disciplina Gasto Público, e a quem devoto grande admiração.

Ao Professor Elival da Silva Ramos, pelas contribuições essenciais dadas à tese na banca de qualificação.

Aos primeiros amigos que fiz em São Paulo e que guardo no meu coração onde estiverem, Gustavo e Andressa.

Aos amigos Dalton, Roberto, Frederico e Daniel, que me permitiram viver em São Paulo com a alegria que apenas um grupo de amigos tão bons pode proporcionar.

À Sociedade de Ensino Universitário do Nordeste - SEUNE, em nome de Lana Palmeira e Cláudia Amaral, pela primeira oportunidade de exercer o magistério, tão decisivo para a busca do doutorado.

À Escola de Direito da Fundação Getulio Vargas - FGV, em primeiro lugar em nome do Núcleo de Estudos Fiscais, que possibilitou o estágio em pesquisa em direito pelo período de dois anos, fundamentais para a minha formação como pesquisador; em segundo lugar, ao GVlaw, que me proporcionou o exercício do magistério em São Paulo.

Ao Professor Eurico Marcos Diniz de Santi, serei eternamente grato pelo convívio e orientação nesses dois anos de pesquisa no Núcleo de Estudos Fiscais.

Ao Professor Gabriel Ivo, orientador na graduação, no mestrado e para toda a vida, a quem me referi nos agradecimentos da dissertação e, repito, meu pai no direito, a quem devo respeito, admiração e todas as reverências que possam ser dadas. 
À Universidade Federal de Alagoas - UFAL, que também com financiamento público possibilitou meus estudos de graduação e mestrado, não só requisitos formais para o ingresso no doutorado, mas lugar onde tive minha formação e em que me sinto em casa.

À querida Professora Erinalva, por ter despertado o interesse pela filosofia e pela enorme e útil indicação bibliográfica para esta tese.

Ao também querido Sidney Wanderley, que fez a revisão gramatical deste trabalho, como havia feito de minha dissertação, sempre alegre, esclarecedor e absolutamente competente em seu trabalho.

Aos meus amigos de Alagoas que ganharam o mundo e que de uma forma ou de outra contribuíram com suas conversas, indicações, e com a própria amizade, para que eu tivesse a felicidade de escrever: Bruno Emanuel, André Sampaio, Thomé, Manoel B., Afrânio, Maria Clara, Celso e Felipe Ivo.

À minha irmã, Sofia, meu cunhado, Bruno, tios e tias, primos e primas, o meu obrigado por fazerem a minha vida mais feliz.

Em especial aos meus pais, Georges e Ana Eliza, pelo amor que nos une e, não poderia deixar de ressaltar, pelo financiamento privado que despertou em mim um interesse pelos estudos a que muitos não podem ter acesso no nosso país.

At last but not least, gostaria de declarar meu amor à Cecília, companheira de vida conjugal e acadêmica, que prova as minhas receitas na cozinha, revisa os meus textos e inclusive toda esta tese, e a quem dedico meu esforço, alegria e vitórias. 
Minha pátria não é a língua portuguesa.

Nenhuma língua é a pátria.

Minha pátria é a terra mole e peganhenta onde nasci e o vento que sopra em Maceió.

(Lêdo Ivo, Minha Pátria)

O ter curiosidade pelo saber implica o desejo de aprender e, consequentemente, aquilo que temos curiosidade de saber é desejável; quanto ao aprender, quando o fazemos, somos transportados para nossa própria condição natural.

(Aristóteles, Retórica) 


\section{RESUMO}

A hipótese do trabalho é a de que o Supremo Tribunal Federal utiliza argumentos consequencialistas para admitir e julgar o controle de constitucionalidade de leis e normas orçamentárias. A tese é dividida em duas partes. Na primeira são tratados os temas que fundam a análise argumentativa das decisões judiciais. A argumentação jurídica é proposta como lente de exame das decisões judiciais, especialmente o ramo da retórica. De acordo com esse referencial teórico, os tribunais e juízes buscam convencer o auditório de que produzem a decisão mais adequada possível. É ressaltada a importância do argumento na formação do precedente, no que há de fundamental nas decisões (ratio decidendi) e no que é periférico (obiter dictum). O argumento consequencialista é visto diante de diversas teorias que o propõem, como o utilitarismo e o pragmatismo, com destaque, em capítulo próprio, para a teoria de Neil MacCormick, que propõe um consequencialismo essencialmente jurídico. Em sua segunda parte, a tese explora os temas que levarão às conclusões da hipótese. Em primeiro lugar, as características marcantes da produção de leis e normas orçamentárias, sua natureza jurídica e seu fundamento de validade. É revisto o controle de constitucionalidade dessas normas no ordenamento brasileiro, sendo pontuadas as particularidades e limites pertinentes ao seu controle principal. E por fim, no último capítulo, são analisadas pormenorizadamente as decisões que o Supremo Tribunal Federal produziu no controle principal de leis e normas orçamentárias, demarcando a presença de argumentos consequencialistas e buscando estabelecer quais são os precedentes vigentes no direito brasileiro. Ao fim, conclui-se que o controle de constitucionalidade principal é a via mais adequada nas matérias orçamentárias; que o precedente estabelecido no Supremo Tribunal Federal é o de possibilidade de controle de constitucionalidade principal de normas orçamentárias por $\mathrm{ADI}$ e $\mathrm{ADO}$, não por $\mathrm{ADPF}$; e que o tribunal usa adequadamente, na maioria das vezes, os argumentos consequencialistas, porquanto estes predominam (ratio decidendi) nas decisões mais importantes sobre a matéria.

Palavras-chave: Consequencialismo - Argumentação Jurídica - Leis Orçamentárias Orçamento Público - Controle de Constitucionalidade 


\begin{abstract}
The hypothesis of this work is that the Supreme Court uses consequentialist arguments to admit the judicial review of budgetary laws. The thesis is divided in two parts. In the first, the themes that underlie the argumentative analysis of judicial decisions are discussed. Legal argumentation is proposed as a lens for examining decisions, especially rhetoric. According to this theoretical framework, the courts and judges seek to convince the audience that they produce the most appropriate decisions possible. It highlights the significance of the argument in shaping the precedent, in what is crucial in decisions (ratio decidendi), and what is peripheral (obiter dictum). The consequentialist argument is analyzed according to the various theories that underlie it, such as utilitarianism and pragmatism, especially, in a separate chapter, according to Neil MacCormick's theory, that offers an essentially legal consequentialism. In its second part, the thesis explores the issues that lead to the conclusions of the hypothesis. Firstly, the salient features of the production of budget laws, its legal status and fundament of validity. The judicial review of these laws in the Brazilian legal system is revised, and the limits and particularities of its "main" control are punctuated. And finally, in the last chapter, the decisions produced by the Supreme Court in the "main" judicial review of budgetary laws are minutely explored, the existence of consequentialist arguments is indicated, and it seeks to establish the precedents existing in Brazilian law. It concludes, lastly, that the abstract judicial review is the most suitable option in budget matters; that the precedent set in the Supreme Court is about the possibility of the abstract judicial review of budgetary laws by "ADI" and "ADO", but not "ADPF"; and that the court properly uses, most often, consequentialist arguments, and they predominate (ratio decidendi) in the most important decisions about it.
\end{abstract}

Key words: Consequentialism - Legal Argumentation - Budgetary Laws - Public Budget - Judicial Review 


\section{RIASSUNTO}

L'ipotesi di questo lavoro è che la Suprema Corte Federale del Brasile usa argomenti consequenzialisti ad ammettere la costituzionalità delle leggi e delle disposizioni di bilancio. La tesi è divisa in due parti. La prima è dato a temi che sono alla base dell'analisi argomentativa delle decisioni giudiziarie. L'argomentazione giuridica si propone come una lente per l'esame di sentenze, in particolare il ramo della retorica giuridica. Secondo questo quadro teorico, i tribunali ed i gíudici cercano di convincere il pubblico che producono la decisione più appropriata possibile. Ha sottolineato l'importanza della formazione nella discussione precedente, in quello che è cruciale nelle decisioni (ratio decidendi) e ciò che è periferico (obiter dictum). L'argomento consequenzialista è visto sulle varie teorie che si propongono, come l'utilitarismo e pragmatismo, soprattutto, in un capitolo specifico, alla teoria di Neil MacCormick, che ha proposto un consequenzialismo essenzialmente giuridico. Nella seconda parte, la tesi esplora le questioni che portano alle conclusioni dell'ipotesi . In primo luogo, le caratteristiche salienti delle leggi di bilancio di produzione e dei regolamenti, suo status giuridico e il fondamento di validità delle sue norme. Esaminiamo il controllo di costituzionalità di tali norme nel sistema giuridico brasiliano, e punteggiati i limiti e le peculiarità rispetto al suo controllo principale. E, infine, nell'ultimo capitolo vengono esplorate in dettaglio le decisioni che la Corte Suprema ha dato alle leggi di controllo principali e norme di bilancio, che segnano la presenza di argomenti consequenzialisti e cercando di stabilire quali sono i precedenti esistenti nel diritto brasiliano. Conclude, infine, che il controllo principale di costituzionalità è il più appropriato per controllare la costituzionalità delle leggi e delle disposizioni di bilancio, il precedente stabilito dalla Corte Suprema è la possibilità di controllo delle principali regole di bilancio di costituzionalità per ADI e ADO, non per ADPF, e che la Corte ha usato correttamente, il più delle volte, gli argomenti consequenzialisti, ed essi predominano (ratio decidendi) nelle decisioni più importanti in materia.

Parole chiave: Consequenzialismo - Argomentazione Giuridici - Leggi di Bilancio Bilancio Pubblico - Sindacato Giurisdizionale 


\section{LISTA DE ABREVIATURAS E SIGLAS}

ACERP - Associação de Comunicação Educativa Roquete Pinto

ACE - Argumentos Consequencialistas Extrajurídicos

ACJ - Argumentos Consequencialistas Jurídicos

AD - Argumentos Deontológicos

ADC / ADECON - Ação Declaratória de Constitucionalidade

ADCT - Ato das Disposições Constitucionais Transitórias

ADI / ADIn - Ação Direta de Inconstitucionalidade

ADO - Ação Direta de Inconstitucionalidade por Omissão

ADPF - Ação de Descumprimento de Preceito Fundamental

AgRg - Agravo Regimental

AGU - Advocacia-Geral da União

$\mathrm{C}-$ Conclusão

CF - Constituição Federal

CIDE - Contribuição de Intervenção no Domínio Econômico

CNT - Confederação Nacional do Transporte

CPMF - Contribuição Provisória sobre a Movimentação ou Transmissão de Valores e de

Créditos e Direitos de Natureza Financeira

DEM - Democratas (Partido)

DNIT - Departamento Nacional de Infraestrutura de Transportes

FAT - Fundo de Amparo ao Trabalhador

FPE - Fundo de Participação dos Estados

LDO - Lei de Diretrizes Orçamentárias

LRF - Lei de Responsabilidade Fiscal

LOA - Lei Orçamentária Anual

MC - Medida Cautelar

MP - Medida Provisória

$\mathrm{O}$ - Obrigatório

OAB - Ordem dos Advogados do Brasil

OCDE - Organização para a Cooperação e Desenvolvimento Econômico

$\mathrm{P}$ - Permitido

PM - Premissa Maior 
Pm - Premissa Menor

PPA - Plano Plurianual

PSDB - Partido da Social Democracia Brasileira

RE - Recurso Extraordinário

RISTF - Regimento Interno do Supremo Tribunal Federal

STF - Supremo Tribunal Federal

V - Proibido 


\section{SUMÁRIO}

Introdução.

PRIMEIRA PARTE: Uso de Argumentos Baseados em Consequências nas Decisões Judiciais

Capítulo 1. Decisão Judicial, Argumentação Jurídica e Retórica.

1.1 Decisão judicial e argumentação jurídica. .18

1.2 Retórica como análise da decisão judicial. .21

1.3 Separação dos Poderes: do self restraint ao ativismo judicial. .29

1.4 Obiter dictum e ratio decidendi: que argumentos formam o precedente?

Capítulo 2. Teorias Consequencialistas e o Direito

2.1 Que é consequencialismo? .40

2.2 Consequencialismo na filosofia moral. .45

2.3 Consequencialismo na tradição utilitarista. . .46

2.4 Consequencialismo no pragmatismo e na análise econômica do direito .49

2.5 Consequencialismo e direito. .55

Capítulo 3. Retórica e o Consequencialismo Jurídico na Teoria de Neil MacCormick.

3.1 Retórica e argumentação jurídica em MacCormick .61

3.2 Regra de reconhecimento, o silogismo jurídico e a argumentação dedutiva..................67

3.3 Universalização das decisões em MacCormick........................................................... 70

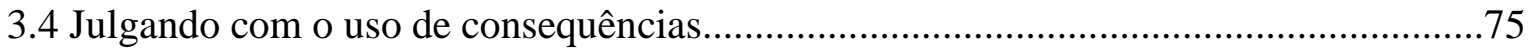

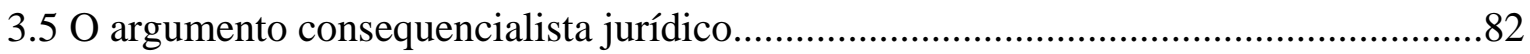


SEGUNDA PARTE: Consequencialismo no Controle de Constitucionalidade de Leis e Normas Orçamentárias no Brasil

1.1. Conteúdo e disposição das leis e normas orçamentárias .............................................90

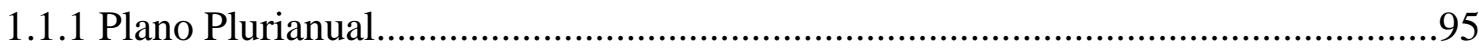

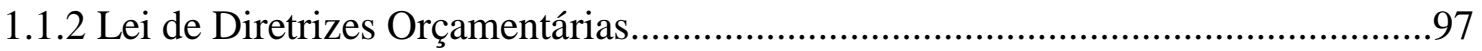

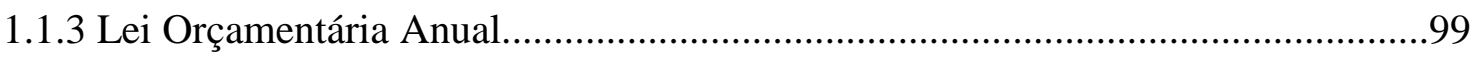

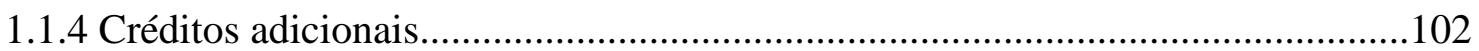

1.1.5 Medida Provisória em matéria orçamentária........................................................104

1.2 Natureza jurídica das leis orçamentárias no Brasil: ainda é possível falar em leis de efeitos concretos?

1.3 Qual o fundamento de validade das leis orçamentárias?

Capítulo 2. Controle de Constitucionalidade das Leis e Normas Orçamentárias no Brasil.....

2.1 Controle de constitucionalidade no Brasil: características e limites.

2.2 Eficácia das decisões do Supremo Tribunal Federal e modulação de efeitos no controle principal.

2.3 Instrumentos processuais do controle de constitucionalidade principal das leis e normas orçamentárias no Brasil.

2.3.1 ADI, ADC e ADO: o controle de constitucionalidade de leis e atos normativos.

2.3.2 ADPF

2.4 Controle de constitucionalidade de leis e normas orçamentárias

Capítulo 3. Análise das Decisões no Controle de Constitucionalidade Principal de Leis e Normas Orçamentárias no Brasil: o precedente estabelecido no Supremo Tribunal Federal e as conclusões sobre o uso de argumentos consequencialistas. 
3.2 Análise das decisões proferidas no controle principal de leis e normas orçamentárias.

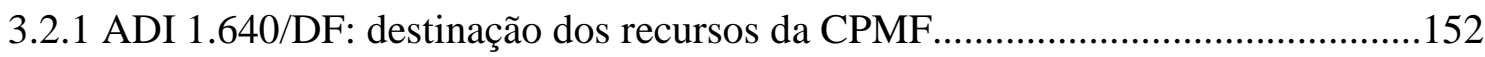

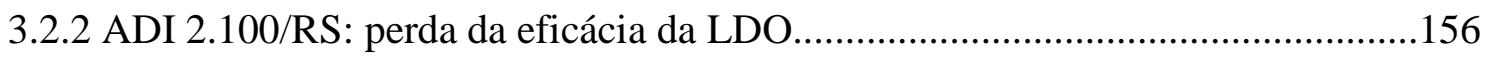

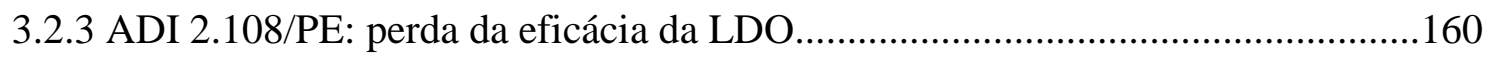

3.2.4 ADI 2.535/MT: norma na LDO sobre precatórios.............................................164

3.2.5 ADI 2.925/DF: destinação dos recursos da CIDE.............................................167

3.2.6 ADI 4.048/DF: crédito extraordinário por Medida Provisória............................179

3.2.7 ADI 4.049/DF: crédito extraordinário por Medida Provisória.............................194

3.2.8 ADI 4.904/DF: crédito extraordinário por Medida Provisória.............................200

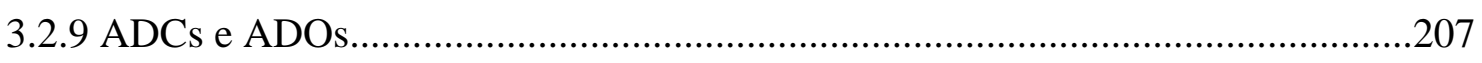

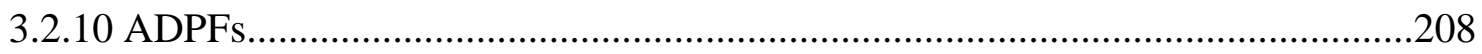

3.3 Qual o precedente estabelecido pelo Supremo Tribunal Federal no controle de

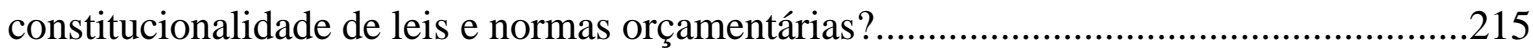

3.4 Conclusões sobre o impacto dos argumentos consequencialistas nas decisões do controle de constitucionalidade de leis e normas orçamentárias no Brasil.

Conclusões.

Referências 


\section{INTRODUÇÃO}

As leis orçamentárias são os instrumentos jurídicos mais importantes depois da Constituição Federal. Todas as conquistas sociais, e mesmo os direitos chamados de $1^{\mathrm{a}}$ geração dispostos pela Constituição, apenas são efetivamente prestados pelo Estado quando constantes das leis orçamentárias. De nada adianta, portanto, garantir o direito universal à saúde se o orçamento público não destina as receitas necessárias à satisfação dessa política.

O jurista Alfredo Augusto Becker, no clássico “Teoria Geral do Direito Tributário", chega a dizer que se o Estado escolhe aprovar orçamentos periódicos, a sua Constituição se daria por períodos determinados, ou seja, os períodos orçamentários. ${ }^{1} \mathrm{O}$ orçamento, portanto, conduz ou deve conduzir toda a ação estatal, planejando as políticas públicas e a prestação de serviços públicos.

Cada vez mais, o Direito Financeiro, disciplina que estuda o fenômeno orçamentário, e seus instrumentos ganham importância no cenário atual brasileiro. Estabilidade econômica, desenvolvimento social, manifestações populares por mais transparência e melhoria dos direitos sociais. Todos esses debates, fundamentais para o país, passam pela discussão orçamentária.

Dada a importância e o protagonismo do orçamento público, surgem reflexões acerca do controle da validade das normas dessa natureza. Se o Estado se constitui periodicamente pela lei orçamentária, uma inconstitucionalidade presente nessa lei, ainda que periódica, é extremamente grave.

O controle de constitucionalidade, sistema desenvolvido para proteger a supremacia da Constituição, é essencial para averiguar a correta produção de leis orçamentárias.

No Brasil há um sistema de controle de constitucionalidade onde qualquer juiz pode declarar a inconstitucionalidade de uma lei, que se divide em dois tipos: o principal, no qual as normas são questionadas abstratamente, e o incidental, em que as normas são vistas num processo subjetivo e relacionadas a um caso concreto.

No controle principal, o Supremo Tribunal Federal detém a competência para julgar a constitucionalidade das leis orçamentárias federais e estaduais face à Constituição

\footnotetext{
${ }^{1}$ BECKER, Alfredo Augusto. Teoria Geral do Direito Tributário. $3^{\text {a }}$ ed. São Paulo: Lejus, 1998, p. 231.
} 
Federal, e por isso a sua análise se torna fundamental para entender qual o controle efetivamente exercido sobre tais normas, quais são os limites de sua realização etc.

O objeto de estudo da tese não será apenas o controle de constitucionalidade de leis orçamentárias, mas o de normas orçamentárias. Tal ampliação se deve ao fato de que várias decisões proferidas sobre a matéria são relativas a modificações feitas às leis orçamentárias, muitas vezes por decreto, ou, especialmente, medidas provisórias. Como as medidas provisórias não são exatamente leis, embora produzam efeitos semelhantes, como será visto em tópico específico, prefere-se a expressão normas orçamentárias.

Ademais, o termo normas parece mais adequado por outro motivo, utilizandose a difundida distinção entre texto e norma. Nesse caso, de lei e norma. Isto é, as normas não se confundem com os textos de lei ou da decisão judicial, são unidades de sentido construídas pelo intérprete diante do suporte material. Por isso, os objetos da análise serão as normas presentes ou veiculadas por leis orçamentárias e outros instrumentos normativos.

A diferenciação é relevante na medida em que se observará, em algumas decisões analisadas, a confusão entre uma lei orçamentária específica e as normas que por ela são veiculadas, chamando-as de "leis de efeitos concretos". Por isso deve-se separar o instrumento introdutor de normas das normas introduzidas por ele no ordenamento jurídico.

Mas o estudo que será feito das decisões proferidas pelo Supremo Tribunal Federal no controle de normas orçamentárias terá uma abordagem específica, a saber, o consequencialismo jurídico.

O uso de argumentos consequencialistas será analisado nas decisões proferidas no controle de constitucionalidade de normas orçamentárias, buscando-se entender qual o mecanismo que conduz as argumentações do Supremo Tribunal Federal brasileiro nessas decisões.

É preciso ressaltar, no entanto, mais um corte feito nesta tese e que é essencial para possibilitar o estudo de seu objeto: o de se ater ao controle de constitucionalidade principal de normas orçamentárias. O objetivo é entender o tipo de argumentação produzida nas ações onde as leis e normas orçamentárias são abstratamente consideradas, sem abordar o direito subjetivo de partes à determinadas tutelas.

Para tratar do tema, foi o presente trabalho dividido em duas partes. A primeira expõe o referencial teórico da tese sobre o consequencialismo, que fundamentará a análise 
das decisões judiciais sobre o tema, sob a lente da retórica como ramo da argumentação jurídica.

Essa escolha implica que as decisões não serão analisadas com instrumentos silogísticos clássicos, senão com a construção de argumentos sob a forma de entimemas, em que várias premissas contribuem não uniformemente para a formação da razão decisória.

Num segundo momento, serão vistas as teorias que tratam do consequencialismo, especialmente no direito, como razão possível para decidir, especialmente nos paradigmas do utilitarismo, pragmatismo jurídico e análise econômica do direito. Esses referenciais secundários servirão de base para confrontar e entender o consequencialismo jurídico de Neil MacCormick, estudado em momento seguinte.

O consequencialismo proposto pelo jurista escocês, apesar de limitado, por propor um conceito restrito de consequencialismo aceitável, é extremamente útil porque põe linhas mais claras sobre que tipo de argumentação acerca das consequências é aceitável para o direito.

Finda a primeira parte, o trabalho segue apresentando as características das leis orçamentárias, expondo suas principais características, e as noções de natureza jurídica e fundamento de validade, necessárias ao entendimento do controle de constitucionalidade.

Em seguida, serão trabalhadas as noções essenciais do controle de constitucionalidade de normas orçamentárias dentro do sistema positivo brasileiro, fixando-se os conceitos necessários à compreensão dos limites dos controles principal e incidental no contexto do controle difuso que vigora no Brasil.

Por fim, serão analisadas as principais decisões proferidas no controle de constitucionalidade principal de leis e normas orçamentárias pelo Supremo Tribunal Federal, órgão que detém a competência para decidir sobre tais questões. Com destaque maior para as Ações Diretas de Inconstitucionalidade - ADI, que vêm sendo decididas desde a Constituição de 1988, e serão selecionadas pela sua importância para o tema e pela formação dos precedentes, alimentados pelas próprias decisões que se autorreferem.

Diante dessas definições, a tese formula duas principais hipóteses. Em primeiro lugar, que o precedente fixado hoje no Supremo Tribunal Federal no Brasil para conhecer ações do controle de constitucionalidade principal de leis e normas orçamentárias é o da ADI 4.048. Nesse contexto, ações no controle principal que tenham objeto leis e normas orçamentárias devem ser conhecidas e julgadas, independentemente do caráter geral ou abstrato de suas normas. 
E a segunda, ponto central da tese, é a proeminência de argumentos de natureza consequencialista em tais decisões. Que existem argumentos dessa natureza; constituem o núcleo central da razão decisória (ratio decidendi) em muitos casos; e que em outros estão presentes, mesmo sem contribuir decisivamente para a decisão (obiter dictum). ${ }^{2}$

\footnotetext{
${ }^{2}$ Por fim, as citações diretas, entre aspas ou com recuo, quando maiores que três linhas, e sempre que apresentarem grifos, serão os presentes no texto original. Quando excepcionalmente o grifo tiver sido acrescido ao texto, ele trará a indicação "grifo nosso".
} 


\section{PRIMEIRA PARTE: USO DE ARGUMENTOS BASEADOS EM CONSEQUÊNCIAS NAS DECISÕES JUDICIAIS}

\section{DECISÃO JUDICIAL, ARGUMENTAÇÃO JURÍDICA E RETÓRICA}

1.1 Decisão judicial e argumentação jurídica

1.2 Retórica como análise da decisão judicial

1.3 Separação dos Poderes: do self restraint ao ativismo judicial

1.4 Obiter dictum e ratio decidendi: que argumentos formam o precedente?

\subsection{Decisão judicial e argumentação jurídica}

O objeto desta tese é o estudo das decisões judiciais proferidas pelo Supremo Tribunal Federal no controle de constitucionalidade de leis e normas orçamentárias. O método de análise será o da argumentação jurídica. Daí este tópico ser essencial para estabelecer os fundamentos que irão orientar a leitura do trabalho.

Há hoje um consenso amplo sobre a argumentação jurídica de que modelos simples são insuficientes. ${ }^{3}$ É preciso, portanto, observar a complexidade do fenômeno argumentativo no direito, para elaborar uma teoria não exauriente, mas satisfatória, intentando explicar e orientar o jurista na sua atividade.

Manuel Atienza explora as razões para que as teorias da argumentação jurídica tenham seu interesse ampliado exponencialmente nos últimos anos: i) as teorias do direito até o século XX teriam se descuidado desse aspecto, explorando apenas outros pontos de vista do fenômeno jurídico; ii) a prática do direito constitucional exigiria cada vez mais essa dimensão argumentativa, uma vez que as constituições atuais deixariam maiores espaços que seriam preenchidos pela argumentação; iii) haveria uma demanda por fundamentação e argumentação dos órgãos públicos, uma vez que em regimes democráticos os órgãos públicos seriam mais exigidos nesse sentido; iv) um ensino do direito mais prático estaria voltado para o manejo essencialmente argumentativo do material jurídico; além da v) perda da importância da autoridade e a necessidade de consentimento dos afetados para a legitimação do poder. ${ }^{4}$

\footnotetext{
${ }^{3}$ ALEXY, Robert. Direito, Razão, Discurso: estudos para a filosofia do direito. Luís Afonso Heck (Trad.). Porto Alegre: Livraria do Advogado, 2010, p. 77.

${ }^{4}$ ATIENZA, Manuel. Curso de Argumentación Jurídica. Madrid: Editorial Trotta, 2013, p. 21.
} 
Podemos aferir da passagem citada que a argumentação jurídica cresce no contexto brasileiro atual, onde a demanda por decisões públicas vem acompanhada pela necessidade de maior e melhor fundamentação dos atos praticados pela administração pública, seja no âmbito judicial ou administrativo. O raciocínio é o de que, quanto mais democracia, maior a demanda por argumentos que justifiquem as decisões de poder.

Há, para explicar tal fenômeno, diversas teorias da argumentação que foram produzidas no âmbito jurídico, e há diversas técnicas argumentativas que podem ser utilizadas e analisadas pelas teorias da argumentação. ${ }^{5}$ Robert Alexy distingue de forma mais ampla os seguintes tipos de discursos jurídicos: a) ciência jurídica (legal science or legal dogmatics); b) deliberação judicial (judicial deliberation); c) debates judiciais (debates in courts of law); d) tratamento legislativo de questões jurídicas (legislative treatment of legal questions); e) discussão de questões jurídicas entre "operadores do direito" (discussions of legal questions among students or among jurists or lawyers or among legally qualified personnel in administration or industry); e f) debates de problemas jurídicos na mídia etc. ${ }^{6}$

Segundo classificação de Manuel Atienza, o estudo da argumentação jurídica ocorre em três campos distintos do direito: i) na produção e estabelecimento de normas jurídicas, nas fases pré-legislativa e legislativa em si; ii) na aplicação das normas jurídicas; e iii) na dogmática jurídica, quando se ocupa de casos abstratos. ${ }^{7}$

Este trabalho produzirá argumentação jurídica no campo da dogmática, mas tendo como objeto o segundo campo na classificação de Atienza, de aplicação das normas jurídicas, sobretudo nos argumentos levantados e utilizados em decisões judiciais em matéria de direito financeiro, qual seja o controle de constitucionalidade de normas e leis orçamentárias. A análise será feita a partir do texto jurídico da decisão judicial, analisando seus argumentos, a construção feita, tomando-a como ponto de partida para a discussão sobre consequencialismo jurídico no Brasil.

Trata, ainda, do segundo tipo de discurso jurídico da classificação de Robert Alexy, da deliberação judicial, por meio do primeiro discurso, que é o da ciência,

\footnotetext{
${ }^{5}$ Para conhecer melhor tais técnicas, consultar: PERELMAN, Chaim \& OLBRECHTS-TYTECA, Lucie. Tratado da Argumentação: a nova retórica. Maria Ermantina de Almeida Prado Galvão (Trad.). São Paulo: Martins Fontes, 2005; e FERRAZ JR., Tércio. Introdução ao Estudo do Direito: técnica, decisão e dominação. $3^{\mathrm{a}}$ ed. São Paulo: Atlas, 2001.

${ }^{6}$ ALEXY, Robert. A Theory of Legal Argumentation: the theory of rational discourse as theory of legal justification. OXFORD: Oxford University Press, 2010, p. 211.

7 ATIENZA, Manuel. As Razões do Direito: teorias da argumentação jurídica. Trad. Maria Cristina G. Cupertino. São Paulo: Landy Editora, 2006, p 18.
} 
analisando o discurso de um tribunal sobre questão específica, a saber, o controle de constitucionalidade das leis e normas orçamentárias.

Mas falar de argumentação jurídica não tem sentido sem que se tenha uma definição de argumento. A palavra argumento tem origem a mesma origem da palavra argentum, que em latim significa prata. A prata é um objeto brilhante, que, quando na presença de luz, reflete-a iluminando o ambiente. O argumento é uma formulação linguística que busca iluminar uma tese ou asserção. Argumentar, portanto, não é afirmar simplesmente algo, mas apoiar uma tese com fundamentos ou justificações.

Toulmin diz que a função primária do argumento seria justificatória, isto é, justificar uma alegação ou asserção. Asserção ou alegação seria uma tese proposta. E “um homem que faz uma asserção, faz também um pedido - pede que lhe demos atenção ou que acreditemos no que afirma". ${ }^{8}$ A alegação no direito é fundamental. Alega-se ser o tributo inconstitucional. Faz-se uma asserção de que a lei orçamentária não cumpriu um determinado dispositivo constitucional. Para tais alegações, é preciso recorrer a argumentos.

Ao se afirmar algo, precisa-se de argumentos que iluminem essa afirmação, confirmando-a pela interpretação de fatos e dados, pela exposição de razões, convencendo que a alegação é verdadeira, válida, possível, razoável.

Uma última distinção útil à melhor compreensão do objetivo da tese é entre razões explicativas e razões justificadoras. ${ }^{9}$ As razões explicativas são aquelas independentes da fundamentação da decisão e que explicam por diversos aspectos extrajurídicos os motivos pelos quais os juízes decidiram de determinada forma. Como, por exemplo, a razão explicativa para que o Ministro $\mathrm{X}$ tenha decidido a favor do governo naquele processo seria a anterior vinculação ao mesmo governo no exercício do cargo público Y.

A decisão judicial estudada do ponto de vista econômico ou histórico pode levar a conclusões cientificamente válidas e interessantes ao estudo do direito. No entanto, a abordagem aqui feita será exatamente a das razões justificadoras, ligadas às razões que são efetivamente trazidas à decisão, e que servem de fundamento para justificá-la. As razões justificadoras podem não exatamente explicar a realidade de como a decisão foi

\footnotetext{
${ }^{8}$ TOULMIN, Stephen E. Os Usos do Argumento. São Paulo: Martins Fontes, 2006, p. 15 a 17.

9 "Dizer que o juiz tomou essa decisão devido às suas fortes crenças religiosas significa enunciar uma razão explicativa; dizer que a decisão do juiz se baseou numa determinada interpretação do artigo 15 da Constituição significa enunciar uma razão justificadora". ATIENZA, Manuel. As Razões do Direito: teorias da argumentação jurídica. Trad. Maria Cristina G. Cupertino. São Paulo: Landy Editora, 2006, p. 20.
} 
feita ou tomada, mas são as razões expostas pelo juiz na própria decisão e que podem, assim, ser analisadas do ponto de vista jurídico.

Além da fixação do método da argumentação jurídica como o adequado para entender as razões justificadoras nas decisões objeto desta tese, ainda é preciso estabelecer, dentro da argumentação, qual o tipo de teoria que será utilizada. A retórica, enquanto técnica de análise do ramo da argumentação jurídica, parece ser o método mais adequado para o fim a que se propõe, pelos motivos que serão expostos no tópico seguinte.

\subsection{Retórica como análise da decisão judicial}

Pode-se inserir modernamente a retórica no campo do estudo das teorias da argumentação. Neste tópico serão vistos os fundamentos da retórica clássica e contemporânea como sustentação do uso da retórica como método de análise de argumentos consequencialistas nas decisões do controle de constitucionalidade de normas orçamentárias.

A retórica é estudada desde os gregos até os tempos atuais, mas o senso comum sobre seu uso, que normalmente a associa a argumentos falaciosos, falsos, enganosos, dificulta a real noção sobre sua utilidade na filosofia e até no direito. A ideia deste subtópico é estabelecer as bases teóricas da retórica para entender a teoria de Neil MacCormick e, consequentemente, sua aplicação no uso de consequências jurídicas.

Segundo Aristóteles, a retórica consistiria na faculdade de se observar, em cada caso, o que é apto para persuadir. ${ }^{10}$ A análise nesse campo, portanto, seria adequada a textos que visam à persuasão ou ao convencimento de um determinado auditório. $\mathrm{O}$ objetivo da retórica, pois, é estudar discursos que tenham por objetivo o convencimento ou a persuasão. Os discursos jurídicos, nesse sentido, são discursos cujo objetivo primordial é persuadir que sua tese é a que expõe a norma válida sobre o caso.

De acordo com Reboul, retórica é a arte de persuadir pelo discurso, e "por discurso entendemos toda produção verbal, escrita ou oral, constituída por uma frase, ou por uma sequência de frases, que tenha começo e fim e apresente certa unidade de sentido". ${ }^{11}$ Não é qualquer discurso que pode ser analisado sob o ponto de vista da retórica,

\footnotetext{
${ }^{10}$ ARISTÓTELES. Retórica. Trad. Edson Bini. São Paulo: Edipro, 2011, p. 44.

${ }^{11}$ REBOUL, Olivier. Introdução à Retórica. São Paulo, Martins Fontes, 2004, p. XIV.
} 
isto é, a retórica não seria aplicável a todos os discursos, mas somente àqueles que visam a persuadir. ${ }^{12} \mathrm{O}$ discurso poético, por exemplo, a priori não é, ou melhor, não tem carga persuasiva. Os discursos jurídicos, falando amplamente, carregam forte carga persuasiva, visto que pretendem convencer alguém de que aquela seja a melhor tese sobre o tema.

Desde o início, a retórica nasceu com um viés jurídico. ${ }^{13}$ Segundo Michel Meyer, os primeiros advogados da retórica teriam sido os intelectuais chamados de sofistas, que professavam o emprego da sabedoria para intervir em favor do destino das vítimas espoliadas, passando a empregar a técnica para todas as causas, o que teria sido reprovado por Platão. ${ }^{14}$

A retórica, então, sempre gozou de má reputação, que se deve ao tratamento a ela dispensado pelos principais filósofos gregos, notadamente Sócrates e Platão. Um dos primeiros livros de Platão, "Protágoras", traz a discussão entre o sofista que dá nome ao livro e Sócrates, quando Hipócrates, um jovem, pretende que Protágoras o ensine a aretê, traduzida também como virtude ou excelência na arte política, enquanto Sócrates duvida que tal arte possa ser ensinada. Para Marina MacCoy, Platão em "Protágoras" não rejeita completamente a retórica; o pensador estaria "mais interessado em redefinir o sentido da tradição retórica tendo em vista os objetivos da filosofia do que em sua rejeição maciça". ${ }^{15}$

Para Alexandre Koyré, Sócrates não ignora a existência da retórica, apenas nega o seu valor. ${ }^{16} \mathrm{E}$ talvez a pretensão da retórica não seja exatamente precondicionar algum valor ao discurso analisado.

A retórica é discutida no contexto da Grécia como uma arte de persuadir independentemente de valores e que, por isso, seria menor do que a filosofia, esta sim preocupada com o objeto da discussão.

Em contribuição moderna sobre o tema, afirma Reboul sobre a retórica:

Esta, dizíamos, é uma arte. Este termo, tradução do grego techné, é ambíguo, e até duplamente ambíguo. Em primeiro lugar, porque designa tanto uma habilidade espontânea quanto uma competência adquirida através do ensino. Depois, porque designa ora uma simples técnica, ora, ao contrário, o que na criação ultrapassa a técnica e pertence somente ao

\footnotetext{
${ }^{12}$ Idem, Ibdem.

${ }^{13}$ Questionando a retórica como ramo da filosofia, João Maurício Adeodato afirma que: "Se filosofia é a busca pela verdade, a retórica prescinde desse conceito e, assim, não está dentro da filosofia”. ADEODATO, João Maurício. A Retórica Constitucional: sobre tolerância, direitos humanos e outros fundamentos éticos do direito positivo. São Paulo, Saraiva, 2010, p. 47.

${ }^{14}$ MEYER, Michel. A Retórica. São Paulo: Ática, 2007, p. 19.

${ }^{15}$ McCOY, Marina. Platão e a Retórica de Filósofos e Sofistas. Trad. Lívia Oushiro. São Paulo, Madras, 2010 , p. 69.

${ }^{16}$ KOYRÉ, Alexandre. Introdução à Leitura de Platão. Lisboa, Editorial Presença, 1988, p. 31.
} 
"gênio" do criador. Em qual ou em quais desses sentidos se está pensando quando se diz que a retórica é uma arte? Em todos. ${ }^{17}$

Lendo Reboul, é possível pensar que talvez Protágoras e Sócrates estivessem certos dentro de seus referenciais teóricos, pois enquanto o primeiro reduzia a atividade política à habilidade retórica, o segundo a preenchia de valores e carregava de sentido.

A retórica, segundo Reboul, seria invenção grega, pois este povo teria inventado a "técnica retórica", como ensinamento distinto, independente dos conteúdos, o que possibilitava defender qualquer causa ou tese. ${ }^{18}$ Nesse sentido, a arte de Protágoras claramente se amolda ao conceito apresentado de retórica.

Esta arte não teria nascido em Atenas, mas na Sicília dominada pelos gregos, por volta de 465 a.C, onde:

Certo Córax, discípulo do filósofo Empédocles, e o seu próprio discípulo, Tísias, publicaram então uma "arte oratória" (tekhné rhetoriké), coletânea de preceitos práticos que continha exemplos para uso das pessoas que recorressem à justiça. Ademais, Córax dá a primeira definição de retórica: ela é "criadora de persuasão". ${ }^{19}$

E não é coincidência que democracia e retórica tenham nascido na mesma região e época, pois, segundo Perelman, a retórica é indispensável numa concepção menos autoritária e mais democrática do direito, conforme a ideia de que o direito não deve ser apenas obedecido, mas também reconhecido. Tanto que será mais bem observado e cumprido quanto mais largamente for aceito. ${ }^{20}$

Michel Meyer traz uma classificação de retórica em três tipos, demonstrados pelas seguintes definições:

(1) Retórica é uma manipulação do auditório (Platão);

(2) Retórica é a arte do bem falar (ars bene dicendi, de Quintiliano);

(3) Retórica é a exposição de argumentos ou de discursos que devem ou visam persuadir (Aristóteles). ${ }^{21}$

Os três tipos expostos por Meyer são exaustivos, porquanto contêm uma visão pessimista da retórica, como mera manipulação, típica dos primeiros filósofos gregos;

\footnotetext{
${ }^{17}$ REBOUL, Olivier. Introdução à Retórica. São Paulo, Martins Fontes, 2004, p. XVI.

${ }^{18}$ Idem, p. 1.

${ }^{19}$ Idem, p. 2.

${ }^{20}$ PERELMAN, Chaïm. Ética e Direito. $2^{a}$ ed. Trad. Maria Ermantina de A. P. Galvão. São Paulo, 2005, p. 554.

${ }^{21}$ MEYER, Michel. A Retórica. São Paulo: Ática, 2007, p. 21.
} 
outra otimista, em que a técnica ou arte retórica ensinaria a falar ou discursar bem; e a terceira, que poderia ser considerada realista, observando a retórica apenas como exposição de argumentos com o fim da persuasão ou do convencimento, tanto no contexto da manipulação, quanto no do bem-falar.

No sentido dado por Aristóteles, embora a Retórica não estude os valores e o conteúdo do discurso, apenas a "forma", o orador deve ter esses conhecimentos e se basear em valores para bem exercer essa técnica. Ele se dedicou a escrever um livro sobre a arte retórica, no qual fixou pontos que ainda hoje orientam os estudos sobre o assunto, discorreu sobre os três tipos de discurso: i) o deliberativo, que induz a fazer ou não fazer algo; ii) o forense, que comporta a acusação ou defesa de alguém; iii) e o demonstrativo, que se ocuparia do louvor ou censura de alguém. ${ }^{22}$ Embora essa classificação especificamente pareça ultrapassada, em vários outros conceitos Aristóteles estabeleceu premissas ainda hoje estudadas. Considerados tais discursos de forma mais ampla, ainda é possível explorá-la, revendo seus conceitos para a realidade atual.

De acordo com a concepção de Aristóteles, segundo Giovani Reale, a retórica,

para ser autêntica, não pode ser separada do verdadeiro e do justo, e não pode fundar-se sobre a moção dos sentimentos. O retórico deve conhecer as coisas sobre as quais quer convencer, assim como deve conhecer a alma dos ouvintes na qual deve introduzir a persuasão. Em suma, a verdadeira arte retórica deve pressupor os valores teóricos e morais, e, em última instância, deve fundar-se sobre eles. ${ }^{23}$

Outra distinção fundamental, feita por Perelman, com base em toda a tradição retórica, identifica três elementos do discurso do ponto de vista da retórica: o orador, o assunto e o auditório. $^{24}$

O orador, como emissor do discurso, é elemento central da retórica, pois a capacidade de convencimento de um discurso está alinhada ao perfil que o orador apresenta, inclusive o seu prestígio. No caso do direito, essa noção é ainda mais importante, tendo em vista que a competência para emitir normas é fundamentalmente baseada nessa noção. Aqui, a mais importante técnica no direito é certamente a do argumento de autoridade, não só comum, como autorizado e incentivado pelos sistemas jurídicos, que sempre exigem a citação de grandes doutrinadores, jurisprudências de outros

\footnotetext{
${ }^{22}$ ARISTÓTELES. Retórica. São Paulo: Edipro, 2011, p. 55.

${ }^{23}$ REALE, Giovani. Aristóteles. São Paulo: Edições Loyola, 2007, p. 163.

${ }^{24}$ PERELMAN, Chaim \& OLBRECHTS-TYTECA, Lucie. Tratado da Argumentação: a nova retórica. Maria Ermantina de Almeida Prado Galvão (Trad.). São Paulo: Martins Fontes, 2005.
} 
tribunais que decidiram sobre a matéria, ${ }^{25}$ elevando a autoridade do orador para um nível de aceitação no discurso, embora o seu exagero deva ser identificado e coibido.

Especificamente em relação a esta tese, o conceito de orador parece relevante na medida em que serão analisadas as decisões de um único tribunal, mas de múltiplos componentes, portanto, de um grupo restrito de oradores que possuem um histórico institucional relevante.

$\mathrm{O}$ assunto ou o discurso produzido, que seria a produção linguística em si, sendo o principal aspecto de análise na maioria dos estudos retóricos, será o foco deste trabalho, embora venham a ser feitas considerações sobre o orador e o auditório na análise da decisão.

O último elemento é a quem se dirige o discurso, o auditório. Sendo dois os tipos de auditório: o universal, conceito abstrato idealizado pelo orador, que corresponde ao público ideal a quem o discurso pretende convencer; e o particular, quando o público destinatário da persuasão do discurso é faticamente identificável. ${ }^{26}$ No caso das decisões de um juiz ou tribunal, embora as partes sejam as maiores interessadas, certamente o auditório é universal, pois são formuladas para um público maior e indistinto, não identificável, mesmo em casos concretos com efeitos restritos a essas mesmas partes. Perelman afirma que no caso do advogado, a pessoa a quem se dirige o discurso, ou o auditório, é determinada, sendo os legisladores e juízes competentes a quem se deve convencer. ${ }^{27}$

No que diz respeito ao auditório, pode-se dizer que o das decisões produzidas por um tribunal constitucional como o STF é universal, no sentido de que as decisões devem ser convincentes a um público indistinto e não particular. Diferentemente, por exemplo, da peça do advogado que compõe o mesmo processo, que possui um auditório particular bem definido, qual seja o composto pelos juízes desse órgão.

Outro conceito relevante para as decisões judiciais, cujo estudo se deu na retórica desde suas origens, é o do silogismo. O silogismo seria uma forma de ordenar o pensamento onde constam ao menos uma premissa maior (PM) e uma premissa menor

\footnotetext{
${ }^{25}$ A citação de jurisprudência certamente ultrapassa a mera noção do argumento de autoridade como técnica retórica, mas guarda algo desse conceito.

${ }^{26}$ É clássica a distinção entre convencimento e persuasão realizada no Tratado da Argumentação jurídica: "Propomo-nos chamar persuasiva a uma argumentação que pretende valer só para um auditório particular e chamar convincente àquela que deveria obter a adesão de todo ser racional". E esclarece: "persuadir é mais do que convencer, pois a conviçção não passa da primeira fase que leva à ação". PERELMAN, Chaim \& OLBRECHTS-TYTECA, Lucie. Tratado da Argumentação: a nova retórica. Maria Ermantina de Almeida Prado Galvão (Trad.). São Paulo: Martins Fontes, 2005, p. 30 e 31.

${ }^{27}$ PERELMAN, Chaïm. Ética e Direito. $2^{\text {a }}$ ed. Trad. Maria Ermantina de A. P. Galvão. São Paulo, 2005, p. 555 .
} 
(Pm) que levam a uma conclusão (C). A verdade da conclusão dependeria da verdade das premissas. Um exemplo clássico de silogismo é: PM: Todo homem é mortal; Pm: Sócrates é homem; C: Sócrates é mortal. O raciocínio silogístico é limitado e não satisfaz a complexidade do discurso retórico, que busca convencer e persuadir o auditório.

Por isso a retórica trabalha o conceito formulado desde Aristóteles de entimema, que Eduardo Bittar em sua obra afirma ser o "silogismo retórico, a mais firme das provas por persuasão". ${ }^{28}$

O entimema seria um silogismo incompleto porque traria parte de suas premissas ocultas. Em um argumento retórico não seria necessário, ou muitas vezes possível, destrinçar todo o silogismo, uma vez que simplificar a demonstração do raciocínio pode deixar o discurso mais persuasivo. João Maurício Adeodato afirma que do ponto de vista lógico o entimema parece deficiente, porém "essa aparente deficiência, pelo menos do ponto de vista da completude lógica, é justamente responsável pela força retórica do entimema". É que "a comunicação se dá como se houvesse acordo a respeito daquela premissa ou conclusão sobra a qual se silencia". ${ }^{29}$

Um exemplo de entimema seria: venceremos porque somos mais fortes. Analisando as premissas e conclusões do entimema, tem-se: PM: Os mais fortes sempre vencem; Pm: Nós somos os mais fortes; C: Nós venceremos porque somos os mais fortes. As premissas são ocultas, muitas vezes, e esse é o caso do exemplo, já que as premissas possuem algumas falhas em relação à sua possibilidade de refutação. Será que os mais fortes sempre vencem ou vencem na maioria das vezes? Nós somos realmente os mais fortes? Esse tipo de questionamento com as premissas expostas levaria a uma menor chance de convencimento do argumento.

A análise da retórica mostra-se eficiente no uso de argumentos consequencialistas num cenário onde as decisões jurídicas são justificadas por uma série de premissas muitas vezes incompletas e que servem de apoio ao raciocínio silogístico/dedutivo que é colocado com destaque.

Numa decisão, o protagonismo é certamente do momento em que o dispositivo que incide sobre o caso é indicado, realizando o raciocínio baseado na dedução da norma geral sobre o fato julgado. No entanto, ao analisar todo o raciocínio desenvolvido nas decisões, é possível observar que outros argumentos que não o silogístico/dedutivo têm

${ }^{28}$ BITTAR, Eduardo C. B. Curso de Filosofia Aristotélica: leitura e interpretação do pensamento aristotélico. Barueri: Manoel, 2003, p. 1.294.

${ }^{29}$ ADEODATO, João Maurício. Uma Teoria Retórica da Norma Jurídica e do Direito Subjetivo. São Paulo: Noeses, 2011, p. 302. 
peso fundamental na decisão. Muitas vezes os juízes e tribunais demonstram em sua argumentação razões diferentes que justificam os dispositivos; em outras, as premissas podem ficar ocultas sob a forma de entimema.

Ao expor suas premissas, por exemplo, de que as decisões não podem ter impactos negativos profundos nas contas públicas, o tribunal seria demasiadamente criticado, e pode preferir, diante do caso concreto, estipular conclusões sem premissas muito claras, ou utilizando-se de premissas meramente formais, que não exprimem verdadeiramente os fundamentos jurídicos da decisão.

Uma questão que se coloca nesse ponto seria a da adequação da análise retórica para textos judiciais. Posta a noção de que a retórica se ocupa de textos ou discursos que visam à persuasão ou ao convencimento, as decisões judiciais visam convencer algum auditório ou apenas procuram estabelecer deduções válidas de normas sobre fatos jurídicos?

Chaïm Perelman nos esclarece tal questão:

Mas, ao mesmo tempo, cresce o papel da argumentação e da retórica na aplicação e na evolução do direito. E essa observação diz menos respeito ao advogado do que ao juiz, forçado, cada vez mais, a uma motivação das sentenças que já não se contenta em mostrar a correção formal, mas se esforça em torná-las convincentes. ${ }^{30}$

Os juízes, considerados de maneira ampla, são obrigados cada vez mais a expor decisões que, além de fundamentadas, ${ }^{31}$ convençam o auditório jurídico de que aqueles argumentos são suficientes e os melhores para se chegar a tais conclusões. Ainda mais na realidade brasileira, em que as decisões são sempre extensas e longamente fundamentadas, especialmente no tribunal que será objeto de estudo deste trabalho, o Supremo Tribunal Federal.

E os tribunais também desejam que suas decisões sejam convincentes, pois a sua legitimidade enquanto tribunal depende disso. O aspecto retórico da decisão é, portanto, importante, como ressaltou Perelman.

\footnotetext{
${ }^{30}$ PERELMAN, Chaïm. Ética e Direito. $2^{\text {a }}$ ed. Trad. Maria Ermantina de A. P. Galvão. São Paulo: Martins Fontes, 2005, p. 557.

${ }^{31}$ Por que são também constitucionalmente obrigados a fazê-lo no art. 93, IX: "todos os julgamentos dos órgãos do Poder Judiciário serão públicos, e fundamentadas todas as decisões, sob pena de nulidade, podendo a lei limitar a presença, em determinados atos, às próprias partes e a seus advogados, ou somente a estes, em casos nos quais a preservação do direito à intimidade do interessado no sigilo não prejudique o interesse público à informação”. BRASIL. Constituição da República Federativa do Brasil.
} 
Ademais, o raciocínio dedutivo, que estabelece silogismos baseados na subsunção de normas jurídicas aos fatos, nem sempre é o decisivo, apesar do destaque que possui nas decisões judiciais brasileiras. É que argumentos aparentemente periféricos, como os consequencialistas, podem ter um peso mais importante no sentido do convencimento exposto no julgamento, mas, por questões de legitimidade, são postos como acessórios à subsunção da lei ao fato.

Nesse sentido, João Maurício Adeodato afirma que há

motivos estratégicos para a defesa da verdade, pelo menos entre os juristas práticos, que escondem o caráter retórico de sua profissão para fortalecer os próprios argumentos. Ao defender uma "verdade da lei e dos fatos", sem reconhecer que se trata de "meras" opiniões, o jurista apresenta-se como "teórico" ou cientista, e não como doutrinador ou dogmático. ${ }^{32}$

Essa citação do jurista-filósofo pernambucano reflete um dos objetivos da tese: demonstrar que o uso de argumentos consequencialistas pode ser estruturado com base em princípios e regras do sistema jurídico. Decisões judiciais, quando prolatadas, utilizam institutos jurídicos, normalmente princípios, como, por exemplo, segurança jurídica, igualdade, justiça e equidade, para fundamentar o que num certo sentido pode ser classificado como argumento consequencialista, ocultando as premissas que levaram a tais conclusões sobre determinados argumentos decisórios.

A retórica, portanto, permite que se estude uma decisão analisando raciocínios formados por entimemas, não passíveis de subsunção, como exigido pelas teorias analíticas e positivistas estritas de uma maneira geral, mas que muitas vezes convencem e demonstram ter sido importantes para se chegar ao resultado final do julgamento.

O estudo da retórica está relacionado, no que diz respeito ao setor jurídico, ao limite do uso de argumentos pelo próprio direito. Isto é, quais argumentos são juridicamente aceitáveis e quais argumentos seriam extrajurídicos, proibidos ou não aconselháveis a uma decisão bem fundamentada. Trata-se do debate acerca do ativismo judicial e das limitações impostas ao Judiciário no trato de questões jurídicas.

\footnotetext{
32 ADEODATO, João Maurício. A Retórica Constitucional: sobre tolerância, direitos humanos e outros fundamentos éticos do direito positivo. São Paulo, Saraiva, 2010, p. 51 e 52.
} 


\subsection{Separação dos Poderes: do self restraint ao ativismo judicial}

Um debate constante em qualquer contexto democrático é o da fixação de limites para a atuação dos Poderes. Sua separação não pressupõe uma noção estanque do que cada órgão deve exercer da parcela do Poder, mas uma constante aferição dos freios e contrapesos que equilibram esse exercício.

A expressão ativismo judicial denota um excesso do Judiciário no uso da competência constitucional ao adentrar em funções específicas dos demais Poderes, porém:

Se o ativismo judicial, em uma noção preliminar, reporta-se a uma disfunção no exercício da função jurisdicional, em detrimento, notadamente, da função legislativa, a mencionada diferença de grau permite compreender por que nos ordenamentos filiados ao common law é muito mais difícil do que nos sistema de família romano-germânica a caracterização do que seria uma atuação ativista da magistratura, a ser repelida em termos dogmáticos, em contraposição a uma atuação mais ousada, porém ainda dentro dos limites do juridicamente permitido. ${ }^{33}$

Segundo Elival Ramos, se a expressão denota uma disfunção do exercício da função jurisdicional em detrimento especialmente da função legislativa, quem se utiliza dessa expressão tem como pressuposto a ideia de que o Judiciário não deveria atuar naquele momento, ou que estaria ultrapassando as competências constitucionais outorgadas em detrimento da capacidade de o Poder Legislativo regular as questões.

Pode-se dizer que o debate acerca do ativismo judicial ${ }^{34}$ está inserido na discussão sobre argumentação jurídica. Isto é, uma das possibilidades de análise do tema do ativismo judicial dá-se por meio da observação dos argumentos utilizados nas decisões judiciais para verificação dos limites jurídicos adequados às Cortes. Pretende-se resolver, pois, as seguintes questões: quais são os argumentos adequados para o Judiciário na resolução de questões jurídicas e quais os inadequados? Onde o terceiro Poder estaria adentrando em fundamentos que seriam mais adequados aos demais Poderes, como o planejamento de políticas públicas e a eficiência de certas medidas econômicas, por

\footnotetext{
${ }^{33}$ RAMOS, Elival da Silva. Ativismo Judicial: parâmetros dogmáticos. São Paulo: Saraiva, 2010, p. 107.

34 Interessante ressaltar que a preocupação com o "ativismo judicial" ou ao menos com os limites da atividade jurisdicional remontam a Aristóteles, que afirmou no citado livro sobre a Retórica: “Argumentaremos também que o juiz, como aquele que arbitra, é quem delibera e distribui a justiça, não lhe competindo, portanto, indagar pelo significado das cláusulas de um documento, mas sim descobrir onde reside a justiça e propiciar uma solução mais justa". ARISTÓTELES. Retórica. São Paulo: Edipro, 2011, p. 115.
} 
exemplo? Nessa perspectiva, o Judiciário não estaria autorizado a levantar argumentos que extrapolariam seu exercício constitucional do Poder. ${ }^{35}$

André Ramos Tavares relata que desde que o juiz Marshall da Suprema Corte estadunidense avocou para esta a responsabilidade pela supremacia da Constituição, o Judiciário passou a enfrentar as acusações de usurpar um espaço que não teria sido atribuído pela Carta daquele país. ${ }^{36}$ A discussão sobre ativismo judicial, assim, além de essencial à democracia, é também inerente ao controle de constitucionalidade.

No contexto brasileiro, é salutar observar o incremento desse debate, colocando o Judiciário sob a atenção da opinião de juristas e pública acerca de seus limites constitucionais.

Nos últimos anos, talvez por falta de critérios claros para se decidir questões de natureza de Direito Financeiro, muitas decisões no Brasil foram criticadas por serem fenômenos do ativismo judicial, até mesmo em detrimento de normas aprovadas pelos parlamentos, como as leis orçamentárias. O debate é caloroso, por exemplo, em questões como a provisão pelo juiz de medicamentos, de tratamentos de saúde ou quaisquer outras questões que gerem custos ao Poder Público.

Há, na verdade, vários debates que giram em torno do tema, especialmente no Direito Financeiro, como o da separação dos Poderes, a legitimidade de o Poder Judiciário decidir sobre políticas públicas, além do tema central desta tese: o controle de constitucionalidade de normas orçamentárias.

Toda a concepção das leis orçamentárias está baseada na separação de Poderes, entre quem planeja/executa e quem aprova/controla. Essa divisão, apesar de subsistir, não pode ser interpretada como absoluta em razão de que tal princípio foi projetado num momento histórico diferente do atual, pois, como afirma Clèmerson Clève, "o poder não pode ser estudado à margem da história. Cabe à história, afinal, demonstrar o sentido que os conceitos assumem em cada período". 37

Já para Posner, o dúbio aspecto da teoria da separação dos Poderes é a ideia de que os juízes não devem fazer o direito ${ }^{38}$, mas meramente aplicá-lo. ${ }^{39} \mathrm{O}$ juiz não precisa

\footnotetext{
${ }^{35}$ Interessante, no entanto, a ressalva de Perelman, de que se tende a qualificar de político todo julgamento que se afaste demais da opinião média, pois esse juízo também seria de valor, e, portanto, deve ser visto com ressalva. PERELMAN, Chaïm. Ética e Direito. $2^{a}$ ed. Trad. Maria Ermantina de A. P. Galvão. São Paulo, 2005 , p. 566.

36 TAVARES, André Ramos. Paradigmas do Judicialismo Constitucional. São Paulo: Saraiva, 2012, p. 60.

${ }^{37}$ CLÈVE, Clèmerson Merlin. Atividade Legislativa do Poder Executivo no Estado Contemporâneo e na Constituição de 1988. São Paulo: Editora Revista dos Tribunais, 1993, p. 19.

${ }^{38} \mathrm{O}$ autor utiliza a expressão "law", mas no sentido de "being the legislature's prerogative", que poderia ser traduzida também como lei.
} 
ser um ativista judicial; segundo ele, basta constituir-se como canal de decisões sobre políticas públicas, e não como formulador delas. ${ }^{40}$

Os autores brasileiros convergem na compreensão de que a norma que estipula a separação dos Poderes, outrora suprema e basilar da doutrina liberal, perdeu sua rigidez. $^{41}$

Paulo Bonavides entende, por exemplo, que:

Numa idade em que o povo organizado se fez o único e verdadeiro poder e o Estado contraiu na ordem social responsabilidades que o Estado liberal jamais conheceu, não há lugar para a prática de um princípio rigoroso de separação. ${ }^{42}$

Clèmerson Clève resolve a questão afirmando que a missão dos juristas é a de adaptar a ideia de Montesquieu à realidade constitucional atual, cumprindo ainda aparelhar o Poder Executivo para que este possa responder às crescentes demandas sociais, por outro lado, aprimorando os mecanismos de controle pelo Legislativo. ${ }^{43}$

A separação de atividades entre os Poderes, no entanto, não parece ser tão simples em alguns casos. Dessa forma, nem sempre as competências do Judiciário, embora existam, são claras o suficiente para estabelecer seus limites.

Apesar de muitas doutrinas clássicas no direito financeiro não reportarem à lei orçamentária a natureza de lei em todas as suas características, a tendência é o caminho inverso ao do self-restraint, ${ }^{44}$ que significa a autolimitação do Poder Judiciário no controle das normas orçamentárias de uma maneira geral. No decorrer desta tese será visto que a tendência observada, mas ainda não consolidada, no controle de constitucionalidade de normas orçamentárias realizado pelo Supremo Tribunal Federal é o aumento do espectro de possibilidades de controle nessa área, antes proibida ao Judiciário, que se autorrestringia.

Partindo-se do pressuposto de que o tema do ativismo judicial pode ser estudado do ponto de vista da argumentação jurídica, serão classificados os argumentos

${ }^{39}$ POSNER, Richard. Law, Pragmatism, and Democracy. Cambridge/London: Harvard University Press, 2003, p. 61.

${ }^{40}$ POSNER, Richard. Problemas de Filosofia do Direito. Trad. Jefferson Luiz de Camargo. São Paulo: Martins Fontes, 2010, p. 177.

${ }^{41}$ SILVA, José Afonso da. Curso de Direito Constitucional Positivo. 24 a ed. São Paulo: Malheiros, 2005, p. 109.

42 BONAVIDES, Paulo. Ciência Política. $10^{a}$ ed. $11^{\text {a }}$ tiragem. São Paulo: Malheiros, 2002, p. 146.

${ }^{43}$ CLÈVE, Clèmerson Merlin. Atividade Legislativa do Poder Executivo no Estado Contemporâneo e na Constituição de 1988. São Paulo: Editora Revista dos Tribunais, 1993, p. 42.

${ }^{44}$ Expressão em inglês que designa a autorrestrição dos tribunais quanto a matérias que não seriam de competência do Judiciário. 
utilizados pelo Supremo Tribunal Federal nas ações do controle de constitucionalidade de normas orçamentárias em argumentos deontológicos, consequencialistas jurídicos e consequencialistas econômicos ou extrajurídicos.

Dessa forma, além de uma análise descritiva, o trabalho construirá uma proposição normativa para estabelecer que tipo de argumentação seria adequada juridicamente pelos padrões estabelecidos nos capítulos seguintes.

A discussão do ativismo judicial neste trabalho requer, pois, uma análise da argumentação que é utilizada pelo Supremo Tribunal Federal, focada na questão dos argumentos consequencialistas e sua centralidade e importância para a disposição da decisão no controle de constitucionalidade de normas orçamentárias.

\subsection{Obiter dictum e ratio decidendi: que argumentos formam o precedente?}

A discussão sobre precedentes no Brasil é relativamente recente. É possível especular, embora sem certeza científica, ainda, que o Brasil caminha para um sistema mais parecido com o anglo-saxão, e que também o sistema do anglo-saxão caminha em direção ao romano-germânico.

É certo que há várias obras recentes sobre o tema no Brasil e que serão abordadas neste item juntamente com outras do sistema anglo-saxão para mostrar a relevância do tema para este trabalho.

Em livro referência sobre o assunto, Neil MacCormick e Robert Summers afirmam que faz parte da racionalidade humana aplicar lições do passado para resolver problemas atuais e futuros, e definem precedentes como decisões pretéritas que servem de modelo para futuras decisões. ${ }^{45}$

Há uma ideia recorrente e antiga no direito de que as decisões judiciais devem seguir outras que disciplinaram casos semelhantes no passado. Robert Summers afirma que, nos Estados Unidos, esse princípio seria parte da experiência legal americana desde

45 "Precedents are prior decisions that function as models for later decisions". MACCORMICK, Neil \&SUMMERS, Robert S. Interpreting Precedents: a comparative study. Aldershot: Darthmouth Publishing Company Limited, 1997, p. 1. 
antes da revolução civil no século XVIII, o que poderia ser chamado de stare decisis. ${ }^{46} \mathrm{~A}$ expressão vem da frase em latim "stare decisis e non quieta movere", que significa: manter a decisão e não mover o que está quieto.

A primeira desvantagem da ideia do stare decisis e de manter o que foi decidido é o aspecto conservador que dá ao direito. Como se o direito não pudesse se adaptar a novas realidades, devendo sempre manter o que foi decidido. Por outro lado, manter as decisões cumpre dois objetivos fundamentais encontrados nos ordenamentos jurídicos modernos, que são a segurança jurídica e a igualdade. Manter as mesmas decisões do passado possibilita a previsibilidade das decisões, o que gera segurança jurídica. Ao mesmo tempo, decisões díspares no mesmo sistema podem criar situações de desigualdade, regulando matérias e situações semelhantes de forma diversa.

Em sentido inverso ao conceito de MacCormick e Summers como decisões pretéritas que servem de modelo para futuras decisões, Mariana Moreto chama de precedente "toda decisão judicial proferida por autoridade judiciária", mesmo que a decisão seja dissonante da jurisprudência dominante e assuma posicionamento isolado. ${ }^{47} \mathrm{~A}$ ideia apresentada pela autora é a de que alguns requisitos dados aos precedentes seriam, na verdade, próprios da jurisprudência, como a necessidade de constância e de uniformização.

Aqui não se adota a posição da autora citada justamente porque se entende terem os precedentes um papel fundamental na orientação das futuras decisões. Evidentemente que nesse sentido qualquer decisão pode ser utilizada como fundamento para decisões futuras, embora a grande maioria não o seja. Daí viria a difícil tarefa de compreender o sistema onde as decisões se situam, apontando quais são seguidas hoje e quais serão provavelmente padrões a ser seguidos no futuro pela jurisprudência.

Segundo MacCormick e Summers, os precedentes representam a ideia de direito em dois sentidos: num, um membro do sistema observa a decisão proferida por outro no mesmo sistema legal para resolver um problema semelhante; e noutro, que não observa a decisão como uma mera decisão anterior, mas como um modelo de solução do problema, seguindo uma orientação de que parece correto ou mesmo obrigatório seguir os passos trilhados anteriormente. ${ }^{48}$

\footnotetext{
${ }^{46}$ SUMMERS, Robert S. Precedent in the United States (New York State), in MACCORMICK, Neil \& SUMMERS, Robert S. Interpreting Precedents: a comparative study. Aldershot: Darthmouth Publishing Company Limited, 1997, p. 355.

${ }^{47}$ MORETO, Mariana C. L. O Precedente Judicial no Sistema Processual Brasileiro. Tese de Doutorado. Faculdade de Direito da Universidade de São Paulo. São Paulo, 2012, p. 19.

48 MACCORMICK, Neil \&SUMMERS, Robert S. Interpreting Precedents: a comparative study. Aldershot: Darthmouth Publishing Company Limited, 1997, p. 3.
} 
Ressaltam ainda MacCormick e Summers que existe um aspecto voltado para o futuro dos precedentes que vai além do modelo para decisões. É que o estabelecimento de um precedente dá a entender que as decisões no futuro serão tomadas daquela mesma forma, o que pode influenciar a tomada de decisão das pessoas. ${ }^{49}$ Tal noção irá complementar a ideia de universalidade das decisões, tema que será tratado no capítulo 3 desta primeira parte da tese.

Marinoni, alinhado à ideia de que nem toda decisão é precedente, estabelece alguns requisitos para que ela seja considerada um precedente. Para o autor, não basta que a decisão seja a primeira a interpretar a norma, mas deve também enfrentar todos os principais argumentos relacionados à questão de direito, sendo a primeira decisão que elabora a tese jurídica, ou a que definitivamente a delineia, deixando a tese clara e objetiva. $^{50}$

O precedente, entretanto, não se confunde com a decisão judicial. Luiz Guilherme Marinoni esclarece tal questão:

Seria possível pensar que toda decisão judicial é um precedente. Contudo, ambos não confundem, só havendo sentido falar de precedente quando se tem decisão dotada de determinadas características, basicamente a potencialidade de se firmar como paradigma para a orientação dos jurisdicionados e dos magistrados. ${ }^{51}$

Nem toda decisão judicial produz precedente, portanto. E mais, nem toda decisão judicial que produz precedente produz em sua inteireza. Isto é, apenas parte da decisão pode configurar o precedente. A análise do que caracteriza um precedente é, por sua vez, uma análise argumentativa.

Nesse ponto, o tema dos precedentes toca a teoria da argumentação e as teorias retóricas sobre o direito. Só é possível analisar que partes da decisão formam o precedente se observada a argumentação desenvolvida, e é possível dentre outras formas usar a lente da retórica para entender que pontos da decisão são mais convincentes e, portanto, potencialmente orientarão os jurisdicionados e magistrados a decidir da mesma forma no futuro.

Uma das discussões sobre precedentes é a necessidade de serem estes vinculantes ou não. Robert Alexy, ao tratar dos precedentes na Alemanha, afirma que a sua

49 MACCORMICK, Neil \& SUMMERS, Robert S. Interpreting Precedents: a comparative study. Aldershot: Darthmouth Publishing Company Limited, 1997, p. 2.

${ }^{50}$ MARINONI, Luiz Guilherme. Precedentes Obrigatórios. $2^{a}$ ed. São Paulo: Saraiva, 2011, p. 216.

${ }^{51}$ Idem, p. 215. 
noção pressupõe algum tipo de vinculação, sendo suficiente para caracterizar como precedente tão só o fato de que a decisão seja relevante para qualquer outra futura. ${ }^{52}$

A vinculação do precedente, que significa torná-lo obrigatório, seria o maior estágio de força que uma decisão produziria num ordenamento. A força do precedente, no entanto, pode variar em função dos seguintes elementos: i) contexto institucional; ii) tradição jurídica; iii) sistema constitucional; iv) teorias jurídico-dogmáticas dominantes. ${ }^{53}$

No contexto institucional brasileiro não se pode falar em precedentes vinculantes, embora as mudanças legislativas recentes, como a instituição dos recursos repetitivos e da repercussão geral, caminhem para fortalecê-los.

O precedente também não coincide com o fenômeno da coisa julgada. $\mathrm{O}$ artigo 469 do Código de Processo Civil brasileiro afirma que não fazem coisa julgada "os motivos, ainda que importantes para determinar o alcance da parte dispositiva da sentença". 54

Por tal motivo, o efeito do precedente, apesar de mais incerto, é mais amplo que o da coisa julgada. Isso porque se a coisa julgada atinge apenas o dispositivo, como afirma o Código de Processo Civil brasileiro, o precedente não pode ser entendido sem a fundamentação jurídica que o integra.

Os precedentes são formados por um raciocínio eminentemente indutivo, no qual as conclusões gerais são tiradas a partir de fatos concretos. Trata-se do caminho inverso ao que se pretende tradicional no direito brasileiro, que é o dedutivo, partindo da norma geral e abstrata da lei para entender o que deve ser aplicado ao caso concreto. Temse aqui, portanto, uma "norma" que nasce do caso concreto e que servirá para orientação dos tribunais.

$\mathrm{Na}$ verdade, a análise que o precedente requer é quase que exclusivamente fática. Assumindo que a solução jurídica está posta, a análise desenvolvida basicamente é: esse caso é tão parecido com o outro que merece o mesmo tratamento jurídico? Em caso positivo, o direito "definido" pelo precedente é aplicado ao segundo caso. Do contrário, aplica-se a técnica distinguishing, ${ }^{55}$ que significa o exercício de distinguir uns casos dos

\footnotetext{
${ }^{52}$ ALEXY, Robert. Precedent in the Federal Republic of Germany, in MACCORMICK, Neil \& SUMMERS, Robert S. Interpreting Precedents: a comparative study. Aldershot: Darthmouth Publishing Company Limited, 1997, p. 23.

${ }^{53}$ MACCORMICK, Neil. Precedent as a source of Law, in ATTWOOL, Elspeth, e COMMANDUCCI, Paolo (org.). Sources of Law and Legislation: proceedings of the $17^{\text {th }}$ World Congress of the International Association for Philosophy of Law and Social Philosophy (IVR). Bologna: IVR, 1995, p. 172.

${ }_{54}^{54}$ BRASIL. Lei n ${ }^{\circ} 5.869$ de 11 de janeiro de 1973.

${ }^{55}$ Sobre o tema, no Brasil, ver: MARINONI, Luiz Guilherme. Precedentes Obrigatórios. $2^{\mathrm{a}}$ ed. São Paulo: Saraiva, 2011.
} 
outros, faticamente, ou por meio do reconhecimento de uma exceção direta à regra judicial invocada, ou pelo estabelecimento de uma exceção indireta, quando os fatos do caso são reclassificados como algo diferente para evitar a aplicação do precedente. ${ }^{56}$

Ressalta, na mesma linha, Maurício Ramires que fato e direito são indissociáveis: "Em outras palavras, o estabelecimento do direito em casos obriga o intérprete a pensar o direito como faticidade, pois não pode simplesmente descolar o texto da situação concreta que lhe deu origem". ${ }^{57,58}$

Tucci analisa com as mesmas premissas a composição do precedente e encontra "duas partes distintas: a) as circunstâncias de fato que embasam a controvérsia; e b) a tese ou o princípio jurídico assentado na motivação (ratio decidendi) do provimento decisório". 59

A tópica ${ }^{60}$ enquanto método argumentativo derivado da retórica ajuda a compreender o papel dos fatos na composição do precedente, sendo uma técnica do pensamento voltado para o problema. ${ }^{61}$ Há uma oposição na tópica entre o clássico pensamento sistemático e o pensamento problemático, em que o problema, composto por fatos, é o centro do raciocínio indutivo que leva ao entendimento sobre o direito no caso.

Para entender o precedente, portanto, não é possível excluir a análise do caso concreto e do problema que levou a determinada decisão. Em outro sentido, o mesmo Marinoni reconhece que "É intuitivo que, para aplicar a ratio decidendi a um caso, é necessário comparar o caso de que provém a ratio decidendi com o caso sob julgamento, analisando-se as suas circunstâncias fáticas". ${ }^{62}$

Mas o que vem a ser ratio decidendi, ou holding, no direito do common law, e o obiter dictum, e como identificá-los nas decisões analisadas?

\footnotetext{
${ }^{56}$ BUSTAMANTE, Thomas da Rosa. Teoria do Precedente Judicial: a justificação e a aplicação de regras jurisprudenciais. São Paulo: Noeses, 2012, p. 470 e 471.

${ }^{57}$ RAMIRES, Maurício. Crítica à Aplicação de Precedentes no Direito Brasileiro. Porto Alegre: Livraria do Advogado, 2010, p. 71.

${ }^{58}$ No mesmo sentido, STRECK, Lênio. Da Interpretação dos Textos à Concretização de Direitos: a incindibilidade entre interpretar e aplicar a partir da diferença ontológica (ontologische differentz) entre texto e norma, in Constituição, Sistemas Sociais e Hermenêutica - Anuário do Programa de Pós-Graduação em Direito da Unisinos. Porto Alegre, 2006, p. 150.

${ }^{59}$ TUCCI, José Rogério Cruz e. Precedente judicial como fonte do direito. São Paulo: RT, 2004, p. 12.

${ }^{60}$ Tércio Sampaio Ferraz Jr. explica que tópica é o nome de um dos livros do Organon aristotélico, e que seus conceitos e proposições "constituiam não axiomas nem postulados de demonstração, mas topoi de argumentação, isto é, lugares (comuns), fórmulas, variáveis no tempo e no espaço, de reconhecida força persuasiva no confronto de opiniões". FERRAZ JR., Tércio. Introdução ao Estudo do Direito: técnica, decisão e dominação. $3^{\text {a }}$ ed. São Paulo: Atlas, 2001, p. 322.

${ }^{61}$ VIEHWEG, Theodor. Tópica e Jurisprudência: uma contribuição à investigação dos fundamentos jurídico-científicos. $5^{\mathrm{a}}$ ed. Trad. Kelly S. Alflen da Silva. Porto Alegre: Sergio Antonio Fabris Editor, 2008, p. 33.

${ }^{62}$ MARINONI, Luiz Guilherme. Precedentes Obrigatórios. $2^{a}$ ed. São Paulo: Saraiva, 2011, p. 327.
} 
Ratio decidendi ou holding seriam "os fundamentos jurídicos que sustentam a decisão; a opção hermenêutica adotada na sentença, sem a qual a decisão não teria sido proferida como foi; trata-se da tese jurídica acolhida pelo órgão julgador no caso concreto", 63 ou segundo Conrado Mendes, os "fundamentos definitivos para decidir a prescrição que pode ser aplicada a casos futuros". ${ }^{64}$ Neil MacCormick afirma que ratio decidendi seria uma regra (ruling) expressa ou implícita dada por um juiz, suficiente para estabelecer uma proposição jurídica (point of $l a w^{65}$ ) desenvolvida a partir da argumentação das partes e que componha a justificação necessária para determinar tal regra. ${ }^{66}$

Embora nem toda decisão constitua um precedente, no sentido de orientar as decisões que são tomadas no futuro, todas as decisões possuem um ratio decidendi, que constitui o núcleo essencial argumentativo da decisão, como dito acima. Identificar esse núcleo, como tudo no direito, nem sempre é fácil ou incontroverso.

A parte da decisão chamada de obiter dictum é definida por exclusão, de forma que aquilo que não preenche as características essenciais da decisão, segundo os critérios adotados em cada opção metodológica, seria alocado nessa categoria. Conrado Mendes pondera: "o dictum de hoje pode se transformar no ratio decidendi de amanhã? Talvez. Depende da inteligência e da criatividade do intérprete". ${ }^{67}$

Cabe ao intérprete, portanto, e só a ele, definir o que é ratio decidendi e obiter dictum em cada decisão. Por isso, a argumentação considerada obiter dictum não pode ser desprezada, como ressaltado nesta passagem:

O obiter dictum, embora não sirva como precedente, não é desprezível. O obiter dictum pode sinalizar uma futura orientação do tribunal, por exemplo. Além disso, o voto vencido em um julgamento colegiado é obiter dictum e tem a sua relevância para a elaboração do recurso dos

\footnotetext{
${ }^{63}$ DIDIER JR., Fredie, BRAGA, Paula S. \& OLIVEIRA, Rafael. Curso de direito processual civil. Vol. 2, Teoria da prova, direito probatório, teoria do precedente, decisão judicial, coisa julgada e antecipação dos efeitos da tutela. Salvador: JusPODIVM, 2012, p. 385.

${ }^{64}$ MENDES, Conrado H. Lendo uma decisão: obiter dictum e ratio decidendi, racionalidade e retórica na decisão. Sociedade Brasileira de Direito Público. Disponível em: <http://www.sbdp.org.br/arquivos/material/19_Estudo\%20dirigido\%20$\% 20$ Ratio $\% 20$ decidendi $\% 20 \mathrm{e} \% 20$ obter\%20dictum\%20-\%20Conrado\%20Hubner\%20Mendes.pdf $>$. Acesso em 24.10.2013.

65 "A discrete legal proposition at issue in a case". GARNER, Bryan A. (Editor). Black's Law Dictionary. $9^{a}$ ed. St. Paul: Thomson Reuters, 2005.

${ }^{66}$ MACCORMICK, Neil. Legal Reasoning and Legal Theory. Oxford: Clarendon Press, 1994, p. 215.

${ }^{67}$ MENDES, Conrado H. Lendo uma decisão: obiter dictum e ratio decidendi, racionalidade e retórica na decisão. Sociedade Brasileira de Direito Público. Disponível em: <http://www.sbdp.org.br/arquivos/material/19_Estudo\%20dirigido\%20$\% 20$ Ratio $\% 20$ decidendi $\% 20 \mathrm{e} \% 20$ obter\%20dictum\%20-\%20Conrado\%20Hubner\%20Mendes.pdf $>$. Acesso em 24.10.2013.
} 
embargos infringentes, bem como tem eficácia persuasiva para uma tentativa futura de superação do precedente. ${ }^{68}$

A distinção entre os dois conceitos é relevante na prática para entender o que da decisão importa para servir de standard para comportamentos que procuram se adequar ao direito. A isso MacCormick chama de dimensão da universalidade das decisões, como será visto no terceiro capítulo desta primeira parte.

Uma proposta objetiva, que busca encontrar quais decisões servem de precedentes, é a produzida por Adriana Vojvodic em sua tese de doutorado apresentada na Universidade de São Paulo. A tese defende a busca de precedentes por meio do estudo das citações presentes nas decisões.

Poder-se-iam encontrar os precedentes observando as "decisões mais importantes que acabam sendo citadas por diversas vezes em casos subsequentes, acompanhando o desenvolvimento de uma linha jurisprudencial". ${ }^{69}$ Esse método é eficiente para encontrar as decisões que servem de formação para o precedente, mas não os argumentos que compõem a ratio decidendi, e que, portanto, constituem o precedente nas decisões já identificadas.

No caso da tese ora apresentada, certamente o critério da escolha das decisões a serem analisadas levará em conta, como se verá, de forma simplificada, a citação das decisões, além da indicação da doutrina já produzida sobre o tema que aponta as decisões mais importantes, somadas à pesquisa decorrente desses critérios.

Tucci propõe um critério interessante para aferir os argumentos que compõem a ratio decidendi, uma vez definida a decisão:

Para a correta inferência da ratio decidendi, propõe-se uma operação mental, mediante a qual, invertendo-se o teor do núcleo decisório, se indaga se a conclusão permaneceria a mesma, se o juiz tivesse acolhido a regra invertida. Se a decisão ficar mantida, então a tese originária não pode ser considerada ratio decidendi; caso contrário, a resposta será positiva. $^{70}$

\footnotetext{
${ }^{68}$ DIDIER JR., Fredie, BRAGA, Paula S. \& OLIVEIRA, Rafael. Curso de direito processual civil. Vol. 2, Teoria da prova, direito probatório, teoria do precedente, decisão judicial, coisa julgada e antecipação dos efeitos da tutela. Salvador: JusPODIVM, 2012, p. 388.

${ }^{69}$ VOJVODIC, Adriana de Moraes. Precedentes e Argumentação no Supremo Tribunal Federal: entre a vinculação ao passado e a sinalização para o futuro. Tese de Doutorado. Faculdade de Direito da Universidade de São Paulo. São Paulo, 2012, p. 118.

${ }^{70}$ TUCCI, José Rogério Cruz e. Precedente judicial como fonte do direito. São Paulo: RT, 2004, p. 177.
} 
As noções desenvolvidas neste primeiro capítulo são essenciais para o trabalho que se inicia. Serão, contudo, ainda mais importantes no último capítulo do trabalho, onde decisões judiciais serão analisadas sob tais premissas, na busca dos argumentos que formam os precedentes, com foco na preponderância de argumentos chamados consequencialistas. O tema consequencialismo será visto nos dois próximos capítulos. 


\section{TEORIAS CONSEQUENCIALISTAS E O DIREITO}

2.1 Que é consequencialismo?

2.2 Consequencialismo na filosofia moral

2.3 Consequencialismo na tradição utilitarista

2.4 Consequencialismo no pragmatismo e na análise econômica do direito

2.5 Consequencialismo e direito

A tese pretende abordar a possibilidade de controle jurisdicional orçamentário sob uma perspectiva fundada em argumentos sobre consequências jurídicas. Este capítulo se destina a averiguar as diversas perspectivas existentes sobre o consequencialismo, especialmente o jurídico, mais desenvolvido em países de tradição anglo-saxã. Isso não quer dizer que os tribunais de outras tradições, como no caso dos brasileiros, não utilizem tais argumentos em suas decisões judiciais. $\mathrm{Na}$ verdade, uma das hipóteses centrais desta tese é a de que o argumento consequencialista é utilizado nas decisões que tratam do controle de constitucionalidade de leis e normas orçamentárias. O debate sobre tais argumentos precisa ser mais bem estabelecido, esclarecendo todos os lados para que os participantes possuam iguais armas para defender ou reprimir o seu uso.

Apesar de não ser o único referencial teórico para este capítulo, será dado certo protagonismo ao autor Richard Posner, pela sua importância especialmente nos temas objeto dos tópicos 2.3, 2.4 e 2.5. Estes tratam do consequencialismo nas tradições utilitaristas, pragmatistas e da análise econômica do direito, pois o autor produziu nas três escolas do pensamento e possui influência inegável no direito e, sobremodo, no estudo do consequencialismo.

Os fundamentos postos neste capítulo serão essenciais para se contrapor à ideia de consequencialismo defendida por Neil MacCormick no capítulo seguinte, e cujo desfecho orientará a produção dos capítulos finais da tese.

\subsection{Que é consequencialismo?}

No quarto episódio da primeira temporada da série americana House, o médico, personagem principal do programa, se depara com o seguinte dilema ético: seis 
bebês estão doentes, e dois deles já manifestam a forma mais avançada da patologia. Os médicos chegaram à conclusão de que apenas duas doenças podem provocar os sintomas dos bebês. Pela demora quanto ao resultado dos exames para diagnosticar exatamente a doença de todos os seis, que é a mesma, House propõe que cada um dos dois bebês no estágio mais avançado seja tratado de acordo com uma das duas prováveis doenças. Isso salvaria um dos bebês, e os demais seriam tratados de acordo com esse diagnóstico, o que poderia ter consequências fatais para o bebê tratado de acordo com a outra patologia.

O dilema moral apresentado acima representa a discussão sobre o consequencialismo, uma expressão que abarca uma série de tendências filosóficas sobre a análise dos resultados da ação humana. O tema do consequencialismo, portanto, transborda o direito, mas a ele interessa, por tratar de critérios de julgamento.

Quando decisões são tomadas, as consequências previsíveis nesse momento são consideradas. No plano moral, as pessoas consideram suas ações boas ou ruins se as consequências delas advindas foram relevantes para um lado ou para o outro. No caso, por exemplo, de um físico que produziu um novo conhecimento sobre fusão nuclear. Se a principal consequência desse conhecimento é a produção de uma bomba que destrói parte da humanidade, é possível que muitas pessoas julgassem a ação de produzi-lo como um erro, se era previsível tal fim bélico.

Por outro lado, um ato bárbaro como o assassinato de alguém pode ser considerado por alguns uma boa ação, quando a vítima é um grande assassino ou alguém que poderia cometer muitos outros crimes no futuro.

Em outra hipótese, poderíamos considerar a ação de subornar políticos para efetivar a melhor política para a educação, que não seria aprovada sem tal prática criminosa. É possível tomar a ação como boa se, apesar dos meios ilícitos, ela gera as melhores consequências para a política pretendida. Ou ainda, no caso da tortura que serve para impedir um ataque terrorista, tema de relevância especialmente nos Estados Unidos da América, esta poderia ser aceita pelas trágicas consequências a evitar.

Pode-se afirmar com certeza que, independentemente do país, sistema moral ou jurídico, as consequências das ações são consideradas, em maior ou menor medida, e a depender de diversos fatores, de acordo com quem avalia ou com a situação avaliada etc.

Um conceito amplo de consequencialismo envolve a defesa de uma análise não exclusiva dos resultados de uma ação. Isto é, uma ação poderia ser boa ou ruim, justa ou injusta, válida ou inválida, a depender também dos resultados que produz. Num conceito estrito de consequencialismo, apenas as consequências deveriam ser relevantes para julgar 
uma determinada ação. Em todos os casos, não há uma resposta uníssona sobre quais são os resultados que devem ser considerados, como e por quê.

O Dicionário de Filosofia de Nicola Abbagnano define consequencialismo como "Vertente peculiar das éticas teológicas, ou seja, das morais que avaliam e prescrevem as ações tendo em vista seus resultados, considerando moralmente bons os comportamentos que produzem consequências boas". ${ }^{71}$

O Blacks's Law Dictionary, por sua vez, fornece uma definição de consequencialismo mais próxima e interessante para o direito: "An ethical theory that judges the rightness or wrongness of actions according to their consequences. One of the Best-known types of consequentialism is utilitarism". ${ }^{72}$

Tem-se, num primeiro momento, que as diversas teorias consequencialistas problematizam as consequências das decisões e defendem que quando uma decisão é tomada, as consequências dela decorrentes são importantes na análise do seu sucesso ou correção. Cristiano Carvalho afirma que, "para os consequencialistas, a ênfase deve ser dada aos possíveis resultados ou aos fins pretendidos pelo agente, isto é, um ato não é moral ou imoral a priori, mas será um ou outro, a depender das consequências dele resultantes". 73

As teorias consequencialistas seriam antagônicas às deontológicas. Estas, ainda no campo moral, defenderiam o "cumprimento rígido de princípios e regras que refletem valores morais". ${ }^{74}$ Aquelas se centram nos resultados e têm como objeto principal as ações, sendo "o critério máximo para a avaliação de um curso de ação ou de uma instituição o valor de suas consequências globais - os benefícios menos os custos, para todos os afetados". 75

Hans Kelsen, no clássico “Teoria Pura do Direito”, expõe o ponto deontológico ao analisar as características da causalidade jurídica. Afirma que toda norma social estabelece sempre uma relação entre uma condição e uma consequência, e prescreve que a consequência deve seguir a condição. ${ }^{76}$

\footnotetext{
${ }^{71}$ ABBAGNANO, Nicola. Dicionário de Filosofia. São Paulo, Martins Fontes, 1998.

${ }^{72}$ Em tradução livre: "Uma teoria ética que julga a correção ou incorreção de uma ação de acordo com suas consequências. Um dos mais conhecidos tipos de consequencialismo é o utilitarismo". Escolheu-se manter no original para ser fiel à definição de um dicionário. GARNER, Bryan A. (Editor). Black's Law Dictionary. 9 ed. St. Paul: Thomson Reuters, 2005.

${ }^{73}$ CARVALHO, Cristiano. Teoria da Decisão Tributária. São Paulo: Saraiva, 2013, p. 84.

74 Idem, Ibdem.

${ }^{75}$ MACCORMICK, Neil. Retórica e o Estado de Direito. Trad. Conrado Hübner Mendes. Rio de Janeiro: Elsevier, 2008, p. 58.

${ }^{76}$ KELSEN, Hans. Teoría Pura Del Derecho. Buenos Aires: Editorial Universitaria de Buenos Aires, 1960, p. 34.
} 
O deontológico, expresso em Kelsen, é, portanto, a relação do dever-ser, a imputação lógica que liga o antecedente ou a hipótese normativa à consequência estipulada e que faz parte da estrutura normativa.

Há, no entanto, dois sentidos para o deôntico nessa perspectiva jurídica, que não podem ser confundidos. Difere-se, pois, o operador deôntico dos modais deônticos.

Num primeiro sentido do deôntico, segundo Paulo de Barros Carvalho, fala-se num operador deôntico interproposicional, no qual as proposições implicante e implicada são postas numa relação de dever-ser não modalizado, expressa em " $\mathrm{D}(\mathrm{p} \rightarrow \mathrm{q})$ ", que significa "(dever-ser que p implique q)", ${ }^{77} \mathrm{O}$ operador deôntico é um deve-ser neutro, não modalizado, que apenas indica a implicação de que, se acontece a hipótese, deve ser a consequência.

Num segundo sentido, ocorre uma modalização do deôntico em três classes exclusivas: permitido $(\mathrm{P})$; obrigatório $(\mathrm{O})$; e proibido $(\mathrm{V}){ }^{78}$ Exclusivas segundo a "lei deontológica do quarto excluído: os modais deônticos são três e somente três". ${ }^{79}$ Desta forma, não há como fugir das três opções. Toda norma jurídica obriga, autoriza ou proíbe alguma conduta; não há quarta opção. ${ }^{80}$

Lourival Vilanova, referência do tema no Brasil, afirma que "Não tem sentido para uma mesma conduta exigi-la e proibi-la, proibi-la e permiti-la (no sentido da permissão bilateral de fazer ou omitir, não no sentido de permissão unilateral de fazer o obrigatório e de omitir o proibido". ${ }^{81}$

Segue afirmando Vilanova que, "Assim sendo, tem-se functor deôntico com incidência sobre a relação-de-implicação entre hipótese e tese e mais outro functor deôntico no interior da estrutura proposicional da tese". ${ }^{82}$

O padrão deontológico é o clássico modo pelo qual a decisão judicial é expressa no direito. Embora ele não possa ser desprezado, evidentemente ele é, como toda linguagem, uma simplificação da realidade, que tem como objetivo traduzir uma expressão silogística do direito.

\footnotetext{
${ }^{77}$ CARVALHO. Paulo de Barros. Direito Tributário: fundamentos jurídicos da incidência. $8^{a}$ ed. São Paulo: Saraiva, 2010, p. 48.

${ }^{78}$ Idem, p. 49.

79 Idem, p. 51.

${ }^{80}$ CHRISTOPOUlOS, Basile G. C. Despesa Pública: estrutura, função e controle judicial. Maceió: Edufal, 2011.

${ }^{81}$ VILANOVA, Lourival. As Estruturas Lógicas e o Sistema do Direito Positivo. São Paulo: Noeses, 2005, p. 146.

${ }^{82}$ Idem, p. 95.
} 
Este trabalho, como fixado no primeiro capítulo, pretende abordar o fenômeno jurídico de forma mais ampla, analisando a decisão judicial como texto retórico que busca convencer o seu auditório e que analisa o padrão deontológico como um tipo de argumentação possível no discurso jurídico, embora seja, claramente, um tipo fundamental.

Visto o deontológico como um argumento no discurso jurídico, pode-se afirmar que o argumento dessa natureza considera o que deve ser feito apenas em relação à ocorrência ou não do fato descrito na hipótese de uma norma. Se realizado o fato descrito na norma, deve-ser, pois, a consequência normativa. ${ }^{83}$ Não há espaço, ao menos a priori, nessa fórmula para que as consequências da decisão sejam consideradas.

Samuel Scheffler explica nesse viés que, em contraste com as concepções de consequencialismo, o padrão deontológico afirma que em alguns casos é errado fazer o que produzirá o melhor resultado global disponível. ${ }^{84}$ Isto é, pensando deontologicamente, mesmo as decisões que produzem resultados indesejados deveriam ser tomadas, por serem corretas.

As teorias normativas deontológicas identificariam por meio de certos critérios os direitos individuais, as exigências da imparcialidade, a proibição das discriminações arbitrárias e prescreveriam "o que se deve e o que não se deve fazer de um modo que, pelo menos em parte, é independente das consequências". 85

$\mathrm{O}$ ato consequencialista padrão avalia atos (e não regras ou motivos) como corretos caso provoquem um estado de coisas que é o melhor do ponto de vista impessoal. ${ }^{86}$ Mas não seria adequado desprezar as normas na análise da melhor decisão pelas suas consequências unicamente. Além disso, tem-se a questão de quais consequências irão importar e qual a melhor forma de avaliação destas.

O questionamento acerca do uso de consequências surge nesse contexto, onde as teorias deontológicas não são suficientes para nomear todos os argumentos utilizados

\footnotetext{
${ }^{83}$ Não há de se confundir a consequência prevista na norma com argumentos fundados nas consequências da decisão. A distinção parece clara, embora em ambos os casos seja inevitável o uso da expressão "consequência".

84 "In contrast to consequentialism conceptions, standard deontological views maintain that it is sometimes wrong to do what will produce the best available outcome overall". SCHEFFLER, Samuel. From the Rejection of Consequentialism, in DARWALL, Stephen (org.). Consequentialism. Oxford: Blackwell Publishing, 2003, p. 109.

${ }^{85}$ MACCORMICK, Neil. Retórica e o Estado de Direito. Trad. Conrado Hübner Mendes. Rio de Janeiro: Elsevier, 2008, p. 58.

86 "The standard act consequentialist directly evaluates acts (not rules or motives) as right just in case they bring about the state of affairs that is evaluated as best overall from an impersonal standpoint". HURLEY, Paul. Beyond Consequentialism. Oxford: Oxford University Press, 2011, p. 10.
} 
numa decisão judicial, que explora com frequência argumentos relacionados aos efeitos e consequências das decisões.

Serão expostas em seguida as teorias consequencialistas que mais tiveram repercussão no direito, passando pela origem na filosofia moral, para se chegar ao utilitarismo, ao pragmatismo e à análise econômica do direito.

\subsection{Consequencialismo na filosofia moral}

Antes de investigar o consequencialismo jurídico é preciso estabelecer as bases de sua investigação na filosofia, bem como a origem lógica e histórica do pensamento consequencialista.

As tradições jurídicas que tratam do consequencialismo certamente foram muito influenciadas pelo consequencialismo da filosofia moral, embora, como se verá adiante, tenham criado as suas particularidades em relação a esta.

Moral seria o campo da filosofia que busca entender como qualificar as ações humanas em termos ético-valorativos. Segundo o consequencialismo, no campo de estudo da filosofia moral, a qualidade moral de uma ação, o julgamento quanto à sua correção, seria completamente determinada pelas consequências da ação, ${ }^{87}$ e não pelo julgamento quanto à tomada da decisão em si.

Tim Mulgan afirma que o projeto moral do consequencialismo seria tornar o

mundo um lugar melhor. ${ }^{88}$ E para tornar o mundo um lugar melhor, seria mais adequado avaliar as ações de acordo com os efeitos produzidos. Dessa forma, ações que produzem os efeitos desejados para o mundo levariam a esse mundo melhor. Contudo, o que cada um entende por "mundo melhor" provocaria a mesma discussão: sobre que consequências as ações devem produzir.

O consequencialismo, nessa perspectiva, defende que a coisa certa a se fazer em qualquer situação é praticar o ato que produza as melhores consequências. ${ }^{89}$ Porém, mesmo na filosofia moral, há vários tipos de consequencialismo e em cada um deles a forma de se obter "as melhores consequências" pode ser atingida de forma diferente. O que há em

\footnotetext{
${ }^{87}$ DRIVER, Julia. Consequentialism. London: Routledge, 2012, p. 5.

${ }^{88}$ MULGAN, Tim. The Demands of Consequentialism. Oxford: Oxford University Press, 2001, p. 53.

${ }^{89}$ Idem, p. 3.
} 
comum é que "um mesmo acontecimento será interpretado, e valorizado diferentemente, conforme a ideia que se forma da natureza, deliberada ou involuntária, de suas consequências". 90

A principal teoria da filosofia moral que tratou dos questionamentos consequencialistas foi certamente a tradição utilitarista, que não se resume à análise consequencialista, mas constitui um dos núcleos fundamentais de seu pensamento. É o que se observará a seguir.

\subsection{Consequencialismo na tradição utilitarista}

O utilitarismo defende, de fato, uma das formas de consequencialismo mais conhecidas, e pode ser definido preliminarmente como uma doutrina segundo a qual se deveria agir para maximizar o bem, seja qual for o conceito de bem que se tenha. ${ }^{91} \mathrm{O}$ bem para John Stuart Mill seria a maior felicidade proporcionada pelo maior prazer e pela prevenção da dor. Mas o que interessa aqui é como esses fins são atingidos. O pensador esclarece que, para o utilitarismo defendido por ele, "as ações estão certas na medida em que tendem a promover a felicidade e erradas quando tendem a produzir o oposto da felicidade". 92

O próprio nome da teoria "utilitarismo" pressupõe lançar mão do que é útil para atingir determinados fins. Na tradição utilitarista, dessa forma, as melhores consequências seriam aquelas que maximizam os melhores efeitos, como alegria ou prazer.

Os grandes representantes da tradição clássica utilitarista, Jeremy Bentham e John Stuart Mill, discordavam sobre os fins a serem atingidos, graus de prazer ou de hedonismo que poderiam ser atingidos. Enquanto Mill propunha um hedonismo graduado, em que certos prazeres, como o intelectual, seriam mais importantes que outros, Bentham defendia um hedonismo mais igualitário. ${ }^{93}$

\footnotetext{
${ }^{90}$ PERELMAN, Chaïm; OLBRECHTS-TYTECA, Lucie. Tratado da Argumentação: a nova retórica. $2^{\mathrm{a}}$ edição. Trad. de Maria Ermantina Galvão. São Paulo: Martins Fontes, 2005, p. 308.

${ }^{91}$ MACCORMICK, Neil. Pratical Reason in Law and Morality. Oxford: Oxford University Press, 2008, p. 107.

${ }^{92}$ STUART MILL, John. Utilitarismo. Trad. Rita de Cássia G. Neiva. São Paulo: Escala, 2007, p. 22.

${ }^{93}$ DRIVER, Julia. Consequentialism. London: Routledge, 2012, p. 5 e 13.
} 
A discussão travada pelos autores apenas demonstra a dificuldade que se tem em avaliar como são atingidas as melhores consequências, quando dentro da mesma tradição utilitarista há discordância sobre o peso de cada consequência.

John Stuart Mill constrói o seu utilitarismo baseado na ideia de que “(...) o prazer e a imunidade à dor são as únicas coisas desejáveis (as quais são tão numerosas no utilitarismo quanto em qualquer outro esquema); são desejáveis ou para o prazer inerente a elas mesmas ou como meio para promoção do prazer e prevenção da dor". ${ }^{94}$ Richard Posner, em complemento, considera a visão utilitarista como aquela em que um ato ou prática é certo ou bom quando tende a aumentar a felicidade, usualmente definida como a supressão da dor pelo prazer. ${ }^{95}$

Demonstra com clareza Stuart Mill que a avaliação utilitarista tem como alicerce a análise consequencialista das ações. ${ }^{96}$ Isto é, se o objetivo do utilitarismo é a maximização da felicidade, as ações são boas caso tenham como consequência a felicidade. Ronaldo Porto Macedo Junior define o utilitarismo como um "tipo de teoria ética consequencialista, visto que avalia uma ação (ou regra) unicamente em função de suas consequências". 97

Anne Stubbs apresenta ainda dois tipos de consequencialismo utilitarista, "rule and act utilitarism". Segundo a autora, as duas concepções concordam que ações devem ser julgadas pelas suas consequências. A primeira, no entanto, interpreta ações como tipos de ações. A segunda, como ações particulares. Para entender melhor, o consequencialismo do tipo rule, ao contrário do segundo, não admitiria que se considerassem as consequências particulares na tomada de decisão moral ou de julgamento, mas apenas as consequências analisadas universalmente. ${ }^{98}$

Explica Tim Mulgan que na avaliação consequencialista do utilitarismo rule uma ação é moralmente correta apenas se é suportada por um conjunto de regras cujo cumprimento por todos resultaria em consequências ao menos boas em relação a outras ações e seus resultados possíveis. ${ }^{99}$

\footnotetext{
${ }^{94}$ STUART MILL, John. Utilitarismo. Trad. Rita de Cássia G. Neiva. São Paulo: Escala, 2007, p. 22.

${ }^{95}$ POSNER, Richard. Utilitarianism, Economics, and Legal Theory, in The Journal of Legal Studies. Vol. 8, N. 1 (jan. 1979). Disponível em: 〈http://www.jstor.org/stable/724048>. Acesso em: 1.2.2012, p. 111.

${ }^{96}$ Muito embora Amartya Sen defenda que pelo menos um tipo de utilitarismo poderia propor moralidades não consequencialistas. Mas Sen reconhece que o utilitarismo é tipicamente combinado com diversas formas de consequencialismo. SEN, Amartya. Utilitarism and Welfare, in DARWALL, Stephen (org.). Consequentialism. Oxford: Blackwell Publishing, 2003, p. 261.

${ }^{97}$ MACEDO JUNIOR, Ronaldo Porto. Ensaios de Teoria do Direito. São Paulo: Saraiva, 2013, p. 226.

98 STUBBS, Anne. The Pros and Cons of Consequentialism.Philosophy. Vol. 56, $\mathrm{n}^{\mathbf{0}}$ 218, Cambridge University Press, 1981.Disponível em: <http://www.jstor.org/stable/3750884>. Acesso em 1\%/2/2012, p. 498.

${ }^{99}$ MULGAN, Tim. The Demands of Consequentialism. Oxford: Oxford University Press, 2001, p. 53.
} 
Esse tipo de consequencialismo, portanto, exige, para considerar ações corretas, a ideia de que se todos praticam a mesma ação, as consequências devem ser boas, enquanto na avaliação do act utilitarism, apenas as consequências individuais da ação importariam para avaliar as ações.

O critério consequencialista no utilitarismo é tido como juízo de avaliação sobre as ações humanas. As ações mais úteis seriam aquelas que produzem as consequências mais desejáveis.

Cristiano Carvalho estabelece algumas diferenças entre o utilitarismo e o consequencialismo. Afirma que enquanto este se preocupa em analisar consequências sem definir substancialmente quais devam ser elas, no utilitarismo os resultados desejados seriam conhecidos previamente: "uma ação é moralmente correta se o seu resultado alcança a maior satisfação possível para o maior número de pessoas". ${ }^{100}$ Deve-se observar, entretanto, que não é que o utilitarismo seja divergente do consequencialismo, apenas o consequencialismo tem seu "conteúdo" preenchido por certos valores a depender da teoria que o utilize. O consequencialismo, falando em sentido amplo, não teria um conteúdo específico para o tipo de consequência a ser produzida. Os vários tipos de consequencialismo proporão justamente esse conteúdo.

As críticas que podem ser feitas ao consequencialismo nessa perspectiva são mais voltadas à própria natureza do utilitarismo, do que propriamente à escolha das consequências como critério.

O utilitarismo é criticado por desprezar, em grande medida, os aspectos deontológicos, isto é, a decisão jurídica boa seria apenas aquela que maximiza o bem, independentemente do que o direito efetivamente estabeleça. Um tipo moderado de utilitarismo pode propor que, uma vez estabelecidas regras claras sobre o caso, critérios utilitaristas devem servir mais ao legislador do que ao juiz.

Essa noção será importante para se fixar a ideia de que as decisões judiciais devem avaliar não apenas consequências ou efeitos particulares da decisão, o que normalmente se entende por sua eficácia jurídica, mas os efeitos gerais e universais de cada decisão. Ou seja, se cada juiz decidir da mesma forma, as consequências para o ordenamento devem continuar vantajosas a fim de que a decisão seja avaliada como correta, ou melhor, válida.

${ }^{100}$ CARVALHO, Cristiano. Teoria da Decisão Tributária. São Paulo: Saraiva, 2013, p. 86. 


\subsection{Consequencialismo no pragmatismo e na análise econômica do direito}

Rorty, utilizando a fórmula de William James, afirma que: "Se esse debate não tem incidência prática, então ele também não deve ter incidência filosófica". ${ }^{101} \mathrm{O}$ pragmatismo é uma espécie de ramo da filosofia que procura observar apenas fenômenos que tenham incidência prática, e tem enorme influência nos sistemas jurídicos anglosaxões.

O método de investigação pragmático teria como objetivo inicial afastar disputas metafísicas, que gerariam debates intermináveis. ${ }^{102}$ William James afirma que os debates relevantes para o método pragmático seriam aqueles que respondessem à seguinte pergunta: "sob que aspectos o mundo seria diferente se essa alternativa ou aquela fosse verdadeira?" E completa: "Se não posso achar nada que o tornasse diferente, então a alternativa não tem sentido". 103

Aproximando as teorias utilitaristas das pragmáticas, MacCormick diz que as primeiras sustentam que os supostos princípios da obediência e do engajamento seriam subordinados ao princípio da utilidade, tendo em vista que eles dependem também do julgamento sobre o que é melhor levando tudo em consideração. ${ }^{104}$ Aparentemente essa expressão "tudo em consideração", do inglês "all things considered", é comum tanto ao utilitarismo quanto ao pragmatismo, no sentido de que a decisão deve levar em conta todos os aspectos possíveis e acessíveis ao decisor.

O pragmatismo jurídico, decorrente da corrente filosófica pragmática, seria incentivado nos EUA pela falta de regulamentação pela Constituição da maioria dos modernos problemas legais. ${ }^{105}$ Isso leva a questionar o papel de teorias pragmatistas no Brasil, onde a Constituição Federal desempenha um papel analítico no trato dos problemas jurídicos, deixando menor espaço para o uso de interpretações criativas ou flexíveis. ${ }^{106}$

\footnotetext{
${ }^{101}$ RORTY, Richard. Para Que Serve a Verdade? Trad. Antonio Carlos Olivieri. São Paulo: Editora Unesp, 2008, p. 55.

102 JAMES, William. Pragmatismo. Trad. Jorge Caetano da Silva. São Paulo: Martin Claret, 2006, p. 44.

${ }^{103}$ Idem, p. 45.

${ }^{104}$ MACCORMICK, Neil. Pratical Reason in Law and Morality. Oxford: Oxford University Press, 2008, p. 107.

${ }^{105}$ POSNER, Richard. Law, Pragmatism, and Democracy. Cambridge/London: Harvard University Press, 2003, p. 64.

106 Pode-se dizer que as teorias construídas no Common Law pressupõem uma maior liberdade do juiz na construção da decisão do que as teorias criadas na tradição brasileira, por exemplo.
} 
As críticas feitas ao pragmatismo são no sentido de que esse tipo de teoria mostrar-se-ia contrário à própria teorização e levaria o juiz a desprezar o direito preestabelecido para considerar apenas o caso concreto. Em resposta a essas críticas, Posner afirma que seriam falácias, tanto que o pragmatismo implicaria um julgamento ad hoc, porquanto seria hostil a todo tipo de teoria; defende que, diversamente, o pragmatismo abriria o direito a invasões de outras áreas e seria contrário a teorias inúteis e meramente formalistas. ${ }^{107}$ As teorias, de acordo com esta corrente de pensamento, devem estar vinculadas à realidade. Daí por que o pragmatismo propõe a mudança no questionamento: “estou descrevendo o objeto em sua realidade ou apenas sua aparência?" para "estou usando a melhor descrição possível para a situação em que me encontro?"108

Mas a relevância do pragmatismo para o consequencialismo evidencia-se desde sua origem. William James afirma que "o método pragmático nesses casos é tentar interpretar cada noção traçando as suas consequências práticas respectivas". ${ }^{109}$ É da natureza das teorias pragmatistas traçar possíveis consequências, seja para teorias, seja para decisões, e levar em consideração esses resultados previstos ou previsíveis, para atuar. ${ }^{110}$ Flavianne Nóbrega confirma as aspirações consequencialistas do pragmatismo em suas origens, que tem a atenção às consequências concebíveis no futuro, "como um agir criativo que dirige seu olhar para o futuro (foward-looking)". 111

Posner afirma ter o pragmatismo jurídico uma elevada preocupação com fatos e consequências, e uma menor com conceitos e generalizações. ${ }^{112}$ Aponta Posner, no entanto, uma diferença entre o consequencialismo e o pragmatismo, que residiria no fato de que, enquanto o consequencialismo estaria preocupado com as melhores consequências (best consequences), o pragmatismo se fundaria na decisão mais razoável (reasonableness). Porém, apesar de os pragmatistas não se considerarem consequencialistas, estariam mais próximos a estes do que aos deontologistas. ${ }^{113}$

\footnotetext{
${ }^{107}$ POSNER, Richard. Law, Pragmatism, and Democracy. Cambridge/London: Harvard University Press, 2003, p. 76 a 80.

${ }^{108}$ CATÃO, Adrualdo de Lima. Decisão Jurídica e Racionalidade. Maceió: Edufal, 2007, p. 24.

${ }^{109}$ JAMES, William. Pragmatismo. Trad. Jorge Caetano da Silva. São Paulo: Martin Claret, 2006, p. 44.

${ }^{110}$ Embora a consideração das consequências não seja a única preocupação do pragmatismo no direito, é um dos pontos centrais.

${ }^{111}$ NÓBREGA, Flavianne F. B. Um Método para a Investigação das Consequências: a lógica pragmática da abdução de C. S. Pierce aplicada ao direito. João Pessoa: Ideia, 2013, p. 19.

${ }^{112}$ POSNER, Richard. Law, Pragmatism, and Democracy. Cambridge/London: Harvard University Press, 2003 , p. 59.

${ }^{113}$ Idem, p. 65.
} 
No pragmatismo, portanto, o estímulo ao uso das consequências seria derivado da ideia de que o juiz deve criar a decisão tendo em vista todas as coisas consideradas no caso concreto, em detrimento do que foi previsto.

Pragmatistas pensam que se o juiz deve decidir, por exemplo, sobre uma questão constitucional acerca da possibilidade de crianças imigrantes estudarem de forma gratuita em escolas públicas, ele deveria estudar ou ter conhecimento sobre educação, imigração, finanças públicas e demais tópicos relacionados à decisão. ${ }^{114}$

No julgamento da medida cautelar na Ação Direta de Inconstitucionalidade 4.467, na qual o Supremo Tribunal Federal dispôs a não obrigatoriedade da exigência de dois documentos para a votação na eleição de 2010, o argumento necessário e suficiente para a resolução da questão é que a exigência de ambos os documentos, titulo de eleitor e mais um documento com foto, resulte na exclusão do processo democrático das pessoas mais humildes, especialmente em regiões onde o acesso a tais documentos é mais dificultoso.

É possível fundamentar tal decisão no Princípio Democrático ou na regra do voto universal, mas a razão pela qual não se podem exigir dois documentos é baseada no uso de consequências.

De fato, a interpretação pragmatista exigiria decidir da forma mais razoável, levando todas as coisas em consideração. ${ }^{115}$ Segundo Posner, "todas as coisas consideradas" incluiriam não apenas as consequências específicas das decisões, até onde elas possam alcançar, como também os textos legais, a preservação dos valores do império do direito, além de considerações prudenciais e psicológicas de enumeração infinita. ${ }^{116}$

"No pragmatismo jurídico, a reconciliação entre dogmática e consequencialismo é opcional e se subordina à visão do decisor sobre os interesses sociais relevantes para o caso". ${ }^{117}$ Por dogmática o autor refere-se à visão deontológica de imputação do dever-ser, não a qualquer dogmática mais ampla. Assim, pode-se entender que não há necessariamente na análise consequencialista pelo pragmatismo jurídico uma negação completa dessa dogmática, mas uma liberdade talvez mais ampla do juiz na análise dentro da moldura normativa.

\footnotetext{
${ }^{114}$ Idem, p. 79.

${ }^{115}$ Idem, p. 64

${ }^{116}$ Idem, Ibidem.

${ }^{117}$ SCHUARTZ, Luis Fernando. Consequencialismo jurídico, racionalidade decisória e malandragem, in MACEDO JR, Ronaldo Porto \& BARBIERI, Catarina H. Cortada. Direito e Interpretação: racionalidades e instituições. São Paulo: Saraiva, 2011, p. 406.
} 
Posner ressalta a diferença entre as consequências no pragmatismo e no utilitarismo afirmando que, apesar da ênfase nas consequências, o pragmatismo legal não é uma forma de consequencialismo, como conjunto de doutrinas, especialmente utilitaristas, que valoram ações pelo valor de suas consequências. A melhor ação é aquela que traz as melhores consequências, mesmo porque o juiz nem sempre estaria autorizado a avaliar todas as consequências de sua decisão. ${ }^{118}$

As teorias utilitaristas e pragmáticas, apesar de divergirem em seus pressupostos ou bases teóricas, no que diz respeito ao uso de consequências parecem convergir, pois se assemelham em vários aspectos e apresentam, à primeira vista, poucos pontos discordantes.

As consequências, assim como os efeitos econômicos, seriam centrais para o pragmatismo. ${ }^{119}$ Daí autores como Posner poderem ser classificados como pragmatistas vinculados às teorias de análise econômica do direito.

Com relação ao tema do tópico anterior, Richard Posner afirma que há diferenças substanciais entre a proposta utilitarista para o direito e a proposta da análise econômica, e conclui que esta pode trazer critérios mais seguros e bem fundamentados que aquela. ${ }^{120}$ Em defesa da análise econômica, Posner afirma que esta teria um campo intelectual distinto do utilitarismo no direito, com conceitos, metodologia e vocabulário técnico diversos. ${ }^{121}$

A análise econômica do direito assume que pessoas são racionais e pretendem maximizar suas satisfações. ${ }^{122}$ E pretende, segundo Paulo Caliendo, não apenas descrever o direito com conceitos econômicos, como apresentar elementos econômicos para a formação da teoria jurídica. A proposta, portanto, é a de analisar o direito sob a perspectiva de teorias econômicas, como a teoria dos jogos e a teoria das escolhas públicas, especialmente sobre a eficiência das decisões. ${ }^{123}$

Em artigo inaugural sobre a análise econômica do direito, Ronald Coase afirma que seria desejável que as cortes entendessem as consequências econômicas que suas

\footnotetext{
${ }^{118}$ POSNER, Richard. Law, Pragmatism, and Democracy. Cambridge/London: Harvard University Press, 2003, p. 60.

${ }^{119}$ Idem, p. 78.

${ }^{120}$ POSNER, Richard. Utilitarianism, Economics, and Legal Theory, in The Journal of Legal Studies. Vol. 8, N. 1 (jan. 1979). Disponível em: 〈http://www.jstor.org/stable/724048>. Acesso em: 1.2.2012, p. 103.

${ }^{121}$ Idem, p. 105.

${ }^{122}$ POSNER, Richard. The Economics of Justice. Cambridge: Harvard University Press, 1981, p. 1.

${ }^{123}$ CALIENDO, Paulo. Direito Tributário e Análise Econômica do Direito: uma visão crítica. Rio de Janeiro: Elsevier, 2009, p. 15.
} 
decisões acarretam, desde que produzissem a menor incerteza jurídica possível. ${ }^{124}$ A partir dos primórdios da análise econômica do direito, portanto, observa-se uma centralidade da preocupação consequencialista.

Ronaldo Porto Macedo Junior dedica um capítulo à análise do pensamento de Richard Posner em seu livro "Ensaios de Teoria do Direito", e conclui ser possível observar uma evidente mudança na orientação, do utilitarismo ou de um consequencialismo eficientista, ${ }^{125}$ para uma visão pragmática da Análise Econômica do Direito. $^{126}$

$\mathrm{Na}$, chamada por Ronaldo Macedo, primeira fase da análise econômica do direito, Posner defenderia ser possível deduzir as características formais básicas do direito da teoria econômica. ${ }^{127} \mathrm{Na}$ segunda fase, enormemente influenciada por Posner, teria havido uma flexibilização da rigidez dos modelos econômicos, utilizando-se a economia de forma mais pragmática. ${ }^{128}$

Apesar das mudanças na segunda geração, haveria alguns pontos de acordo. Seriam premissas da análise econômica do direito: a pretensão comportamental, fundada na ideia de que a economia poderia fornecer uma teoria útil para a predição de comportamentos como a oferecida pela teoria dos jogos e pela teoria da escolha racional; ${ }^{129}$ a pretensão normativa, no sentido de que o direito deve ser eficiente; as pretensões fatual e genética, que suporiam ser o Common Law eficiente, ou que selecionasse regras eficientes, caso admitido que nem todas assim o fossem. ${ }^{130}$

Richard Posner, na segunda fase da análise econômica do direito, defenderia "uma visão consequencialista (foward-looking), experimental e pragmática e, num certo sentido, baseada no senso comum, mais do que numa teoria estrutural ou fundacional". ${ }^{131}$

\footnotetext{
${ }^{124}$ COASE, Ronald H.The Problem of Social Cost.The Journal of Law \& Economics.Vol. III. 1960, p. 19.

${ }^{125} \mathrm{O}$ autor esclarece que se refere a um consequencialismo orientado para a produção da eficiência econômica.

${ }^{126}$ MACEDO JUNIOR, Ronaldo Porto. Ensaios de Teoria do Direito. São Paulo: Saraiva, 2013, p. 226.

${ }^{127}$ Apud MACEDO JUNIOR, Ronaldo Porto. Ensaios de Teoria do Direito. São Paulo: Saraiva, 2013, p. 230.

${ }^{228}$ MACEDO JUNIOR, Ronaldo Porto. Ensaios de Teoria do Direito. São Paulo: Saraiva, 2013, p. 233.

${ }^{129}$ Cristiano Carvalho expõe em livro recente sobre a teoria da escolha racional, definindo seu objetivo: "modelar matematicamente as escolhas dos indivíduos" e afirma que é um paradigma dominante na ciência econômica. Afirma ainda que seriam pontos de partida dessa teoria: 1) os indivíduos são autointeressados, buscado maximizar seu bem-estar; 2) os indivíduos realizam escolhas consistentes com as informações de que dispõem; 3) os indivíduos reagem a incentivos. Por fim, admite o autor que "devemos partir deles sem questioná-los, considerando apenas que para fins analíticos do comportamento humano eles são robustos o suficiente para separar aquilo que é o elemento previsível do comportamento humano e, assim, permitir modelos descritivos". CARVALHO, Cristiano. Teoria da Decisão Tributária. São Paulo: Saraiva, 2013, p. 56.

${ }^{130}$ MACEDO JUNIOR, Ronaldo Porto. Ensaios de Teoria do Direito. São Paulo: Saraiva, 2013, p. 235.

${ }^{131}$ Idem, p. 237.
} 
Para Carla Faralli:

Posner propõe que, ao abordar os problemas jurídicos, se levem em conta os efeitos das soluções propostas - a curto e a longo prazo, seja para os indivíduos, seja para o sistema - através de pesquisas empíricas sobre os custos/benefícios e do critério da racionalidade meios/fins. ${ }^{132}$

Uma das críticas à análise consequencialista a que se propõe a análise econômica é a de que não se tem condições de saber o suficiente para determinar empiricamente e comparar normativamente as consequências globais relacionadas à adoção de uma ou outra decisão. ${ }^{133}$

Luis Fernando Schuartz critica o pensamento consequencialista desenvolvido nas decisões judiciais que, orientadas nas próprias consequências, seriam construídas sob incerteza subjetiva. ${ }^{134}$ Além disso, poderia ser constatado no futuro que a decisão não produziu os efeitos desejados ou que não era adequada para produzir os efeitos pretendidos, e essa constatação de nada serviria, ou ao menos seria questionável. ${ }^{135}$

O problema não está na consistência e robustez das teorias ou do arsenal de conceitos que as acompanha nas proposições mais substantivas das análises econômicas do direito, mas no acesso às informações necessárias para garantir às decisões a satisfação das condições de adequação que lhe são impostas por tais teorias e conceitos. ${ }^{136}$

A análise econômica do direito propõe, portanto, uma análise consequencialista probabilística, que muitas vezes ou sempre escapará às habilidades de um juiz comum, sem apoio técnico e especializado para decidir. Isso não quer dizer que em algumas ou muitas situações o juiz não possa se auxiliar de dados econômicos, sociais, para argumentar numa decisão.

O Conselho Nacional de Justiça - CNJ propôs, por exemplo, a criação de varas especializadas de fazenda pública especializadas em questões relacionadas à saúde. ${ }^{137}$ Certamente os juízes que serão designados para essas funções poderão ter uma

\footnotetext{
${ }^{132}$ FARALLI, Carla. A Filosofia Contemporânea do Direito: temas e desafios. São Paulo: Martins Fontes, 2006, p. 36.

${ }^{133}$ SCHUARTZ, Luis Fernando. Consequencialismo jurídico, racionalidade decisória e malandragem, in MACEDO JR, Ronaldo Porto \& BARBIERI, Catarina H. Cortada. Direito e Interpretação: racionalidades e instituições. São Paulo: Saraiva, 2011, p. 407.

${ }_{134}^{134}$ Idem, p. 389.

135 Idem, p. 391.

136 Idem, p. 389 e 390.

${ }^{137}$ CONSELHO NACIONAL DE JUSTIÇA. CNJ recomenda especialização de varas de fazenda pública para tratar de questões de saúde. Disponível em: < http://www.cnj.jus.br/noticias/cnj/25761:cnjrecomenda-aos-tribunais-a-criacao-de-varas-para-saude>. Acesso em 10.01.2014.
} 
compreensão profunda sobre o tema, especialmente quando auxiliados por outros profissionais, como médicos e enfermeiros, que produzam laudos sobre os temas a decidir.

Bruno Salama afirma que a economia, por outro lado, não fornece uma guia ético adequado para o direito. ${ }^{138}$ No sentido de que a economia não consegue fornecer os critérios para decidir as questões jurídicas, como pretende a análise econômica do direito.

Mas propõe Salama que, apesar disso, a economia poderia "fornecer ferramentas úteis para iluminar a relação entre meios jurídicos e fins normativos. Desse modo, a economia permite um tipo de crítica jurídica que já se tornou imprescindível nos dias de hoje.

Os critérios da análise econômica do direito não são, portanto, apesar de criticáveis sob alguns aspectos, inúteis ao direito. No entanto, a proposta de Neil MacCormick, apesar de mais tímida, é mais vinculada aos critérios alimentados pelo próprio direito. Traz uma racionalidade mais segura do ponto de vista jurídico, portanto. Antes de tratar do assunto, resta anotar o que aproxima o consequencialismo do direito, diante das diversas teorias até aqui apresentadas.

\subsection{Consequencialismo e Direito}

Luis Fernando Schuartz define o consequencialismo do ponto de vista jurídico como "qualquer programa teórico que se proponha a condicionar, ou qualquer atitude que condicione explícita ou implicitamente a adequação jurídica de uma determinada decisão judicante à valoração das consequências associadas a ela e às suas alternativas". ${ }^{139}$

O conceito é muito bom, porquanto abrangente em relação aos vários tipos de consequencialismos encontrados no direito, desde os que defendem uma ampla e irrestrita utilização de razões consequencialistas para decidir, até os que valoram o elemento consequencialista implicitamente.

São muitas as dificuldades para adequar razões consequencialistas ao direito. Entretanto,

${ }^{138}$ SALAMA, Bruno M. A História do Declínio e Queda do Eficientismo na Obra de Richard Posner, in LIMA, Maria Lúcia L. M. (coord.). Agenda Contemporânea: direito e economia. São Paulo: Saraiva, 2012, p. 319.

${ }^{139}$ SCHUARTZ, Luis Fernando. Consequencialismo jurídico, racionalidade decisória e malandragem, in MACEDO JR, Ronaldo Porto \& BARBIERI, Catarina H. Cortada. Direito e Interpretação: racionalidades e instituições. São Paulo: Saraiva, 2011, p. 383 e 384. 
por mais que não possamos ou não queiramos identificá-las, decisões judiciais têm consequências, reconhecidamente. Exigir dos juízes que se abstenham, na justificação das suas decisões, de considerar as consequências associadas a elas e às suas alternativas, significa reservar exclusivamente aos órgãos do Poder Legislativo e do Poder Executivo essa possibilidade. ${ }^{140}$

Diante das principais teorias vistas nos tópicos passados deste capítulo, pode-se observar que as discussões sobre o uso de argumentos consequencialistas no direito giram em torno de algumas questões. Com base em argumentos fundados em consequências, poderia o juiz suprir as lacunas do ordenamento ou mesmo desprezar o texto legislativo de forma a considerar os efeitos futuros de sua decisão? $\mathrm{O}$ uso de consequências no direito pressupõe um modelo no qual o juiz também é considerado criador da norma jurídica, assumindo o texto legal um papel diverso do tradicional? As teorias que defendem o uso de argumentos consequencialistas no direito vão discordar justamente no que diz respeito aos limites entre a norma e as consequências.

Podem-se classificar tais divergências: i) se argumentos consequencialistas devem ser usados em qualquer decisão ou apenas em casos difíceis; ii) se argumentos consequencialistas podem ser usados apenas quando não há normas tratando do caso, ou quando, por exemplo, há uma regra específica tratando da matéria; iii) no conflito entre argumentos consequencialistas e argumentos deontológicos, quais devem prevalecer; iv) que tipo de argumento consequencialista pode ser considerado no direito, apenas consequências jurídicas podem ser consideradas, ou também consequências econômicas, sociais etc.; v) como aferir o peso das consequências para cada caso (e a questão da capacidade do juiz para decidir sobre tais pesos). ${ }^{141}$

Sobre o ponto (i), o uso de argumentos fundados nas consequências muitas vezes é defendido apenas quando não há uma regulamentação específica pelo ordenamento jurídico. Posner, por exemplo, afirma que quando as consequências não são catastróficas ou absurdas, o mais sensato seria seguir a regra ou o contrato, com vistas a proteger as expectativas e preservar a linguagem ordinária como meio efetivo da comunicação legal. ${ }^{142}$

\footnotetext{
${ }^{140}$ Idem, p. 396 e 397.

${ }^{141}$ Embora os problemas referentes a tais divergências sejam tratados neste tópico, as opções tomadas pela tese serão mais bem expostas no fim do próximo capítulo, que explorará em primeiro lugar as orientações de Neil MacCormick.

${ }^{142}$ POSNER, Richard. Law, Pragmatism, and Democracy. Cambridge/London: Harvard University Press, 2003, p. 82.
} 
Numa posição próxima à de Posner, que afirmou acima ser o consequencialismo aplicável apenas em situações catastróficas, sustenta Cristiano Carvalho que apenas em "casos difíceis" posições consequencialistas deveriam ser empregadas. ${ }^{143}$ MacCormick, como se verá no próximo capítulo, também não defende o uso de argumentos consequencialistas em qualquer caso, diferentemente do que será proposto no ponto 3.5 do próximo capítulo deste trabalho.

Em relação ao ponto (ii), a primeira dificuldade é estabelecer onde há normatização exata sobre o caso e qual o espaço de anomia, afinal, a legitimidade do juiz para decidir acerca das questões que não trazem respostas deontológicas muito claras.

É de se considerar, nesse ponto, a proposta retórica; nesta, a persuasão do juiz não necessariamente se dá pelo argumento deontológico ou pelo consequencialista, isto é, não há a inevitável exclusão de um pelo outro. Possivelmente o conjunto textual, a combinação de argumentos, é que trará a persuasão, não sendo necessário afastar o argumento consequencialista de plano, quando constatada pela interpretação a existência de norma sobre o caso.

Cristiano Carvalho procura adequar a análise consequencialista à deontológica (iii). Afirma que aquela poderia se adequar a esta, colocando o consequencialismo a serviço da deontologia no contexto jurídico, indicando para tal fim o seguinte caminho: “opta-se pelo guia deontológico na aplicação do direito apenas porque em uma análise custo-benefício é mais vantajoso aproveitar soluções prontas e testadas do que procurar soluções novas e talvez inseguras no tocante aos resultados". ${ }^{144}$ Segundo o autor, seria uma estratégia "consequencialista" seguir o direito deontologicamente, pressupondo que este teria soluções mais benéficas, como para a segurança jurídica, por exemplo.

O conflito entre argumentos consequencialistas e deontológicos, no entanto, é um embate natural que os tribunais resolvem também pelo critério da persuasão. Os melhores argumentos em cada caso tendem a vencer o debate, visto que o nosso sistema exige um destaque final ao aspecto silogístico deontológico, expresso na fundamentação da decisão que cria a incidência de uma norma sobre o fato regulado.

A grande dificuldade na conciliação entre o uso de critérios consequencialistas nas decisões judiciais e a dogmática jurídica tradicional positivista seria, segundo Luis Fernando Schuartz, a possível reestruturação da norma enquanto típica manifestação do

\footnotetext{
${ }^{143}$ CARVALHO, Cristiano. Teoria da Decisão Tributária. São Paulo: Saraiva, 2013, p. 92.

${ }^{144}$ Idem, p. 91.
} 
deôntico de "Se X, então deve ser Y", para outra estrutura na qual as consequências são relevantes. $^{145}$

O ponto (iv) é um ponto sensível à tese, e será mais bem trabalhado no item 3.5 do próximo capítulo. Neste, a proposta de Neil MacCormick que será avaliada é justamente a de sugerir um consequencialismo essencialmente jurídico, em que os argumentos de tal natureza poderiam ser distintos dos argumentos consequencialistas de outra natureza, como a econômica ou a social.

O último critério (v), em relação à aferição de peso dos argumentos consequencialistas em cada caso, é algo que realmente não faria sentido fixar previamente a cada decisão. Não é possível criar uma tabela com o peso de cada argumento, tendo em vista que cada um pode ser aferido diferentemente por cada juiz em cada caso. Quanto ao segundo aspecto, a questão da capacidade do juiz para decidir sobre tais pesos, também no próximo capítulo se fixará melhor a ideia de que consequências econômicas e sociais são de difícil previsão. Portanto, a proposta de consequencialismo jurídico deve ser menos ligada a prognósticos e mais à ideia de que consequências aquela decisão traz para o direito.

Um dos críticos do consequencialismo aplicado ao direito no Brasil é Luis Fernando Schuartz. Em artigo referência sobre o tema, o autor expõe três tipos comuns de consequencialismo, que na verdade são estratégias retóricas de construção argumentativa diante do direito tradicional pelo intérprete. Seriam o consequencialismo festivo, o militante e o malandro. A diferença entre os tipos se daria, segundo o autor, pelo grau de respeito ao precedente e ao raciocínio lógico-dedutivo.

O primeiro tipo, festivo, "advoga uma ampla desdiferenciação entre aplicação do direito e formulação de políticas públicas" e uma "apropriação superficial e seletiva da literatura norte-americana de análise econômica do direito". O consequencialismo do tipo militante se caracterizaria "por não se deter diante das regras do direito positivo e não se preocupar em reestruturar as suas referências normativas”. Seria mais alinhado à tradição dogmática do que o festivo, porém com análise superficial de técnicas como a ponderação de princípios, sem, por outro lado, estar amparado em métodos científicos explorados, mesmo que superficialmente, pelo consequencialismo festivo. Por fim, por malandragem o autor entende ser uma estratégia argumentativa que recorre à ordem jurídica para promover

${ }^{145}$ SCHUARTZ, Luis Fernando. Consequencialismo jurídico, racionalidade decisória e malandragem, in MACEDO JR, Ronaldo Porto \& BARBIERI, Catarina H. Cortada. Direito e Interpretação: racionalidades e instituições. São Paulo: Saraiva, 2011, p. 404. 
a desordem. Isto é, “a decisão pretendida por intermédio da construção de conceitos e distinções que conduzam à referida decisão e a façam aparecer como desde sempre juridicamente admissível e adequada ao caso concreto". ${ }^{146}$

O consequencialismo malandro seria a forma mais sofisticada do consequencialismo jurídico, pois, segundo Luis Fernando Schuartz requer um amplo conhecimento de teoria do direito e da dogmática jurídica tradicionais. Pode ser visto como um canal de produção de inovação no direito, "dado que se orienta na solução de problemas jurídicos específicos e concretos”, e, por fim, pela pretensão de generalidade que reflete exigências de igualdade e justiça formal. ${ }^{147}$

Em todos os casos identificados por Schuartz estaria presente a "rejeição de decisões resultantes da aplicação de regras de direito positivo, usualmente leis ordinárias". ${ }^{148}$

No entanto, é preciso discordar das conclusões apresentadas pelo autor. Embora seja possível identificar os três tipos de uso de argumentos consequencialistas apontados, acredita-se ser possível pensar num consequencialismo jurídico. Que não fuja dos critérios tradicionais de justificação, mas que faça parte da interpretação das normas e, dentro da perspectiva retórica, seja persuasivo aos juízes e ao auditório universal.

O próximo capítulo irá tratar da última teoria sobre consequencialismo, a de Neil MacCormick. Esta merece destaque não apenas pela importância do autor para o tema, como por ter tal autor criado o conceito de consequencialismo jurídico que servirá de base para o desenvolvimento da tese.

\footnotetext{
${ }^{146}$ Idem, p. 410-415.

${ }^{147}$ Idem, p. 415.

${ }^{148}$ Idem, 2011, p. 417.
} 


\section{CAPÍTULO 3. RETÓRICA E O CONSEQUENCIALISMO JURÍDICO NA TEORIA DE NEIL MACCORMICK}

3.1 Retórica e argumentação jurídica em MacCormick

3.2 Regra de reconhecimento, o silogismo jurídico e a argumentação dedutiva

3.3 Universalização das decisões em MacCormick

3.4 Julgando com o uso de consequências

$3.5 \mathrm{O}$ argumento consequencialista jurídico

O objetivo deste capítulo é situar a teoria de Neil MacCormick na Teoria do Direito, especificamente nos pressupostos da defesa de uma análise das consequências jurídicas das decisões no contexto da argumentação jurídica.

$\mathrm{O}$ tratamento à parte dado ao autor se deve pela sua importância à tese, por produzir uma proposta consistente de análise das consequências, centrada na argumentação jurídica.

Nem todos os aspectos de sua teoria serão analisados, mas será feito um esforço para entender quais os pressupostos de uma decisão judicial, seja no common law, seja no civil law, com ênfase no aspecto retórico da argumentação jurídica, essencial para a tese, identificando esse foco do autor escocês como referência teórica, embora com reservas.

Sua explanação sobre argumentação jurídica, segundo o próprio MacCormick, é considerada essencialmente hartiana, ou ao menos compatível com ela. ${ }^{149}$ Ele parte, por exemplo, de um dos principais fundamentos da teoria de Hart que é o da regra de reconhecimento.

MacCormick, segundo Atienza, procura harmonizar a razão prática, expressa na ideia de universalizabilidade, com o reconhecimento da impossibilidade de regras bastarem ao raciocínio jurídico, e assim construir uma teoria que seja tanto descritiva ${ }^{150}$

\footnotetext{
${ }^{149}$ MACCORMICK, Neil. Argumentação Jurídica e Teoria do Direito. São Paulo: Martins Fontes, 2006, p. XVII.

${ }^{150}$ Com relação aos termos "descritiva" e "normativa", entende-se que o autor esteja se referindo ao fato de que a doutrina pode escrever teses que expliquem como são o direito, e teses que definam como o direito deve ser. Não se confunde com a noção de que a doutrina não poderia ser normativa em razão de que seus textos não prescrevem as condutas, apenas as normas extraídas dos textos legais.
} 
quanto normativa, que dê conta de aspectos dedutivos e não dedutivos da argumentação jurídica. $^{151}$

A visão do autor escocês neste capítulo irá se desenvolver por um caminho lógico que insira o debate consequencialista. Em primeiro lugar, caracteriza-se o direito como disciplina argumentativa e retórica e verifica-se a posição de MacCormick nesse contexto, ao discutir o silogismo jurídico e o aspecto dedutivista dessa argumentação. Em seguida, demonstra-se um dos aspectos centrais da teoria, a necessidade de universalização das decisões, fundada juridicamente nos princípios da justiça e da igualdade. Finalmente, averiguam-se as possibilidades e limites do uso de argumentos consequencialistas, apontando os caminhos que se pretende seguir na segunda parte da tese.

\subsection{Retórica e argumentação jurídica em MacCormick}

No primeiro capítulo deste trabalho foram expostas as principais características da retórica como método de análise das decisões judiciais. MacCormick se diz filiado a essa tradição retórica na argumentação jurídica, por isso se faz necessário debater os pontos postos pelo autor que o credenciam como tal.

Neil MacCormick reconhece a importância de se observar o direito como disciplina argumentativa. Ele situa a argumentação jurídica como ramo da argumentação prática, que por sua vez consistiria na "aplicação da razão por parte dos seres humanos para decidir qual é a forma correta de se comportarem em situações onde haja escolha". ${ }^{152}$

$\mathrm{O}$ autor explicita que o processo de aplicar normas é fundamental para a atividade jurídica e que estudar a estrutura racional desse processo é crucial para explanar a natureza da argumentação jurídica como ramo da argumentação prática. ${ }^{153} \mathrm{Um}$ dos pressupostos da argumentação jurídica, inclusive a defendida por MacCormick, é o de que as decisões devem ser racionais, com razões para cumprir o requisito da justificação.

A aplicação das normas aos casos práticos, portanto, pressupõe a criação de uma argumentação que embase e justifique ser aquela decisão a melhor possível ou a mais

\footnotetext{
${ }^{151}$ ATIENZA, Manuel. As Razões do Direito: teorias da argumentação jurídica. $3^{\mathrm{a}}$ ed. Trad. Maria Cristina G. Cupertino. São Paulo: Landy Editora, 2006, p. 119.

${ }^{152}$ MACCORMICK, Neil. Argumentação Jurídica e Teoria do Direito. São Paulo: Martins Fontes, 2006, p. IX.

${ }^{153}$ Idem, Ibidem.
} 
correta para o caso. E o direito exigiria o desenvolvimento das decisões por métodos racionais, nos quais a justificação das decisões tem um papel central.

Segundo Manuel Atienza, para MacCormick tanto a argumentação prática, em geral, quanto a jurídica, em especial, cumprem, essencialmente, uma função justificadora:

Essa função justificadora está presente inclusive quando a argumentação persegue uma finalidade de persuasão, pois só se pode persuadir se os argumentos estão justificados, isto é - no caso da argumentação jurídica se estão de acordo com os fatos estabelecidos e com as normas vigentes. ${ }^{154}$

Sobre o conceito de justificação, MacCormick define ser o ato de demonstrar que algo está certo. ${ }^{155}$ E explica que justificar seria demonstrar que o ato deveria ter sido praticado, da forma e com o conteúdo com que foi praticado, devido às circunstâncias do caso analisado. ${ }^{156}$ Nesse sentido, afirma Perelman que a motivação das sentenças "já não se contenta em mostrar a correção formal, mas se esforça em torná-las convincentes". ${ }^{157}$

MacCormick afirma que a necessidade de justificação das decisões só é atingida quando são encontradas boas razões para se decidir de uma forma, e se essas razões derrotam de algum modo quaisquer outras que possam ser oferecidas alternativamente no caso. ${ }^{158}$

MacCormick, em livro mais recente, afirma serem três os principais requisitos para uma boa razão jurídica: coerência, consistência e consequências. A coerência seria a adequação do caso a algum princípio mais amplo e fundamental do ordenamento jurídico. A consistência estaria relacionada à não contradição da decisão do caso com nenhuma regra jurídica vinculante. E as consequências, que devem ser melhores do que as que

\footnotetext{
${ }^{154}$ ATIENZA, Manuel. As Razões do Direito: teorias da argumentação jurídica. $3^{\mathrm{a}}$ ed. Trad. Maria Cristina G. Cupertino. São Paulo: Landy Editora, 2006, p. 119.

155 "To justify an act is to show that it is right". MACCORMICK, Neil. Rhetoric and the Rule of Law: a theory of legal reasoning. Oxford: Oxford University Press, 2005, p. 98.

156 "To show that it is right is to show that, upon any objective view of the matter, the act ought to have been done, or even had to be done, given the character of the act and the circumstances because of what this is and what these are". Idem, Ibdem.

${ }^{157}$ PERELMAN, Chaïm. Ética e Direito. $2^{\mathrm{a}}$ ed. Trad. Maria Ermantina de A. P. Galvão. São Paulo, 2005, p 557.

158 "The requirement that a decision be justified is met only if there are good reasons for deciding in the particular chosen way, and if these defeat in some way any reasons that can be offered for any alternative disposal of the case". MACCORMICK, Neil. Rhetoric and the Rule of Law: a theory of legal reasoning. Oxford: Oxford University Press, 2005, p. 83.
} 
outras decisões poderiam desencadear, são essencialmente jurídicas, e não probabilísticas. ${ }^{159}$

Ainda sobre a coerência como requisito das decisões judiciais, Tathiane Piscitelli distingue-a em dois tipos com base em Neil MacCormick: a normativa, que se relaciona com a justificação de decisões judiciais no contexto de um sistema jurídico concebido como uma ordem normativa, orientada para a regulação de condutas; e a narrativa, relacionada à justificação das provas e à aferição de conclusões a partir delas. ${ }^{160}$ Billier e Maryoli comentando a teoria de MacCormick afirmam que:

nenhum juiz poderá tomar uma decisão em contradição com as regras válidas e os princípios de um sistema de direito positivo (princípio de consistência); além disso, como afirma Neil MacCormick, sua decisão deve estar em perfeita coerência com os valores e os padrões da ordem jurídica positiva (princípio da coerência). ${ }^{161}$

É possível interpretar, então, que quando MacCormick fala em princípios, quer dizer valores; os princípios enquanto norma seriam parte da consistência, e não da coerência normativa. Mas isso implicaria dizer que o sistema jurídico recepciona valores por outras formas que não seus princípios e regras.

Sobre o papel dos princípios na teoria de MacCormick, Atienza afirma caracterizarem-se como normas gerais que cumprem uma função explicativa e por exercerem uma função positiva, em um papel de justificação. E ao tempo que as regras "tendem a garantir um fim valioso ou algum modelo geral de conduta desejável”, os princípios "exprimem o fim a alcançar ou a desejabilidade do modelo geral de conduta". ${ }^{162}$

Uma parte necessária da justificação da decisão, pois, é mostrar que esta não contraria regras válidas estabelecidas pelo direito, além de demonstrar que é suportada ou embasada por princípios jurídicos positivados.

Mas o ponto conclusivo de uma decisão, segundo MacCormick, quando ainda se sustenta depois de testada a sua consistência e coerência, é que seja avaliada sob

\footnotetext{
${ }^{159}$ MACCORMICK, Neil. Practical Reason in Law and Morality. Oxford: Oxford University Press, 2008, p. 189.

${ }^{160}$ PISCITELLI, Tathiane dos Santos. Interpretação e Justificação no Direito: o requisito da coerência, in SOUZA, Priscila de. Sistema Tributário Brasileiro e Crise Atual. VI Congresso Nacional de Estudos Tributários. São Paulo: Noeses, 2009, p. 990.

${ }^{161}$ BILLIER, Jean-Cassien \& MARYOLI, Aglaé. História da Filosofia do Direito. Barueri: Manole, 2005, p. 405 .

${ }^{162}$ ATIENZA, Manuel. As Razões do Direito: teorias da argumentação jurídica. $3^{\text {a }}$ ed. Trad. Maria Cristina

G. Cupertino. São Paulo: Landy Editora, 2006, p. 130 e 131.
} 
argumentos fundados em consequências. ${ }^{163}$ Contudo, antes de falar sobre tais argumentos, cumpre analisar o modo como MacCormick desenvolve a argumentação jurídica clássica composta pela ideia de dedução e silogismo.

O objeto de estudo do autor escocês busca explicar a natureza da argumentação jurídica como manifestada no processo público de litígios e decisões judiciais referentes a disputas sobre questões de direito, e o processo de raciocínio que é revelado em sentenças publicadas de Tribunais de Justiça. ${ }^{164}$ Pesquisa, desse modo, a argumentação desenvolvida nos tribunais, estudo próprio das teorias da argumentação jurídica.

Manuel Atienza critica a tese de MacCormick no âmbito da teoria da argumentação, no sentido de que:

Ao se concentrar nas decisões dos tribunais superiores, uma concepção como a de MacCormick produz também uma certa distorção no fenômeno jurídico, porque faz com que o aspecto argumentativo da prática jurídica pareça ter uma importância maior do que ele realmente tem. Por outro lado, essa delimitação do campo de investigação explica também o relativo abandono da argumentação com relação aos fatos (os problemas da prova), apesar de eles terem uma importância decisiva na maior parte das decisões jurídicas. Resumindo, poder-se-ia dizer que MacCormick só dá conta de um aspecto bastante parcial da argumentação jurídica. ${ }^{165}$

A mesma crítica pode ser feita a esta tese e a outros trabalhos que tenham como objeto as decisões dos tribunais superiores. Acontece que além de possuírem uma legitimidade maior, por pretenderem unificar os critérios de decisão de um determinado sistema, o objeto tende a ser menor do que o de uma análise das decisões de primeira instância, por exemplo, viabilizando uma pesquisa abrangente.

Perelman ressalta que as jurisdições superiores, em razão da necessidade de unificar as jurisprudências, esforçam-se para convencer as instâncias inferiores de que a solução apontada é a mais conforme ao direito em vigor e a mais adequada aos problemas jurídicos em tela. ${ }^{166}$

\footnotetext{
163 "The conclusive or clinching point of argument when a case still stands open after such testing for consistency and coherence is an argument about consequences in a somewhat different sense than any we have yet considered". MACCORMICK, Neil. Rhetoric and the Rule of Law: a theory of legal reasoning. Oxford: Oxford University Press, 2005, p. 104.

${ }^{164}$ MACCORMICK, Neil. Argumentação Jurídica e Teoria do Direito. São Paulo: Martins Fontes, 2006, p. 9 e 10.

${ }_{165}$ ATIENZA, Manuel. As Razões do Direito: teorias da argumentação jurídica. $3^{\mathrm{a}}$ ed. Trad. Maria Cristina G. Cupertino. São Paulo: Landy Editora, 2006, p. 150.

${ }^{166}$ PERELMAN, Chaïm. Ética e Direito. $2^{\mathrm{a}}$ ed. Trad. Maria Ermantina de A. P. Galvão. São Paulo, 2005, p 567.
} 
De qualquer forma, MacCormick afirma não estar demonstrando verdades sobre argumentação jurídica em todos os campos do mundo, mas restritas ao seu objeto de estudo:

\begin{abstract}
Na medida em que eu seja capaz de explicar meus exemplos específicos em termos de premissas filosóficas mais gerais, meu objetivo será o de oferecer hipóteses sugestivas dignas de serem testadas para verificação de seu valor explanatório em relação a outros sistemas jurídicos, tarefa que exigiria um estudo comparativo fora de meu alcance no momento. ${ }^{167}$
\end{abstract}

Acerca do direito inglês ou escocês, MacCormick afirma que, diferentemente dos sistemas romanos, os tribunais de recursos seguiriam um modelo onde cada um dos diversos juízes normalmente "expõe sob a forma discursiva seu próprio parecer sobre os pontos levantados no caso", de tal modo que os juízes podem "elaborar pontos de vista totalmente diferentes, até mesmo opostos, ao defender a decisão à qual são favoráveis". ${ }^{168}$

Esse modelo apontado por MacCormick, no entanto, assemelha-se ao processo decisório dos órgãos colegiados no Brasil, no qual, apesar de haver um relator que expõe o voto de maneira mais profunda, os demais juízes manifestam seus pontos de vista discordantes, quando existem no caso.

Thomas Bustamante explica a confusão feita por MacCormick ao afirmar que no civil law não há exposição dos argumentos contrários. É que na França o estilo do julgamento da Corte de Cassação, por exemplo, e o que pode ser atribuído aos tribunais franceses em geral, seria dedutivo, legalista, magisterial e impessoal, porquanto a presunção é a de que a decisão foi tomada por unanimidade. ${ }^{169}$ Fica clara a confusão de MacCormick ao tomar o estilo judicial francês como modelo único do civil law.

E MacCormick defende a exposição de contra-argumentos, pois um juiz discordante poderia ter articulado de modo convincente as próprias razões que precisam ser atacadas para que a justificação da opinião de uma maioria se sustente. ${ }^{170}$ Essas divergências entre votos dos magistrados atuantes no processo, sejam desembargadores ou ministros, segundo MacCormick, fortalecem a necessidade de se construir uma decisão

\footnotetext{
${ }^{167}$ MACCORMICK, Neil. Argumentação Jurídica e Teoria do Direito. São Paulo: Martins Fontes, 2006, p. 10.

${ }^{168}$ Idem, p. 12.

${ }^{169}$ BUSTAMANTE, Thomas da R. de. Teoria do Precedente Judicial: a justificação e a aplicação de regras jurisprudenciais. São Paulo: Noeses, 2012, p. 17.

${ }^{170}$ MACCORMICK, Neil. Argumentação Jurídica e Teoria do Direito. São Paulo: Martins Fontes, 2006, p. 13.
} 
mais bem fundamentada, que não dê espaço para lacunas ou que deixe por analisar aspectos importantes do caso.

Sobre as especificidades do common law na análise das decisões jurídicas, observa MacCormick que uma corte deve convencer-se de que há boas razões suficientes para decidir um caso de uma determinada forma. E por razões suficientes entende-se à luz dos fatos e circunstâncias que as partes tenham levado ao tribunal como material para decidir. ${ }^{171}$ É possível afirmar, portanto, que em alguns casos, apesar da argumentação dedutivista e silogística, subsumindo a norma ao fato, as razões suficientes poderiam ser as fundadas em argumentos consequencialistas.

Outra vantagem para o fortalecimento da argumentação jurídica apontada pelo escocês se refere à forma de escolha dos juízes. Na Inglaterra e na Grã Bretanha, de uma maneira geral não há uma carreira de magistratura, sendo os juízes recrutados entre os advogados que tiveram sucesso no exercício da profissão. ${ }^{172}$ Por esse motivo:

De modo não surpreendente, as razões que fornecem devem muito à argumentação fornecida pelos advogados que se apresentam diante deles. Mesmo quando rejeitam um argumento, eles costumam fazer a cortesia ${ }^{173}$ de indicar aos advogados por que não o aceitaram. ${ }^{174}$

Dessa forma, o cerne da argumentação jurídica desempenhada pelos tribunais seria a necessidade de justificação das decisões com o uso de uma razão jurídica que muda a depender do sistema jurídico no qual está inserido o órgão julgador.

A forma de seleção dos juízes, a história da construção das instituições, enfim, toda a cultura jurídica de cada lugar interfere na construção da argumentação jurídica. Em todas, porém, o que se busca é justificar o porquê daquela decisão e não de outra no caso em questão. Perelman ressalta que a justificação de uma decisão judiciária muda de sentido ao mudar de auditório, ${ }^{175}$ por isso os advogados, ao contrário de médicos ou engenheiros,

\footnotetext{
171 "the most a court should do is satisfy itself that there are sufficiently good reasons for the holding in the present case". "That reasons are sufficient implies sufficiency in the light of the facts and circunstances the parties have adduced to the court as material to the decision they have sought one way or the other. Such a tentative, step-by-step approach to decision-making is certainly very much a characteristic of the development of legal doctrines and principles in the common law". MAcCORMICK, Neil. Rhetoric and the Rule of Law: a theory of legal reasoning. Oxford: Oxford University Press, 2005, p. 93.

${ }^{172}$ MACCORMICK, Neil. Argumentação Jurídica e Teoria do Direito. São Paulo: Martins Fontes, 2006, p. 13.

${ }_{174}$ No Brasil, trata-se de norma constitucional cogente.

${ }^{174}$ MACCORMICK, Neil. Argumentação Jurídica e Teoria do Direito. São Paulo: Martins Fontes, 2006, p. 14.

${ }_{175}$ PERELMAN, Chaïm. Ética e Direito. $2^{a}$ ed. Trad. Maria Ermantina de A. P. Galvão. São Paulo, 2005, p. 565.
} 
que podem exercer sua profissão em qualquer lugar, dependem do conhecimento sobre o seu auditório para que tenham sucesso.

É possível utilizar-se da lógica consequencialista de variadas formas no direito. No caso de MacCormick, parte-se do ponto de vista retórico do uso de argumentação no direito. Essa visão proporciona analisar o direito pela possibilidade de convencimento que os argumentos podem ter.

Dessa forma, os argumentos consequencialistas podem ser construídos sob a forma de entimemas, conhecidos como silogismos incompletos por esconderem parte de suas premissas. Assim, mesmo que não desenvolvidos como silogismos clássicos, como da incidência da norma geral e abstrata sobre o fato jurídico, os argumentos consequencialistas podem convencer e ter um papel central nas decisões do controle de constitucionalidade abstrato de normas orçamentárias.

\subsection{Regra de reconhecimento, o silogismo jurídico e a argumentação dedutiva}

O conceito de regra de reconhecimento foi talhado por Hart. Segundo Billier e Maryoli, seria o seu núcleo do conceito de direito e não constituiria nem uma pressuposição nem uma ficção, mas um fato social. ${ }^{176}$

Hart define as regras de reconhecimento como os critérios últimos usados pelos tribunais para identificar as regras válidas num determinado sistema jurídico ${ }^{177}$ e identifica a regra de reconhecimento com o tema das fontes do direito:

Num moderno sistema jurídico, em que existe uma variedade de "fontes" de direito, a regra de reconhecimento é correspondentemente mais complexa: os critérios para identificar o direito são múltiplos e comumente incluem uma constituição escrita, a aprovação por uma assembleia legislativa e precedentes judiciais. ${ }^{178}$

MacCormick afirma também que a regra de reconhecimento, além de incluir uma regra de validade, pressupõe a existência de "juízes" cujos deveres oficiais são regulamentados pela regra de reconhecimento. Não seriam, portanto, regras aplicáveis pelo

\footnotetext{
${ }^{176}$ BILLIER, Jean-Cassien \& MARYOLI, Aglaé. História da Filosofia do Direito. Barueri: Manole, 2005, p. 408 e 412.

${ }^{177}$ HART, Herbert L. A. O Conceito de Direito. Lisboa: Fundação Calouste Gulbenkian, 2001, p. 161.

${ }^{178}$ Idem, p. 112.
} 
direito, mas o atestado de que para aplicar o direito é preciso conhecer quais regras devem ser aplicadas e qual o critério para se conhecer tais regras.

Segundo MacCormick, a ideia de que há algo por trás da Constituição formal seria um ponto em comum entre as teorias de Kelsen e Hart, ${ }^{179}$ embora a norma fundamental de Kelsen seja diversa da regra de reconhecimento de Hart, por ser, esta sim, um pressuposto de validade.

Assevera que a regra de reconhecimento é um elemento essencial para o positivismo jurídico, e que ao olhar para os elementos em argumentos consequencialistas relativos à competência do Legislativo e ao caráter vinculativo dos precedentes, discute-se em verdade a forma como os juízes chegam a conclusões sobre a aplicação real de regras de reconhecimento por regras válidas da lei dentro do sistema. ${ }^{180}$

A discussão levantada por Hart sobre o reconhecimento das regras que tornam válidas as análises jurídicas remete à discussão sobre os limites das decisões e qual o papel do silogismo e da fundamentação por meio das consequências jurídicas.

Não é fácil defender um silogismo clássico sem entender a subsunção das regras aos fatos. Mesmo na França, onde alguns tribunais adotam o estilo de phrase unique, ${ }^{181}$ a ficção do caráter declaratório nas decisões judiciais é vista como um "anacronismo e como um inconveniente (para não dizer um mal) tanto pela doutrina como pelos juristas práticos de maior projeção nacional e internacional”. ${ }^{182}$

A discussão do silogismo na perspectiva retórica é vista como uma forma de argumentar possível e central no direito, sendo inegável que as decisões jurídicas se utilizam de argumentos silogísticos no momento em que demonstram os dispositivos que incidem sobre o caso tratado.

A discussão silogística é centrada na incidência das normas e na argumentação, daí ser dedutivista. MacCormick diz que, diversamente do senso comum, no sistema do common law esse tipo de argumento tem relevância, mas reconhece que as regras, sozinhas, não podem resolver todos os problemas jurídicos. Para problemas de

\footnotetext{
${ }^{179}$ MACCORMICK, Neil. H. L. A. Hart. Trad. Claudia Santana Martins. Rio de Janeiro: Elsevier, 2010, p. 152.

180 "In looking at consequentialist elements in arguments concerning the powers of legislatures and the binding nature of precedents we are discussing how the judges reach conclusions on the actual application of 'criteria of recognition' for 'valid rules of law' within the system". MACCORMICK, Neil. Legal Reasoning and Legal Theory. Oxford: Clarendon Press, 1978, p.138.

${ }^{181}$ Segundo Thomas Bustamante, um estilo típico dos Tribunais Franceses de "texto único", cuja premissa fundamental era a de que a atividade judicial não passaria de um processo de dedução, da construção de um simples silogismo. BUSTAMANTE, Thomas da R. de. Teoria do Precedente Judicial: a justificação e a aplicação de regras jurisprudenciais. São Paulo: Noeses, 2012, p. 21.

${ }^{182}$ Idem, p. 23.
} 
classificação, de avaliação, de interpretação, de relevância e de provas, pode surgir, e pode ser levado ao litígio, todo tipo de argumentação. ${ }^{183}$ A argumentação a partir de normas somente pode levar até certo ponto:

Pode-se contestar a interpretação da norma como uma fórmula verbal estabelecida; pode-se questionar a correta classificação de fatos ocorrentes como representativos ou não dos fatos operativos estipulados na norma formulada; pode-se ainda, finalmente, discutir se alguma norma chega a ser formulável de modo que justifique a reivindicação de um remédio ou penalidade à luz das alegações do fato. ${ }^{184}$

MacCormick afirma que a fórmula simples, mas muito criticada: " $\mathrm{N}+\mathrm{F}=\mathrm{C}$, onde "Normas + Fatos = Conclusão", é fundamental para entender o fenômeno jurídico. ${ }^{185}$ E que apesar das críticas de que não seria possível ao direito conceder espaço ao raciocínio dedutivo, ou mesmo à lógica, a "noção de uma forma de raciocínio dedutivo é essencial para a argumentação jurídica" ${ }^{186}$ Defende também a positivação dos direitos: "Organizar a ordem jurídica desse modo em torno de um corpus de normas publicadas é a tarefa de qualquer Estado que aspire, ainda que minimamente, a um governo livre”. Essa seria a ideia em si do Estado de Direito. ${ }^{187}$ Pode-se dizer que tal ideia é plenamente adequada aos sistemas romano-germânicos, ainda mais caracterizados pela cultura do código e da norma escrita que os sistemas de origem anglo-saxã.

MacCormick afirma que mesmo que não se possa provar absolutamente ser a argumentação consequencialista essencial na justificação jurídica, ao menos os exemplos expostos por ele no livro "Legal Reasoning and Legal Theory" demonstram que quando há um problema na justificação dedutiva, o recurso citado quase sempre é utilizado em algum grau. $^{188}$

\footnotetext{
183 "Rules cannot solve everything by themselves, for problems of classification, of evaluation, of interpretation, of relevancy, and of proof can arise, and can be raised by parties to trials and to litigation of all sorts". MACCORMICK, Neil. Rhetoric and the Rule of Law: a theory of legal reasoning. Oxford: Oxford University Press, 2005, p. 80.

${ }^{184}$ MACCORMICK, Neil. Argumentação Jurídica e Teoria do Direito. São Paulo: Martins Fontes, 2006, p. XV.

${ }^{185}$ Idem, p. X.

${ }^{186}$ Idem, p. IX.

${ }^{187}$ Idem, p. XII.

188 "Although the mere adduction of examples cannot constitute proof that the consequentialist evaluation of general propositions as possible rulings in law is an essential element of legal justification whenever the two limiting problems of deductive justification arise, the examples at least indicate that any theory must take some account of this sort of evaluation". MACCORMICK, Neil. Legal Reasoning and Legal Theory. Oxford: Clarendon Press, 1978, p.149.
} 
Além do método dedutivo, os argumentos jurídicos também podem ser construídos pelo método indutivo, que parte de casos particulares para induzir uma regra geral aplicável aos demais postos na mesma situação.

No raciocínio anglo-saxão do common law a perspectiva indutiva é muito mais presente, partindo-se da análise do caso concreto para a generalização ou universalização. Já o raciocínio no direito brasileiro parece ser mais centrado na perspectiva dedutiva, fixado na ideia tão debatida da subsunção, mesmo sendo uma ideia por muitos questionada.

O raciocínio indutivo, como visto, é a base de teorias da argumentação jurídica como a tópica, que Viehweg descreve como "técnica do pensamento que está orientada para o problema" e que se oporia ao pensar sistematicamente. ${ }^{189}$ Aliado a isso, é o raciocínio próprio da construção dos precedentes, que pensam a partir da decisão de um caso a razão para se decidir outro caso semelhante, sem necessariamente recorrer à argumentação sobre as normas jurídicas.

Seja o método de construção da decisão indutivo ou dedutivo, o importante para MacCormick é a perspectiva da universalização que a decisão deve trazer consigo, e que será vista detalhadamente no próximo tópico.

\subsection{Universalização das decisões em MacCormick}

A ideia de universalização das decisões judiciais é fundamental para entender a necessidade de se analisar as consequências das decisões jurídicas em Neil MacCormick.

Afirma, nessa linha, que qualquer decisão deve ser universalizada, ${ }^{190}$ pois todos os casos semelhantes devem ter a mesma solução, sob pena de o direito institucionalizar injustiças:

É, portanto, altamente provável que o resultado de certas decisões sobre o Direito seja a produção de comportamentos que ou se conformem ou tirem vantagens das oportunidades oferecidas por elas, ou, de outro

\footnotetext{
189 VIEHWEG, Theodor. Tópica e Jurisprudência: uma contribuição à investigação dos fundamentos jurídico-científicos. Trad. Kelly S. Alflen da Silva. Porto Alegre: Sergio Antonio Fabris Editor, 2008, p. 33.

${ }^{190}$ MACCORMICK, Neil. Retórica e o Estado de Direito. Trad. Conrado Hübner Mendes. Rio de Janeiro: Elsevier, 2008, p. 137.
} 
modo, que ajustem os negócios e as práticas de sorte a se conformarem a elas. ${ }^{191}$

Isso é, quando o Supremo Tribunal Federal decide uma questão, as pessoas tendem a agir conformar a decisão. Se for decidido que um determinado tributo é inconstitucional, as pessoas tendem a não pagar mais tal tributo, ainda que a decisão não tenha efeito erga omnes.

O Judiciário, portanto, mesmo numa lógica dedutiva, só pode conceder um direito a alguém se este direito for extensível a todas as pessoas que se enquadram na mesma situação. Manuel Atienza chama atenção para o fato de que:

O requisito da universalidade, como se sabe, também está implícito na justificação dedutiva. Ele exige que, para justificar uma decisão normativa, se conte pelo menos com uma premissa que seja a expressão de uma norma geral ou de um princípio (a premissa maior do silogismo judicial). ${ }^{192}$

Mas a universalidade não está relacionada à característica de certas normas jurídicas de não serem destinadas a um público específico, de serem gerais. ${ }^{193}$ Ou seja, "uma norma pode ser mais específica que outra, mas ser igualmente universal, pois a universalidade é um requisito de tipo lógico, que não tem relação com a maior ou menor especificidade de outra norma". 194

Nem todas as normas que dão fundamento às sentenças precisam ser gerais. Portanto, é possível que sentenças realizem a subsunção de normas concretas aos fatos jurídicos. No entanto, o requisito da universalidade seria de todas as decisões jurídicas, como requisito da sua própria justificação. Isso porque, em contraste com a deliberação moral, a deliberação jurídica como matéria da Corte, com poucas exceções, é um processo público. E o estabelecimento de razões enquanto públicas necessariamente participa da universalidade, de acordo com MacCormick. ${ }^{195}$

\footnotetext{
${ }^{191}$ Idem, p. 147.

${ }^{192}$ ATIENZA, Manuel. As Razões do Direito: teorias da argumentação jurídica. $3^{\text {a }}$ ed. Trad. Maria Cristina G. Cupertino. São Paulo: Landy Editora, 2006, p. 126.

${ }_{193}$ Para ficar mais claro, de acordo com a classificação de Norberto Bobbio, as normas podem ser gerais ou individuais, abstratas ou concretas. Gerais seriam aquelas ilimitadas em relação aos destinatários, e abstratas aquelas ilimitadas em relação à ação a ser tomada. Dessa forma, poderiam existir normas gerais e abstratas, gerais e concretas, individuais e abstratas, individuais e concretas. BOBBIO, Norberto. Teoria da Norma Jurídica. $2^{a}$ ed. Bauru: Edipro, 2003, p. 180 e 181.

${ }^{194}$ ATIENZA, Manuel. As Razões do Direito: teorias da argumentação jurídica. $3^{\text {a }}$ ed. Trad. Maria Cristina G. Cupertino. São Paulo: Landy Editora, 2006, p. 127.

195 MACCORMICK, Neil. Rhetoric and the Rule of Law: a theory of legal reasoning. Oxford: Oxford University Press, 2005, p. 100.
} 
Justificar razões, portanto, exigiria que essas razões fossem subsumidas pela universalização, mesmo que a universalização seja questionável. ${ }^{196}$ Tem-se como exemplo o argumento desenvolvido pelo Ministro Marco Aurélio Mello no Acórdão da ADI 2.9258:

Todos estamos de acordo com a supremacia da Carta da República. Agora, se existe tanta dúvida, a ponto de se ajuizar a ação direta de inconstitucionalidade, evidentemente, precisamos partir, a fim de evitar controvérsias futuras, para a interpretação conforme e proclamar que não pode haver a utilização, como crédito suplementar, dessa rubrica que tem destinação peremptória, categórica, em texto exaustivo na Carta da República. (Grifo nosso)

Gilmar Mendes, nesse mesmo Acórdão da ADI 2.925-8, ressalta a necessidade de universalização defendida por MacCormick e afirma que:

Mas estamos a ver que o tema é assaz complexo, é um daqueles casos em que, talvez, devêssemos nos valer da fórmula da Lei $n^{\circ} 9.868$ e realizar algo como ou uma audiência pública ou até a designação de um debate entre "experts". Acho que era um típico caso para que pudéssemos analisar a repercussão não só nesse caso, mas em outros. (Grifo nosso)

Afirma MacCormick que mesmo em decisões judiciais em casos concretos, especialmente em tribunais de apelação, e em qualquer medida, em um dado sistema jurídico há uma prática de seguir o precedente ou até mesmo uma regra exigindo isso. ${ }^{197}$ Talvez por isso a discussão sobre a universalização seja mais presente em países onde os precedentes são vinculantes, sobretudo dos tribunais superiores.

Decisões não são justificáveis apenas pelos efeitos que causam nas partes, mas em termos de uma proposição legal aceitável que cubra o caso em análise e seja passível de aplicação em outros casos parecidos ou semelhantes. ${ }^{198}$ A decisão universalizada torna-se

\footnotetext{
196 "To be justifying reasons they have to be subsumable under a relevant principle of action universally stated, even if the universal is acknowledged to be defeasible". Idem, p. 99.

197 "What is distinctive about judicial decisions in actual cases is that, especially in appellate courts, and to whatever extent in a given legal system there is a practice of following precedent or even a rule requiring this, the universalized decision does become a kind of rule for everyone else". Idem, p. 103.

198 "Decisions are not justified in terms of their direct immediate affects on the parties alone (that is when hard cases make bad law), but in terms of an acceptable proposition of law that covers the present case and is therefore available for other like cases". Idem, Ibdem.
} 
um tipo de regra para todos. ${ }^{199}$ Ao menos o juiz ao decidir deve ter em mente esse "efeito" de sua decisão.

Devido à natureza institucional e à configuração da prática de julgamento, e porque tal prática está devidamente regulada, ao menos pelo princípio da justiça formal, a justificação de decisões judiciais pressupõe o uso de razões universalizáveis. ${ }^{200}$

MacCormick ressalta um cuidado a se tomar, ao afirmar que qualquer universalização de uma razão em um caso particular tem de ser aceita com certa cautela, porque as circunstâncias diferentes podem sugerir exceções e qualificações que não são desencadeadas nas circunstâncias do caso em análise. ${ }^{201} \mathrm{O}$ fato de que no momento da construção da sentença o magistrado deve ter em mente a universalização de sua decisão não quer dizer que ela será aplicável a qualquer outro caso que venha a ocorrer; é prudente, mesmo em termos de segurança jurídica, decidir casos iguais de forma semelhante.

Nesse sentido, a universalização proposta não pressupõe sejam os casos absolutamente iguais, mas que cada caso decidido tenha em conta que há outros casos cuja dessemelhança não admitiria um tratamento diferente, porque as características que os distinguem não são suficientes para tratá-los desigualmente. A ideia de universalização, pois, se aproxima da noção de precedente. Desse modo, a universalidade seria pensar cada decisão como o estabelecimento de um precedente sobre o caso.

E mais do que isso, a ideia de universalização está mais relacionada a que tipo de razão deve ser posta pelo juiz no momento da construção da sua justificação, do que a uma necessidade de que o juiz aplique decisões anteriores ao caso. Isso porque, como afirma MacCormick, uma decisão deve ser tomada pensando que pode servir de exemplo, ou pode ter implicações em como as pessoas podem se comportar no futuro, ${ }^{202}$ o que serve de fundamento à análise consequencialista feita pelo autor:

Decidir um caso e justificar a decisão exige que essa decisão possa ser universalizada, ao menos implicitamente, e que possa ser comparada

\footnotetext{
199 "What is distinctive about judicial decisions in actual cases is that, especially in appellate courts, and to whatever extent in a given legal system there is a practice of following precedent or even a rule requiring this, the universalized decision does become a kind of rule for everyone else". Idem, Ibdem.

200 "Because of the institutional nature and setting of the practice of adjudication and because such a practice is properly governed at least by the principle of formal justice, to treat like cases alike, justified judicial decisions presuppose universalizable reasons or rulings in law that 'cover' the particular decision justified. And only well-justified rulings can in turn justify decisions". Idem, p. 104.

201 "It is certainly true that any universalization from a particular reason in a particular case has to be accepted with a certain caution, because different circumstances may suggest exceptions and qualifications that are not triggered in the circumstances of the case under consideration". Idem, p. 90.

202 "A decision that be taken as an example could have implications for the kinds of ways people might behave in future". Idem, p. 83.
} 
qualitativamente com os méritos de uma outra possível solução universal (ainda que pouco definida) que lhe seja rival. ${ }^{203}$

O juiz, portanto, ao tomar uma decisão jurídica deve supor que se todos os outros tomarem a mesma decisão diante de pressupostos fáticos semelhantes, a consequência advinda do resultado proposto seria exequível e benéfica para a sociedade.

A questão não consiste em saber se qualquer pessoa irá de fato agir com base na regra contemplada, quer seja ela uma regra de permissão ou de obrigação. Trata-se de saber se alguém poderia concordar sinceramente com essa regra se ela fosse uma regra observada por todos. ${ }^{204}$

Luis Fernando Schuartz adere à proposição de MacCormick e afirma que:

$\mathrm{O}$ decisor tem de ser capaz de perceber sua decisão enquanto precedente para decisões futuras. $\mathrm{O}$ juiz deve confrontar-se com o futuro como cenário de vigência de um conjunto de decisões relativo a uma classe de atividades e situações, decisões cujas consequências agregadas ele não poderá simplesmente ignorar. ${ }^{205}$

Fundada a opinião de MacCormick que justificar uma decisão jurídica requer universalização, surge a questão de como a proposição universalizada é em si justificada. A resposta dada é que a justificação se dá por meio das consequências, desde que o termo seja utilizado em um sentido especial proposto pelo autor.

Ela está ligada à razão prática utilizada pelo autor. Segundo Thomas Bustamante, um dos caminhos teóricos para a racionalidade prática, de concepção kantiana, se encontraria na ideia de universalizabilidade ${ }^{206}$ de que os atos devem ser praticados apenas quando possam ser defendidos universalmente. O próprio Kant afirma que "ser consequente é a maior obrigação de um filósofo e é, contudo, o que mais raramente se encontra". ${ }^{207}$ Não há, como será visto, uma contradição entre a ideia de universalizabilidade e a razão consequencialista para decidir.

\footnotetext{
${ }^{203}$ MACCORMICK, Neil. Retórica e o Estado de Direito. Trad. Conrado Hübner Mendes. Rio de Janeiro: Elsevier, 2008, p. 137.

${ }^{204}$ Idem, p. 138.

205 SCHUARTZ, Luis Fernando. Consequencialismo jurídico, racionalidade decisória e malandragem, in MACEDO JR, Ronaldo Porto \& BARBIERI, Catarina H. Cortada. Direito e Interpretação: racionalidades e instituições. São Paulo: Saraiva, 2011, p. 398.

${ }^{206}$ BUSTAMANTE, Thomas da R. de. Teoria do Precedente Judicial: a justificação e a aplicação de regras jurisprudenciais. São Paulo: Noeses, 2012, p. 191.

${ }^{207}$ KANT, Immanuel. Crítica da Razão Prática. Trad. Valerio Rohden. São Paulo: Martins Fontes, 2011 , p. 41.
} 


\subsection{Julgando com o uso de consequências}

MacCormick aponta dois extremos, para ele insustentáveis, para o uso de consequências em decisões judiciais. Num extremo, a única justificação de uma decisão seria em termos de consequências, considerando o maior benefício em rede, tomando em conjunto todas as consequências e julgando pelo critério mais adequado de benefício e detrimento. $^{208}$ Essa visão extrema excluiria, segundo MacCormick, a possibilidade de alguma justificação racional de qualquer decisão, uma vez que o futuro é incerto. ${ }^{209}$

No outro extremo, a natureza e a qualidade da decisão, independentemente de qualquer consequência mesmo que próxima, seriam suficientes em termos de justificação e correção (rightness). ${ }^{210}$ Ignorar-se-iam duas coisas: a natureza e a qualidade das decisões e atos, constituídos pelas consequências que o responsável pela decisão previu ou deseja para eles; e, o que MacCormick considera mais sério, ignora que tanto a prudência quanto a responsabilidade para com o semelhante requerem que se pense seriamente sobre os resultados previsíveis de seus atos e decisões, antes de finalmente agir ou decidir, tanto mais quanto mais importante for o ato ou decisão a ser realizado. ${ }^{211}$ Ele afirma que a responsabilidade em geral é atribuída às pessoas para as consequências previstas e previsíveis e resultados de suas ações, e os juízes não seriam exceção.

MacCormick propõe, portanto, uma visão intermediária, segundo a qual alguns tipos de razões sobre consequências são de importância decisiva na justificação de decisões jurídicas. ${ }^{212}$ Em todos os casos, lida-se com problemas legais, não com questões morais ou políticas tomadas cruamente. Portanto, a resposta sempre tem de ser enquadrada em termos da lei, através da interpretação de estatutos ou de precedentes, ou de princípios jurídicos que desenvolveram a reflexão sobre o direito como uma ordem normativa praticamente coerente. $^{213}$

\footnotetext{
${ }^{208}$ MACCORMICK, Neil. Rhetoric and the Rule of Law: a theory of legal reasoning. Oxford: Oxford University Press, 2005, p. 101.

${ }^{209}$ Idem, p. 102.

${ }^{210}$ Idem, p. 101.

211 "it ignores the extent to which both prudence and responsibility to one's fellows require that one give serious thought to the foreseeable outcomes of one's acts and decisions before finally acting or deciding, the more so the more momentous the act or decision in view". Idem, p. 102.

${ }^{212}$ Idem, Ibdem.

213 "In all cases, we are dealing with legal problems, not with moral or political issues taken in the raw. So the answer always has to be capable of being framed in terms of the law, through interpretation of statutes or of precedents, or of legal principles developed though reflection on law as a practically coherent normative order". Idem, Ibdem.
} 
Portanto, analisar o direito sob a teoria de Neil MacCormick nada tem a ver, ou ao menos não tem a ver exclusivamente, com a avaliação de consequências não jurídicas. As consequências devem, muito pelo contrário, ser analisadas em relação ao direito, e nunca afastadas dele.

O que é difícil na análise das consequências é a extensão que os juízes devem considerar, e as bases em que deve avaliá-las. As consequências sociais, especialmente as consequências em longo prazo, da adoção de uma regra jurídica e não de outra são notoriamente difíceis de calcular. ${ }^{214}$

Entre outras críticas que podem ser apontadas ao consequencialismo está a de que as leis podem produzir, em seu processo normal de aplicação, consequências inesperadas, e juízes e advogados não seriam capacitados para esse tipo de tarefa ou análise, mesmo em comparação ao corpo do Executivo e do Legislativo. ${ }^{215}$ Até mesmo porque o cumprimento das normas pelas pessoas depende de uma série de fatores que não cabe aos juízes especular, uma vez que tais profissionais não possuem aparato técnico para dispor desses elementos em comparação ao Poder Legislativo e, principalmente, ao Executivo. $^{216}$

Assim, o que MacCormick chama de razão jurídica consequencialista não é tanto a estimativa da probabilidade de mudanças comportamentais, e sim a possível conduta e seu estatuto normativo determinado à luz da decisão analisada. ${ }^{217} \mathrm{O}$ juiz, pois, não tenta prever quais as consequências e comportamentos das pessoas em razão de sua decisão, mas sim qual a "regra universal" que foi posta por ele em sua decisão. Mesmo porque não podemos especular sobre todas as coisas que vão ou poderão, eventualmente, acontecer se as pessoas reagem de alguma forma ou de outra a uma nova sentença jurídica. Mas, se as pessoas devem agir conforme a lei, quando elas agem como o tribunal decide, os juízes devem esperar essa adequação comportamental e considerar isto em suas decisões. $^{218}$

\footnotetext{
214 "What is difficult about this concerns the extensiveness of the consequences that judges should consider, and the basis on which they should evaluate them. The social consequences, especially the long-term social consequences, of adopting one legal rule rather than another are notoriously difficult to calculate". MACCORMICK, Neil. Rhetoric and the Rule of Law: a theory of legal reasoning. Oxford: Oxford University Press, 2005, p. 103.

${ }^{215}$ Idem, p. 103 e 104.

${ }^{216}$ MACCORMICK, Neil. Retórica e o Estado de Direito. Trad. Conrado Hübner Mendes. Rio de Janeiro: Elsevier, 2008, p. 138.

${ }^{217}$ MACCORMICK, Neil. Rhetoric and the Rule of Law: a theory of legal reasoning. Oxford: Oxford University Press, 2005, p. 110.

${ }^{218}$ Idem, p. 111.
} 
Tárek Moussallem, sobre o uso de consequências no direito, distingue duas espécies: consequencialismo externo, quando o argumento consequencialista não tiver sido previsto em hipótese normativa, e, portanto, não poderia ser levado em consideração "quando da prolação do ato de fala". Nesse caso o autor menciona como exemplo a chamada "análise econômica do direito"; e o consequencialismo interno, este válido para o direito, quando analisada a consequência prevista em hipótese normativa. E afirma que: "A consequência de toda norma jurídica (e qualquer decisão) deve ser mensurada internamente ao direito positivo e não pelo prisma econômico ou social". ${ }^{219}$

Assim, na opinião de Tárek Moussallem, que se baseia na teoria de Neil MacCormick, argumentos extrajurídicos, ou o que ele chamou de consequencialismo externo, não poderiam ser aceitos pelo Supremo Tribunal Federal, que estaria adstrito aos "fatos jurídicos constitucionais", "sob pena de inversão total dos valores estampados na Constituição Federal". 220

De forma simples, se o Supremo Tribunal Federal decide, por exemplo, que o Executivo não pode alterar a proposta enviada pelo Judiciário no momento de formulação da lei orçamentária no Estado de Alagoas, é previsível que os demais Estados da Federação passem a entender que não é dada a eles a oportunidade de alterar também as suas propostas. Essa análise consequencialista não é complexa nem exige um conhecimento matemático dos juízes. Mesmo que os efeitos da decisão do exemplo sejam inter partes, é razoável entender que as administrações públicas do país passarão a agir daquela forma.

Atienza faz ainda uma distinção à luz da teoria de MacCormick sobre o resultado e as consequências de uma ação:

O resultado da ação do juiz ao decidir um caso consiste em produzir uma norma válida; o resultado, poderíamos dizer, faz parte do próprio conceito de ação, embora uma mesma ação possa ser descrita como produzindo resultados diferentes. As consequências são o estado das coisas, posterior ao resultado (e relacionado com ele). ${ }^{221}$

Atienza expõe também a diferença entre as consequências ligadas casualmente ao resultado, e as remotas, que não estão ligadas casualmente à ação. Expõe as dificuldades

219 MOUSSALLEM, Tárek Moysés. Argumentação Consequencialista na Jurisprudência do Supremo Tribunal Federal, in SOUZA, Priscila de. Sistema Tributário Brasileiro e Crise Atual. VI Congresso Nacional de Estudos Tributários. São Paulo: Noeses, 2009, p. 974 e 975.

${ }^{220}$ Nesse sentido, a proposta de Moussalem parece ser ainda mais restrita que a de MacCormick, por pressupor que o juiz deve se ater a fatos jurídicos constitucionais, que pressupõem a incidência de uma norma sobre o caso. Idem, p. 976 e 978.

${ }^{221}$ ATIENZA, Manuel. As Razões do Direito: teorias da argumentação jurídica. $3^{\text {a }}$ ed. Trad. Maria Cristina G. Cupertino. São Paulo: Landy Editora, 2006, p. 133. 
da avaliação das consequências e discorda de MacCormick quanto à importância do uso de consequências nas decisões:

\begin{abstract}
Além de ser algo extraordinariamente difícil, o estabelecimento de quais sejam as consequências de uma decisão - nos dois sentidos anteriormente indicados - não costuma ter um papel importante na justificação das decisões, a não ser em algumas áreas do Direito (por exemplo, o Direito Fiscal), nas quais é frequente levar-se em conta as decisões judiciais - ou administrativas - para atuar de uma forma ou de outra no futuro. O que importa são, antes, as consequências no sentido de implicações lógicas. Mais que a previsão de qual conduta a norma provavelmente irá induzir ou desestimular, o que interessa é responder à pergunta de que tipo de conduta autorizaria ou proibiria a norma estabelecida na decisão; em outras palavras, os argumentos consequencialistas são, em geral, hipotéticos, mas não probabilistas. ${ }^{222}$
\end{abstract}

MacCormick afirma que para entender as consequências como relevantes na justificação de decisões é preciso olhar além das consequências casuais e particulares ao caso, e o ato em si de justificação das decisões irá provar que tipo de consequências importará. $^{223}$

MacCormick aduz que, por serem as leis concebidas de uma forma intencionalmente racional, no caso de qualquer decisão em uma área não regida por uma regra expressa obrigatória, ou quando tal regra é ambígua ou incompleta, deve-se continuar testando as decisões propostas à luz de suas consequências. Mas porque a justificativa mostra a razão de tal decisão ir por um caminho e não por outro, as consequências relevantes são as da sentença envolvida na decisão, e não apenas os efeitos específicos da decisão sobre as partes individuais. ${ }^{224}$ As razões para decidir, portanto, são sempre universais; os efeitos podem ou não ser.

MacCormick afirma que na falta de precedentes vinculantes sobre o caso há uma liberdade maior do julgador para decidir utilizando argumentos consequencialistas. ${ }^{225}$

\footnotetext{
${ }^{222}$ ATIENZA, Manuel. As Razões do Direito: teorias da argumentação jurídica. $3^{\mathbf{a}}$ ed. Trad. Maria Cristina G. Cupertino. São Paulo: Landy Editora, 2006, p. 134.

${ }^{223}$ MACCORMICK, Neil. Rhetoric and the Rule of Law: a theory of legal reasoning. Oxford: Oxford University Press, 2005, p. 104.

224 "Given that laws are conceived of in that rational purposive way, it does indeed seem essential that the justification of any decision in an area not governed by an express mandatory rule, or when such rule is ambiguous or incomplete, should proceed by testing the decisions proposed in the light of their consequences. But because the justification proceeds by way of showing why such a decision ought to go one way rather than the other, the relevant consequences are those of the generic ruling involved in deciding one way or the other, not just the specific effects of the specific decision on the individual parties". MACCORMICK, Neil. Legal Reasoning and Legal Theory. Oxford: Clarendon Press, 1978, p.149 e 150.

225 "It is admitted that there is no precedent for the present action by a servant against a master. We are therefore at liberty to decide the question upon general principles, and in so doing we are at liberty to look at the consequences of a decision one way or the other". Idem, p. 136.
} 
A falta de regras ou princípios que induzam um comportamento mais definido, portanto, deixaria uma liberdade maior para o uso de argumentos fundados em consequências.

Não parece, entretanto, que os argumentos consequencialistas possam ser utilizados apenas em caso de lacunas. Toda decisão, em maior ou menor grau, deve apreciar suas consequências jurídicas. Apenas há uma liberdade maior para compor a justificação da decisão com argumentos consequencialistas quando a argumentação dedutiva não for substancial.

Manuel Atienza entende que, na teoria de MacCormick, a escolha entre interpretações finais ocorre, ou ao menos pode ocorrer, de acordo com argumentos consequencialistas. $^{226}$ Por esse caminho, o argumento consequencialista seria utilizado caso o intérprete já possua vários sentidos possíveis da norma.

Prakash chega a afirmar que usar o consequencialismo como uma ferramenta de construção de significado seria semelhante à utilização de um martelo sobre um parafuso. ${ }^{227}$ Segundo essa visão, a análise consequencialista não faria parte do processo interpretativo, mas seria apenas um critério de escolha entre as várias interpretações possíveis, argumento com o qual não podemos concordar.

A análise das consequências faz parte do processo interpretativo, assim, pensar de modo consequencialista altera a percepção que se tem sobre o processo dedutivo das normas. $\mathrm{O}$ caráter argumentativo do direito, especialmente sob a perspectiva retórica, faz crer que a argumentação dedutiva não é sempre preponderante, e o que pode convencer o magistrado e influenciar no seu processo cognitivo de interpretação pode variar de acordo com a matéria e a forma de exposição dos argumentos pelas partes, mesmo que sob a forma de entimemas, ou raciocínios não completos no sentido lógico.

Não há como separar o processo interpretativo e justificador da norma que incide sobre o caso e o uso de argumentos consequencialistas. Mesmo porque argumentos consequencialistas podem levar o magistrado a buscar outras normas, princípios ou regras, que incidam sobre o caso de forma a resultar nas melhores consequências. ${ }^{228}$ Não há garantia de que os três requisitos de MacCormick para uma boa fundamentação -

${ }^{226}$ ATIENZA, Manuel. As Razões do Direito: teorias da argumentação jurídica. $3^{a}$ ed. Trad. Maria Cristina G. Cupertino. São Paulo: Landy Editora, 2006, p. 151.

227 "To use consequentialism as a tool to discern meaning would be akin to using a hammer on a screw". PRAKASH, Saikrishna. Radicals in Tweed Jackets: why extreme left-wing Law professors are wrong for America. Columbia Law Review. Vol. 106, N. 8, 2006. Disponível em: <http://www.jstor.org/stable/40041696>. Acesso em 1\%/2/2012, p. 2.225 .

${ }^{228}$ Aqui existe uma premissa de que não há apenas uma incidência correta sobre cada caso, mas uma multiplicidade de incidências que podem ser construídas pelo juiz. 
coerência, consistência e consequências - sejam pensados em ordem cronológica, e não desenvolvidos aleatoriamente a depender das circunstâncias de cada caso.

Uma dificuldade adicional seria a da avaliação em si. Mesmo que se tenham estabelecido prováveis consequências para uma decisão em vez de outras, como avaliar isso? Existe uma única métrica de avaliação disponível, tal como proposto pelos defensores da "análise econômica do direito", ou quem faz isso só apresenta uma técnica arbitrária para submeter valores incomensuráveis em uma escala de medida? ${ }^{229}$

Nesse caso, as diversas teorias jurídicas que estudam e propõem o consequencialismo também possuem resultados diversos. Cada área do direito na perspectiva da retórica possui argumentos consequencialistas que vão convencer mais ou menos a depender do auditório e dos demais fatores retóricos.

A experiência comum sugere, segundo MacCormick, que o maior peso deve ser dado aos resultados na forma de prováveis mudanças de comportamento em relação a decisões novas, quando estas são realmente prováveis. Isso significa que, nessas áreas, é particularmente provável que as pessoas fundamentem suas ações na lei como está previsto por parte dos tribunais. ${ }^{230}$ Uma dessas áreas, segundo MacCormick, seria o Direito Tributário, em que as empresas, os cidadãos de maneira geral e o próprio Estado tenderiam a se conformar às decisões e seguir os precedentes de forma mais intensa que nas demais áreas.

No direito público em geral, se é que essa classificação subsiste, as decisões judiciais tendem a ser reproduzidas pelos cidadãos que estejam em situações semelhantes. Quanto mais especializado o grupo de pessoas que se submete às regras, mais provável que passem a agir conforme as decisões.

Tendo como pressuposto a necessidade de prolatar decisões que são universalizáveis, decidir pensando nas consequências envolve em boa parte pensar como as pessoas agirão diante daquela decisão.

\footnotetext{
229 "A further difficulty concerns evaluation itself. Even if you have established likely consequences of one decision rather than another, how do you evaluate these? Is there a single metric of evaluation available, such as that proposed by supporters of the 'economic analysis of law', or does this amount only to an arbitrary technique for subjecting incommensurable values to a single scale of measurement?". MACCORMICK, Neil. Rhetoric and the Rule of Law: a theory of legal reasoning. Oxford: Oxford University Press, 2005, p. 104.

230 "Common experience suggests that the greatest weight should be given to outcomes in the way of probable behavioural changes in respect to novel rulings when these are really likely. That means, in those areas where it is particularly likely that people will explicitly ground their actions in the law as it is laid down (inter alia) by courts". Idem, p. 110.
} 
O raciocínio é simples. Toda vez que o Supremo Tribunal Federal julga a perda do objeto de uma ação que aprecia a constitucionalidade de uma lei orçamentária porque esta já esgotou o seu período de vigência, o Tribunal deve ter em mente que está condicionando a validade das leis orçamentárias à sua vigência e estimulando a formulação de leis orçamentárias inconstitucionais, pois o seu período de vigência é sempre curto. ${ }^{231}$ Dessa forma, quando o STF julga leis orçamentárias, talvez fosse prudente julgar sua constitucionalidade independentemente de terminado o seu período de vigência, tamanhos os efeitos danosos que essas decisões vêm provocando. Decidir assim, concordando-se ou não com a decisão, seria decidir fundado em argumentos de ordem consequencialista.

Percebe-se que nesse caso a decisão poderia ser fundamentada em princípios e regras constitucionais, como supremacia da Constituição, até mesmo na norma da democracia, tendo em vista que o procedimento democraticamente eleito para a definição de receitas e despesas é a lei orçamentária. Mas o argumento foi construído com premissas fixadas nas consequências. Essa motivação não tem fundamentos extrajurídicos e tende a ser aceita pela comunidade jurídica sem grandes percalços.

Em termos gerais, e especialmente na vertente da necessidade de universalização, a argumentação consequencialista pode ser fundamentada juridicamente nos princípios da Justiça e da Igualdade, pela necessidade de tratamento de casos semelhantes de forma semelhante, de maneira que a justificação dada ao caso presente possa ser utilizada no futuro em casos similares. ${ }^{232}$ Nesse sentido, Luis Fernando Schuartz afirma que o mais racional e juridicamente obrigatório para a aceitação de consequências jurídicas é o princípio da igualdade e a necessidade de consistência entre as decisões. ${ }^{233}$

MacCormick aponta outros argumentos comumente relacionados à análise consequencialista, como o senso comum, justiça, adequação aos princípios jurídicos e de políticas públicas, ${ }^{234}$ e relaciona também a importância de argumentos consequencialistas em tempos de guerra, já que o tema da segurança nacional normalmente é colocado em raciocínio argumentativo consequencialista. ${ }^{235}$

\footnotetext{
${ }^{231}$ Sobre o problema da falta de controle nos orçamentos em virtude do seu curto período de vigência, ver: CHRISTOPOULOS, Basile G. C. Despesa Pública: estrutura, função e controle judicial. Maceió: Edufal, 2011.

${ }_{232}$ MACCORMICK, Neil. Legal Reasoning and Legal Theory. Oxford: Clarendon Press, 1978, p.150.

${ }^{233}$ SCHUARTZ, Luis Fernando. Consequencialismo jurídico, racionalidade decisória e malandragem, in MACEDO JR, Ronaldo Porto \& BARBIERI, Catarina H. Cortada. Direito e Interpretação: racionalidades e instituições. São Paulo: Saraiva, 2011, p. 398.

${ }^{234}$ MACCORMICK, Neil. Legal Reasoning and Legal Theory. Oxford: Clarendon Press, 1978, p.151.

${ }^{235}$ Idem, p.134.
} 
Além desses, pode-se apontar o argumento baseado na ideia de segurança jurídica. As mudanças constitucionais feitas nos últimos anos no controle de constitucionalidade brasileiro, especificamente no caso da modulação de efeitos, têm como fundamento a segurança jurídica. Nesse sentido, como será visto à frente, modulam-se os efeitos para evitar uma quebra da segurança jurídica, antevendo as consequências que podem causar instabilidade no sistema jurídico.

Nos três primeiros capítulos buscou-se apresentar o consequencialismo como teoria capaz de explicar a fundamentação jurídica das decisões judiciais. Dessa forma, o consequencialismo que será utilizado para fundamentar as análises das decisões prolatadas pelo Supremo Tribunal Federal na segunda parte da tese será essencialmente jurídico.

Assim, embora a defesa de um argumento consequencialista possa ter fundamento moral, no sentido de ser "boa" a decisão geradora das melhores consequências possíveis, a restrição de que tais consequências devem ser jurídicas aumenta não apenas a possibilidade de que esses argumentos sejam aceitos pela comunidade jurídica, tendo em vista que o auditório é propenso a aceitar esse tipo de restrição, sendo também a melhor forma de razão a ser desenvolvida.

Há ainda uma última diferença fundamental entre o consequencialismo de MacCormick e o defendido pelo pragmatismo e pela análise econômica do direito. O pragmatismo não está restrito à análise das consequências no contexto das razões justificadoras, mas também atua fortemente nas razões explicativas.

Isto é, o pragmatismo e, especialmente, a análise econômica do direito, está preocupada com as razões que levaram o juiz a decidir de determinada forma. O juiz é visto como o ser racional que decide de determinada forma porque certas condições foram a ele impostas e etc.

No caso do consequencialismo de MacCormick, as consequências que importam são aquelas presentes nos processos e nas razões apresentadas pelo juiz na sentença ou acórdão, o que se ajusta melhor ao proposto nesta tese.

\subsection{O argumento consequencialista jurídico}

Neste tópico serão feitos eventuais ajustes à teoria do escocês Neil MacCormick, sintetizando-se as principais ideias da primeira parte do trabalho, para 
definir o marco teórico e o conceito de consequencialismo jurídico que será defendido ao longo da tese.

Fundamentadas as ideias principais sobre o consequencialismo e também sobre a argumentação jurídica, cabe agora unir os dois temas, sustentando a possibilidade de construção de argumentos - no direito e fora dele - que utilizem a lógica fundada nas consequências.

É possível observar o fenômeno jurídico por diversas lentes. A argumentação jurídica é uma delas, extremamente qualificada para observar decisões judiciais. E, dentro das teorias da argumentação jurídica, a retórica fornece os elementos mais adequados para testar o que é convincente em cada decisão, auxiliando a descobrir a teia que constitui a argumentação de cada decisão judicial.

Além disso, a análise retórica é extremamente adequada à busca de precedentes que não se limitam à subsunção clássica da norma sobre o fato, mas são extraídos em cada decisão que convence o auditório de estar ali o direito e a orientação que todos devem seguir.

O consequencialismo foi visto em diversas vertentes, desde o aspecto moral até as teorias que influenciaram o consequencialismo jurídico, como o utilitarismo, o pragmatismo e a análise econômica do direito, com foco especial em Posner. Para este, a visão pragmatista da análise econômica do direito, tendo o consequencialismo como critério auxiliar ao deontológico, serviria para apontar consequências absurdas ou catastróficas. $^{236}$

Por fim, o consequencialismo jurídico foi visto da perspectiva de Neil MacCormick, referência para esta tese por vislumbrar uma proposta ao mesmo tempo adequada ao positivismo jurídico tradicional e que não despreza as consequências trazidas inevitavelmente por qualquer decisão.

O referencial no jurista escocês permite distinguir consistentemente argumentos consequencialistas em jurídicos e extrajurídicos; intrajurídicos e extrajurídicos; internos ou externos.

O critério de distinção é o tipo de consequência alegada no argumento. Se a consequência alegada é uma consequência prevista no direito em alguma norma, há o argumento consequencialista jurídico, intrajurídico ou interno; se a consequência prevista no argumento é alheia ao direito, de natureza econômica, sociológica ou de qualquer outra

${ }^{236}$ POSNER, Richard. Law, Pragmatism, and Democracy. Cambridge/London: Harvard University Press, 2003, p. 82. 
matéria, ter-se-á um argumento consequencialista extrajurídico ou externo. Segundo Luis Fernando Schuartz:

Decisões judiciais têm consequências extrajurídicas e intrajurídicas. Essas são as consequências que as decisões produzem em termos de restrições ou extensões do espaço juridicamente aceitável para decisões futuras. Consequências intrajurídicas ocorrem a reboque das implicações materiais que se ligam ao conteúdo semântico das decisões e dos argumentos firmados como seus fundamentos, $i$. $e$., na forma de conclusões de inferências materialmente válidas que incluem as decisões, junto com os argumentos em questão, como suas premissas. ${ }^{237}$

À proposta de MacCormick adere a ideia de que argumentos consequencialistas jurídicos estão ligados à noção de universalidade, pois as consequências jurídicas que podem ser previstas pelo juiz são aquelas pertinentes ao status jurídico do qual a matéria passará a dispor, servindo de "regra" para as decisões tomadas no futuro pelas pessoas que buscam cumprir o direito.

Uma preocupação menor com a probabilidade de mudança comportamental, visto que seria inviável ao juiz considerar boa parte dessa análise em qualquer questão, e mais um argumento sobre que mensagem jurídica aquela decisão deixa para o sistema, estabelecendo, quando for o caso, por exemplo, um precedente para a questão.

Este trabalho não busca produzir uma teoria "pura" do consequencialismo jurídico, embora a classificação de um argumento como consequencialista extrajurídico ou externo exponha de alguma forma uma crítica a uma atuação judicial. Mesmo porque argumentos consequencialistas dessa natureza podem ser extremamente convincentes e persuasivos, e não devem ser descartados na análise retórica. Argumentos que tentem especular as repercussões econômicas de uma decisão, como desemprego, por exemplo, podem ser essenciais para entender a justificação de uma decisão, ainda que fundados em algum artigo constitucional que protege o pleno emprego.

Esse tipo de argumentação é comum e relevante para o direito. No caso do direito tributário há, por exemplo, o argumento do "rombo nos cofres públicos" em ações que julgam tributos inconstitucionais e preveem a repetição do indébito. Nesses casos, o argumento consequencialista externo, como o de dificuldades na atividade financeira do Estado, pode e será expresso em linguagem mais próxima ao direito, utilizando-se muitas das vezes de princípios como a segurança jurídica. É possível levantar no caso um

${ }^{237}$ SCHUARTZ, Luis Fernando. Consequencialismo jurídico, racionalidade decisória e malandragem, in MACEDO JR, Ronaldo Porto \& BARBIERI, Catarina H. Cortada. Direito e Interpretação: racionalidades e instituições. São Paulo: Saraiva, 2011, p. 397. 
argumento consequencialista jurídico, nos termos propostos por MacCormick, que seria o relacionado à mensagem jurídica de que é possível a cobrança de tributos inconstitucionais, desde que a arrecadação seja suficientemente relevante para o Estado ao ponto de não poder ser repetida. Nesse caso, não se pode descartar como convincente o primeiro argumento.

$\mathrm{O}$ argumento consequencialista jurídico, interno ou intrajurídico, portanto, prevê consequências boas ou ruins dentro do contexto normativo. Utilizando um argumento exemplificativo, tem-se um argumento consequencialista jurídico quando uma decisão afirma que a interpretação $x$ sobre uma determinada norma poderia levar a um patamar jurídico de restrição ao acesso à justiça pela população. Há nesse exemplo uma formulação baseada nas consequências da decisão, mas consequências que são tuteladas pelo direito, como a norma que garante o acesso à justiça.

Outro exemplo poderia ser dado no mesmo sentido quando se argumenta que a decisão favorável para Constantino servirá de exemplo para outros casos, consistindo em precedente para que outros possam tutelar o mesmo benefício. Verifica-se, portanto, um argumento consequencialista jurídico, pois sua formulação envolve uma consequência prevista no direito, que é a igualdade, entre outras normas.

No caso dos argumentos consequencialistas extrajurídicos, pode-se dar como exemplo a repercussão econômica de uma decisão que declara inconstitucional um determinado tributo sobre a exportação. Poderia o juiz ao decidir o caso argumentar que se declarado inconstitucional o tributo, a economia do país viria a sofrer sérios danos, afetando o mercado interno e os preços praticados.

Outro exemplo de argumento consequencialista extrajurídico seria o de uma decisão sobre a constitucionalidade de novos direitos estendidos às empregadas domésticas fundar sua inconstitucionalidade no risco iminente de desemprego para essa categoria.

Gilmar Mendes amplia e especializa a discussão consequencialista para o debate sobre o uso de fatos em tribunais superiores, como o STF, que a princípio não podem reexaminar fatos dos processos:

A jurisprudência da Suprema Corte é constante ao afirmar que a valoração da prova consubstancia questão de direito, condizente ao valor jurídico da prova ou a sua admissão em face da legislação. Distingue-se, portanto, do reexame da prova, que implica, 
necessariamente, a reapreciação do conjunto probatório com vistas a concluir-se se foram os fatos bem ou mal analisados. ${ }^{238}$

Mendes chama a abordagem consequencialista de análise de eventos futuros ou de prognoses, e afirma que "a legitimidade ou a ilegitimidade de uma dada lei depende da confirmação de um prognóstico fixado pelo legislador ou da provável verificação de um determinado evento". ${ }^{239}$ No mesmo sentido, Lenio Streck defende que leis que levem a resultados ruins não devem ser produzidas, e que essas consequências ou prognoses estão no espaço de controle do Judiciário. ${ }^{240}$

Nos casos expostos sobre a Corte alemã, os resultados previstos pelo legislador eram confrontados com os fatos previsíveis pela Corte, que se utilizava de peritos, dados estatísticos e documentos históricos para declarar a sua inconstitucionalidade.

Num dos casos citados por Gilmar Mendes, o Tribunal decidiu sobre uma norma que estabelecia um processo de admissão de dentistas, com vagas estabelecidas, restringindo a prática profissional. Justificava o governo naquela situação que havia um perigo na habilitação ilimitada de profissionais junto às caixas de assistência, o que levaria à redução dos rendimentos dos dentistas. Ao analisar os fatos, a Corte percebeu que naquele ano de 1959, 98\% dos dentistas já estavam filiados a algum tipo de caixa de assistência, e que o livre acesso, portanto, não causaria nenhum dos problemas apontados pelo governo para restringir o direito fundamental do livre exercício da profissão. ${ }^{241}$

Trazendo a discussão para o Brasil, poder-se-ia especular, por exemplo, no caso da arguição da inconstitucionalidade do exame da $\mathrm{OAB}$ como requisito ao exercício da advocacia, que o principal argumento favorável ao exame seria justamente o equilíbrio da oferta de mão de obra advocatícia, pois sem ele haveria uma enxurrada de novos profissionais, assim como no caso dos dentistas na Alemanha. Veja-se que a proposta de Gilmar Mendes de análise de prognoses está mais ligada a um controle judicial das

\footnotetext{
${ }^{238}$ MENDES, Gilmar. Anotações acerca da apreciação e revisão de fatos e prognoses legislativos perante a Corte Constitucional alemã e o Supremo Tribunal Federal brasileiro, in RAMOS, Elival da Silva; MORAIS, Carlos Blanco de (Coord.). Perspectivas de Reformas da Justiça Constitucional em Portugal e no Brasil. Coimbra: Almedina, 2012, p. 176.

${ }^{239}$ Idem, p. 160.

${ }^{240}$ STRECK, Lenio Luiz. Jurisdição Constitucional e Decisão Jurídica. $3^{\text {a }}$ ed. São Paulo: Revista dos Tribunais, 2013, p. 708.

${ }^{241}$ MENDES, Gilmar. Anotações acerca da apreciação e revisão de fatos e prognoses legislativos perante a Corte Constitucional alemã e o Supremo Tribunal Federal brasileiro, in RAMOS, Elival da Silva; MORAIS, Carlos Blanco de (Coord.). Perspectivas de Reformas da Justiça Constitucional em Portugal e no Brasil. Coimbra: Almedina, 2012, p. 163 e 164.
} 
consequências de uma norma debatida pelo Legislativo e Executivo do que propriamente a uma análise das consequências jurídicas das decisões.

Foram lançadas no capítulo passado algumas divergências em torno do consequencialismo no direito, que seriam: i) se argumentos consequencialistas devem ser usados em qualquer decisão ou apenas em casos difíceis; ii) se argumentos consequencialistas podem ser usados apenas quando não há normas tratando do caso, quando, por exemplo, há uma regra específica tratando da matéria; iii) no conflito entre argumentos consequencialistas e argumentos deontológicos, quais devem prevalecer; iv) que tipo de argumento consequencialista pode ser considerado no direito (apenas consequências jurídicas podem ser consideradas ou também consequências econômicas, sociais etc.); v) como aferir o peso das consequências para cada caso (e a questão da capacidade do juiz para decidir sobre tais pesos). E agora, por fim, estabelecer-se-á onde nos firmamos diante dessas divergências.

Sobre os pontos (i) e (ii), se argumentos consequencialistas devem ser usados em qualquer decisão ou apenas em casos difíceis, e se argumentos consequencialistas podem ser usados apenas quando não há normas tratando do caso, entendemos que devem ser usados em todas as decisões. Como dito no tópico anterior, pensar de modo consequencialista altera a percepção que se tem sobre o processo dedutivo das normas. $\mathrm{O}$ caráter argumentativo do direito, especialmente sob a perspectiva retórica, faz crer que a argumentação dedutiva não é sempre preponderante e o que pode convencer o magistrado e influenciar no seu processo cognitivo de interpretação varia de acordo com a matéria e a forma de exposição dos argumentos pelas partes - mesmo que sob a forma de entimemas, ou raciocínios não completos no sentido lógico - não sendo possível separar o processo interpretativo e justificador da norma incidente sobre o caso do uso de argumentos consequencialistas. Todas as decisões devem, nesse sentido, cumprir os três requisitos de uma boa fundamentação postos por MacCormick - coerência, consistência e consequências -, de forma que as consequências jurídicas devem sempre ser avaliadas.

Sobre o ponto (iii), pertinente ao conflito entre argumentos consequencialistas e argumentos deontológicos, não se pode dizer exatamente que argumentos deontológicos devem prevalecer sempre, sem correr o risco de simplificar exageradamente a justificação racional de uma decisão. Isto é, caso se parta da premissa de que o argumento consequencialista influencia o processo de criação da norma (judicial) e todas as decisões devem almejar, ao menos, não produzir efeitos nefastos para o ordenamento, não há problema no fato de que, eventualmente, argumentos consequencialistas prevaleçam numa 
decisão judicial. Muito embora, especialmente na realidade brasileira, seja mais adequado para o convencimento da decisão que ela se apoie claramente em argumentos deontológicos, que são, em geral, mais aceitos por todos os juristas.

Talvez o ponto (iv) seja o mais difícil de definir, sobre o limite entre o consequencialismo jurídico e o argumento consequencialista de cunho econômico ou social. Do ponto de vista retórico, é possível especular que argumentos consequencialistas de cunho econômico são menos convincentes do que argumentos consequencialistas jurídicos. Embora haja no Brasil alguns defensores da análise econômica do direito, ${ }^{242}$ quando se classifica um argumento como econômico certamente há uma perda da força para o convencimento. Especulando além do rótulo, o uso de argumentos consequencialistas de cunho econômico é comum, como o argumento de que a decisão inibiria investimentos estrangeiros, geraria desemprego etc., mas ainda assim é visto com reservas por boa parte dos autores.

Pode-se aqui ir além da proposta de Neil MacCormick e reconhecer um tipo de consequencialismo não expressamente aceito pelo autor escocês. Ter-se-ia como consequência jurídica - além de se prever a mensagem jurídica emanada da norma, isto é, o status jurídico provocado pela decisão no ordenamento como se ela fosse uma norma geral, ou melhor, um precedente para as ações humanas - a possibilidade de classificar como consequência jurídica as consequências econômicas e sociais que efetivamente são previsíveis e repercutem sobre o fato analisado, desde que protegidas por normas jurídicas.

No segundo caso, o típico consequencialismo jurídico é o previsto no mecanismo do controle de constitucionalidade que será exposto na segunda parte do trabalho, acerca da modulação de efeitos. Nesse exemplo, ainda mais forte que qualquer outro, o ordenamento jurídico brasileiro autoriza que o juiz ou o tribunal restrinja a produção de eficácia da norma desde que estejam ameaçados os valores juridicamente protegidos da segurança jurídica, ou do que a lei chama de "excepcional interesse social". Claramente há um instrumento a autorizar a análise puramente consequencialista, pois investiga as consequências previsíveis da decisão para alterar a aplicação da incidência da norma jurídica sobre o caso a critério do juiz. Ou seja, a norma dá liberdade para modular para frente, ou para trás, desde que cotejados tais conceitos jurídicos indeterminados.

Outro ponto central e complexo é o da aferição dos pesos de argumentos consequencialistas. Pode-se buscar a objetividade e criar um sistema onde seja possível

\footnotetext{
${ }^{242}$ Entre eles: CARVALHO, Cristiano. Teoria da Decisão Tributária. São Paulo: Saraiva, 2013.
} 
aferir quanto cada consequência seria pesada pelo juiz em cada caso. Tal esforço seria, no entanto, provavelmente inútil. Mas é possível pensar que, fortalecida a jurisprudência como "fonte do direito", 243 critérios possam ser criados pela reiteração de decisões, estabelecendo precedentes de como cada consequência pode e deve ser avaliada, sendo infrutífero nesse momento tratar genericamente de fórmulas universais para tal análise.

Nesta primeira parte do trabalho foram estabelecidos os marcos teóricos da tese, fundamentais para trabalhar os objetos de análise bem mais dogmáticos da segunda parte. O método de análise que se buscou aqui delimitar é o da retórica na argumentação jurídica, objetivando a identificação do argumento consequencialista nas decisões judiciais.

Nessa parte que se iniciará a seguir, tratar-se-á do objeto em si de análise, que são as normas orçamentárias no controle de constitucionalidade principal brasileiro. No primeiro capítulo da segunda parte, as normas orçamentárias serão delimitadas quanto à sua produção, conteúdo e natureza, especialmente no Brasil, como ponto de apoio para entender o seu controle de constitucionalidade, objeto do capítulo seguinte.

Em seguida, o trabalho se encaminha para o objetivo principal, fundados todos os conceitos necessários, que é a análise das decisões proferidas pelo Supremo Tribunal Federal no controle de constitucionalidade principal de normas orçamentárias, em busca dos argumentos consequencialistas, identificando também o movimento jurisprudencial e o estabelecimento de precedentes na área.

${ }^{243}$ No sentido usual, sem entrar no mérito da grande discussão de serem ou não fontes do direito a jurisprudência e doutrina. Sobre o assunto, ver: CARVALHO. Paulo de Barros. Direito Tributário: linguagem e método. $3^{\mathrm{a}}$ ed. Noeses: São Paulo, 2009, p. 413 e ss. 


\section{SEGUNDA PARTE: CONSEQUENCIALISMO NO CONTROLE DE CONSTITUCIONALIDADE DE LEIS E NORMAS ORÇAMENTÁRIAS NO BRASIL}

\section{LEIS E NORMAS ORÇAMENTÁRIAS NA CONSTITUIÇÃO DE 1988}

1.1. Conteúdo e disposição das Leis e Normas Orçamentárias

1.1.1 Plano Plurianual

1.1.2 Lei de Diretrizes Orçamentárias

1.1.3 Lei Orçamentária Anual

1.1.4 Créditos Adicionais

1.1.5 Medida Provisória em matéria orçamentária

1.2 Natureza Jurídica das Leis Orçamentárias no Brasil: ainda é possível falar em leis de efeitos concretos?

1.3 Qual o fundamento de validade das leis orçamentárias?

O objetivo deste capítulo é firmar o conteúdo das leis e normas orçamentárias no Brasil que são, por sua vez, o objeto do controle de constitucionalidade a ser examinado no capítulo seguinte.

A importância deste capítulo se dá em razão do debate acerca da natureza das leis orçamentárias, tidas no passado como instrumentos sem força normativa, ou seja, que apesar de veiculadas por lei do ponto de vista formal, não possuiriam conteúdo de lei.

Esse critério seria a essência do afastamento da possibilidade do controle de constitucionalidade sobre tais normas, causando grande risco à supremacia da Constituição.

\subsection{Conteúdo e disposição das Leis e Normas Orçamentárias}

O orçamento público é uma peça de planejamento e controle da atividade financeira estatal. Normas orçamentárias são normas jurídicas que regulam a atividade 
financeira do Estado, desde o momento da arrecadação, transferência, gestão e dispêndio dos recursos públicos. ${ }^{244}$ Aliomar Baleeiro chama o orçamento de

ato pelo qual o Poder Legislativo prevê e autoriza ao Poder Executivo, por certo período e em pormenor, as despesas destinadas ao funcionamento dos serviços públicos e outros fins adotados pela política econômica ou geral do país, assim como a arrecadação das receitas já criadas em lei. ${ }^{25}$

O conceito de Baleeiro apresenta algumas limitações, especialmente quando remete inteiramente a relação orçamentária aos Poderes Legislativo e Executivo como autorizante e autorizado, respectivamente. Mas traz noções essenciais como a ideia de periodicidade, inerente às leis orçamentárias, e a relação entre receita e despesa destinadas ao funcionamento dos serviços públicos.

A necessidade de lei para disposição das normas orçamentárias está ligada à sua origem, qual seja a de controle da atividade financeira do Estado pelo parlamento. Se no período anterior havia uma maior liberdade do rei para criar novos tributos e dispor as despesas públicas, com o fortalecimento das funções legislativas, e mais, do Legislativo como legítimo representante do povo na democracia indireta, passou-se a exigir a aprovação prévia de um orçamento como forma de submeter o rei ou chefe de Estado à vontade do povo.

As normas que definem e regulam a atividade orçamentária do Estado nascem, portanto, da necessidade de controle e hoje são instrumentos fundamentais no planejamento do Estado; têm, por isso, uma clara decisão política sobre quem receberá os recursos e quais as necessidades públicas a serem satisfeitas.

Leis orçamentárias são instrumentos normativos que têm por objetivo dispor o orçamento público. No Brasil, seguindo uma tradição e uma tendência mundial, as normas orçamentárias são dispostas por tais veículos, que são o principal instrumento jurídico, embora não o único, pelo qual esse tipo de norma pode ser veiculado.

Nosso país inclusive foi um dos pioneiros na adoção do modelo legal para o controle das finanças públicas, ainda no século XIX, logo após a Inglaterra, que produziu

\footnotetext{
${ }^{244}$ A atividade orçamentária compreende as fases de arrecadação, transferência, gestão e dispêndio dos recursos públicos. Existem diversas leis que regulam tais fases do orçamento. Há exemplos que regulam desde a arrecadação tributária até a execução de recursos públicos por meio dos precatórios.

${ }^{245}$ BALEEIRO, Aliomar. Uma Introdução à Ciência das Finanças. 14 ed. Rio de Janeiro: Forense, 1996, p. 387.
} 
seu primeiro orçamento público na década de 20. A Constituição brasileira de $1824^{246}$ já previa a produção de tais leis. O primeiro orçamento do governo central foi votado para o período de 1831 e 1832. Desde 1828, havia orçamento público na Corte e Província do Rio de Janeiro. $^{247}$

Na Itália, atualmente o artigo 81 do texto constitucional prevê vedações à lei orçamentária no estabelecimento de novos tributos e de novas despesas. ${ }^{248}$ Nesse país, portanto, a lei orçamentária não pode inovar o ordenamento jurídico, sendo subordinada ao direito preexistente. ${ }^{249}$

Tal limitação constitucional levou à criação em 1978 do que se chama de "lei financeira", livre dessas limitações reservadas às leis orçamentárias italianas, e que tem em seu domínio hoje justamente a criação de receitas e despesas. ${ }^{250}$

A Lei Fundamental da República Federal da Alemanha diz em seu artigo 110, item (2): "O orçamento é fixado pela lei orçamental para um ou mais anos económicos, separados por anos, antes do início do primeiro ano económico". 251

$\mathrm{Na}$ Alemanha, Tiago Duarte relata uma "divisão entre a lei do Orçamento (haushaltsgesetz) e o Orçamento propriamente dito (haushaltsplan)". A lei do orçamento é de natureza legislativa e limitada no conteúdo e no âmbito temporal de aplicação, além de subordinada ao Direito, no sentido de que não poderia alterá-lo. ${ }^{252} \mathrm{~A}$ aprovação parlamentar do orçamento seria apenas uma espécie de legitimação democrática do governo e da liderança política, sendo a lei do orçamento um programa de governo em forma de lei. ${ }^{253}$

\footnotetext{
${ }^{246}$ A Constituição de 1824 disciplinava o orçamento público da seguinte forma: "Art. 172. O Ministro de Estado da Fazenda, havendo recebido dos outros Ministros os orçamentos relativos ás despezas das suas Repartições, apresentará na Camara dos Deputados annualmente, logo que esta estiver reunida, um Balanço geral da receita e despeza do Thesouro Nacional do anno antecedente, e igualmente o orçamento geral de todas as despezas publicas do anno futuro, e da importancia de todas as contribuições, e rendas publicas".

${ }^{247}$ BALEEIRO, Aliomar. Uma Introdução à Ciência das Finanças. 14 ed. Rio de Janeiro: Forense, 1996, p. 393.

${ }_{248}$ "Con la legge di approvazione del bilancio non si possono stabilire nuovi tributi e nuove spese". ITÁLIA. La Costituzione della Repubblica Italiana. Disponível em: <http://www.governo.it/Governo/Costituzione/2_titolo1.html>. Acesso em 2.12.13.

${ }^{449}$ DUARTE. Tiago. A Lei por Detrás do Orçamento: a questão constitucional da lei do orçamento. Coimbra: Almedina, 2007, p. 300 e 303.

${ }^{250}$ Idem, p. 317.

${ }^{251}$ ROGEIRO, Nuno. A Lei Fundamental da República Federal da Alemanha: com um ensaio e anotações de Nuno Rogeiro. Coimbra: Coimbra editora, 1996, p. 230.

${ }^{252}$ Parte da doutrina defenderia um princípio da subordinação do orçamento ao Direito. DUARTE. Tiago. A Lei por Detrás do Orçamento: a questão constitucional da lei do orçamento. Coimbra: Almedina, 2007, p. 324.

${ }^{253}$ Idem, p. 328.
} 
Assim, na Alemanha, “a lei orçamental, contendo o respectivo Orçamento, é (ainda hoje) vulgarmente qualificada como mera lei organizatória (organgesetz), pertencendo ao domínio interno do Estado (innenbereich des States)". ${ }^{254}$ Isto é, para a generalidade da doutrina alemã, a lei orçamentária não poderia ser fonte de direitos nem de obrigações, e a inscrição em orçamento de uma despesa, embora requisito autorizativo, não poderia ser sua fonte legitimadora em que fosse exigida uma precedência de uma fonte legal material. ${ }^{255}$

Na França, segundo Bouvier, Esclassan e Lassale, há diferenças de ordem formal e material entre as leis orçamentárias e as demais leis do país, com regras mais restritas para votação no primeiro aspecto e cujos conteúdos não são exatamente disposições gerais e impessoais sem limitação temporal. Ressaltam, entretanto, que determinadas disposições que podem ser incluídas na lei orçamentária possuem caráter legislativo, em ambos os sentidos, formais e materiais. ${ }^{256}$

Uma característica marcante do sistema orçamentário na França, para os fins desta tese, é o processo de aprovação da lei orçamentária. Há duas fases distintas de discussão e aprovação. Na primeira fase, votada em bloco, cerca de $90 \%$ das destinações são aprovadas, sendo consideradas as receitas e despesas necessárias para a manutenção dos serviços como funcionaram no ano anterior. Na segunda fase são votadas as "measures nouvelles", que propõem aumentos ou diminuições de certas verbas,

aí se concentrando a discussão parlamentar e a análise das opções políticas subjacentes, não obstante a votação parlamentar se realizar, apenas, por títulos e por ministérios. Este sistema leva a que a atenção parlamentar se concentre, somente, nas variações propostas pelo Governo face às verbas já consagradas no Orçamento anterior, assim se ganhando em racionalização do tempo parlamentar o que se perde com o incentivo de uma perspectiva incremental do Orçamento e da estrutura do sector administrativo, desligada de qualquer ideia de reformulação da distribuição de verbas, tendo em conta novos objectivos ou missões da administração pública. ${ }^{257}$

O conteúdo da lei orçamentária na Espanha é mais amplo do que o verificado nos demais países analisados, inclusive o Brasil. Carreira Raya afirma que o conteúdo da

${ }^{254}$ DUARTE. Tiago. A Lei por Detrás do Orçamento: a questão constitucional da lei do orçamento. Coimbra: Almedina, 2007, p. 335.

${ }^{255}$ Idem, p. 336.

256 "Il faut ajouter cependant que certaines dispositions peuvent être incluses dans la loi de finances, revêtir un caractère législatif, au double sens, formel et matériel du terme". BOUVIER, M.; ESCLASSAN, M.; \& LASSALE, J. Finances Publiques. $8^{a}$ ed. Paris: LGDJ, 2002, p. 231.

${ }^{257}$ DUARTE. Tiago. A Lei por Detrás do Orçamento: a questão constitucional da lei do orçamento. Coimbra: Almedina, 2007, p. 353. 
lei orçamentária na Espanha é complexo e o divide em normas estritamente orçamentárias e normas não orçamentárias em sentido estrito, mas que possuem indubitável relação com as primeiras. ${ }^{258}$ Ferreiro Lapatza relata que normas que reformam o sistema tributário, autorizações para emissão de dívida pública e outras disposições que se distinguem nitidamente das normas orçamentárias podem ser encontradas naquele tipo de lei. ${ }^{259}$ Lá é possível, portanto, que a lei orçamentária contenha normas permanentes e não submetidas à periodicidade comum da lei que a veicula. Permitidas, portanto, as caudas orçamentárias. $^{260}$

Em Portugal, até a reforma da Constituição feita em 1982, havia um regime em que o orçamento não era completamente aprovado por lei. Desde 1933, havia uma divisão da "autorização política em lei de autorização das receitas e despesas ('leis de meios') e Orçamento Geral do Estado (aprovado por decreto simples: decreto orçamental)". ${ }^{261}$ A partir dessas reformas foi restrito o poder de decisão do Executivo e dada maior proeminência ao Legislativo, como deve ser em questões orçamentárias.

Nos dias de hoje, o artigo 105 da Constituição Portuguesa não estabelece limitações materiais à lei orçamentária. ${ }^{262}$ Do que se pode compreender do texto constitucional, especialmente desse artigo, não há matéria que não possa ser veiculada na lei que positiva o orçamento público. Tiago Duarte afirma ter a Constituição firmado um

${ }^{258}$ CARRERA RAYA, Francisco José. Manual de Derecho Financiero. Vol. III. Madrid: Tecnos, 1995, p. 17.

${ }^{259}$ FERREIRO LAPATZA, José Juan. Curso de Derecho Financiero Español. 25 a ed. Madrid/Barcelona: Marcial Pons, 2006, p. 203.

${ }^{260}$ No ano de 1988 havia inclusive uma norma na lei orçamentária que dispunha que todos os artigos que não estipulassem expressamente o seu caráter anual seriam dotados de vigência indefinida, invertendo a lógica da anualidade ou periodicidade da lei orçamentária. O Tribunal Constitucional declarou a inconstitucionalidade dessa norma. DUARTE. Tiago. A Lei por Detrás do Orçamento: a questão constitucional da lei do orçamento. Coimbra: Almedina, 2007, p. 386.

${ }^{261}$ SOUSA FRANCO, António L. de. Finanças Públicas e Direito Financeiro. Vol. I e II. $4^{\mathrm{a}}$ ed. Coimbra: Almedina, 2007, p. 391.

262 “Artigo 105. O Orçamento do Estado contém:

a) A discriminação das receitas e despesas do Estado, incluindo as dos fundos e serviços autónomos;

b) O Orçamento da segurança social.

2. O Orçamento é elaborado de harmonia com as grandes opções em matéria de planeamento e tendo em conta as obrigações decorrentes de lei ou de contrato.

3. O Orçamento é unitário e especifica as despesas segundo a respectiva classificação orgânica e funcional, de modo a impedir a existência de dotações e fundos secretos, podendo ainda ser estruturado por programas.

4. O Orçamento prevê as receitas necessárias para cobrir as despesas, definindo a lei as regras da sua execução, as condições a que deverá obedecer o recurso ao crédito público e os critérios que deverão presidir às alterações que, durante a execução, poderão ser introduzidas pelo Governo nas rubricas de classificação orgânica no âmbito de cada programa orçamental aprovado pela Assembleia da República, tendo em vista a sua plena realização". PORTUGAL. Constituição da República Portuguesa. Disponível em: <http://www.parlamento.pt/Legislacao/Paginas/ConstituicaoRepublicaPortuguesa.aspx>. $\quad$ Acesso $\quad \mathrm{em}$ 12.11.2013. 
conteúdo mínimo obrigatório, mas também um espaço razoavelmente flexível para outros conteúdos orçamentários. ${ }^{263}$

O Tribunal Constitucional de Portugal decidiu sobre a admissibilidade de caudas orçamentárias, ${ }^{264}$ lá chamadas cavaleiros orçamentais, reconhecendo que, "embora seja uma norma sem imediata incidência financeira (norma 'não orçamental'), a sua inserção na lei do Orçamento tem sido aceite como constitucionalmente admissível". ${ }^{265}$

Não há, portanto, uma vedação clara de veiculação de outras normas nas leis orçamentárias, apesar de se reconhecer que algumas normas, mesmo veiculadas pelas leis orçamentárias, não constituem matéria orçamentária, relacionada à atividade financeira do Estado, portanto.

O debate sobre o conteúdo das leis orçamentárias em outros países é relevante para entender as limitações do nosso modelo. Hoje, no Brasil, são três as espécies de leis orçamentárias dispostas pela Constituição Federal de 1988, que devem ser produzidas em todos os níveis da federação: União, estados e municípios. São elas o Plano Plurianual PPA, a Lei de Diretrizes Orçamentárias - LDO e a Lei Orçamentária Anual - LOA. Cada uma tem atribuições diversas e atinge objetivos específicos da administração pública quanto à previsão, programação e controle das contas estatais.

Elas se destacam das demais leis que definem normas orçamentárias por disporem de um regime próprio, periódico, específico para cada ente da federação, e estão intimamente ligadas à situação financeira destes entes, isto é, refletem diretamente opções políticas, econômicas e sociais que são tomadas pelos formuladores de políticas públicas.

É preciso que se entenda a sistemática de produção das leis orçamentárias para que fiquem esclarecidos os critérios para a realização do seu controle de constitucionalidade.

\subsubsection{Plano Plurianual}

Ricardo Lobo Torres ressalta um interesse crescente por planos que estabeleçam metas para as atividades financeiras estatais, especialmente nos países da Organização para a Cooperação e Desenvolvimento Econômico - OCDE, incluindo

${ }^{263}$ DUARTE. Tiago. A Lei por Detrás do Orçamento: a questão constitucional da lei do orçamento. Coimbra: Almedina, 2007, p. 421.

${ }^{264}$ Nesse caso, uma autorização legislativa em matéria processual penal (Acórdão 180/88).

${ }^{265}$ Apud DUARTE. Tiago. A Lei por Detrás do Orçamento: a questão constitucional da lei do orçamento. Coimbra: Almedina, 2007, p. 426. 
Inglaterra, Suécia, Dinamarca e Nova Zelândia, com reflexos e influências no direito brasileiro. $^{266}$

O Plano Plurianual é uma lei orçamentária eminentemente voltada para o planejamento da atividade estatal, de médio e longo prazo. A primeira espécie das leis orçamentárias analisadas é a que possui um período de vigência mais amplo, sendo, na verdade, o "mais abrangente dos instrumentos que compõem o orçamento". ${ }^{267} \mathrm{O}$ sistema brasileiro estabeleceu competências diversas para cada espécie de lei orçamentária, e cabe especificamente ao PPA estabelecer metas a médio prazo para as administrações públicas e controlar os gastos que demandem uma dilação maior no tempo.

O PPA cumpre os dois principais objetivos das leis orçamentárias, que são o de controle das contas públicas e o de planejamento da atividade estatal.

Controle das contas por ser obrigatória a inclusão de despesas que tenham duração maior que um ano. Por outro lado, Fernando Facury Scaff afirma que essa inclusão de previsão no PPA demonstra a importância do sistema de planejamento público na Constituição de $1988 .{ }^{268}$ Planejar e controlar são, portanto, dois lados de uma mesma moeda. Ao se planejar, inevitavelmente o Estado estabelece mecanismos de cumprimento e controle das metas porventura estabelecidas. O Plano Plurianual é, nesse sentido, um programa de Estado veiculado por lei de extrema importância jurídica.

Talvez seja o único plano periódico que está presente nos três níveis federativos no Brasil de elaboração própria de cada ente. Todos os demais planos formulados, nacionais, setoriais ou regionais previstos na Constituição, devem ser formulados em consonância com o PPA de cada ente.

O PPA é veiculado por lei a qual é relativamente simples em seu texto normativo. $^{269}$ Os artigos da lei tratam basicamente dos conceitos gerais utilizados nos programas dispostos em anexo. Os anexos dos PPA é que trazem efetivamente os programas que serão executados nos próximos quatro anos em cada ente federativo brasileiro.

No caso do PPA federal, por exemplo, cada programa traz informações sobre seus objetivos, dispondo metas periódicas e iniciativas para atingi-los, além de indicadores

266 TORRES, Ricardo Lobo. Tratado de Direito Constitucional Financeiro e Tributário. Vol. V. O Orçamento e a Constituição. Rio de Janeiro: Renovar, 2008, p. 81.

${ }^{267}$ ASSIS, Luiz Gustavo Bambini. Processo Legislativo e o Orçamento Público: função de controle do Parlamento. São Paulo: Saraiva, 2012, p. 207.

${ }^{268}$ SCAFF, Fernando Facury. A Constituição Econômica Brasileira em seus 15 anos, in SCAFF, Fernando Facury. Constitucionalizando Direitos: 15 anos da Constituição Brasileira de 1988. Rio de Janeiro: Renovar, 2003, p. 277.

${ }^{269}$ O Plano Plurianual federal vigente, disposto na Lei 12.593/2012, conta apenas com 22 artigos. 
para aferir os desempenhos na execução de cada programa. José Maurício Conti expõe as características do PPA vigente:

No PPA 2012-2015, atualmente vigente, coube ao Poder Executivo, com base no programa de governo, estabelecer diretrizes, definindo uma Visão Estratégica, que indica o horizonte de longo prazo almejado, e os Macrodesafios a serem enfrentados para atingi-lo. Com base nessas diretrizes, o PPA 2012-2015 constituiu Programas Temáticos e Programas de Gestão, Manutenção e Serviços ao Estado. ${ }^{270}$

Tão importante quanto a fixação de objetivos e programas pelo Plano Plurianual é a sua fiscalização e o acompanhamento do cumprimento de metas. Tais metas serão especificadas para o cumprimento no curto prazo pelas Leis de Diretrizes Orçamentárias e, finalmente, serão fixadas as despesas correspondentes nas Leis Orçamentárias Anuais para o cumprimento dos programas.

A grande questão que surge dessa noção é exatamente quais as consequências que decorrem da não observação ou do não cumprimento das regras. O PPA é um conjunto de normas autorizativas? Há níveis razoáveis de cumprimento? A LDO e a LOA precisam implementar as políticas efetivamente de acordo com o que dispõe cada PPA? Essas questões serão tratadas nos tópicos seguintes.

É preciso afirmar que o Plano Plurianual, veiculado por uma lei, tem todo o seu conteúdo vinculativo do comportamento do agente público e dispõe uma variedade de normas jurídicas, regras e princípios, que condicionam a atividade financeira dos municípios, estados e da União.

\subsubsection{Lei de Diretrizes Orçamentárias}

A Lei de Diretrizes Orçamentárias é um instrumento de planejamento estatal a curto prazo, bem como de introdução de normas no ordenamento jurídico financeiro, peculiar ao sistema orçamentário brasileiro. A LDO também cumpre as duas funções das leis orçamentárias, planejar a atividade estatal e controlar as contas públicas, além de funções anômalas, como, por exemplo, estabelecer percentuais de vinculação de receitas, orientando a elaboração da Lei Orçamentária Anual.

\footnotetext{
${ }^{270}$ CONTI, José Maurício. O Plano Plurianual - PPA, in Martins, Ives Gandra da Silva; MENDES, Gilmar F.; NASCIMENTO, Carlos Valder do. Tratado de Direito Financeiro. Volume 2. São Paulo: Saraiva, 2013, p. 327.
} 
A Lei de Diretrizes Orçamentárias é de instituição obrigatória para todos os entes públicos no Brasil, assim como as demais leis orçamentárias, e basicamente dispõe orientações para a elaboração das Leis Orçamentárias Anuais com base nas metas e objetivos previstos nos Planos Plurianuais.

Ricardo Lobo Torres critica veementemente a instituição das LDO no Brasil, afirmando tratar-se de modelo orçamentário oriundo de sistemas parlamentaristas e que teria trazido mais desvantagens que vantagens. Diz ainda que "as diretrizes básicas para a elaboração da proposta orçamentária sempre foram objeto de despacho do Presidente da República, que fixava, nos regimes constitucionais anteriores, os tetos para diversas despesas". 271

No entanto, quanto mais discutidas as questões orçamentárias, maiores as chances de efetivar a democratização das finanças públicas. Não só passam pelo crivo do Legislativo as disposições da LDO, como deveriam passar sempre pelo crivo do público em geral, e quanto mais ampla for a participação, melhor.

José Afonso da Silva esclarece bem o objetivo principal da LDO:

o plano plurianual estabelece uma programação de investimento para três ou quatro anos e prevê os recursos destinados a financiá-los no período, que devem ser executados em cada exercício financeiro por via da execução do orçamento anual, mas é a lei de diretrizes orçamentárias que vai dizer quais as metas e prioridades da administração pública em cada um desses exercícios. Quer dizer, ela faz a vinculação do plano plurianual com o orçamento de cada ano de sua vigência. ${ }^{272}$

O prazo de vigência desta lei é curioso e único. Isto porque a LDO é formulada num determinado ano para orientar a formulação da Lei Orçamentária Anual que será vigente no ano seguinte. O seu prazo para encaminhamento é de até oito meses e meio antes do encerramento do exercício financeiro, e o prazo para devolução para sanção é a data do encerramento do primeiro período da sessão legislativa. ${ }^{273}$ Isso deve ocorrer ainda no meio do ano, para que a discussão da Lei Orçamentária Anual seja feita com base no que foi por ela, LDO, disposto. No entanto, durante a execução da Lei Orçamentária Anual, no ano seguinte, a LDO continua vigente e orientando a sua aplicação. Assim, a vigência normal é de um ano e meio, podendo, como as demais leis orçamentárias, ter sua

${ }^{271}$ TORRES, Ricardo Lobo. Tratado de Direito Constitucional Financeiro e Tributário. Vol. V. O Orçamento e a Constituição. Rio de Janeiro: Renovar, 2008, p. 91.

${ }^{272}$ SILVA, José Afonso da. Orçamento-Programa, in Martins, Ives Gandra da Silva; MENDES, Gilmar F.; NASCIMENTO, Carlos Valder do. Tratado de Direito Financeiro. Volume 2. São Paulo: Saraiva, 2013, p. 119.

${ }^{273}$ Artigo 35 do ADCT da Constituição da República Federativa do Brasil de 1988. 
vigência alterada, seja pela demora na sua aprovação, seja pela demora na aprovação da LDO seguinte, levando à sua ultratividade.

As leis de diretrizes orçamentárias, assim como as demais leis orçamentárias, dispõem diversos tipos de normas, não apenas normas concretas, mas também normas abstratas. Observa-se um artigo da Lei de Diretrizes Orçamentárias para o ano de 2014:

\footnotetext{
Art. $8^{\circ}$ Todo e qualquer crédito orçamentário deve ser consignado diretamente à unidade orçamentária à qual pertencem as ações correspondentes, vedando-se a consignação de crédito a título de transferência a outras unidades orçamentárias integrantes dos Orçamentos Fiscal e da Seguridade Social. ${ }^{274}$
}

A partir desse texto é possível construir uma norma claramente abstrata, pois a incidência dela num momento não esgota a possibilidade de outra incidência sobre o caso. Tratar-se-á melhor do tema num tópico seguinte deste capítulo.

A LDO, entretanto, não é suficiente para autorizar e possibilitar a realização das despesas públicas. É preciso ainda uma última lei, que produz normas que possibilitam e vinculam diretamente as políticas produzidas pelo Estado, chamada Lei Orçamentária Anual.

\subsubsection{Lei Orçamentária Anual}

A Lei Orçamentária Anual é o instrumento normativo clássico que veicula o orçamento público. O que comumente se chama de orçamento público, no Brasil se trata da Lei Orçamentária Anual.

Assim como as demais espécies de lei orçamentária vistas anteriormente, todos os entes públicos brasileiros devem propor a LOA, neste caso com uma diferença na periodicidade, que é anual. Todos os municípios, estados e a União, portanto, devem elaborar e aprovar tais leis nos seus respectivos âmbitos de atuação.

As propostas das LOAs no Brasil são de iniciativa exclusiva do Poder Executivo. Cada Poder ou órgão com autonomia orçamentária, como as defensorias públicas, deve encaminhar seus projetos para o Executivo a fim de que o chefe desse Poder reúna as propostas, em atendimento à regra orçamentária da unidade, que exige seja o orçamento feito sempre em peça única.

${ }^{274}$ BRASIL. Lei nº 12.919/2013. 
A tramitação no Poder Legislativo, para quem o Poder Executivo deve encaminhar a proposta, varia a depender do ente federal que se trata. No caso da União Federal, a proposta é votada numa comissão mista.

A lei orçamentária anual deve ser aprovada até o dia 31 de dezembro do ano anterior ao da sua vigência, ${ }^{275}$ muito embora no Brasil, mesmo no plano federal, em grande parte dos anos sua aprovação ultrapasse tal data. ${ }^{276}$

A LOA, apesar do princípio da unidade orçamentária, é dividida em três “orçamentos" constitucionalmente previstos. ${ }^{277} \mathrm{O}$ orçamento fiscal, "referente aos Poderes da União, seus fundos, órgãos e entidades da administração direta e indireta, inclusive fundações instituídas e mantidas pelo Poder Público"; o orçamento de investimentos "das empresas em que a União, direta ou indiretamente, detenha a maioria do capital social com direito a voto"; e o orçamento da seguridade social, "abrangendo todas as entidades e órgãos a ela vinculados, da administração direta ou indireta, bem como os fundos e fundações instituídos e mantidos pelo Poder Público”.

O principal tema em relação à Lei Orçamentária Anual é, do ponto de vista deste trabalho, o do seu conteúdo. E um dos seus aspectos principais é o definido no parágrafo oitavo do artigo 165 da Constituição Federal, que dispõe:

A lei orçamentária anual não conterá dispositivo estranho à previsão da receita e à fixação da despesa, não se incluindo na proibição a autorização para abertura de créditos suplementares e contratação de operações de crédito, ainda que por antecipação de receita, nos termos da lei.

Apenas três conteúdos, dessa forma, têm a sua veiculação autorizada na lei orçamentária anual, conforme o referido dispositivo constitucional.

Em primeiro lugar, a receita, largamente tida como mera previsão, tem a função de autorizar ao menos a realização das despesas públicas, no montante previsto na própria lei orçamentária. No entanto, as disposições sobre receita nas leis orçamentárias efetivamente carecem de elevada eficácia jurídica, pois não é possível fixar novas receitas ou modificar as existentes por meio da lei orçamentária, e a não aprovação do orçamento não gera repercussões jurídicas no campo da arrecadação.

\footnotetext{
${ }^{275}$ A Lei Orçamentária Anual de 2015 deve ser aprovada até o dia 31 de dezembro de 2014.

${ }^{276}$ Embora não tenha ultrapassado em sua última aprovação em 2013.

${ }^{277}$ Artigo 165, $\$ 5^{\circ}$, da Constituição Federal.
} 
Em segundo lugar, a fixação das despesas, que em regra são normas autorizativas que constituem condição objetiva para a realização das despesas públicas. Segundo Gabriel Ivo:

A permissão decorre da proibição da inexistência do Estado. Negar a realização de despesas significa o mesmo que decretar a inexistência do Estado. Todavia, em outras situações, a despesa não é somente permitida, mas obrigatória. ${ }^{278}$

Sobre tal tipo de norma, em outro trabalho pudemos afirmar que:

a lei orçamentária dispõe autorizações ou obrigações de realizar gastos pela administração pública. Esse gasto, caso utilize o modal obrigatório, não poderá ser verificado simplesmente pela leitura da LOA. Apenas uma interpretação com base nos textos constitucionais e que leve em consideração as demais normas anteriores no processo de positivação pode aferir esta obrigatoriedade na realização do gasto. Em qualquer caso, sejam essas regras meramente autorizativas ou não, todas as normas que dispõem essas despesas são cogentes, isto é, obrigam o administrador público de alguma forma. ${ }^{279}$

As normas que dispõem despesas são normas concretas, não abstratas. São concretas porque a incidência da norma a esgota em alguma medida, não sendo infinitas as possibilidades de incidência desde que aconteça a hipótese da norma. Ou seja, quando fixada uma dotação orçamentária em 1 milhão de reais, uma vez realizados tais valores, a norma produz totalmente os efeitos pretendidos, ao contrário de uma norma que estipula a incidência de um tributo sobre uma determinada hipótese. Todas as vezes que ocorrido o fato gerador, deve ser a consequência. No caso da norma orçamentária que fixa despesa pública, há um esgotamento da incidência, o que leva a classificá-la como norma concreta. Nem por isso são menos "normas jurídicas" que outras normas mais abstratas.

Em terceiro, e por último, normas que tratem da autorização para abertura de créditos suplementares e contratação de crédito, as quais são normalmente normas gerais e abstratas que dispõem em que casos e em que limites pode se dar a criação de créditos suplementares e a contratação de crédito, ou dívida pública, pelo ente que as dispõe. Aqui, tantas vezes quantas forem criados créditos adicionais do tipo suplementar, haverá a incidência da norma.

\footnotetext{
${ }^{278}$ IVO, Gabriel . Direito Tributário e Orçamento Público, in Direito Tributário: homenagem a Paulo de Barros Carvalho. Luís Eduardo Schoueri (Org.). São Paulo: Quartier Latin, 2008, p. 886.

${ }^{279}$ CHRISTOPOUlOS, Basile. Despesa Pública: estrutura, função e controle judicial. Maceió: Edufal, 2011, p. 81 .
} 
O estabelecimento de limites ao conteúdo das leis orçamentárias na Constituição é usual e debatido nas doutrinas internacionais, como se verá no próximo tópico, especialmente em razão do perigo das chamadas caudas orçamentárias. Tiago Duarte cita outros nomes para tal fenômeno, como cavaleiros orçamentais, legislaçãoescova, furgão dos resíduos legislativos do ano. ${ }^{280}$

A ideia é a de vetar conteúdos não relacionados ao Direito Financeiro nas leis orçamentárias anuais, inseridos para se ter a certeza de sua aprovação junto com o texto da lei orçamentária em prazo definido e certo. O raciocínio é simples: como a lei orçamentária é votada e aprovada todos os anos, o legislador poderia aproveitar-se dessa situação para incluir outros temas controversos e impor a sua votação em conjunto com a lei que veicula orçamentos públicos. Tais restrições ao conteúdo da lei orçamentária, assim como em outros países analisados, podem levar à criação de leis de acompanhamento, ${ }^{281}$ trazendo normas que os orçamentos materialmente não estariam qualificados a dispor, mas que acompanhariam as leis orçamentárias nos momentos de votação para tratar de matérias vedadas ao orçamento.

Por fim, em relação aos objetivos da lei orçamentária, além da função constitucionalmente definida de introduzir as diretrizes definidas nos Planos Plurianuais na diminuição das desigualdades inter-regionais segundo o critério populacional, pode-se afirmar que a lei orçamentária anual instrumentaliza os direitos e garantias fundamentais estabelecidos na Constituição no que diz respeito à responsabilidade estatal, possibilitando o funcionamento dos serviços públicos que garantem tais direitos e financiando as necessidades públicas definidas em cada ente.

\subsubsection{Créditos Adicionais}

As leis orçamentárias são leis periódicas e preveem receitas e despesas para um futuro que pode ou não se concretizar. Para ajustar as leis orçamentárias a novas realidades imprevisíveis ou a novos interesses que surjam durante a sua execução, existem alguns mecanismos como a limitação de empenho. ${ }^{282}$ Mas certamente o que vale a pena tratar

\footnotetext{
280 DUARTE. Tiago. A Lei por Detrás do Orçamento: a questão constitucional da lei do orçamento. Coimbra: Almedina, 2007, p. 385.

${ }^{281}$ Idem, p. 400.

${ }^{282}$ A limitação de empenho constitui uma técnica financeira desenvolvida com o intuito de preservar os cofres públicos diante de certas situações. Seria uma vedação de assunção de novas despesas pelos entes estatais, e, portanto, na emissão de novas notas de empenho. CHRISTOPOULOS, Basile. Despesa Pública: estrutura, função e controle judicial. Maceió: Edufal, 2011, p. 123. E segundo Nóbrega tem origem no direito
} 
aqui, constituindo o mais importante mecanismo de adaptação orçamentária, é dos créditos adicionais.

Os créditos adicionais são mecanismos que alteram fundamentalmente a alocação das despesas públicas, indicando os recursos necessários para finalidades previstas ou não na formulação da lei orçamentária. Tais instrumentos são dispostos originalmente pela Constituição em diversos artigos e regulados pela Lei 4.320/64.

André Portella expõe quatro razões para a constituição de créditos adicionais: i) critério de conveniência e oportunidade da administração pública reconhecida pelo legislador; ii) erros de planejamento da atividade estatal; iii) eventos imprevisíveis; iv) decorrentes da dinâmica do processo de aprovação da lei orçamentária, que pode sofrer vetos, rejeições etc. ${ }^{283}$

O critério utilizado para distinguir as duas primeiras espécies de créditos adicionais é o da previsão ou não de determinada despesa na lei orçamentária, diferenciando as despesas para as quais já houve previsão e os recursos mostraram-se insuficientes, os chamados créditos suplementares, e para despesas não previstas, os créditos especiais. Ambas as espécies necessitam de aprovação prévia do Legislativo, como previsto no artigo 166 da Constituição Federal, ao contrário da última espécie de crédito adicional, os créditos extraordinários.

Esta espécie está prevista no artigo $167, \S^{\circ}$, da Constituição. ${ }^{284}$ Barroso e Mendonça fazem a interessante observação de que a Constituição não exige expressamente que a abertura de tais créditos venha acompanhada da indicação dos recursos necessários à sua realização, podendo tal medida ser apreciada em momento posterior, no Legislativo. Este tem a faculdade de apontar a origem dos recursos, embora na prática o Poder Executivo não tenha deixado de indicar nas medidas provisórias que propôs. ${ }^{285}$

A redação do dispositivo deixa, por outro lado, aberta a possibilidade de outras despesas não necessariamente vinculadas à guerra, comoção interna ou calamidade

americano do Budget Enforcement Act, criado em 1990, e conhecido por "sequestration". NÓBREGA, Marcos. Influências Internas e Externas da Lei de Responsabilidade Fiscal, in: FIGUEIREDO, Carlos Maurício; NÓBREGA, Marcos. Responsabilidade Fiscal: Aspectos polêmicos. Belo Horizonte: Fórum, 2006, p. 29.

${ }^{283}$ PORTELLA, André. Lei Orçamentária Anual - LOA, in Martins, Ives Gandra da Silva; MENDES, Gilmar F.; NASCIMENTO, Carlos Valder do. Tratado de Direito Financeiro. Volume 2. São Paulo: Saraiva, 2013, p. 363.

284 “A abertura de crédito extraordinário somente será admitida para atender a despesas imprevisíveis e urgentes, como as decorrentes de guerra, comoção interna ou calamidade pública, observado o disposto no art. 62”. BRASIL. Constituição da República Federativa do Brasil de 1988.

${ }^{285}$ BARROSO, Luís Roberto \& MENDONÇA, Eduardo. Sistema Constitucional Orçamentário, in Martins, Ives Gandra da Silva; MENDES, Gilmar F.; NASCIMENTO, Carlos Valder do. Tratado de Direito Financeiro. Volume 2. São Paulo: Saraiva, 2013, p. 253. 
pública, desde que cumpram os requisitos de imprevisibilidade e urgência no mesmo nível que tais conceitos apresentam. Barroso e Mendonça ressaltam, nesse sentido, que "embora a indicação não seja taxativa, a redação do dispositivo é clara no sentido de demonstrar que apenas despesas verdadeiramente emergenciais justificam a utilização do instrumento". ${ }^{286}$

Na Alemanha, dispositivo semelhante é previsto na Constituição, que em seu artigo 112 afirma: "as despesas excedentes e extraorçamentais carecem da aprovação do Ministro Federal de Finanças. Essa aprovação apenas pode ser dada no caso de uma necessidade imprevista e impreterível. A regulação poderá ser feita por lei federal". 287

A possibilidade de abertura de crédito extraordinário é absolutamente excepcional no ordenamento jurídico, justamente porque a aprovação do Poder Legislativo é feita a posteriori e não previamente à realização do gasto, sendo uma exceção também, portanto, à lógica da norma da separação dos Poderes que rege todo o direito financeiro. No entanto, o Poder Executivo tem abusado desse mecanismo, ferindo a citada noção de que a aprovação da lei orçamentária depende da participação central do Poder Legislativo, que fica nesses casos relegado a segundo plano, aprovando novas despesas apenas em momento posterior ao da sua vigência.

O mecanismo pelo qual a Constituição previu a possibilidade de introduzir créditos extraordinários no ordenamento, ao menos no plano federal, ${ }^{288}$ é o da medida provisória, objeto do tópico que se iniciará.

\subsubsection{Medida Provisória em matéria orçamentária}

As medidas provisórias são instrumentos de que dispõe o Presidente da República para, em casos de relevância e urgência, introduzir normas jurídicas com força de lei. ${ }^{289}$

Segundo José Levi do Amaral Júnior, a natureza da medida provisória seria de "ato normativo primário e provisório - circunscrito à esfera privativa de competência do Presidente da República, possuindo, desde logo, força, eficácia e valor de lei. Em suma, é

\footnotetext{
${ }^{286} \mathrm{Idem}$, Ibdem.

${ }^{287}$ ROGEIRO, Nuno. A Lei Fundamental da República Federal da Alemanha: com um ensaio e anotações de Nuno Rogeiro. Coimbra: Coimbra editora, 1996, p. 231.

${ }^{288}$ Nos demais casos, aplica-se a regra do artigo 44 da Lei 4.320/64: "Art. 44. Os créditos extraordinários serão abertos por decreto do Poder Executivo, que dêles dará imediato conhecimento ao Poder Legislativo". BRASIL. Lei 4.320/64.

${ }^{289}$ Art. 62 da Constituição Federal.
} 
materialmente lei". ${ }^{290} \mathrm{O}$ autor ainda afirma que, na prática, seria um "projeto de lei com eficácia antecipada". 291

José Levi do Amaral Júnior expõe razões para a existência dessas medidas originárias do Poder Executivo, que diante das necessidades contemporâneas, "pela natural lentidão do processo legislativo parlamentar", pelo seu "funcionamento descontínuo", ou pela "carência de meios técnicos dos seus quadros", ${ }^{292}$ suprem necessidades de regulação rápida de matérias urgentes e relevantes.

As medidas provisórias têm origem no chamado decreto-lei, presente em algumas Constituições brasileiras e que por sua vez tem grande influência do decreto-legge italiano. $^{293}$

Em Portugal ainda há a figura do decreto-lei como ato legislativo primário, isto é, de competência originária para regular algumas matérias. ${ }^{294}$ Segundo Canotilho, não há nenhuma restrição de conteúdo para tais atos, podendo qualquer matéria ser disciplinada pelo decreto-lei. ${ }^{295}$ Cristina Queiroz demonstra a complexidade que o tema ganhou em terras lusitanas, classificando os decretos-leis em primários, autorizados, de desenvolvimento, reservados e de transposição de diretivas comunitárias. ${ }^{296}$

É preciso relacionar o uso de tais medidas às Constituições dos períodos antidemocráticos no Brasil. Fernando Facury Scaff chega a afirmar que "o cerne do sistema legislativo desses períodos autoritários encontrava-se na figura dos decretos-lei". ${ }^{297}$ Nem a Constituição de 1891 nem a de 1934 trataram do instituto. A primeira a prever a competência do Presidente da República para a expedição dos decretos-leis foi a de 1937,

290 AMARAL JÚNIOR, José Levi M. do. Medida Provisória: edição e conversão em lei. São Paulo: Saraiva, 2012, p. 105 e 106.

${ }^{291}$ Idem, Ibdem. Esse conceito, de projeto de lei com eficácia antecipada, deve ser visto, no entanto, com grandes reservas. Apesar de as leis orçamentárias serem de votação obrigatória dentro de um determinado período no Congresso Nacional, é inequívoco que introduzem normas no ordenamento jurídico e que possuem efeitos relevantes e muitas vezes de impossível retroação.

${ }^{292}$ Idem, p. 35.

293 AMARAL JÚNIOR, José Levi M. do. Medida Provisória: edição e conversão em lei. São Paulo: Saraiva, 2012.

${ }^{294}$ CANOTILHO, J.J. Gomes. Direito Constitucional e Teoria da Constituição. $7^{\text {a }}$ ed. Coimbra: Almedina, 2000 , p. 795.

${ }^{295}$ Idem, Ibdem.

${ }^{296}$ Embora citada, a classificação não é de grande utilidade para o Brasil, por isso não há explicação sobre o que cada tipo significa. Para entender melhor a classificação, ver: QUEIROZ, Cristina. Direito Constitucional: as instituições do Estado Democrático e Constitucional. Coimbra: Coimbra Editora, 2009, p. 261.

${ }^{297}$ SCAFF, Fernando Facury. Quando as Medidas Provisórias se transformaram em Decretos-lei ou Notas sobre a Reserva Legal Tributária no Brasil, in SCAFF, Fernando Facury \& MAUÉS, Antonio G. Moreira. Justiça Constitucional e Tributação. São Paulo: Dialética, 2005, p. 87. 
outorgada por Getulio Vargas com as expressas justificativas, que acompanhavam a Constituição, de que esta atendia

\begin{abstract}
às legitimas aspirações do povo brasileiro à paz política e social, profundamente perturbada por conhecidos fatores de desordem, resultantes da crescente agravação dos dissídios partidários, que uma notória propaganda demagógica procura desnaturar em luta de classes, e da extremação, de conflitos ideológicos, tendentes, pelo seu desenvolvimento natural, a resolver-se em termos de violência, colocando a Nação sob a funesta iminência da guerra civil;

ao estado de apreensão criado no País pela infiltração comunista, que se torna dia a dia mais extensa e mais profunda, exigindo remédios, de caráter radical e permanente;

a que, sob as instituições anteriores, não dispunha o Estado de meios normais de preservação e de defesa da paz, da segurança e do bem-estar do povo;
\end{abstract}

Finalmente, com a expressão "Com o apoio das forças armadas" foi imposto o texto que previa na Constituição de 1937 :

expedir decretos-leis sobre as matérias de competência legislativa da União, excetuadas as seguintes:
a) modificações à Constituição;
b) legislação eleitoral;
c) orçamento;
d) impostos;
e) instituição de monopólios;
f) moeda;
g) empréstimos públicos;
h) alienação e oneração de bens imóveis da União. (grifo nosso)

Desde o começo, portanto, a matéria orçamentária era excluída da competência dos decretos-leis. Retorna-se, por ora, ao esforço histórico.

A Constituição de 1946, novamente democrática, assim como as Constituições de 1934 e 1891, não trouxe a disciplina do instituto.

Em 1967, já no período da ditadura militar brasileira, o decreto-lei voltou a ser previsto no artigo 49 da Constituição, no rol dos "processos legislativos". Porém, sem grande disciplina sobre a matéria.

Disciplina essa que veio com o incremento da violência da ditadura mediante a Emenda Constitucional $n^{\circ} 1$, de 1969, que modificou completamente a Constituição de 1967, considerando inclusive o seguinte: "decretado o recesso parlamentar, o Poder Executivo Federal fica autorizado a legislar sôbre tôdas as matérias, conforme o disposto no $\S 1^{\circ}$ do artigo $2^{\circ}$ do Ato Institucional no 5 , de 13 de dezembro de $1968^{\prime}$. 
Dispunha o artigo 55 com a redação dada pela Emenda:

Art. 55. O Presidente da República, em casos de urgência ou de interêsse público relevante, e desde que não haja aumento de despesa, poderá expedir decretos-leis sôbre as seguintes matérias:

I - segurança nacional;

II - finanças públicas, inclusive normas tributárias; e

III - criação de cargos públicos e fixação de vencimentos.

$\S 1^{\circ}$ Publicado o texto, que terá vigência imediata, o Congresso Nacional o aprovará ou rejeitará, dentro de sessenta dias, não podendo emendá-lo; se, nesse prazo, não houver deliberação, o texto será tido por aprovado. $\S 2^{\circ}$ A rejeição do decreto-lei não implicará a nulidade dos atos praticados durante a sua vigência.

É notável também que no auge da ditadura militar brasileira, a Constituição mais autoritária proibia o uso dos decretos-leis para aumentar despesas públicas, embora tenha autorizado o seu uso para disciplinar questões sobre finanças públicas e, até mesmo, normas tributárias.

Finalmente, na vigente Constituição Brasileira de 1988, há em sua redação original uma disposição sobre as medidas provisórias. Em seu momento inicial, a Constituição pouco falava da situação das medidas provisórias, dispondo apenas os requisitos da relevância e urgência, atribuindo-lhes a força de lei e a eficácia imediata que, contudo, caso não fossem convertidas em lei no prazo de trinta dias, perderiam, desde sua publicação, os efeitos produzidos.

No entanto, a breve regulação permitiu que fossem editadas medidas além da conta $^{298}$ o que motivou a edição da Emenda Constitucional de $\mathrm{n}^{\mathbf{o}} 32$, desta vez disciplinando em minúcias requisitos para as medidas provisórias. ${ }^{299}$

Esse breve relato das medidas provisórias no direito constitucional brasileiro demonstra a centralidade da matéria financeira em suas disposições. Sempre que os decretos-leis ou as medidas provisórias foram previstas, havia alguma menção a matéria orçamentária.

O uso de medidas provisórias em excesso é uma ofensa aos valores democráticos, e todos os governos desde a redemocratização vêm se utilizando desse

\footnotetext{
${ }^{298}$ Há o relato no mesmo sentido de que na Itália a vulgarização da decretação de urgência do decreto-legge teria levado à adoção de medidas restritivas pela legislação daquele país ainda em 31 de janeiro de 1926 . AMARAL JÚNIOR, José Levi M. do. Medida Provisória: edição e conversão em lei. São Paulo: Saraiva, 2012, p. 39.

299 "A prática institucional anterior à EC n. 32, de 2001, admitiu - e os exemplos não são poucos - medida provisória em matéria orçamentária”. Idem, p. 126.
} 
instrumento para regular matérias que nem sempre atendem aos requisitos de relevância e urgência exigidos na Carta. No caso de matéria orçamentária, a questão é ainda mais grave.

Como visto, o surgimento dos orçamentos e da necessidade de lei para a sua aprovação tem origem no controle das normas orçamentárias pelo parlamento como instância de representação indireta do povo. Dessa forma, as leis orçamentárias surgiram para que o Legislativo controlasse a atividade financeira do Estado tradicionalmente comandada pelo Executivo na pessoa do Imperador, Rei ou Presidente.

Passa-se agora ao texto vigente da Constituição Federal no que diz respeito à matéria orçamentária:

Art. 62. Em caso de relevância e urgência, o Presidente da República poderá adotar medidas provisórias, com força de lei, devendo submetê-las de imediato ao Congresso Nacional.

$\S 1^{\circ}$ É vedada a edição de medidas provisórias sobre matéria:

I - relativa a:

(...)

d) planos plurianuais, diretrizes orçamentárias, orçamento e créditos adicionais e suplementares, ressalvado o previsto no art. $167, \S 3^{\circ}$;

Fernando Facury Scaff ressalta algumas diferenças entre o antigo decreto-lei e a medida provisória, destacando que "o conceito indeterminado de 'segurança nacional' desapareceu, sendo incluído o de 'relevância', ao lado da 'urgência', que foi mantida" da redação anterior. Certamente não apenas a mudança de nome, mas também o período democrático atual fez com que às medidas provisórias fossem impostas restrições de adaptação.

José Afonso da Silva aponta que são dois os tipos de requisitos que devem cumprir as medidas provisórias. Os pressupostos formais, que são os citados requisitos da relevância e urgência, e os requisitos materiais, que são as restrições impostas no texto constitucional pela Emenda Constitucional no 32, de 2001. Esta, entre outras matérias, proibiu o uso de tais instrumentos para a veiculação de matéria orçamentária. ${ }^{300}$ Mas o referido artigo trata apenas como exceção a abertura de crédito extraordinário no caso de despesas imprevisíveis e urgentes, como as decorrentes de guerra, comoção interna ou calamidade pública. ${ }^{301}$

Somam-se, portanto, os requisitos da medida provisória com os do crédito extraordinário para gerar uma situação excepcionalíssima ao uso desses instrumentos

${ }^{300}$ SILVA, José Afonso. Curso de Direito Constitucional Positivo. 24 a ed. São Paulo: Malheiros, 2005, p. 532.

${ }^{301}$ Art. $167, \S 3^{\circ}$, da Constituição Federal. 
normativos no direito financeiro. Infelizmente, nos últimos anos tem-se visto a banalização do uso de medidas provisórias para o remanejamento indevido de despesas públicas na área federal, desvirtuando os citados artigos constitucionais; verifica-se também a violação da norma da separação dos Poderes, uma vez que o Poder Legislativo nesses casos, se não excluído, tem sua participação mitigada na escolha das necessidades públicas a serem satisfeitas por meio do orçamento público.

A última medida provisória dessa natureza foi a de $n^{\circ} 637$, publicada no diário oficial do dia trinta de dezembro de 2013, no penúltimo dia de execução orçamentária. Para se ter uma ideia do descompromisso com as regras constitucionais, um dos créditos foi criado para "Implantação e Modernização de Infraestrutura para Esporte Educacional, Recreativo e de Lazer". 302

O uso de medidas provisórias em $\mathrm{si}^{303}$ e especialmente em matéria orçamentária, distorce a necessidade de autorização do executor das políticas, transformando-o na única instância a decidir os rumos das despesas públicas, excluindo os tradicionais mecanismos de controle prévio e de participação popular indireta. Justamente quando se clama por uma participação maior do povo, diretamente, nas decisões orçamentárias, o Executivo Federal concentra ainda mais as decisões públicas sobre os gastos.

Essa breve abordagem acerca do uso de medidas provisórias em matéria orçamentária é importante para a tese na medida em que ficará demonstrada a importância das Ações Diretas de Inconstitucionalidade que julgaram questões relacionadas ao uso desses instrumentos em normas orçamentárias. Estas serão analisadas em capítulo próprio.

\subsection{Natureza Jurídica das Leis Orçamentárias no Brasil: ainda é possível falar em leis de efeitos concretos?}

É clássica a discussão sobre a natureza jurídica das leis orçamentárias no direito financeiro. Suas repercussões práticas para o tema deste trabalho, a possibilidade de

\footnotetext{
${ }^{302}$ BRASIL. Medida Provisória de no 637/2013.

${ }^{303}$ Há um caso recente em matéria tributária da Medida Provisória de nº 627, de 11 de novembro de 2013, que em seu artigo 98 dispõe: "Esta Medida Provisória entra em vigor em $1^{\circ}$ de janeiro de 2015, exceto os arts. 67 a 71 e 92 a 100, que entram em vigor na data de sua publicação". Ora, como explicar os requisitos de relevância e urgência para uma normatização que entrará em vigor de forma vinculante mais de um ano após a entrada em vigor da lei? Certamente há algo de inapropriado no instrumento escolhido, e os governos brasileiros deveriam ter mais cuidado com a proteção da democracia e da separação dos poderes, normas ameaçadas no contexto atual.
} 
controlar a sua constitucionalidade, são relatadas nos acórdãos que serão objeto de análise no último capítulo.

Discutir a natureza jurídica de um instituto pode ser confuso, em razão da pluricidade de significados ou da inexatidão da expressão "natureza jurídica". É preciso firmar o que se entende pela expressão neste tópico.

Por natureza jurídica tem-se a investigação sobre a classificação e os efeitos jurídicos produzidos por determinadas normas no ordenamento. Fixar a natureza jurídica de um instituto, portanto, é classificá-lo diante dos demais institutos, dando-lhe os principais e essenciais contornos.

É possível distinguir orçamento público de lei orçamentária. Os orçamentos públicos seriam conjuntos de normas que regulam a atividade financeira do Estado. Leis orçamentárias, por sua vez, seriam os instrumentos jurídicos pelos quais os orçamentos públicos são postos no sistema. A natureza jurídica da lei orçamentária não é apenas do orçamento público, mas também do veículo jurídico que o introduz no sistema jurídico. ${ }^{304}$

Régis Fernandes de Oliveira coloca a questão apresentando as diversas respostas para a natureza das leis orçamentárias, que poderiam ser: i) lei em sentido apenas formal; ii) lei em sentido apenas material; iii) lei formal e material; iv) simples ato administrativo, sem caráter de lei; v) lei em relação à receita e ato administrativo em relação à despesa; e vi) ato-condição, ${ }^{305}$ a que se acrescenta, por fim, vii) ato administrativo em relação à receita e lei em relação à despesa. ${ }^{306}$ A classificação é exaustiva dos modelos encontrados e por isso útil ao trabalho.

Em tese publicada com o título "A Lei por Detrás do Orçamento: a questão constitucional da lei do orçamento", Tiago Duarte ajuda a entender a origem da classificação das leis orçamentárias em leis meramente formais. Segundo o autor, o domínio tributário com o tempo teria se automatizado e se bifurcado da lei do orçamento, “separando a legalidade tributária (permanente), da legalidade orçamental (periódica)". 307

Uma vez que a tradição da legalidade orçamentária é voltada para a periodicidade, em razão, entre outras, da necessidade de planejamento, a legalidade

\footnotetext{
${ }^{304}$ Essa distinção remete a Paul Laband: "Il importe de faire une distinction entre la loi concernant l'etablissement du budget et le budget lui-méme que vient s'y ajouter comme annexe". LABAND, Paul. Le Droit Public de L'Empire Allemand. Paris: V. Giard \& E. Briere, 1904, p. 276.

${ }^{305}$ OLIVEIRA, Régis Fernandes. Curso de Direito Financeiro. $5^{\text {a }}$ ed. São Paulo: RT, 2013, p. 406.

${ }^{306}$ Esta opção não consta no livro citado, sendo acrescentada aqui pelo autor da tese.

307 DUARTE. Tiago. A Lei por Detrás do Orçamento: a questão constitucional da lei do orçamento. Coimbra: Almedina, 2007, p. 297.
} 
orçamentária perdeu a capacidade de inovar o sistema jurídico em algumas realidades, como a brasileira, levando a crer que seria uma legalidade menor, ou meramente formal.

Tiago Duarte ressalta que, embora a discussão sobre a distinção entre lei formal e lei material tenha perdido a sua preponderância,

precisamente ao nível orçamental, onde toda a polémica se iniciou, um enclave mal resolvido, onde ainda permanecem importantes vestígios de uma realidade que se julgava ultrapassada, mas que encontra nos textos constitucionais, na doutrina e na jurisprudência importantes apoios. ${ }^{308}$

A distinção entre lei formal e lei material, que deu origem aos diversos tipos classificatórios, teria surgido com Paul Laband, jurista do direito público do início do século XX, justamente no tratamento de matéria orçamentária.

Segundo Laband, o orçamento não contém nenhuma regra jurídica, nenhuma ordem ou proibição, sendo concernente apenas à gestão financeira do império. Seria o orçamento do ponto de vista formal uma lei, mas do ponto de vista material um plano de gestão. ${ }^{309}$ Laband claramente despreza a característica autorizativa das normas como um efeito jurídico propriamente, apenas considerando como jurídicas normas que proíbem ou obrigam condutas. Será visto ainda neste tópico por que essa visão é equivocada.

A doutrina francesa, segundo Ferreiro Lapatza, teria acatado a lição de Laband de que a lei orçamentária não seria uma lei material, porém determinada a definir que conteúdo tal instrumento normativo teria. ${ }^{310}$

Para Gaston Jèze, o orçamento seria um documento jurídico complexo, integrado por diversos atos de natureza diversa. ${ }^{311}$ Segundo Régis Fernandes de Oliveira, Jèze seria o criador da distinção entre ato-regra, situações gerais e impessoais; atosubjetivo, situações individuais e concretas; e ato-condição, situações em que a produção de efeitos necessita de uma condição intermediária que a possibilite. ${ }^{312}$

Ainda hoje, autores franceses, como Bouvier, Esclassan e Lassale, chamam a lei orçamentária naquele país de ato-condição, sendo por essência um ato de autorização,

\footnotetext{
308 DUARTE. Tiago. A Lei por Detrás do Orçamento: a questão constitucional da lei do orçamento. Coimbra: Almedina, 2007, p. 298.

309 "Ces effets doivent être déduits scientifiquement de la nature juridique du budget.C'est ici qu'apparaissent les consequences du principe d'après lequel le budget, quoique établi, au point de vue formel, comme une loi, est cependant non pas une loi, mas un plan de gestion. La nature juridique du budget. Le budget ne contient aucune règle juridique, aucun ordre, aucune defense". LABAND, Paul. Le Droit Public de L'Empire Allemand. Paris: V. Giard \& E. Briere, 1904, p. 289.

${ }^{310}$ FERREIRO LAPATZA, José Juan. Curso de Derecho Financiero Español. 25a ed. Madrid/Barcelona: Marcial Pons, 2006, p. 200.

${ }^{311}$ FONROUGE, Giuliani. Derecho Financiero. Vol. I. Buenos Aires: De Palma, 1962, p. 122.

312 OLIVEIRA, Régis Fernandes. Curso de Direito Financeiro. $5^{\text {a }}$ ed. São Paulo: RT, 2013, p. 407.
} 
necessário para a realização das normas financeiras de arrecadação e dispêndio dos recursos públicos. ${ }^{313}$

A classificação das leis orçamentárias como leis exclusivamente formais pressupõe sempre que não há substância normativa em seu conteúdo, seja porque a lei é um mandato conferido ao Executivo para arrecadar e gastar, seja como instrução para os seus funcionários executores, determinando suas obrigações inerentes à função. ${ }^{314}$ Para os autores que defendem ter a lei orçamentária apenas a característica formal, portanto, o seu conteúdo seria meramente contábil, ${ }^{315}$ sem poder de inovar o ordenamento jurídico. $\mathrm{O}$ fato de algumas Constituições proibirem que as leis orçamentárias criem novas receitas, despesas ou qualquer outro tipo de norma, sendo apenas instrumentos de consolidação daquilo que já existe, seria um importante elemento para caracterizar a mera formalidade de lei, sem nenhum conteúdo materialmente normativo.

Giuliani Fonrouge sugere que o objetivo da caracterização das leis orçamentárias como leis formais seria o de negar ao Poder Legislativo o direito absoluto e ilimitado de votar o orçamento, por não conceber a negativa de que caberia apenas ao Executivo conduzir os elementos necessários para a manutenção do Estado. Nada melhor, segundo ele, do que uma teoria que permite eliminar faculdades soberanas do parlamento, afirmando ser o orçamento uma simples norma de administração. ${ }^{316}$ Aduz Francisco Carrera Raya que ao Poder Legislativo corresponde a suprema decisão financeira, e, especificamente, a decisão orçamentária. E chega a dizer que no âmbito orçamentário haveria, portanto, a supremacia financeira do Poder Legislativo. ${ }^{317}$

Laband, por outro lado, nunca negou a característica formal das leis orçamentárias, no sentido de que a força formal das leis orçamentárias é absolutamente igual à de qualquer outra lei. ${ }^{318}$ Dino Jarach também afirma que não se pode colocar em xeque o fato de que as leis orçamentárias possuem um caráter formal, mesmo que não

\footnotetext{
${ }^{313}$ BOUVIER, M.; ESCLASSAN, M.; \& LASSALE, J. Finances Publiques. $8^{\text {a }}$ ed. Paris: LGDJ, 2002, p. 230 e 231.

${ }^{314}$ FONROUGE, Giuliani. Derecho Financiero. Vol. I. Buenos Aires: De Palma, 1962, p. 122.

315 Interessante, nesse sentido, a expressão de Carrera Raya, para quem a lei orçamentária tem a missão característica de dotar de valor e eficácia jurídica as previsões contábeis do Estado. CARRERA RAYA, Francisco José. Manual de Derecho Financiero. Vol. III. Madrid: Tecnos, 1995, p. 16.

${ }^{316}$ FONROUGE, Giuliani. Derecho Financiero. Vol. I. Buenos Aires: De Palma, 1962, p. 121.

${ }^{317}$ CARRERA RAYA, Francisco José. Manual de Derecho Financiero. Vol. III. Madrid: Tecnos, 1995, p. 15.

318 "La dorce formelle de loi de la loi du budget est absolument la méme que celle des autres lois". LABAND, Paul. Le Droit Public de L'Empire Allemand. Paris: V. Giard \& E. Briere, 1904, p. 294.
} 
exclusivo, ${ }^{319}$ uma vez que a evolução histórica desta instituição teria culminado com a necessidade de aprovação pelo parlamento de uma lei em sentido estrito. ${ }^{320}$

Ferreiro Lapatza questiona, superada a noção de que a lei orçamentária é lei pelo menos formal, qual seria o seu conteúdo material, se de ato legislativo, se de ato por meio do qual se realiza a função legislativa, ou um ato em que se integram ao ordenamento novas normas jurídicas. ${ }^{321}$ Considera que afirmar que a lei orçamentária não seria uma lei em sentido material seria afirmar que esta não introduziria normas jurídicas no ordenamento. Negar a tese de que a lei orçamentária não seria lei material levaria, consequentemente, à necessidade de provar que a lei orçamentária contém normas jurídicas e que tais normas disciplinam a atividade interna da administração pública, bem como perante terceiros, e as relações que dela derivam. ${ }^{322}$ Conclui que a lei orçamentária seria lei tanto no sentido formal quanto material, e também que tal consideração depende da análise do sistema orçamentário de cada país. ${ }^{323}$

Ricardo Lobo Torres defende que no sistema constitucional brasileiro as leis orçamentárias continuam apresentando características ainda de lei exclusivamente formal: "A teoria de que o orçamento é lei formal, que apenas prevê as receitas públicas e autoriza os gastos, sem criar direitos subjetivos e sem modificar as leis tributárias e financeiras, é, a nosso ver, a que melhor se adapta ao direito constitucional brasileiro". 324 O autor reconhece as críticas à distinção entre leis formais e materiais, mas afirma que tal discrímen ainda é necessário para entender as leis orçamentárias, com a consequência relevante para o controle de constitucionalidade de tais normas, que o autor entende não passível em razão da sua natureza política. ${ }^{325}$

Giuliani Fonrouge, indo além, afirma ser um ato que regula a vida econômica e social do país, com significação jurídica e não meramente contábil, fonte de direitos e obrigações para a administração e produtor de efeitos em relação aos particulares. ${ }^{326}$

\footnotetext{
${ }^{319}$ No mesmo sentido, FERREIRO LAPATZA, José Juan. Curso de Derecho Financiero Español. $25^{\text {a }}$ ed. Madrid/Barcelona: Marcial Pons, 2006, p. 199.

${ }^{320}$ No mesmo sentido, Aliomar Baleeiro afirma que "Formalmente, o orçamento não difere das demais leis". BALEEIRO, Aliomar. Uma Introdução à Ciência das Finanças. 14ª ed. Rio de Janeiro: Forense, 1996, p. 414.

${ }^{321}$ FERREIRO LAPATZA, José Juan. Curso de Derecho Financiero Español. 25 a ed. Madrid/Barcelona: Marcial Pons, 2006, p. 199.

${ }^{322}$ Idem, p. 201.

${ }^{323}$ Idem, p. 202 e 203.

324 TORRES, Ricardo Lobo. Tratado de Direito Constitucional Financeiro e Tributário. Vol. V. O Orçamento e a Constituição. Rio de Janeiro: Renovar, 2008, p. 96.

325 Idem, Ibdem.

${ }^{326}$ FONROUGE, Giuliani. Derecho Financiero. Vol. I. Buenos Aires: De Palma, 1962, p. 131.
} 
Citando Livio Paladin, num livro de 1969, Tiago Duarte afirma que as concepções materiais da lei orçamentária seriam "reduzidas às suas características de generalidade, abstracção e novidade". ${ }^{327}$ Nesse sentido, para que uma lei pudesse ter conteúdo material, ela deveria trazer normas novas ao ordenamento, ou seja, novos tributos e receitas e/ou novas despesas, além de possuir os requisitos de abstração e generalidade.

A começar pelo aspecto da novidade. Como visto, em alguns sistemas orçamentários europeus as leis orçamentárias não podem inovar o sistema jurídico, apenas consolidar normas que foram anteriormente previstas, exercendo um papel mais contábil que normativo. A capacidade de inovação no ordenamento consistiria, portanto, na possibilidade de dispor normas que alterem o ordenamento jurídico.

Sem dúvida, qualquer documento que se pressupõe normativo deve inovar o ordenamento jurídico, veiculando normas jurídicas. Por esse motivo é que não existem leis interpretativas, que supostamente apenas esclarecem outra norma já posta. Todo novo texto normativo, se carrega essa característica, inova no ordenamento jurídico. No entanto, difícil é encontrar um texto normativo que não inove no ordenamento, ainda que seja num aspecto menor de qualquer norma jurídica. Apesar de verdadeiro, é de se questionar se o quesito é útil.

Quanto à generalidade e abstração, a expressão está diretamente ligada à ideia do título deste item, que é o de "leis de efeitos concretos". Ou seja, é muito provável que determinados diplomas normativos, a própria doutrina e a jurisprudência, quando citam a expressão "leis de efeitos concretos", mesmo que erroneamente, tenham em mente a classificação sedimentada pelo jurista italiano Norberto Bobbio, segundo a qual as normas poderiam ser gerais ou individuais, em relação aos seus destinatários, e abstratas ou concretas, quanto à possibilidade de esgotamento da eficácia das normas em relação à sua incidência. Dessa forma, normas destinadas a todos de maneira irrestrita seriam gerais, enquanto normas cujos destinatários fossem individuais, ou ao menos individualizáveis, seriam chamadas individuais. Pelo segundo critério, normas que uma vez realizada a sua incidência completa, sua eficácia se esgotaria, seriam chamadas de concretas, enquanto as abstratas poderiam incidir tantas vezes quantas fossem realizadas as descrições dos antecedentes das normas.

${ }^{327}$ DUARTE. Tiago. A Lei por Detrás do Orçamento: a questão constitucional da lei do orçamento. Coimbra: Almedina, 2007, p. 307. 
Hans Kelsen diz que uma norma tem caráter individual quando uma conduta única é individualmente obrigada; e geral, quando certa conduta universalmente é posta como devida. ${ }^{328}$

Norberto Bobbio ensina que gerais são as normas universais quanto aos seus destinatários; e abstratas aquelas universais em relação à ação. ${ }^{329}$ Esclarece ainda o autor italiano sobre o que o STF debate quando trata do tema das leis orçamentárias e será visto no último capítulo:

Julgamos que a consideração da generalidade e abstração como requisitos essenciais da norma jurídica tenham uma origem ideológica e não lógica, isto é, julgamos que por trás desta teoria haja um juízo de valor do tipo: "é bom (é desejável) que as normas jurídicas sejam gerais e abstratas". ${ }^{330}$

Além da classificação entre normas gerais e abstratas, individuais e concretas, há outra que classifica em três tipos possíveis as normas jurídicas. Normas proibitivas, obrigatórias e autorizativas. As normas autorizativas não podem ser desprezadas como fez Laband. O modo autorizativo da norma é essencial, especialmente no âmbito do poder público, onde o conhecido brocardo jurídico de que tudo que não está autorizado está proibido no âmbito da administração ainda tem algum sentido relevante. ${ }^{331}$ Essas possibilidades de normas - permissões $(\mathrm{P})$, proibições $(\mathrm{V})$ e obrigações $(\mathrm{O})$ - são os chamados modais deônticos das normas jurídicas. ${ }^{332}$

Passando a tratar exclusivamente na natureza das leis orçamentárias no sistema brasileiro, pode-se afirmar que as leis orçamentárias, falando genericamente nas três espécies, são instrumentos normativos que veiculam diversos tipos de normas.

As leis orçamentárias são certamente leis únicas e diferentes das demais leis. Elas possuem diversas características que as diferenciam das demais, seja pelo processo de aprovação, seja pelo conteúdo, seja pelos prazos de vigência. Régis Fernandes de Oliveira faz um apanhado bastante completo e interessante sobre tais peculiaridades das leis orçamentárias no Brasil:

Em primeiro lugar, há prazos para que seja encaminhado pelo Executivo ao Legislativo (art. $35, \S 2^{\circ}$, do ADCT). Demais, não pode ser objeto de

\footnotetext{
${ }^{328}$ KELSEN, Hans. Teoria Geral das Normas. Porto Alegre: Fabris, 1986, p. 10.

${ }^{329}$ BOBBIO, Norberto. Teoria da Norma Jurídica. Bauru: Edipro, 2001, p. 180 e 181.

${ }^{330}$ Idem, p. 182.

331 A frase não é exata, no sentido de que não corresponde totalmente à verdade, mas demonstra a importância que se dá às normas autorizativas no âmbito público.

${ }^{332}$ Que não se confundem com o deôntico do dever-ser, que não é modalizado, como visto no segundo capítulo da primeira parte da tese.
} 
lei delegada (art. 68, § $1^{\circ}$, III, da CF). O descumprimento da lei orçamentária resulta em responsabilidade do Presidente da República (art. 85, VI), cabendo-lhe iniciar o processo legislativo (art. 84, XXIII). Há uma série de restrições previstas na destinação de recursos (art. 167), bem como as emendas são limitadas (art. 166, $\S 3^{\circ}$ ) e tem tramitação própria perante o Congresso Nacional. Tem conteúdo limitado à despesa e receita (art. 165, § $8^{\circ}$ ). São estas algumas das peculiaridades orçamentárias, sem prejuízo de outras existentes em dispositivos esparsos da Constituição. Vê-se, pois, que não é uma lei comum. É uma lei diferente. ${ }^{333}$

No entanto, apesar de tais características, provar-se-á que, mesmo pelos critérios ultrapassados da distinção entre lei formal e lei material, as três leis orçamentárias no Brasil cumprem tais requisitos, a começar pelo Plano Plurianual.

Afirma Ricardo Lobo Torres que "O Plano Plurianual é lei formal, dependente do orçamento anual para que possa ter eficácia quanto à realização das despesas". ${ }^{334} \mathrm{Em}$ sentido inverso, Eros Roberto Grau, em livro sobre planejamento econômico, a afirma que lei que aprova as diretrizes e prioridades que condicionam o comportamento do setor público em matéria orçamentária e financeira, tem caráter de lei em sentido material. ${ }^{335}$

Assim como as demais leis orçamentárias, ao Plano Plurianual é atribuída a natureza meramente formal da lei. O Plano Plurianual, todavia, veicula artigos que produzem normas de diversas naturezas, inclusive principiológica. Muito distantes de um suposto efeito concreto, como a redação do PPA vigente até o ano de 2015 dispõe:

Art. $4^{\circ}$ O PPA 2012-2015 terá como diretrizes:

I - a garantia dos direitos humanos com redução das desigualdades sociais, regionais, étnico-raciais e de gênero;

II - a ampliação da participação social;

III - a promoção da sustentabilidade ambiental;

IV - a valorização da diversidade cultural e da identidade nacional;

$\mathrm{V}$ - a excelência na gestão para garantir o provimento de bens e serviços à sociedade;

VI - a garantia da soberania nacional;

VII - o aumento da eficiência dos gastos públicos;

VIII - o crescimento econômico sustentável; e

IX - o estímulo e a valorização da educação, da ciência e da tecnologia. ${ }^{336}$

\footnotetext{
${ }^{333}$ OLIVEIRA, Régis Fernandes. Curso de Direito Financeiro. $5^{\text {a }}$ ed. São Paulo: RT, 2013, p. 406.

334 TORRES, Ricardo Lobo. Tratado de Direito Constitucional Financeiro e Tributário. Vol. V. O Orçamento e a Constituição. Rio de Janeiro: Renovar, 2008, p. 81.

${ }^{335}$ GRAU, Eros Roberto. Planejamento Econômico e Regra Jurídica. São Paulo: Revista dos Tribunais, 1978, p. 230.

${ }^{336}$ BRASIL. Lei no 12.593 , de 18 de janeiro 2012.
} 
Desse artigo do Plano Plurianual da União Federal podem ser construídas diversas normas jurídicas, possivelmente mais próximas a um princípio do que a uma regra, distantes, e muito, de efeitos concretos.

Dada a criação de programas ou dotações orçamentárias, deve ser o aumento da eficiência dos gastos públicos. É possível chamar uma norma com essa estrutura de programática, mas nunca de concreta. Em toda norma criada sobre ela incidirá a consequência da necessidade de aumento da eficiência dos gastos públicos. São múltiplas e infinitas incidências, a priori, e não esgotáveis em razão da ocorrência da hipótese normativa.

No caso das Leis de Diretrizes Orçamentárias, é possível afirmar, assim como no caso anterior do Plano Plurianual, que a grande maioria das normas não é de efeitos concretos, ou, melhor, é de natureza abstrata e possui multiplicidade de incidências não finitas.

No caso da Lei 12.708/2012, que dispõe a Lei de Diretrizes Orçamentárias de 2013, tem-se o seguinte artigo que evidencia tal afirmação:

Art. 46. O Poder Executivo poderá, mediante decreto, transpor, remanejar, transferir ou utilizar, total ou parcialmente, as dotações orçamentárias aprovadas na Lei Orçamentária de 2013 e em créditos adicionais, em decorrência da extinção, transformação, transferência, incorporação ou desmembramento de órgãos e entidades, bem como de alterações de suas competências ou atribuições, mantida a estrutura programática, expressa por categoria de programação, conforme definida no $\S 1^{\circ}$ do art. $5^{\circ}$, inclusive os títulos, descritores, metas e objetivos, assim como o respectivo detalhamento por esfera orçamentária, grupos de natureza de despesa, fontes de recursos, modalidades de aplicação e identificadores de uso e de resultado primário.

A partir desse texto é possível formular apenas normas de natureza abstrata e não concreta. Basicamente temos a possibilidade abstrata de, em caso de incorporação ou desmembramento de órgãos e entidades, bem como de alterações de suas competências ou atribuições, o Poder Executivo remanejar mediante decreto, portanto sem autorização legislativa, os recursos controlados por aqueles órgãos. Nada, portanto, que uma vez realizado o fato gerador da norma, seus efeitos se exauram como requer uma norma de natureza concreta.

Por fim, as Leis Orçamentárias Anuais, apesar de possuírem, diferentemente das demais, um número acentuado de normas concretas, há também nelas uma pluralidade de normas que possuem naturezas distintas, sendo algumas também de natureza abstrata. 
Em relação à LOA, será feita uma exposição em separado quanto ao seu conteúdo: receitas, despesas e créditos adicionais, espécies de normas que compõem no Brasil uma lei orçamentária. ${ }^{337}$

Giuliani Fonrouge esclarece que, na visão de Jèze, normas sobre receita apenas seriam ato-condição quando fossem requisito para a arrecadação. Quando não, careceriam de significação jurídica. ${ }^{338}$ Infelizmente as leis orçamentárias não autorizam a cobrança de tributos, como parece sugerir Aliomar Baleeiro. ${ }^{339}$ Isto é, mesmo sem a efetiva aprovação da lei orçamentária, hoje não há nenhuma repercussão no Brasil para a cobrança dos tributos e das demais receitas estatais.

No caso brasileiro, pode-se afirmar, em relação às receitas, que tais normas desempenham um papel relacionado à previsão de um futuro incerto. Previsão de receitas, no entanto, não se amolda à ideia de uma norma que dispõe algum dos modais deônticos, (v) proibido, $(p)$ permitido e $(o)$ obrigatório. Para que seja norma jurídica, o texto que dispõe a previsão de receitas precisa servir de base para a construção de alguma norma que disponha a conduta humana.

Segundo Dino Jarah, no caso das receitas, nem sequer um ato de autorização seria, tendo em vista que se trataria apenas de uma previsão carente de importância jurídica. ${ }^{340}$ Isto é, a lei orçamentária, um nada normativo, produziria no campo das receitas tão só uma previsão contábil.

Diante disso, a principal disposição jurídica que se pode formular a partir do texto que trata das receitas que serão auferidas pelo Estado é uma autorização para destinar tais recursos por meio das despesas públicas também previstas nas leis orçamentárias. Isto é, todas as disposições sobre receita que constam numa lei orçamentária produzem um efeito jurídico, ou ao menos podem ser formuladas enquanto norma jurídica para dizer o quanto poderá ser destinado por meio das despesas públicas, seja no valor global, seja em cada previsão de arrecadação vinculada a uma determinada destinação.

\footnotetext{
337 O Tribunal Constitucional espanhol se posicionou expressamente sobre tal discussão, afirmando na Sentença 27/1981 que equiparar a lei do orçamento a uma lei em sentido formal não seria relevante e não traduziria a realidade daquele momento, superando a distinção entre lei formal e lei material. DUARTE. Tiago. A Lei por Detrás do Orçamento: a questão constitucional da lei do orçamento. Coimbra: Almedina, 2007, p. 377.

${ }^{338}$ FONROUGE, Giuliani. Derecho Financiero. Vol. I. Buenos Aires: De Palma, 1962, p. 122.

${ }^{339}$ BALEEIRO, Aliomar. Uma Introdução à Ciência das Finanças. 14a ed. Rio de Janeiro: Forense, 1996, p. 417.

${ }^{340}$ JARACH, Dino. Finanzas Públicas y Derecho Tributário. Caracas: Ediciones Nuevo Mundo Siglo XXI, 2007, p. 79 e 80.
} 
Se a Lei Orçamentária Anual do Brasil prevê que em 2015 serão arrecadados 10 bilhões em receita de Contribuição de Intervenção no Domínio Econômico - CIDEcombustíveis, as normas que tratarão das despesas na área dos transportes e que envolvam a materialidade da destinação específica daquele tributo estão autorizadas a dispor tais recursos em suas finalidades. De forma que, se a mesma LOA diz que a previsão de arrecadação será de 1 trilhão de reais, entende-se autorizada a realização de despesas públicas no mesmo montante pelo poder público federal, em consonância com o princípio do equilíbrio orçamentário, que prevê que as despesas só podem ser realizadas na medida em que sejam dispostas receitas suficientes para tanto.

Outra norma jurídica que pode ser construída, entre muitas outras no que diz respeito à receita, é uma norma de modal obrigatório, consistente na fixação de receitas para os demais Poderes em relação ao Poder Executivo, de forma que os valores fixados para efeito de transferência pelo sistema de duodécimos serão obrigatórios, independentemente, até mesmo, da efetiva arrecadação, como já decidiu o STF em algumas oportunidades. ${ }^{341}$

Não se pode concordar, portanto, que as normas sobre receitas dispostas pela LOA no Brasil não possuem característica normativa. Do texto normativo positivado por tais leis extraem-se diversas normas jurídicas, inclusive com modais deônticos diversos, não apenas meramente autorizativos.

No caso das despesas públicas, Dino Jarach afirma que seriam normas que apenas disporiam autorizações, sem conteúdo de normas materiais, constituindo meramente um ato administrativo. Mas conclui o autor pelo caráter obrigatório do orçamento, consistindo numa lei de eficácia obrigatória para os diferentes Poderes no que lhes diz respeito em sua execução, e que o conteúdo da lei orçamentária seria diverso das demais leis, mas sua essência seria de um marco legal dentro do qual deve se desenvolver a ação do governo. ${ }^{342}$

As despesas públicas são indubitavelmente normas jurídicas que estipulam como os comportamentos humanos devem ser em determinadas situações, especialmente, mas não exclusivamente, dos servidores públicos.

Em primeiro lugar, podem-se classificar as normas que dispõem despesas públicas como normas concretas, pelos critérios da classificação de Norberto Bobbio. Isso

\footnotetext{
${ }^{341}$ STF. MS 23.267-3/SC. Relator Min. Gilmar Mendes. Publicado no DJ 16.5.2003.

342 JARACH, Dino. Finanzas Públicas y Derecho Tributário. Caracas: Ediciones Nuevo Mundo Siglo XXI, 2007, p. 79 e 80.
} 
porque a incidência das normas que tratam de despesas se esgota, parcial ou totalmente, a cada aplicação. Isto é, quando a norma que estipula uma despesa é aplicada, ela esgota ao menos parte da sua possibilidade de incidir novamente.

Há um padrão normativo para a formulação de despesas públicas enquanto normas previstas nas leis orçamentárias anuais. No entanto, nem todas as normas que veiculam despesas são meramente autorizativas:

(...) despesas públicas, ao contrário do que se pensa, podem ser construídas com a utilização de dois dos três modais deônticos, o permitido e o obrigatório, mas não com o proibido. Isso porque as normas que dispõem as despesas não precisam trazer nenhuma proibição, visto que ela estará sempre numa norma anterior de estrutura. ${ }^{343}$

Tem-se por fim um terceiro tipo de norma trazida em leis orçamentárias anuais, que se insere na norma autorizativa constante no artigo $165, \S 8^{\circ}$, da Constituição Federal: “autorização para abertura de créditos suplementares e contratação de operações de crédito, ainda que por antecipação de receita, nos termos da lei." Todas as normas que podem ser produzidas a partir desse trecho do texto constitucional são normas gerais e abstratas, além de apresentarem o modal deôntico permitido.

Como exemplo, há a norma produzida com base nessa disposição constitucional na lei orçamentária vigente no ano de 2013. Que assim disciplina:

Art. $4^{\circ}$ Fica autorizada a abertura de créditos suplementares, restritos aos
valores constantes desta Lei, excluídas as alterações decorrentes de
créditos adicionais, desde que as alterações promovidas na programação
orçamentária sejam compatíveis com a obtenção da meta de resultado
primário estabelecida no Anexo de Metas Fiscais da LDO-2013 e sejam
observados o disposto no parágrafo único do art. $8^{\circ}$ da LRF e na LDO-
2013 e os limites e as condições estabelecidos neste artigo, vedado o
cancelamento de quaisquer valores incluídos ou acrescidos em
decorrência da aprovação de emenda individual ou de bancada estadual,
para o atendimento de despesas.

É possível observar, em primeiro lugar, que a norma claramente opta pelo modal permissivo, isto é, a partir do texto é possível criar uma norma que autoriza a abertura de créditos suplementares desde que cumpridos certos requisitos como o limite estabelecido no resultado primário do anexo de metas fiscais.

${ }^{343}$ CHRISTOPOULOS, Basile. Despesa Pública: estrutura, função e controle judicial. Maceió: Edufal, 2011, p. 83.

${ }^{344}$ BRASIL. Lei no $12.798 / 2013$. 
Essa norma é também classificável como uma norma abstrata. Normas concretas, como visto, seriam normas cuja incidência seria esgotável. Nesse caso, tantas vezes quantas forem criados créditos suplementares, a norma incidirá, ou seja, infinitamente, tendo em vista que não há uma redução total ou parcial da sua possibilidade de incidência.

Observando o ordenamento jurídico brasileiro especificamente, é possível argumentar com segurança que as três leis orçamentárias inovam o ordenamento jurídico. Elas possuem matérias específicas e próprias, não podem inovar o ordenamento em qualquer campo ou matéria, mas naquelas matérias de sua competência. As leis orçamentárias produzem normas que alteram a realidade jurídica, ainda que limitadas ao período de sua vigência.

Não é possível, como será visto no capítulo seguinte, afirmar que as leis orçamentárias de qualquer natureza ou espécie seriam normas de efeitos concretos, embora as referidas leis veiculem muitas normas gerais e concretas, como as que dispõem despesas. Em geral, o grau de abstração das normas é, como visto, variável a depender da lei, da análise particular de cada norma, sendo impossível rechaçar a priori, pelo critério da concretude de uma lei orçamentária, o seu controle de constitucionalidade.

\subsection{Qual o fundamento de validade das leis orçamentárias?}

O fundamento de validade, segundo Kelsen, não é outra coisa senão o seu modo particular de existência. ${ }^{345}$

A pergunta que este tópico pretende responder é basicamente o que dá o suporte ou fundamento do conteúdo material das normas orçamentárias. Isto é, como as leis orçamentárias situam a sua pertinência ao sistema, ou sua existência no sentido kelseniano.

As leis orçamentárias possuem um sistema de positivação no direito brasileiro muito peculiar. A Constituição Federal de 1988 estabeleceu que não apenas as leis orçamentárias devem seguir um procedimento legislativo especial, como que o seu conteúdo deve ser vinculado ao disposto pelas demais leis orçamentárias. Isso quer dizer

${ }^{345}$ KELSEN, Hans. Teoría Pura Del Derecho. Buenos Aires: Editorial Universitaria de Buenos Aires, 1960, p. 35. 
que o disposto no Plano Plurianual deve ser vinculante à futura disposição na Lei de Diretrizes Orçamentárias, que por sua vez vincula o conteúdo da Lei Orçamentária Anual.

A pesquisa do fundamento de validade das leis orçamentárias é relevante para o questionamento sobre seu controle de constitucionalidade. Todo controle de constitucionalidade tem por fundamento o questionamento da validade de uma lei perante a Constituição de um determinado país. No caso das leis orçamentárias, o disposto no artigo 166, $\S 4^{\circ}$, do texto constitucional levaria a crer que o conteúdo das leis orçamentárias anuais seria condicionado pelo texto das demais leis orçamentárias, isto é, que o seu fundamento de validade seria o conteúdo das leis de diretrizes orçamentárias e dos Planos Plurianuais.

Embora pareça, à primeira vista, que o fundamento de validade das leis orçamentárias seria ao menos em parte retirado das demais leis, as três leis orçamentárias retiram seu fundamento de validade diretamente da Constituição Federal. Desse modo, embora o conteúdo efetivamente tenha de respeitar o disciplinado pelas leis orçamentárias anteriores, no caso de descumprimento há uma ofensa ao dispositivo constitucional, passível, portanto, de controle de constitucionalidade.

Embora o planejamento da ação governamental se estruture em três leis da mesma hierarquia (as leis ordinárias do plano plurianual, das diretrizes orçamentárias e o orçamento anual), e portanto sem vínculo de subordinação formal entre si, a interpretação permite reconhecer haver vínculo entre elas. ${ }^{346}$

Dessa forma, é possível afirmar que quando uma Lei Orçamentária Anual dispõe algo claramente confrontante com o disposto na Lei de Diretrizes Orçamentárias ou no Plano Plurianual, ocorre uma inconstitucionalidade passível de controle, inclusive principal, como se verá no capítulo seguinte.

Mas surgem, nesse contexto, outras questões que serão abordadas agora. O que fazer quando há conflito entre conteúdo das leis orçamentárias? Há hierarquia entre os conteúdos das leis orçamentárias em seus diversos tipos? Leis orçamentárias podem dispor em sentido inverso ao de outras leis ordinárias?

Como visto, o artigo 166, $4^{\circ}$, da Constituição Federal estabelece que as emendas ao projeto da LDO não podem descumprir o disposto no PPA. Mas há uma

\footnotetext{
${ }^{346}$ CONTI, José Maurício. O Plano Plurianual - PPA, in Martins, Ives Gandra da Silva; MENDES, Gilmar F.; NASCIMENTO, Carlos Valder do. Tratado de Direito Financeiro. Volume 2. São Paulo: Saraiva, 2013, p. 328 .
} 
compreensão maior desse dispositivo no sentido de que as leis orçamentárias foram assim previstas na Constituição para desenvolver, em cada nível federativo, um objetivo de planejamento da atividade estatal. Não há sentido em prever tais leis e uma delas produzir normas incompatíveis com as anteriores. Se o PPA fixa metas para o quadriênio, é aceitável presumir que a LOA ao menos preveja o cumprimento de tais metas ao longo de cada ano. Uma vez detectada qualquer incompatibilidade entre as leis orçamentárias, constata-se uma violação aos dispositivos constitucionais citados, que podem ser arguidos judicialmente.

Sobre a segunda questão, pode-se afirmar que não há hierarquia entre os conteúdos das leis orçamentárias no Brasil. Cada uma possui competência razoavelmente diversa da outra. E tendo em vista que todas as leis buscam o seu fundamento de validade e a sua pertinência na Constituição, o disposto no PPA não pode ser considerado hierarquicamente superior ao disposto na LOA, embora as disposições da LOA devam seguir as normas previamente fixadas no PPA, sob pena, como dito, de inconstitucionalidade.

Por fim, leis orçamentárias, como definido no tópico anterior, são veículos de introdução de normas jurídicas no ordenamento. No entanto, a competência material das leis orçamentárias, de maneira geral, é bem diversa da competência das demais leis ordinárias de um país, estado ou município.

Em alguns países, como visto, as leis orçamentárias não são capazes de inovar o ordenamento, o que não é, contudo, o nosso caso. Dentro da sua competência material, as leis orçamentárias podem dispor diversamente de outras leis ordinárias já postas. Fala-se em leis ordinárias não porque se supõe que as leis complementares tenham hierarquia superior, pois essas também buscam seu fundamento de validade na Constituição, mas porque as leis complementares exercem uma competência bem delimitada na Constituição, a exemplo da Lei de Responsabilidade Fiscal, cujo conteúdo deve ser seguido pelas leis orçamentárias em todo o país, sob pena também de contrariar disposição constitucional.

Cabe agora tratar diretamente do controle de constitucionalidade brasileiro, com foco exclusivo em questões relacionadas ao controle principal de leis orçamentárias, como requisito deontológico para compreender as ações que julgaram a constitucionalidade de normas e leis orçamentárias no Brasil. 


\section{CONTROLE DE CONSTITUCIONALIDADE DAS LEIS E NORMAS ORÇAMENTÁRIAS NO BRASIL}

2.1 Controle de constitucionalidade no Brasil: características e limites

2.2 Eficácia das decisões do Supremo Tribunal Federal e modulação de efeitos no controle principal

2.3 Instrumentos processuais do controle de constitucionalidade principal das leis e normas orçamentárias no Brasil

2.3.1 ADI, ADC e ADO: o controle de constitucionalidade de leis e atos normativos

2.3.2 ADPF

2.4 Controle de constitucionalidade de leis e normas orçamentárias

Neste capítulo será analisado o controle de constitucionalidade no Brasil, especialmente no que diz respeito ao - e tem repercussão sobre o - controle de leis e normas orçamentárias. Dessa forma, não se pretende uma análise completa do sistema brasileiro de controle de constitucionalidade, mas a escolha de temas específicos que interessem na construção de um modelo "adequado" ao controle da constitucionalidade das normas dessa natureza.

\subsection{Controle de constitucionalidade no Brasil: características e limites}

Os sistemas de controle de constitucionalidade foram desenvolvidos para proteger o princípio da supremacia da Constituição. A partir do momento em que as Cartas Constitucionais passaram a exercer um protagonismo nos ordenamentos jurídicos, os sistemas de seu controle foram desenvolvidos para garantir sua defesa. Mas, segundo Mauro Cappelletti,

embora não expressa e conscientemente configurada como "supremacia da Constituição" em relação às leis ordinárias, existiu, no entanto, também em outros e mais antigos sistemas jurídicos, uma espécie de supremacia de uma dada lei ou de um dado corpo de leis - que, em terminologia moderna, poderemos, exatamente, chamar de leis "constitucionais" ou "fundamentais", Grundgesetze - em relação às 
outras leis que, sempre em terminologia moderna, podemos chamar leis "ordinárias". ${ }^{347}$

Elival da Silva Ramos afirma que seria um "autêntico consenso doutrinário" a ideia de que a "supremacia das normas constitucionais está na base da fundamentação teórica do controle de constitucionalidade". ${ }^{348} \mathrm{Na}$ mesma linha, Ruy Barbosa afirma que:

Esta consequencia resulta evidentemente da propria essencia do systema. Onde se estabelece uma Constituição, com delimitação da auctoridade para cada um dos grandes poderes do Estado, claro é que estes não podem ultrapassar essa auctoridade, sem incorrer em incompetencia, o que em direito equivale a cahir em nullidade. ${ }^{349}$

De início houve resistência europeia ao controle jurisdicional de constitucionalidade em razão da legitimidade parlamentar como representante da soberania popular e da ligação do Judiciário às antigas monarquias absolutistas no momento de transição: "Não seria de esperar que o Parlamento, após celebrar a histórica vitória sobre o poder monárquico que lhe era adverso, consentisse que outro Poder viesse a tolher, de algum modo, sua principal atividade, a elaboração legislativa", ${ }^{350}$ pois "O princípio da supremacia da lei, enquanto expressão da vontade geral, embora distinto, apresenta nítida imbricação com o princípio da supremacia do Parlamento (...)”."351

Certamente essa resistência europeia pode ser transcrita para o controle de leis orçamentárias, leis que claramente surgiram da ascensão do Legislativo e da necessidade de controle sobre o Executivo das opções públicas de receitas e despesas. Não é de admirar que o Legislativo tenha imposto restrições ao controle judicial do orçamento a fim de manter intacta a sua competência para decidir tais questões.

Mauro Cappelletti afirma que o controle de constitucionalidade das leis não teria surgido na Europa, mas nos Estados Unidos da América. "Antes, de fato, nunca teria

\footnotetext{
${ }^{347}$ CAPPELLETTI, Mauro. O Controle Judicial de Constitucionalidade das Leis no Direito Comparado. $2^{\mathrm{a}}$ ed. Porto Alegre: Sérgio Antonio Fabris Editor, 1999, p. 48.

348 RAMOS, Elival da Silva. Controle de Constitucionalidade no Brasil: perspectivas e evolução. São Paulo: Saraiva, 2010, p. 19.

${ }^{349}$ BARBOSA, Ruy. Os Actos Inconstitucionaes do Congresso e do Executivo ante a Justiça Federal. Rio de Janeiro: Companhia Impressora, 1893, p. 42 e 43.

${ }^{350}$ RAMOS, Elival da Silva. Controle de Constitucionalidade no Brasil: perspectivas e evolução. São Paulo: Saraiva, 2010, p. 124.

${ }^{351}$ Idem, p. 126.
} 
acontecido que um sistema de controle de validade das leis fosse confiado à obra dos tribunais e que tivesse, portanto, caráter judicial". ${ }^{352}$

Há dois modelos mundiais que foram seguidos pelos países para proteger a Constituição: o sistema americano e o austríaco. Cada um oferece vantagens e desvantagens, e, na verdade, há uma tendência de aproximação dessas duas vertentes, visível inclusive no Brasil.

Os sistemas de controle de constitucionalidade costumam ser classificados como difusos, concentrados ou mistos. Os de origem estadunidense são classificados como difusos, por permitirem que qualquer juiz declare ou constitua a inconstitucionalidade de uma lei, enquanto os concentrados, com origem na Áustria, e influenciados pelo jurista Hans Kelsen, delegam a um único órgão a responsabilidade de instituir a inconstitucionalidade.

Em relação a essa classificação, Jorge Miranda elenca as vantagens e desvantagens de cada sistema. No sistema difuso, a questão da inconstitucionalidade se daria naturalmente como questão jurídica e não política, permitindo assim uma maior eficácia da Constituição, porém com o risco da desarmonia dos julgados e uma possível desvalorização dos julgamentos de inconstitucionalidade. No sistema concentrado, haveria a vantagem da certeza do direito e uniformidade, evidentes pela exclusividade no controle de constitucionalidade, além de uma formação de jurisprudência enriquecedora do conteúdo constitucional. Como revés, o perigo das pressões políticas advindas do Executivo e Legislativo, o risco da imutabilidade jurisprudencial e uma "desproporção ante as necessidades de decisão jurídica a satisfazer”, deixando a Constituição exclusivamente às interpretações e valores dos tribunais constitucionais. ${ }^{353}$

Segundo Jorge Miranda, a fiscalização concentrada pode envolver não apenas um único órgão, mas um número reduzido de órgãos responsáveis sobre o controle de constitucionalidade. ${ }^{354}$ Por outro lado, Elival Ramos, Louis Favoreu e Cappelletti entendem apenas ser concentrado o regime quando um único órgão realiza o controle da constitucionalidade das normas infraconstitucionais.

\footnotetext{
${ }^{352}$ CAPPELLETTI, Mauro. O Controle Judicial de Constitucionalidade das Leis no Direito Comparado. $2^{\mathrm{a}}$ ed. Porto Alegre: Sérgio Antonio Fabris Editor, 1999, p. 46.

${ }^{353}$ MIRANDA, Jorge. Manual de Direito Constitucional: inconstitucionalidade e garantia da Constituição. Tomo IV. $4^{\circ}$ ed. Coimbra: Coimbra Editora, 2013, p. 139 e 140.

${ }^{354}$ Embora ambos concordem que o sistema brasileiro seja difuso, e não misto. Para o entendimento de Jorge Miranda, ver: MIRANDA, Jorge. Manual de Direito Constitucional: inconstitucionalidade e garantia da Constituição. Tomo IV. $4^{\circ}$ ed. Coimbra: Coimbra Editora, 2013.
} 
Não haveria uma natureza mista ou dúplice do sistema de controle de constitucionalidade no Brasil, mas um sistema difuso em que qualquer juiz pode declarar a inconstitucionalidade de uma lei:

\begin{abstract}
Destarte, para saber se determinado sistema de controle é difuso ou concentrado, considera-se o aparato jurisdicional no seu todo e verifica-se de quem é a competência para efetuar o controle da constitucionalidade das leis: se houver uma dispersão dessa competência, de sorte que qualquer juiz ou tribunal, de conformidade com os critérios pelos quais a massa de causas existentes no País lhes é distribuída, esteja habilitado, em tese, a fazer controle de constitucionalidade, o sistema é difuso; ao contrário, se apenas a um tribunal é confiada a competência para a fiscalização de constitucionalidade das leis, o sistema é concentrado. ${ }^{355}$
\end{abstract}

Elival Ramos afirma que deve ser feita uma análise sistêmica para se chegar à conclusão de qual regime é adotado em cada país, e no Brasil o sistema seria indubitavelmente difuso, já que reconhecida a qualquer juiz ou tribunal, respeitadas as regras de competência, a possibilidade de efetuar o controle de conformidade das leis à Constituição: ${ }^{356}$ "a difusão constitui traço característico da fiscalização jurisdicional da constitucionalidade no Brasil, presente desde a sua implantação, contemporânea ao nascimento da República, até os dias atuais". ${ }^{357}$ Nestes casos, haveria ainda assim um sistema de controle de constitucionalidade difuso, sendo a competência dos Tribunais como o STF em termos de ADI, por exemplo, apenas uma questão de divisão de competências, o que parece bastante razoável.

Pelo mesmo motivo, José Afonso da Silva assevera que o Supremo Tribunal Federal não pode ser considerado uma verdadeira Corte Constitucional no Brasil. Em parte pela seleção de seus membros, e em parte mais relevante "porque não é o único órgão jurisdicional competente para o exercício da jurisdição constitucional, já que o sistema perdura fundado no critério difuso (...)". 358

Quanto ao sistema adotado no Brasil, melhor do que falar em controle difuso e concentrado para diferenciar os dois modos de análise da constitucionalidade das leis e atos normativos, é falar em controle incidental e principal.

\footnotetext{
${ }^{355}$ RAMOS, Elival da Silva. Controle de Constitucionalidade no Brasil: perspectivas e evolução. São Paulo: Saraiva, 2010, p. 68.

${ }^{356}$ Idem, p. 68 a 70.

${ }^{357}$ RAMOS, Elival da Silva. A Evolução do Sistema Brasileiro de Controle de Constitucionalidade e a Constituição de 1988, in RAMOS, Elival da Silva; MORAIS, Carlos Blanco de (Coord.). Perspectivas de Reformas da Justiça Constitucional em Portugal e no Brasil. Coimbra: Almedina, 2012, p. 65.

${ }^{358}$ SILVA, José Afonso da. Curso de Direito Constitucional Positivo. 24a ed. São Paulo: Malheiros, 2005, p. 358 .
} 
O incidental, "em maior ou menor escala, sempre será de natureza concreta, em qualquer de suas modalidades", enquanto o principal, "desenvolvido por meio de processos constitucionais de controle, intitulados de ações diretas, adquire, em geral, feições abstratas". 359

No Brasil, de início, apenas se contava com o controle incidental de constitucionalidade. A partir da Emenda Constitucional nº 16/65 à Constituição de 1946, o sistema brasileiro "passou a combinar a técnica da declaração incidental, em concreto, consagrada no sistema modelar estadunidense, com a da fiscalização em abstrato da constitucionalidade das leis e atos normativos, de inspiração europeia". ${ }^{360}$

As características mais marcantes, a priori, do sistema de controle de constitucionalidade na Constituição de 1988 seriam: i) majoritariamente jurisdicionalrepressivo, com reduzida importância do controle preventivo e político; ii) difusão da competência do controle por todo o Judiciário; iii) combinação dos controles principal e incidental, o primeiro em processos abstratos e objetivos, com efeito erga omnes, e o segundo em processos concretos e subjetivos, com efeito inter partes; iv) nulidade com efeitos ex tunc, desde o início e não a partir da decisão ou de outro momento fixado pela decisão. ${ }^{361}$

Muitas dessas características, no entanto, embora subsistam, estão perdendo força, especialmente os itens iii) e iv), por instrumentos como a repercussão geral, que objetiva o controle incidental, e a modulação de efeitos, que relativiza o efeito ex tunc das decisões proferidas nesse tipo de controle. É identificada por diversos autores uma tendência inversa no controle incidental, chamada de abstração ou objetivação. ${ }^{362}$

Um dos sinais dessa tendência é a repercussão geral que, segundo Bruno Dantas, é um pressuposto específico de cabimento do recurso extraordinário, inserido, portanto, no juízo de admissibilidade desse recurso. ${ }^{363}$

Instrumentos como a repercussão geral do direito brasileiro são tendências mundiais diante do crescente aumento do acesso à justiça e da universal compreensão,

\footnotetext{
359 RAMOS, Elival da Silva. Controle de Constitucionalidade no Brasil: perspectivas e evolução. São Paulo: Saraiva, 2010, p. 77 e 78.

${ }^{360}$ RAMOS, Elival da Silva. A Evolução do Sistema Brasileiro de Controle de Constitucionalidade e a Constituição de 1988, in RAMOS, Elival da Silva; MORAIS, Carlos Blanco de (Coord.). Perspectivas de Reformas da Justiça Constitucional em Portugal e no Brasil. Coimbra: Almedina, 2012, p. 70.

${ }^{361}$ Idem, p. 73 e 74.

${ }^{362}$ Bruno Dantas ressalta o reconhecimento dessa tendência nos RE 388.730/RJ, AgRg no RE 475.812/SP e no AgRg na Sentença Estrangeira 5.206. DANTAS, Bruno. Repercussão Geral: perspectiva histórica, dogmática e de direito comparado; questões processuais. São Paulo: Revista dos Tribunais, 2009, p. 73.

${ }^{363}$ DANTAS, Bruno. Repercussão Geral: perspectiva histórica, dogmática e de direito comparado; questões processuais. São Paulo: Revista dos Tribunais, 2009, p. 216.
} 
tanto em Estados unitários quanto federais, da imprescindibilidade de um tribunal de cúpula responsável pela manutenção da integridade do direito e da uniformização da sua interpretação. Segundo Bruno Dantas, "é difícil conceber, hoje em dia, algum país que não tenha adotado medidas para estabelecer filtros ao acesso de recursos a elas dirigidos". ${ }^{364}$

Elival da Silva Ramos questiona se a ideia de súmula jurisprudencial de caráter normativo se ajusta ao nosso sistema da família do civil law e se as consequências trazidas pelo instituto serão efetivamente benéficas ao sistema, tendo em vista que se correria o risco da diminuição dos recursos extraordinários ao custo do "aumento vertiginoso da quantidade de reclamações, de protocolização direta no âmbito da Suprema Corte", ${ }^{365}$

A repercussão geral, além de representar essa mudança no controle de constitucionalidade incidental, por objetivar as ações, tornando-as menos relacionadas às partes, também representa um tipo de raciocínio consequencialista, por condicionar a admissão de um recurso à utilidade que ele possa apresentar ao ordenamento jurídico, seja como precedente, seja pela relevância da causa em si.

$\mathrm{O}$ artigo que trata do assunto no Código de Processo Civil - 543-A, $\S 1^{\mathrm{o}}-$ afirma que: "Para efeito da repercussão geral, será considerada a existência, ou não, de questões relevantes do ponto de vista econômico, político, social ou jurídico, que ultrapassem os interesses subjetivos da causa". 366

É de fácil observação que o pressuposto específico de cabimento do recurso extraordinário torna o acesso à justiça mais dificultoso, e o faz para suprimir a demanda dos tribunais. Para um recurso ser aceito deve apresentar questões relevantes; do ponto de vista tradicional, deontológico, é uma matéria meramente hermenêutica, no sentido de que o juiz apenas deve interpretar os conceitos jurídicos indeterminados da relevância econômica, social etc. Mas na perspectiva apresentada até agora no trabalho é possível também analisar o fenômeno sob a lente consequencialista, pois o juiz prevê a relevância do caso como um futuro precedente, ou como algo com valor suficiente para movimentar a máquina judiciária, que tem custos para julgar um processo.

O observado no contexto do controle incidental é uma tendência a tornar esses processos menos ligados aos casos concretos, portanto, menos subjetivos às partes, embora

\footnotetext{
${ }^{364}$ Idem, p. 90 e 91.

${ }^{365}$ RAMOS, Elival da Silva. A Evolução do Sistema Brasileiro de Controle de Constitucionalidade e a Constituição de 1988, in RAMOS, Elival da Silva; MORAIS, Carlos Blanco de (Coord.). Perspectivas de Reformas da Justiça Constitucional em Portugal e no Brasil. Coimbra: Almedina, 2012, p. 83 e 84.

${ }^{366}$ BRASIL. Lei de $\mathrm{n}^{\circ}$ 5.869/73.
} 
Cianci e Almeida defendam uma inconstitucionalidade nessa tendência, por ferir o devido processo legal e gerar um sincretismo entre os sistemas difuso e concentrado. ${ }^{367}$

Argumentar-se-á no tópico 2.3 que o controle principal também está em modificação no Brasil, especialmente a possibilidade de controle de "leis de efeitos concretos" em ações que antes exigiam generalidade e abstração das suas matérias.

Observadas as principais características do controle de constitucionalidade brasileiro, no próximo tópico será dada uma atenção especial aos efeitos das decisões, especialmente no controle principal de constitucionalidade, foco da tese.

\subsection{Eficácia das decisões do Supremo Tribunal Federal e modulação de efeitos no controle principal}

Eficácia é um conceito jurídico ligado a outros institutos correlatos, à validade e à vigência. ${ }^{368}$ Começa-se pelos demais para entender o que é a eficácia.

A validade é uma relação de pertinência ao sistema. Isto é, uma norma é válida se não há ofensa a nenhuma outra hierarquicamente superior, seja pelo cumprimento de todos os procedimentos formais para a sua introdução no sistema, seja pela matéria que veicula. Por isso, "cumprido o processo de formação ou produção normativa, em conformidade com os requisitos do próprio ordenamento", tem-se uma norma válida. ${ }^{369}$

Tércio Sampaio Ferraz Jr. explicita algumas questões concernentes à validade:

O problema dogmático da validade é, assim, a questão de saber quando uma norma é reconhecida como válida para o ordenamento, a partir de que momento, quando deixa de valer, quais os efeitos que produz e quando e até quando os produz, se os produz mesmo quando não pode ser tecnicamente reconhecida como válida. ${ }^{370}$

367 CIANCI, Mirna; ALMEIDA, Gregório A. de. Direito Processual do Controle de Constitucionalidade. São Paulo: Saraiva, 2011, p. 61.

${ }^{368}$ Há ainda autores como Pontes de Miranda que falam no plano da existência, mas para Kelsen a validade da norma está ligada necessariamente à existência. Neste trabalho, validade e existência serão tidas como conceitos semelhantes.

${ }^{369}$ FERRAZ JR., Tércio. Introdução ao Estudo do Direito: técnica, decisão e dominação. $3^{\text {a }}$ ed. São Paulo: Atlas, 2001, p. 193.

${ }^{370}$ Idem, Ibdem. 
Vigência, por outro lado, é o período de produção de efeitos de uma norma. Nas palavras do Prof. Tércio Ferraz Jr., "termo com o qual se demarca o tempo de validade de uma norma". ${ }^{371}$ As normas vigentes são aquelas aptas a produzir efeitos para os fatos que ocorrem naquele determinado período. A diferença entre vigência e validade é relevante, inclusive do ponto de vista orçamentário. A Lei que dispõe o orçamento no Brasil em 2015 deixará de ser vigente em 2016, mas não deixará de ser válida por isso. Assim, mesmo uma norma inválida pode produzir efeitos até que venha a ser declarada a sua invalidade.

Ao mesmo tempo, "uma norma válida pode já ser vigente e, no entanto, não ter eficácia". ${ }^{372}$ A eficácia jurídica diz respeito não à validade, mas aos efeitos jurídicos produzidos por determinada norma. ${ }^{373}$

"A capacidade de produzir efeitos depende de certos requisitos. Alguns de natureza fática; outros, de natureza técnico-normativa". ${ }^{374}$ Quando se fala de eficácia, dois conceitos podem ser pensados.

O primeiro é o de eficácia social, ou efetividade, quando a produção de efeitos depende de circunstâncias fáticas para a sua realização. Nesse sentido, Tércio distingue ainda a eficácia social da observância da norma, que seria a especulação se a norma é cumprida efetivamente, mesmo preenchidas as circunstâncias fáticas relevantes para o caso. $^{375}$

O tema da eficácia das decisões judiciais está intimamente relacionado ao do consequencialismo jurídico. Prever as consequências, de modo amplo, das decisões judiciais, é pensar sobre os efeitos que elas podem produzir no campo social, econômico ou jurídico.

O segundo conceito que pode ser pensado é de que a eficácia jurídica das normas restringe-se aos efeitos estritamente jurídicos que produzem, como a criação de direitos, extinção de obrigações, autorização de condutas ou a proibição delas.

As decisões judiciais são veículos introdutores de normas jurídicas, que, assim como as normas legais, produzem efeitos jurídicos. Alguns dos principais aspectos do controle de constitucionalidade brasileiros estão relacionados à produção de efeitos, como

\footnotetext{
${ }^{371}$ Idem, p. 193 e 194.

${ }^{372}$ Idem, p. 194.

${ }^{373}$ Sobre o assunto, ver BOBBIO, Norberto. Teoria da Norma Jurídica. $2^{\text {a }}$ ed. Bauru: Edipro, 2003, p. 48 e ss.

${ }^{374}$ FERRAZ JR., Tércio. Introdução ao Estudo do Direito: técnica, decisão e dominação. $3^{a}$ ed. São Paulo: Atlas, 2001, p. 194 e 195.

375 Idem, p. 195.
} 
a fixação dos destinatários da decisão judicial, ou seja, se a decisão produz efeitos erga omnes ou inter partes.

Os sistemas de controle concentrado, ou no Brasil, o controle principal, normalmente produzem efeitos a um público não identificável, logo, geral e não individual. A distinção entre efeitos erga omnes ou inter partes, portanto, emerge das mesmas premissas da citada distinção de Bobbio entre normas gerais e individuais. Normas gerais produzem efeitos erga omnes, e normas individuais, inter partes.

No entanto, os efeitos produzidos pelas decisões judiciais vão além dessa simples distinção. Como visto no terceiro capítulo da primeira parte, as decisões, mesmo as que em tese produzem efeitos inter partes, devem pensar nas consequências jurídicas das suas disposições no ordenamento jurídico. Nesse sentido, para Luiz Alberto David Araújo e Vidal Serrano Nunes Júnior, a finalidade do processo no controle concentrado é "resguardar a harmonia do ordenamento jurídico, motivo pelo qual se pode afirmar que o controle concentrado tem por finalidade declarar a nulidade da lei violadora da Constituição". 376

Outro aspecto da produção de efeitos no controle de constitucionalidade diz respeito à sua irretroatividade no tempo. Os modelos austríaco e estadunidense ofereciam respostas diferentes à questão da irretroatividade da decisão da inconstitucionalidade. Enquanto no modelo austríaco a questão se resolvia a partir da decisão, chamado de efeito ex nunc, no modelo estadunidense a decisão era vista como meramente declaratória e estipulativa de um efeito retroativo, ex tunc.

Fábio Martins de Andrade elaborou quadro comparativo interessante sobre os dois modelos, que aqui segue parcialmente: ${ }^{377}$

\begin{tabular}{|c|c|c|}
\hline Sistema de origem & Norte-americano & Austríaco \\
\hline Efeito da inconstitucionalidade & Nulidade & Anulabilidade \\
\hline Sistema de controle & Difuso & Concentrado \\
\hline Natureza da decisão & Declaratória & (Des)constitutiva negativa \\
\hline Efeitos no tempo & Ex tunc & Ex nunc \\
\hline Planos dos atos jurídicos & Validade & Eficácia \\
\hline
\end{tabular}

${ }^{376}$ ARAÚJO, Luiz Alberto D. de; SERRANO JÚNIOR, Vidal. Curso de Direito Constitucional. São Paulo: Saraiva, 2010, p. 58.

377 ANDRADE, Fábio Martins. Modulação em Matéria Tributária: o argumento pragmático ou consequencialista de cunho econômico e as decisões do STF. São Paulo: Quartier Latin, 2011, p. 260. 
A tabela é simples, mas opõe bem as principais características dos dois sistemas, embora muitas vezes os sistemas contemporâneos possam apresentar características diversas e mescladas.

A discussão ganha corpo no Brasil em razão do instituto da modulação dos efeitos das decisões no controle de constitucionalidade.

A técnica de modulação de efeitos é uma das expressões mais claras do consequencialismo jurídico positivadas no direito brasileiro. Parte-se do pressuposto de que o consequencialismo não é contrário ao positivismo jurídico, ou seja, que normas podem prever raciocínios consequencialistas, de forma que isso não retiraria tal natureza.

A discussão da modulação e do consequencialismo jurídico de forma geral remonta ao primeiro capítulo, no tema ativismo judicial. A possibilidade de modular os efeitos das decisões dá ao Judiciário maior liberdade para determinar o controle de constitucionalidade das normas e de determinar a produção de efeitos por uma norma declaradamente inconstitucional. André Ramos Tavares afirma que para muitos autores a modulação de efeitos "aproxima-se de uma atividade meramente legislativa, por basear-se em critérios de conveniência e oportunidade do Tribunal Constitucional". ${ }^{378}$ É a discussão de que por inúmeras vezes o próprio Supremo Tribunal Federal age em self-restraint quando julga que certa medida seria típica do legislador positivo, enquanto apenas lhe caberia o papel de legislador negativo. O sistema de modulação de efeitos, para Lenio Streck, ganha força em razão da insuficiência do modelo de nulidade em face do perfil atual do Estado, no contexto de uma Constituição dirigente, exigindo do Estado não apenas abstenções, mas também prestações positivas. ${ }^{379}$

$\mathrm{Na}$ verdade, modulações de efeitos podem ser de vários tipos. Segundo Rothenburg,

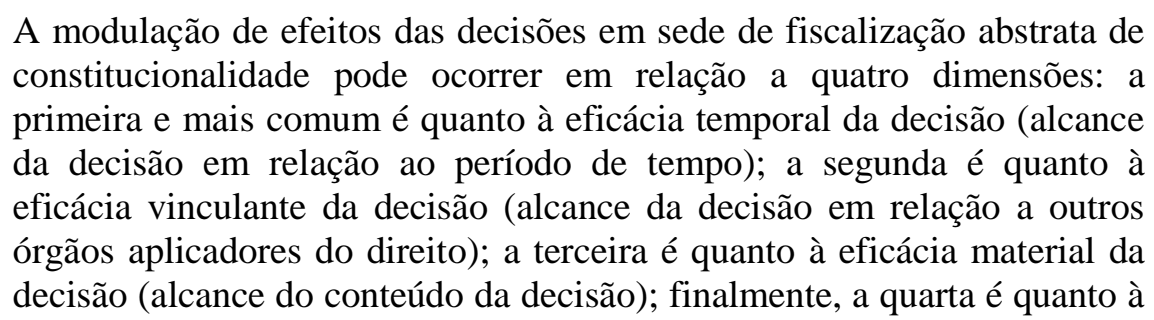

\footnotetext{
${ }^{378}$ TAVARES, André Ramos. Paradigmas do Judicialismo Constitucional. São Paulo: Saraiva, 2012, p. 49.

${ }^{379}$ STRECK, Lenio Luiz. Jurisdição Constitucional e Decisão Jurídica. $3^{a}$ ed. São Paulo: Revista dos Tribunais, 2013, p. 808.
} 
eficácia subjetiva da decisão (alcance da decisão em relação ao universo de pessoas afetadas). ${ }^{380}$

Há, portanto, outros tipos de modulação, além da temporal, mais citada e comum, e que "cuida do alcance da decisão em relação ao período de tempo em que atua ou deixa de atuar". 381

Na modulação do tipo temporal, que será o foco deste tópico, há quatro tipos de efeitos possíveis que as decisões judiciais podem prescrever. Em primeiro lugar, o efeito ex tunc, regra geral do controle de constitucionalidade do direito brasileiro, no qual as decisões retroagiriam, se é que isso é possível, ou, melhor dizendo, fixariam no momento da positivação da lei o início da produção de efeitos da inconstitucionalidade. $\mathrm{O}$ segundo padrão de produção de efeitos seria o ex nunc, regra geral no sistema de controle de constitucionalidade austríaco descrito por Kelsen, em que os efeitos da inconstitucionalidade seriam produzidos a partir da decisão, sem, portanto, retroagir para o momento da produção normativa. Uma terceira possibilidade seria a produção de efeitos retroativos, não ao momento da produção normativa, mas até outro ponto fixado arbitrariamente pelo Judiciário quando da decisão. Este efeito pode ser chamado de ex tunc com restrições. E, por fim, a eficácia pro futuro, que fixa momento posterior ao da decisão para o início da produção de efeitos da inconstitucionalidade. ${ }^{382}$

André Ramos Tavares afirma que o uso da modulação temporal pode comprometer a supremacia da Constituição por permitir que o Tribunal Constitucional a altere, mesmo que restrito no tempo. ${ }^{383}$ Muito embora no sistema de controle de constitucionalidade austríaco, nos tempos de Kelsen, a regra fosse a produção de efeitos a partir da decisão, todos esses efeitos pretendem dirimir os constantes conflitos entre a segurança jurídica e a supremacia da Constituição, valores essenciais do ordenamento. Isto é, em defesa da produção de efeitos de normas declaradamente inconstitucionais, busca-se proteger a segurança jurídica quando os resultados são indesejáveis ou catastróficos.

A Constituição portuguesa, diferentemente da brasileira que o fez por lei ordinária, prevê expressamente a possibilidade de modulação de efeitos no artigo 282, que

380 ROTHENBURG, Walter Claudius. Velhos e Novos Rumos das Ações de Controle Abstrato de Constitucionalidade à Luz da Lei no 9.868/99, in SARMENTO, Daniel (Org.). O Controle de Constitucionalidade e a Lei 9.868/99. Rio de Janeiro: Lumen Iuris, 2002, p. 283.

381 ANDRADE, Fábio Martins. Modulação em Matéria Tributária: o argumento pragmático ou consequencialista de cunho econômico e as decisões do STF. São Paulo: Quartier Latin, 2011, p. 337.

${ }^{382}$ Idem, Ibidem.

383 TAVARES, André Ramos. Paradigmas do Judicialismo Constitucional. São Paulo: Saraiva, 2012, p. 53. 
possui a seguinte redação: "quando a segurança jurídica, razões de equidade ou interesse público de excepcional relevo, que deverá ser fundamentado, o exigirem, poderá o Tribunal Constitucional fixar os efeitos da inconstitucionalidade ou da ilegalidade com alcance mais restrito". ${ }^{384}$

Sobre os efeitos pro futuro na modulação de efeitos, Canotilho afirma que não seriam claros em uma decisão dessa natureza, pois:

\begin{abstract}
Por um lado, a norma continua a vigorar; por outro lado, a declaração de incompatibilidade pretende constituir uma "barreira" ou "proibição" de aplicação dirigida aos tribunais e entidades administrativas. Relativamente ao legislador, a "sobrevivência de norma" significa apenas que ele deve criar uma disciplina jurídica constitucional num prazo adequado ("dever de aperfeiçoamento da lei"). ${ }^{385}$
\end{abstract}

No sistema brasileiro não só é admitida a eficácia pro futuro como o Supremo Tribunal Federal já adotou a técnica modulativa para determinar o efeito futuro de uma decisão justamente num caso de norma do direito financeiro, especificamente a que trata do repasse de receitas da União aos estados por meio do Fundo de Participação dos Estados - FPE. Neste caso, ADI 875/DF, o Tribunal decidiu em 2010 que apenas após dois anos os critérios declarados inconstitucionais deixariam de ser usados, dispondo a necessidade de produção de um novo sistema de critérios para distribuição da receita. Isso só veio a ocorrer no ano de 2013, quando prorrogada ainda mais a ultratividade dos critérios inconstitucionais diante da não promulgação a tempo de novos critérios pelo Legislativo. Fato curioso é que a lei nova, Lei Complementar 143, de 17 de julho de 2013, fixou até 31 de dezembro de 2015 a aplicação dos atuais critérios declarados inconstitucionais, de forma que os novos critérios, adequados ao texto constitucional, apenas serão aplicados em 2016, quase seis anos após a declaração de inconstitucionalidade.

Daniel Sarmento critica a eficácia pro futuro ilimitada, como posto pela Lei 9.868/99 no Brasil. Pela interpretação literal do dispositivo, segundo ele, o STF estaria autorizado a manter norma inconstitucional por dez ou vinte anos. Observa que diante da razoabilidade e da proporcionalidade, e tendo em vista que a modulação de efeitos pretende mitigar o "horror aos vazios normativos", dando ao Legislativo a oportunidade de

\footnotetext{
384 PORTUGAL. Constituição da República Portuguesa. Disponível em: <http://www.parlamento.pt/Legislacao/Paginas/ConstituicaoRepublicaPortuguesa.aspx>. Acesso em 12.11.2013.

385 CAnotilho, J. J. Gomes. Direito Constitucional e Teoria da Constituição. $7^{\mathrm{a}}$ ed. Coimbra: Almedina, 2003, p. 958.
} 
legislar sobre a matéria e cobrir tal vazio, "nada justifica que se retarde por mais de seis meses os efeitos da decisão no controle de constitucionalidade". 386

Vê-se que a discussão sobre modulação de efeitos é atual e importante para o controle de constitucionalidade no Brasil. Mas no sistema constitucional austríaco descrito por Hans Kelsen já se podem observar traços ou mesmo uma modulação de efeitos embrionária da hoje exercida pelo Supremo Tribunal Federal brasileiro.

Afirma Kelsen que em princípio as decisões da Corte Constitucional possuíam efeito ex nunc, ou seja, a partir da decisão, e não retroativa. Porém, excepcionalmente e não por período superior a um ano, a Corte poderia estabelecer um adiamento dos efeitos da sua decisão, prazo que serviria para que a legislatura pudesse substituir a lei impugnada por outra nova e constitucional. ${ }^{387}$

Sobre a modulação de efeitos nos sistemas europeus, afirma Elival da Silva Ramos:

\begin{abstract}
Mas a característica mais notável dos sistemas europeus hodiernos, em relação aos efeitos temporais das decisões de controle, é a competência dos Tribunais Constitucionais para a modulação desses efeitos, do que resulta a possibilidade de anulações acentuadamente retroativas, que, reportando-se ao nascimento do ato impugnado, buscam eliminar a maior parte dos seus efeitos pretéritos; anulações limitadamente retroativas, que invalidam o ato legislativo a partir de um marco temporal situado no passado, porém posterior à sua entrada em vigor; anulações irretroativas ou ex nunc; e, finalmente, anulações diferidas pro futuro. ${ }^{388}$
\end{abstract}

No Brasil a modulação foi prevista no artigo 27 da lei 9.868/1999, que trata do processo e julgamento da ação direta de inconstitucionalidade e da ação declaratória de constitucionalidade perante o Supremo Tribunal Federal, e dispõe:

Art. 27. Ao declarar a inconstitucionalidade de lei ou ato normativo, e tendo em vista razões de segurança jurídica ou de excepcional interesse social, poderá o Supremo Tribunal Federal, por maioria de dois terços de seus membros, restringir os efeitos daquela declaração ou decidir que ela só tenha eficácia a partir de seu trânsito em julgado ou de outro momento que venha a ser fixado. ${ }^{389}$

386 SARMENTO, Daniel. A Eficácia Temporal das Decisões no Controle de Constitucionalidade, in SARMENTO, Daniel (Org.). O Controle de Constitucionalidade e a Lei 9.868/99. Rio de Janeiro: Lumen Iuris, 2002, p. 128.

${ }^{387}$ KELSEN, Hans. O Controle Judicial da Constitucionalidade: um estudo comparado das Constituições austríaca e americana, in Jurisdição Constitucional. São Paulo: Martins Fontes, 2007, p. 305.

${ }^{388}$ RAMOS, Elival da Silva. Controle de Constitucionalidade no Brasil: perspectivas e evolução. São Paulo: Saraiva, 2010, p. 90.

${ }^{389}$ O artigo 11 da Lei 9.882/1999, que trata das Arguições de Descumprimento de Preceitos Fundamentais, traz basicamente a mesma previsão e redação. "Art. 11. Ao declarar a inconstitucionalidade de lei ou ato 
A interpretação dada pelo Supremo Tribunal Federal ao artigo é a mais ampla possível, pois a modulação foi aplicada inclusive ao controle incidental, ${ }^{390}$ mesmo os artigos sendo originalmente desenhados para o controle principal, em ADIs, ADCs e ADPFs. Lenio Streck chama de equivocada a tendência do STF a equiparar o controle concentrado ao difuso, especialmente a possibilidade de modular efeitos nas decisões que declaram a inconstitucionalidade em sede de controle difuso. ${ }^{391}$

As expressões de maior abertura semântica, "segurança jurídica" e "excepcional interesse social", ainda carecem de melhores parâmetros, que deverão ser construídos pela própria jurisprudência da Corte.

Com relação ao primeiro conceito, de segurança jurídica, Fábio Martins de Andrade destaca a ideia de previsibilidade, e que, apesar da indeterminação do conceito, alguns limites podem ser traçados, como o dever de modulação no caso de mudança de entendimento jurisprudencial, atribuindo a decisão ao menos a eficácia ex nunc, se não a pro futuro.

Faz todo sentido. Se o Tribunal, pois, entendia que uma norma $\mathrm{X}$ seria constitucional, e os cidadãos passavam a agir conforme aquela decisão, no caso de uma mudança de entendimento, o efeito ex tunc não seria recomendado em proteção ao princípio da segurança jurídica. Isso também estaria de acordo com a ideia de universalidade proposta por Neil MacCormick e exposta anteriormente, e com a própria ideia de consequencialismo defendida neste trabalho.

A segunda expressão, ainda mais do que a primeira, parece revelar uma norma de cunho consequencialista. Modular os efeitos em caso de "excepcional interesse social" abre ao Judiciário amplas possibilidades de decisão, e. embora o argumento deontológico fundamente a possibilidade de modulação, todas as decisões em torno da aplicação da modulação serão conduzidas por argumentos consequencialistas.

Uma vez compreendidos os aspectos fundamentais do controle principal de constitucionalidade no Brasil, no próximo tópico serão vistos os instrumentos processuais que possibilitam tal controle, mais uma vez, não em todos os seus aspectos, mas naquilo

normativo, no processo de argüição de descumprimento de preceito fundamental, e tendo em vista razões de segurança jurídica ou de excepcional interesse social, poderá o Supremo Tribunal Federal, por maioria de dois terços de seus membros, restringir os efeitos daquela declaração ou decidir que ela só tenha eficácia a partir de seu trânsito em julgado ou de outro momento que venha a ser fixado".

${ }^{390}$ Conforme pode se compreender no julgamento do Recurso Extraordinário n ${ }^{\circ} 357.657$.

391 STRECK, Lenio Luiz. Jurisdição Constitucional e Decisão Jurídica. $3^{\text {a }}$ ed. São Paulo: Revista dos Tribunais, 2013, p. 527. 
que é fundamental para entender o controle de constitucionalidade de normas e leis orçamentárias.

\subsection{Instrumentos processuais do controle de constitucionalidade principal das leis e} normas orçamentárias no Brasil

\subsubsection{ADI, ADC e ADO: o controle de constitucionalidade de leis e atos normativos}

Além da Arguição de Descumprimento de Preceito Fundamental, que será objeto de estudo no próximo tópico, há no direito brasileiro três instrumentos muito parecidos no controle de constitucionalidade principal.

São eles: i) a Ação Direta de Inconstitucionalidade - ADI; ii) a Ação Declaratória de Constitucionalidade - ADC (ou ADECON); e iii) a Ação Direta de Inconstitucionalidade por Omissão - ADO.

Tais ações, como é característico do controle principal, não pretendem questionar a constitucionalidade das leis para atender a interesses subjetivos, mas simplesmente proteger o ordenamento jurídico constitucional em situações objetivas.

Uma propriedade importante na história do controle de constitucionalidade principal no Brasil realizado por tais instrumentos é o de não conhecer ações que tenham por objeto o questionamento de normas cuja generalidade e abstração não sejam características.

Gilmar Mendes, em livro sobre o tema, afirma que: “A jurisprudência do Supremo Tribunal Federal tem considerado inadmissível a propositura de ação direta de inconstitucionalidade contra atos de efeito concreto". ${ }^{392}$ Isso afeta diretamente o controle de normas orçamentárias, que dispostas em "leis de efeitos concretos", ficam sem a tutela estatal, num verdadeiro (des)controle de constitucionalidade. No mesmo sentido, José Levi do Amaral Júnior afirma que:

A jurisprudência tradicional do Supremo Tribunal Federal era refratária à análise de ações diretas contra a legislação orçamentária, ao entendimento de que não caberia controle concentrado contra leis (apenas) formais, ou seja, destituídas de generalidade e abstração (caso da

392 MENDES, Gilmar Ferreira \& MARTINS, Ives Gandra da S. Controle Concentrado de Constitucionalidade: comentários à Lei n. 9.868, de 10-11-1999. $3^{\text {a }}$ ed. São Paulo: Saraiva, 2009, p. 193. 
legislação orçamentária, no que relativa a rubrica de gastos, que são evidentemente - normas individuais e concretas. ${ }^{393}$

Sendo um dos limites tradicionais do controle de constitucionalidade a exigência da generalidade e abstração das normas jurídicas, o estudo do controle das leis orçamentárias tem interesse especial ao direito financeiro, mas a ele transborda, importando na própria ideia de controle dos atos do Estado. Serve de paradigma para vários outros tipos de controle de constitucionalidade.

A discussão sobre a generalidade e abstração das normas que sofrem controle de constitucionalidade possui duas instâncias. A primeira, em relação ao texto constitucional e infraconstitucional da lei que regulou a matéria com igual teor. A segunda, quanto à jurisprudência do Supremo Tribunal Federal sobre o assunto.

A suposta impossibilidade de controle de leis de efeitos concretos nasce da expressão utilizada pela Constituição Federal - "lei ou ato normativo". A expressão era encontrada em três passagens da Carta.

A primeira, no artigo 97, onde se afirma que "Somente pelo voto da maioria absoluta de seus membros ou dos membros do respectivo órgão especial poderão os tribunais declarar a inconstitucionalidade de lei ou ato normativo do Poder Público".

A segunda, no artigo 102, I, a, que menciona duas vezes a expressão, e que é o objeto da polêmica deste tópico.

Art. 102. Compete ao Supremo Tribunal Federal, precipuamente, a guarda da Constituição, cabendo-lhe:

I - processar e julgar, originariamente:

a) a ação direta de inconstitucionalidade de lei ou ato normativo federal ou estadual e a ação declaratória de constitucionalidade de lei ou ato normativo federal.

A última passagem, introduzida pela Emenda $n^{\circ} 3$, de 1993, teve sua redação alterada pela Emenda Constitucional n ${ }^{\circ} 45$, de 2004. Dizia a redação antiga do parágrafo $2^{\circ}$ do artigo 102:

$\S 2^{\circ}$ As decisões definitivas de mérito, proferidas pelo Supremo Tribunal Federal, nas ações declaratórias de constitucionalidade de lei ou ato normativo federal, produzirão eficácia contra todos e efeito vinculante, relativamente aos demais órgãos do Poder Judiciário e ao Poder Executivo.

393 AMARAL JÚNIOR, José Levi M. do. Medida Provisória: edição e conversão em lei. São Paulo: Saraiva, 2012, p. 127. 
A nova redação assim dispõe:

$\S 2^{\circ}$ As decisões definitivas de mérito, proferidas pelo Supremo Tribunal Federal, nas ações diretas de inconstitucionalidade e nas ações declaratórias de constitucionalidade, produzirão eficácia contra todos e efeito vinculante, relativamente aos demais órgãos do Poder Judiciário e à administração pública direta e indireta, nas esferas federal, estadual e municipal.

Uma das mudanças visíveis é a retirada da expressão "lei ou ato normativo federal", não mais existente nesse dispositivo após a Emenda Constitucional nº 45/2004.

Na Lei no 9.868/1999 repetiu-se a expressão cunhada pela Constituição Federal com a seguinte redação: “Art. 14. A petição inicial indicará: I - o dispositivo da lei ou do ato normativo questionado e os fundamentos jurídicos do pedido".

Mas o que essa expressão afinal quer dizer? Qual o seu papel no controle de constitucionalidade?

Para entender o assunto por completo é fundamental conhecer a segunda e última instância da discussão, que é a jurisprudência do Supremo Tribunal Federal sobre a matéria, isto é, o precedente estabelecido na Corte acerca da admissibilidade do controle de constitucionalidade de leis com base na expressão citada.

Para o Supremo Tribunal Federal, ao menos, esse era o precedente quando a Constituição definiu a competência da Ação Direta de Inconstitucionalidade e da Ação Declaratória de Constitucionalidade de "lei ou ato normativo". Seria restrita ao controle tanto de atos infralegais quanto de leis que apresentassem natureza normativa, que em última instância consistiria na apresentação das características da generalidade e abstração das normas pelo ato ou lei veiculadas. O precedente era o de rechaçar o controle de constitucionalidade de leis meramente formais, que não possuíssem conteúdo normativo, segundo seu próprio entendimento.

Celso de Barros Correia Neto ressalva que em muitas decisões, especialmente as que tratam de matéria orçamentária, o Supremo não deixa claro qual o conteúdo jurídico das expressões "lei formal" ou de "atos de efeito concreto", utilizadas para evitar o controle de constitucionalidade de certos atos normativos. Afirma o autor que:

Por se tratar de lei formal, isto é, lei de efeitos meramente concretos, faltariam às leis orçamentárias os requisitos da generalidade e abstração eleitos como condições fundamentais para a viabilidade do controle de 
constitucionalidade abstrato, especialmente por ação direta de inconstitucionalidade. ${ }^{394}$

Na verdade, o Supremo Tribunal Federal, embora não claramente, como apontado, trabalha com a classificação exposta por Norberto Bobbio entre normas gerais ou individuais, abstratas ou concretas, apresentada no capítulo anterior (Item 1.3). Ou seja, norma abstrata é a que tem possibilidade de múltiplas incidências; assim, numa norma concreta, a incidência desta se esgota parcialmente ou totalmente. Uma norma abstrata, ao contrário, não se esgota de nenhuma maneira.

Régis Fernandes de Oliveira, com precisão, define a abstração de uma norma jurídica como a "repetição, sem exaurimento da previsão legal, da denominada açãotipo". 395

Por exemplo, quando a lei orçamentária anual federal dispõe a criação de créditos adicionais, tem-se uma norma abstrata, pois todas as vezes que surgir a necessidade de criação de um crédito adicional, a norma incidirá sobre o caso. Por outro lado, as normas que dispõem, na mesma lei orçamentária, despesas por meio de uma dotação, são concretas, pois uma vez executada toda a despesa autorizada, a norma realiza completamente seus objetivos e sua eficácia se dá por completo.

Gilmar Mendes ressalta que o constituinte não fez distinção entre as leis dotadas de generalidade e as conformadas sem o atributo da generalidade e abstração. Essas leis, nas quais se incluem as orçamentárias, decorrem da vontade de que determinados atos, ainda que de efeito concreto, sejam editados sob a forma de lei, submetendo-se ao mesmo regime de controle. ${ }^{396}$ E aduz:

Ressalte-se que não se vislumbram razões de índole lógica ou jurídica contra a aferição da legitimidade das leis formais no controle abstrato de normas, até porque abstrato - isto é, não vinculado ao caso concreto - há de ser o processo, e não o ato legislativo submetido ao controle de constitucionalidade. $^{397}$

O Ministro Gilmar Mendes, na obra "Controle Abstrato de Constitucionalidade: ADI, ADC e ADO”, defende o seguinte:

${ }^{394}$ CORREIA NETO, Celso de Barros. O Orçamento Público e o Supremo Tribunal Federal, in CONTI, José Maurício \& SCAFF, Fernando Facury (Coord.). Orçamentos Públicos e Direito Financeiro. São Paulo: Editora Revista dos Tribunais, 2011.

${ }^{395}$ OLIVEIRA, Régis Fernandes. Curso de Direito Financeiro. $5^{\mathrm{a}}$ ed. São Paulo: RT, 2013, p. 406.

${ }^{396}$ MENDES, Gilmar Ferreira. Controle Abstrato de Constitucionalidade: ADI, ADC e ADO. São Paulo: Saraiva, 2012, p. 137.

397 Idem, p. 138. 
A extensão dessa jurisprudência, desenvolvida para afastar do controle abstrato de normas os atos administrativos de efeito concreto, chamadas leis formais, suscita, sem dúvida, alguma insegurança, porque coloca a salvo do controle de constitucionalidade um sem-número de leis.

(...)

Outra há de ser, todavia, a interpretação, se se cuida de atos editados sob a forma de lei. Nesse caso, houve por bem o constituinte não distinguir entre leis dotadas de generalidade e aqueloutras, conformadas sem o atributo da generalidade e abstração.

(...)

não me parece admissível que o intérprete debilite essa garantia da Constituição, isentando um número elevado de atos aprovados sob a forma de lei do controle abstrato de normas e, muito provavelmente, de qualquer forma de controle. ${ }^{398}$

A evolução jurisprudencial das decisões tomadas em controle principal pelo Supremo Tribunal Federal na aferição de constitucionalidade de normas orçamentárias é central na tese, representativa não apenas do direito financeiro em si, mas de todo o controle realizado no Brasil.

Em sentido contrário, Paulo Dantas afirma:

Devemos entender por lei, no caso específico da ação direta de inconstitucionalidade genérica, os preceitos escritos, emanados do poder competente da União, dos Estados, e, em alguns casos, do Distrito Federal, dotados de imperatividade e coerção estatal, e que, para fins de controle de constitucionalidade, devem ter por características a abstração, a generalidade e a autonomia. ${ }^{399}$

E conclui o autor que seria o caso de não sujeição às ADIs "diversos atos normativos de efeitos concretos e individuais". Oferece como meio adequado para tais atos a ação popular ou o mandado de segurança. ${ }^{400}$

Juliano Taveira Bernardes, em livro publicado em 2004, afirma que "segundo o STF, leis de conteúdo concreto ou de destinatário predeterminado ou predeterminável não se submetem ao controle abstrato pela via das ações diretas, por impossibilidade jurídica do pedido". ${ }^{401}$ Mas argumenta que "no caso de inexistir risco de conflito entre jurisdições

\footnotetext{
${ }^{398}$ Idem, p. 137.

${ }^{399}$ DANTAS, Paulo R. de F. Direito Processual Constitucional. $3^{\text {a }}$ ed. São Paulo: Atlas, 2012, p. 230.

${ }^{400}$ Idem, p. 232. Cianci e Almeida, embora não enfrentem o tema com a profundidade exigida, defendem que a análise sobre abstração e generalidade apenas se dá para atos normativos e não colocam restrições às leis como objeto de averiguação por ADI. CIANCI, Mirna; ALMEIDA, Gregório A. de. Direito Processual do Controle de Constitucionalidade. São Paulo: Saraiva, 2011, p. 166.

${ }^{401}$ BERNARDES, Juliano T. Controle Abstrato de Constitucionalidade: elementos materiais e princípios processuais. São Paulo: Saraiva, 2004, p. 178.
} 
de controle concentrado (abstrato) e difuso (concreto), cai a razão por que se deva reduzir o espeque do controle, via de ações diretas, somente a leis em sentido material". ${ }^{402}$

Lenio Streck afirma que o modelo de "controle concentrado de constitucionalidade caracteriza-se pela apreciação de leis que contenham 'um caráter de generalidade"”. Mas zonas cinzentas existiriam, como a da ADI 2.925, que "demonstram uma vez mais a complexidade e a dificuldade em se traçar um limite entre a generalidade e os efeitos concretos exsurgentes de um determinado ato normativo". 403

Queiroz afirma que o conceito tradicional e apertado da lei como apenas norma geral e abstrata está ultrapassado. E conclui afirmando que: “A questão não é, pois, de generalidade (ou de abstracção) da norma, mas do respectivo posicionamento na hierarquia dos processos de produção jurídica". 404

Afastar as leis orçamentárias é equivocado mesmo do ponto de vista hermenêutico, por não corresponder a uma interpretação possível do texto constitucional, que em nenhum momento limita o conceito de lei para análise no controle de constitucionalidade, nem é adequado do ponto de vista consequencialista, pois o controle principal de leis orçamentárias é certamente o mais apropriado de acordo com as razões com as quais este capítulo será finalizado.

Não há no texto constitucional ou infraconstitucional, isto é, nas normas que regulam o funcionamento das ações do controle principal, referência alguma à limitação no que diz respeito às normas cujo objeto seja concreto e não abstrato. Quando, por exemplo, o artigo constitucional 102, I, $a$, refere a competência do Supremo Tribunal Federal para julgar por ADI e ADC de lei ou ato normativo, não se deve interpretar que normas concretas não seriam normativas, portanto, mesmo constantes em leis não sofreriam o controle principal. Por dois motivos: 1) a palavra normativa, embora o STF tenha entendido assim por um tempo, não se refere à lei, mas apenas à expressão “ato". Seria, de fato, redundante falar em lei normativa; 2) a palavra normativa também não significa restrição às normas jurídicas concretas, pois, de acordo com os maiores mestres do tema, Kelsen e Bobbio, normas concretas, ainda assim, são normas jurídicas, com força normativa, por assim dizer.

\footnotetext{
${ }^{402}$ Idem, p. 180.

403 STRECK, Lenio Luiz. Jurisdição Constitucional e Decisão Jurídica. $3^{\text {a }}$ ed. São Paulo: Revista dos Tribunais, 2013, p. 699 e 700.

${ }^{404}$ QUEIROZ, Cristina. Direito Constitucional: as instituições do Estado Democrático e Constitucional. Coimbra: Editora Coimbra, 2009, p. 303 e 304.
} 


\subsubsection{ADPF}

Elival Ramos critica de início a redação constitucional que dispõe a Arguição de Descumprimento de Preceito Fundamental - ADPF, por criar um instrumento de baixa densidade normativa, diante da importância da matéria para a proteção de direitos constitucionais fundamentais. ${ }^{405} \mathrm{O}$ texto, por exemplo, fala em "na forma da lei", limitando a eficácia da norma que foi finalmente regulada em 1999, mais de dez anos após a promulgação do texto constitucional.

Apesar de se chamar Arguição, segundo Paulo Dantas, trata-se de ação constitucional colocada no mesmo patamar da ADI e das demais espécies tratadas. ${ }^{406}$ Ele define a expressão "preceitos fundamentais" como:

Os princípios e regras da Constituição indispensáveis à caracterização e existência do ente estatal, notadamente as relativas aos seus princípios fundamentais, à sua estrutura, forma de Estado e de governo, regime político, modo de aquisição e exercício do poder, estabelecimento de seus órgãos e fixação de suas competências, cláusulas pétreas, além dos direitos e garantias fundamentais. ${ }^{407}$

A ADPF é uma ação subsidiária das demais ações constitucionais vistas no item anterior e tem como objetivo proteger não todas as normas constitucionais, mas aquelas que possam ser interpretadas como normas fundamentais do Estado, conforme a exposição acima de Paulo Dantas. Por isso Elival da Silva Ramos afirma que a ADPF foi um passo no sentido de fortalecer o controle em via principal, em detrimento do controle incidental, caracterizando uma "autêntica ação direta de inconstitucionalidade subsidiária, utilizável nas situações que restaram à margem do controle abstrato de normas". 408

A ADPF tem um objeto mais restrito que as demais ações constitucionais. Enquanto a ADI, por exemplo, se presta a proteger todo o conteúdo constitucional, a ADPF apenas pretende resguardar os preceitos fundamentais da Constituição.

Segundo Paulo Dantas, a ADPF não se limitaria às leis e atos normativos, como supostamente a ADI, tendo por objeto "não só as diversas espécies normativas, como

\footnotetext{
405 RAMOS, Elival da Silva. Arguição de Descumprimento de Preceito Fundamental: delineamento do instituto, in TAVARES, André Ramos; ROTHENBURG, Walter Claudius. Arguição de Descumprimento de Preceito Fundamental: análises à luz da Lei no 9.882/99. São Paulo: Atlas, 2001, 109 a 111.

${ }^{406}$ DANTAS, Paulo R. de F. Direito Processual Constitucional. 3a ed. São Paulo: Atlas, 2012, p. 268 e 269.

407 Idem, p. 271.

${ }^{408}$ RAMOS, Elival da Silva. A Evolução do Sistema Brasileiro de Controle de Constitucionalidade e a Constituição de 1988, in RAMOS, Elival da Silva; MORAIS, Carlos Blanco de (Coord.). Perspectivas de Reformas da Justiça Constitucional em Portugal e no Brasil. Coimbra: Almedina, 2012, p. 75.
} 
também todos os demais atos praticados pelo Poder Público, ou por quem lhe faça as vezes, no exercício de prerrogativas públicas, que tenham a potencialidade de violar preceitos fundamentais da Lei Maior". 409

Se algum tipo normativo, como a lei orçamentária, apenas pudesse ser confrontado perante a Constituição por meio da ADPF, as normas constitucionais que fossem contrariadas por tal lei orçamentária estariam desprotegidas. Isto é, desde que não fossem consideradas preceitos fundamentais, normas constitucionais poderiam ser contrariadas por atos normativos infraconstitucionais não passíveis de controle objetivo pelas demais ações.

\subsection{Controle de constitucionalidade de leis e normas orçamentárias}

O controle de constitucionalidade de leis orçamentárias é o ponto central deste trabalho, que analisará a jurisprudência do Supremo Tribunal Federal no capítulo que sucede imediatamente a este tópico. No entanto, cabem aqui algumas considerações sobre as disposições deontológicas, lógico-sistemáticas que concernem a esse controle no Brasil. Isto é, uma análise não da argumentação jurídica, mas do sistema normativo brasileiro sobre a matéria.

Talvez o ponto mais importante a ser explorado aqui seja o da necessidade ou importância do controle principal de constitucionalidade das leis orçamentárias.

O controle incidental objetiva tratar de casos nos quais há subjetividade, direitos feridos de alguém que tenha interesse processual. O controle principal, como se presta a tratar objetivamente as questões constitucionais, sem questionar o direito subjetivo de ninguém, é o mais adequado para cuidar de questões orçamentárias, que na realidade são, na maioria das vezes, transcendentais aos direitos individualizáveis.

Não é preciso, nem necessário, rechaçar o controle incidental sobre as leis orçamentárias, mas apenas reforçar que o controle principal, confrontando as normas orçamentárias diretamente com o texto constitucional, é essencial para proteger a Constituição como um todo diante de invalidades trazidas pelas leis do orçamento.

${ }^{409}$ DANTAS, Paulo R. de F. Direito Processual Constitucional. 3a ed. São Paulo: Atlas, 2012, p. 273. 
O controle incidental de constitucionalidade das normas orçamentárias ainda apresenta outra desvantagem. É que o princípio orçamentário da periodicidade impede que ações que tenham como objeto leis orçamentárias sejam efetivas:

Essa característica da periodicidade, condição de existência dos orçamentos, é também uma das maiores, senão a maior, razão para falta de eficiência de seu controle, especialmente, mas não exclusivamente, do controle jurisdicional. Isso porque um processo, pela sua própria natureza, demora um determinado tempo para ser julgado. Isto é, o juiz não pode julgar assim que apresentada a demanda, tendo de chamar as partes para apresentarem suas razões com prazos específicos para que se defendam. ${ }^{410}$

Por isso, no controle principal, em que o Supremo Tribunal Federal se configura como instância inicial, questões orçamentárias, que são sempre de grande relevo jurídico e social, podem ser decididas diretamente pela instância máxima judicial do país, não deixando espaço para inconstitucionalidades tão danosas ao ordenamento e à sociedade.

No próximo capítulo, o problema será demonstrado a partir da análise das decisões do Supremo Tribunal Federal até o precedente da ADI n ${ }^{\circ} 4.048$, que afastavam a possibilidade de controle de constitucionalidade de leis e normas orçamentárias sob o pretexto de que seriam leis de efeitos concretos, sem característica normativa, portanto.

No entanto, como já observado, não é possível interpretar na Constituição ou na legislação infraconstitucional a restrição ao controle por ADI de normas concretas, categoria na qual as leis orçamentárias são erroneamente enquadradas.

Mas o efeito mais maléfico da jurisprudência que deixa de realizar o controle de constitucionalidade sobre atos de efeitos concretos, afirma Gilmar Mendes, é que "A extensão dessa jurisprudência, desenvolvida para afastar do controle abstrato de normas os atos administrativos de efeito concreto, chamadas leis formais, suscita, sem dúvida, alguma insegurança, porque coloca a salvo do controle de constitucionalidade um sem-número de leis". 411

Em outros países, como França, Espanha e Portugal, o controle de constitucionalidade é efetuado em sede principal.

${ }^{410}$ CHRISTOPOUlOS, Basile G. C. Despesa Pública: estrutura, função e controle judicial. Maceió: Edufal, 2011, p. 165 e 166.

${ }^{411}$ MENDES, Gilmar Ferreira. Controle Abstrato de Constitucionalidade: ADI, ADC e ADO. São Paulo: Saraiva, 2012, p. 137. 
$\mathrm{Na}$ França, o controle de constitucionalidade efetuado pelo Conselho Constitucional é comum e foi feito diversas vezes. Uma das primeiras e mais conhecidas decisões é a que declarou a inconstitucionalidade da totalidade do orçamento para o ano de 1980. O sistema orçamentário francês, como visto, divide a aprovação do orçamento em dois momentos. Acontece que quando da votação do orçamento para o ano de 1980 não houve a aprovação da primeira parte, devido à abstenção de um grupo parlamentar significante. A segunda parte foi votada e aprovada, porém carregando tal vício procedimental. $^{412}$

Como esclarece Tiago Duarte:

A referida lei foi submetida ao Conselho Constitucional que, surpreendentemente, a declarou inconstitucional, por ter sido discutida a segunda parte sem ter sido aprovada a primeira parte, em violação do previsto no art. 40 da Lei Orgânica de 1959, que determina que a segunda parte da lei de finanças do ano não pode ser colocada em discussão perante o Parlamento antes do voto da primeira parte. ${ }^{413}$

Diante do vazio legislativo, e para contornar o vácuo de lei orçamentária, ou a "anomia orçamentária", o governo francês produziu e conseguiu a aprovação de outra lei que permitisse a cobrança dos tributos e demais receitas, ${ }^{414}$ até a aprovação de uma nova lei, o que apenas ocorreu no ano civil seguinte. ${ }^{415}$ Tal lei também fora questionada no Conselho Constitucional, que a declarou conforme a Constituição, ${ }^{416}$ muito provavelmente por razões consequencialistas, pois não havia previsão a autorizar outra lei que não a lei orçamentária a regular a matéria de conteúdo exclusivo.

Tiago Duarte relata que na Espanha há uma grande litigiosidade no que diz respeito à matéria de lei orçamentária:

Assim, refira-se que desde a lei de Orçamento para 1981, até à lei do Orçamento para 1994, apenas a lei de Orçamento para 1991 e para 1993 não foram objecto de sindicância constitucional, tendo-se atingido o recorde de a lei do Orçamento para 1984 ter sido objecto de nove sentenças do Tribunal Constitucional (...). ${ }^{417}$

\footnotetext{
${ }^{412}$ DUARTE. Tiago. A Lei por Detrás do Orçamento: a questão constitucional da lei do orçamento. Coimbra: Almedina, 2007, p. 353.

${ }^{413}$ Idem, Ibdem.

414 Na França a lei orçamentária também é condição para a cobrança de tributos.

415 DUARTE. Tiago. A Lei por Detrás do Orçamento: a questão constitucional da lei do orçamento. Coimbra: Almedina, 2007, p. 353.

416 Idem, Ibdem.

${ }^{417}$ Idem, p. 375.
} 
O autor também afirma que é possível observar mudanças na jurisprudência constitucional no sentido de maior rigor no controle do conteúdo material das leis orçamentárias, cujo marco teria sido a sentença 76/1992. Esta entendeu que algumas normas daquela lei orçamentária não poderiam ter tido aquele veículo de introdução ao ordenamento. $^{418}$

Em Portugal, recentemente se julgou inconstitucional uma disposição da lei orçamentária em função da ofensa ao princípio da igualdade. ${ }^{419}$ A lei orçamentária para o ano de 2013, diante da crise por que passa o país, restringiu uma série de direitos apenas dos servidores públicos, como a suspensão de férias, $14^{\circ}$ salário etc.

O tribunal constitucional português já havia decidido em outra questão, citada no acórdão, declarando a inconstitucionalidade das normas do $\operatorname{artigo} 21^{\circ}$ e do artigo $25^{\circ}$ da Lei do Orçamento para 2012, que a

repartição desigual de encargos públicos com o equilíbrio financeiro do Estado entre, por um lado, trabalhadores ativos do setor público (artigo $21^{\circ}$ ) e reformados e pensionistas ( $\operatorname{artigo} 25^{\circ}$ ), a quem foi determinada a suspensão dos subsídios de férias e de Natal e, por outro, os trabalhadores ativos do setor privado, a quem não foi exigido um sacrifício idêntico. ${ }^{420}$

Nesse caso, do orçamento para 2013, o Tribunal entendeu por declarar a inconstitucionalidade, com força obrigatória geral, por violação do princípio da igualdade, consagrado no artigo $13^{\circ}$ da Constituição da República Portuguesa, da norma do artigo $29^{\circ}$ da Lei $\mathrm{n}^{\mathrm{o}}$ 66-B/2012, de 31 de dezembro. ${ }^{421}$

A disposição final da decisão do Tribunal Constitucional português dá o argumento decisivo em favor da necessidade do controle de constitucionalidade principal no caso de leis orçamentárias, o que chamou de "força obrigatória geral".

Embora cada vez mais o processo de controle incidental esteja se objetivando, isto é, sendo julgado independentemente do caso concreto e produzindo efeitos erga omnes, sem dúvida o controle principal fornece maior segurança. É que os efeitos da sua declaração são mais fortes do ponto de vista institucional e retórico na formação de precedentes que irão orientar as decisões futuras.

\footnotetext{
${ }^{418}$ Idem, p. 386.

419 PORTUGAL. Tribunal Constitucional. Acórdão no 187/2013. Disponível em: <http:// Www.tribunalconstitucional.pt/tc/acordaos/20130187.html>. Acesso em 8.4.2013.

${ }^{420}$ Idem.

${ }^{421}$ Idem.
} 


\section{CAPÍTULO 3. ANÁlise DAS DECISÕES NO CONTROLE DE CONSTITUCIONALIDADE PRINCIPAL DE LEIS E NORMAS ORÇAMENTÁRIAS NO BRASIL: O PRECEDENTE ESTABELECIDO NO SUPREMO TRIBUNAL FEDERAL E AS CONCLUSÕES SOBRE O USO DE ARGUMENTOS CONSEQUENCIALISTAS}

3.1 Método de análise dos argumentos nas decisões do Supremo Tribunal Federal

3.2 Análise das decisões proferidas no controle principal de leis e normas orçamentárias

3.2.1 ADI 1.640/DF: destinação dos recursos da CPMF

3.2.2 ADI 2.100/RS: perda da eficácia da LDO

3.2.3 ADI 2.108/PE: perda da eficácia da LDO

3.2.4 ADI 2.535/MT: norma na LDO sobre precatórios

3.2.5 ADI 2.925/DF: destinação dos recursos da CIDE

3.2.6 ADI 4.048/DF: crédito extraordinário por Medida Provisória

3.2.7 ADI 4.049/DF: crédito extraordinário por Medida Provisória

3.2.8 ADI 4.904/DF: crédito extraordinário por Medida Provisória

3.2.9 ADCs e ADOs

3.2.10 ADPFs

3.3 Qual o precedente estabelecido pelo Supremo Tribunal Federal no controle de constitucionalidade de leis e normas orçamentárias?

3.4 Conclusões sobre o impacto dos argumentos consequencialistas nas decisões do controle de constitucionalidade de leis e normas orçamentárias no Brasil

\subsection{Método de análise dos argumentos nas decisões do Supremo Tribunal Federal}

Há quatro recortes principais quando se pretende analisar jurisprudencialmente um tema relevante. Sobre a metodologia da análise jurisprudencial, afirma-se que seriam recortes jurisprudenciais todas "as estratégias de delimitação do tema" e que "os cortes mais recorrentes são os institucionais, os temáticos, os processuais e os temporais". ${ }^{422}$

O primeiro recorte, institucional, seria a delimitação da pesquisa em uma ou mais instituições. No caso desta tese, o tema é restrito ao Supremo Tribunal Federal. O segundo, temático, corresponde justamente à delimitação quanto ao tema pesquisado. Temse, no caso particular, a análise das leis e normas orçamentárias. ${ }^{423} \mathrm{O}$ recorte temporal,

\footnotetext{
422 PALMA, Juliana B., FEFERBAUM, Marina, PINHEIRO, Victor M. Meu Trabalho Precisa de Jurisprudência? Como Posso Utilizá-la?, in QUEIROZ, Rafael Mafei \& FEFERBAUM, Marina. (Coord.). Metodologia Jurídica: um roteiro prático para trabalhos de conclusão de curso. São Paulo: Saraiva, 2012, p. 144 e 145.

${ }^{423}$ Nesse caso, o termo normas orçamentárias complementa o significado de lei, por abranger também as normas que modificam a execução das leis orçamentárias, como as Mediadas Provisórias, além de entender
} 
relacionado ao "período no qual as decisões que serão analisadas foram proferidas", está consubstanciado no período da Constituição vigente, desde 1988, portanto. Por fim, o recorte processual, quando elementos de natureza processual, como o tipo de recurso ou de processo analisado é o foco de determinada pesquisa, ${ }^{424}$ traduz-se nesta tese pelos processos de controle principal da constitucionalidade das leis orçamentárias.

Além desses recortes, é preciso estabelecer o método de escolha das decisões. Sobre essa escolha dos acórdãos a serem analisados, é preciso dizer que se deu em razão da importância da decisão na formação da jurisprudência do tema no Supremo Tribunal Federal. Além da própria citação em outros acórdãos, os artigos científicos que foram publicados sobre o controle de constitucionalidade na área do direito financeiro ${ }^{425}$ também indicaram as fontes iniciais de pesquisa, isto é, os pontos de partida para o estudo e a escolha dos acórdãos mais importantes da área.

As decisões que serão analisadas a seguir neste capítulo percorrerão um método semelhante de observação, que consistirá numa classificação dos argumentos centrais utilizados pelas decisões em três feixes: a) argumentos deontológicos; b) argumentos consequencialistas jurídicos; c) argumentos consequencialistas econômicos ou extrajurídicos.

A divisão dos argumentos principais dos acórdãos nesses três grupos é evidentemente funcional para os objetivos da tese. É uma classificação útil nesse sentido por possibilitar a análise da utilização de argumentos dessa natureza no controle de constitucionalidade de normas orçamentárias.

Há, implicitamente ou não, uma prescrição de que tipo de argumento consequencialista é possível ou adequado racionalmente no direito, a partir da conclusão de que os argumentos do terceiro tipo não seriam adequados. Isto é, argumentos classificados como extrajurídicos em tese seriam desaconselhados para uma boa decisão, ou uma decisão convincente.

que o controle se dá sobre as normas produzidas, não apenas sobre os veículos normativos vistos como um todo indivisível.

424 PALMA, Juliana B., FEFERBAUM, Marina, PINHEIRO, Victor M. Meu Trabalho Precisa de Jurisprudência? Como Posso Utilizá-la?, in QUEIROZ, Rafael Mafei \& FEFERBAUM, Marina. (Coord.). Metodologia Jurídica: um roteiro prático para trabalhos de conclusão de curso. São Paulo: Saraiva, 2012, p. 144 e 145.

${ }^{425}$ ASSONI FILHO, Sérgio. Controle de Constitucionalidade de Lei Orçamentária, in CONTI, José Maurício \& SCAFF, Fernando Facury (Org.). Orçamentos Públicos e Direito Financeiro. São Paulo: Revista dos Tribunais, 2011; CORREIA NETO, Celso de Barros. O Orçamento Público e o Supremo Tribunal Federal, in CONTI, José Maurício \& SCAFF, Fernando Facury (Org.). Orçamentos Públicos e Direito Financeiro. São Paulo: Revista dos Tribunais, 2011; NEME, Eliana F. \& ARAUJO, Luiz Alberto D. O Controle de Constitucionalidade Concentrado de Normas Orçamentárias, in CONTI, José Maurício \& SCAFF, Fernando Facury (Org.). Orçamentos Públicos e Direito Financeiro. São Paulo: Revista dos Tribunais, 2011. 
Cada argumento será ainda observado em relação à alegação que pretende provar, as premissas que o embasam, as conclusões que dele podem ser extraídas e a importância ou relevância para a decisão ou para a formação do precedente sobre a matéria.

A decomposição de tais argumentos seguirá essencialmente uma linha descritiva dos acórdãos, a fim de que seja possível afirmar ao final a centralidade de argumentos consequencialistas nas decisões de modo a comprovar a hipótese de que os argumentos consequencialistas são sim fundamentais na análise do controle de constitucionalidade de normas orçamentárias realizado pelo Supremo Tribunal Federal no Brasil.

Além disso, em cada acórdão analisado serão levantados cinco pontos: 1) Contexto do Acórdão e Dispositivos Atacados; 2) Argumentos Deontológicos (AD); 3) Argumentos Consequencialistas Jurídicos (ACJ); 4) Argumentos Consequencialistas Extrajurídicos (ACE); e 5) Análise da Composição de Argumentos. O primeiro ponto visa estabelecer as primeiras impressões do acórdão, bem como o contexto em que ele foi produzido. Os três pontos seguintes buscam catalogar os principais argumentos utilizados, lançando-se mão da classificação citada nos parágrafos anteriores. O último ponto servirá para fazer um balanço dos argumentos utilizados no acórdão, bem como um diagnóstico final sobre a relevância dos argumentos consequencialistas em cada decisão.

\subsection{Análise das decisões proferidas no controle principal de leis e normas orçamentárias}

Vistas as principais escolhas metodológicas, neste segundo item do capítulo serão analisadas as decisões no controle de constitucionalidade principal que tenham por objeto leis e normas orçamentárias, ou seja, sobre as normas introduzidas pelas leis orçamentárias (PPA, LDO e LOA), além de normas orçamentárias que as modifiquem, como no caso das veiculadas por Medidas Provisórias que alterem a legalidade orçamentária.

Observou-se nos últimos anos um grande número de decisões sobre leis e normas orçamentárias no Supremo Tribunal Federal, o que possibilitará a análise encadeada historicamente das decisões, averiguando inclusive um das sub-hipóteses desta 
tese, que é a diminuição da autorrestrição do Poder Judiciário, neste caso, do Supremo Tribunal Federal, na análise de leis orçamentárias. Isto é, observar-se-á neste capítulo, e especialmente nos itens a seguir, se o STF vem aumentando os casos e hipóteses de controle de constitucionalidade de leis e normas orçamentárias no controle principal.

Esta hipótese está relacionada à hipótese principal, também investigada neste item, sobre o uso de argumentos consequencialistas nas referidas decisões. Nesses casos, decidem-se as questões de constitucionalidade com um uso acentuado de argumentos orientados à produção de consequências e não meramente deontológicos, nos sentidos tratados anteriormente, especialmente na primeira parte da tese.

Nesta subdivisão, os acórdãos proferidos em sede de Ação Direta de Inconstitucionalidade - ADI serão analisados individualmente, enquanto nas demais vias de acesso ao controle principal, Ação Declaratória de Constitucionalidade - ADC, Ação Direta de Inconstitucionalidade por Omissão - ADO e Arguição de Descumprimento de Preceito Fundamental - ADPF, os acórdãos serão analisados em conjunto, pelas razões que serão expostas nos respectivos itens.

\subsubsection{ADI 1.640/DF: destinação dos recursos da $\mathrm{CPMF}^{426}$}

\section{Contexto do Acórdão e Dispositivos Atacados}

O acórdão foi escolhido pela sua importância ao representar o paradigma anterior e, pode-se dizer, ultrapassado do Supremo Tribunal Federal, por considerar as leis orçamentárias meramente "leis de efeitos concretos" não passíveis de controle principal de constitucionalidade, nomeadamente as ADIs.

A petição inicial, proposta pelo Partido dos Trabalhadores, oposição na época, questionava a destinação disposta pela Lei Orçamentária Anual de 1997, Lei 9.438/97, dos recursos auferidos pela arrecadação da CPMF.

Enquanto a Emenda Constitucional 12, de 1996, que a criou exigia a destinação integral dos recursos para financiamento das ações e serviços de saúde, a petição alegava a destinação dos recursos classificados pela origem da CPMF para o programa de amortização da dívida e, ainda, juros e encargos de financiamento, num desvio de finalidade constitucional de $27,24 \%$ dos recursos totais daquele tributo.

\footnotetext{
${ }^{426}$ STF. ADI de no 1.640. Rel. Min. Sydney Sanches. Publicado no DJ de 3.4.1998.
} 
Foram alegados a lesão ao patrimônio público e o desrespeito à moralidade administrativa.

Foi citado o artigo $18^{427}$ da Lei 9.311/96, que criou a CPMF autorizada constitucionalmente e que também previa a destinação integral dos recursos para a área da saúde, mais especificamente para o Fundo Nacional de Saúde.

Alega-se também que a população brasileira quando autorizou a criação do tributo o fez com o fim de financiar a saúde, e que não teria conhecimento da destinação outra que fora dada, de forma que não seria lícito, ético, nem legal que a população pagasse por uma dívida não adequada às finalidades expressas na lei e na Constituição Federal.

Alega-se ainda que:

A não aplicação dos recursos destinados à saúde tal qual previsto na Constituição Federal e na Legislação Infraconstitucional, tem consequências maléficas para a população, que além do mau atendimento, agora se depara com outra realidade nos hospitais: a falta de recursos, a falência da saúde e a inadimplência do Governo Federal.

Por fim, foi alegada a ofensa ao artigo $74, \S 3^{\circ}$, do Ato das Disposições Constitucionais Transitórias do dispositivo da Lei Orçamentária Anual de 1997, disposta pela Lei 9.438 daquele ano, pela utilização dos recursos da CPMF, identificados sob o Código 155, no Programa de Trabalho 13.008.0003.3202.7001, destinado ao pagamento de dívida.

Em 14 páginas, só três argumentos são verdadeiramente construídos na decisão. O primeiro é o de que:

\begin{abstract}
Não se pretende, pois, a suspensão cautelar nem a declaração final de inconstitucionalidade de uma norma, mas de uma destinação de recursos, prevista em lei formal, mas de natureza e efeitos político-administrativos concretos, hipótese em que, na conformidade dos precedentes da Corte, descabe o controle concentrado de constitucionalidade como previsto no art. 102, I, "a", da Constituição Federal, pois ali se exige que se trate de ato normativo.
\end{abstract}

Em seguida o Ministro formula um argumento sobre a jurisprudência do Supremo Tribunal Federal, citando a ADI de $n^{\circ} 203$, segundo a qual recusou-se o controle

\footnotetext{
427 “Art. 18. O produto da arrecadação da contribuição de que trata esta Lei será destinado integralmente ao Fundo Nacional de Saúde, para financiamento das ações e serviços de saúde, sendo que sua entrega obedecerá aos prazos e condições estabelecidos para as transferências de que trata o art. 159 da Constituição Federal”. BRASIL. Lei 9.311/96.
} 
de constitucionalidade de "transferências de recursos de uma rubrica para outra" na proposta orçamentária.

Argumenta-se, por fim, no acórdão, restar ao controle desse tipo de norma a via incidental:

Lembro que, no precedente de que foi Relator o eminente Ministro CELSO DE MELLO, no Agravo Regimental em ADI no 203, ficou registrado no tópico final do voto de S. Exa. (RTJ 131/1007):Apenas registro que a recusa do controle em tese da constitucionalidade da emenda congressional, consistente em mera transferência de recursos de uma rubrica para outra, dentro da Proposta Orçamentária do Governo Federal, não traduz a impossibilidade de verificação de sua legitimidade pelo Poder Judiciário, sempre cabível pela via do controle incidental. Sendo assim, nada impede que eventuais prejudicados se valham das vias adequadas ao controle difuso de constitucionalidade, sustentando a inconstitucionalidade da destinação de recursos, como prevista na Lei em questão.

O acórdão foi julgado por unanimidade, presentes os Ministros: Celso de Mello, Moreira Alves, Néri da Silveira, Sydney Sanches, Octavio Gallotti, Sepúlveda Pertence, Carlos Velloso, Marco Aurélio, Maurício Corrêa, Nelson Jobim.

\section{Argumentos Deontológicos (AD)}

O principal argumento deontológico apresentado na decisão é o de que não se trata de "uma norma, mas de uma destinação de recursos",

A alegação, portanto, é de que não deve ser submetida a norma em análise ao controle de constitucionalidade por ADI, em razão do disposto no artigo art. 102, I, "a", da Constituição Federal.

Algumas premissas relevantes podem ser extraídas dessa citação: a) a norma que se constrói a partir do artigo 102, I, "a”, da Constituição Federal exige que tanto a lei quanto o ato tenham caráter normativo para que haja controle de Constitucionalidade; b) o caráter normativo é expresso pela noção de generalidade e abstração das normas presentes na lei; c) o veículo normativo apenas possui um tipo de norma; d) essa norma única sob análise não possui natureza normativa, mas de efeito político-administrativo concreto.

O argumento certamente é decisivo no acórdão, de forma que se pode classificá-lo como ratio decidendi da decisão. 


\section{Argumentos Consequencialistas Jurídicos (ACJ)}

O principal argumento consequencialista jurídico que se pode apreender do acórdão é o que entende restar o controle incidental para o controle de normas orçamentárias.

$\mathrm{O}$ argumento caracteriza-se como consequencialista por prever a situação jurídica que a decisão pode produzir, nesse caso quando afirma que a decisão não traduz uma impossibilidade de controle de constitucionalidade.

A alegação nesse caso é a de que recusar o controle pela via principal, ADI, não impossibilitaria o controle de constitucionalidade, já que restaria possível o controle incidental.

Essas são as principais premissas que podem ser percebidas no caso: a) todas as normas devem sofrer controle de constitucionalidade; b) normas orçamentárias não são passíveis de controle de constitucionalidade por via principal; c) normas orçamentárias são passíveis do controle de constitucionalidade apenas por via incidental.

O argumento está relacionado ao aspecto central da decisão, que é o não conhecimento da ADI em questão. Compõe, portanto, a ratio decidendi da decisão. Vale lembrar que esse ponto será justamente o questionado nas ADIs seguintes, que tratam sobre o mesmo tema.

\section{Análise da Composição de Argumentos}

Os dois argumentos principais do acórdão tratam da admissibilidade do recurso para tratar da questão orçamentária, posto que a ação não tenha sido conhecida. $\mathrm{O}$ argumento deontológico pretende demonstrar que o artigo 102, I, “a”, da Constituição Federal exige que se trate de ato normativo para que haja controle de constitucionalidade pela via eleita, e que as normas orçamentárias, por serem instrumentos políticoadministrativos, não seriam passíveis desse controle. $\mathrm{O}$ argumento consequencialista jurídico analisa as consequências jurídicas da decisão, especulando sobre qual seria a via adequada para a proposição de questões semelhantes. Estabelece que a via adequada no futuro para casos semelhantes seria a do controle difuso ou incidental, de forma que as normas não restariam sem controle de constitucionalidade. 


\subsubsection{ADI 2.100/RS: perda da eficácia da $\mathrm{LDO}^{428}$}

\section{Contexto do Acórdão e Dispositivos Atacados}

A ADI 2.100-1/RS questionou a constitucionalidade da Lei de $\mathrm{n}^{\circ} 11.324$, do estado do Rio Grande do Sul, que dispunha diretrizes para a elaboração do orçamento para o ano de 2000.

Nesse caso, as normas dispostas pela LDO seriam contrárias às disposições do PPA daquele estado, confrontando o artigo $166, \S 4^{\circ}$, da Constituição, no que se chama de inconstitucionalidade reflexa. Além disso, a LDO teria vinculado receita à destinação em descompasso ao artigo 167, IV, do texto constitucional.

$\mathrm{Na}$ petição inicial, um dos argumentos interessantes (e consequencialistas) levantados foi o de que os dispositivos atacados, permanecendo em vigor, tumultuariam o processo de discussão da LOA na Assembleia, pois faria retornar o debate já avançado, além do que poderia comprometer a efetiva aprovação do orçamento até o fim do ano.

Foi levantado, em oposição, o argumento da perda da eficácia da Lei de Diretrizes Orçamentárias, uma vez que, aprovada a LOA orientada por esta, ela teria exaurido todos os seus efeitos possíveis, não produzindo nenhum efeito para a LOA criada.

A ADI não foi conhecida, exatamente sob tal fundamento, o de que "cessou a eficácia na LDO”. É possível observar que o argumento tem dois vieses: um deontológico e outro consequencialista. Mas o predominante é o consequencialista. Explica-se: o controle de constitucionalidade não serve para controlar centralmente a eficácia da lei, mas sim a validade de uma lei. É evidente que os efeitos são considerados, mas em segundo plano, vide modulação de efeitos. Por que, então, não controlar a validade de uma norma que deixou de produzir efeitos? Pela suposta inutilidade da decisão, que deixaria de ser aproveitada, uma vez que não há mais efeitos a produzir.

Por fim, o Ministro relator para o acórdão, Nelson Jobim, confunde as noções de efeitos concretos com a natureza jurídica das normas questionadas, quando afirma que:

são normas tipicamente concreta (sic), de conteúdo político, porque o orçamento de 1999 foi votado em 1998, no governo anterior. Isso significa a sobrevida da política orçamentária do governo anterior para o ano de 2000, que é o período em que o novo governo tem condições de implantar a sua política.

${ }^{428}$ STF. ADI de nº 2.100. Rel. Min. Néri da Silveira. Publicado no DJ de 1.6.2001. 
A decisão foi proferia por maioria. Vencedores os Ministros: Carlos Velloso, Moreira Alves, Sydney Sanches, Octavio Gallotti, Sepúlveda Pertence, Ilmar Galvão, Maurício Corrêa, Nelson Jobim (relator p/ acórdão). Ministros vencidos: Néri da Silveira, Marco Aurélio. Ministros ausentes: Celso de Mello.

\section{Argumentos Deontológicos (AD)}

O primeiro argumento deontológico é o da inconstitucionalidade reflexa (artigo 166, $\S 4^{\circ}$, da Constituição). Ou seja, quando uma lei contraria o conteúdo estipulado por outra lei, de igual hierarquia, mas fere artigo constitucional. Neste caso ele acabou não influenciando decisivamente a decisão, constituindo, portanto, obiter dictum. Segundo esse argumento, o controle principal não pode ser feito quando uma norma apenas contraria outra de igual hierarquia, porém atingindo reflexamente norma constitucional. Nesse caso, normas dispostas pela LDO seriam contrárias às disposições do PPA daquele estado.

São premissas desse argumento: a) há diferenças no sistema de controle de constitucionalidade brasileiro em relação aos critérios exigidos no controle principal e no incidental; b) não há hierarquia entre as normas orçamentárias; c) as normas orçamentárias, por outro lado, precisam respeitar o conteúdo das demais.

Outro argumento deontológico, que será predominante em outras ações, mas nesse teve um papel menor, foi o de que não devem ser conhecidas ações no controle principal cujo objeto seja uma lei de efeitos concretos, como levantado pelo Ministro Jobim.

Os pressupostos são os mesmos da ADI 1.640, expostos anteriormente para o mesmo argumento, acrescidos da premissa de que leis de efeito concreto não apenas não são normas, como são atos de natureza política, por isso insuscetíveis ao controle de constitucionalidade.

\section{Argumentos Consequencialistas Jurídicos (ACJ)}

A ADI não foi conhecida sob o fundamento de que "cessou a eficácia na LDO”. A alegação desse argumento é o não conhecimento da ação, com fundamento nos efeitos irrelevantes que a decisão proferida produziria para o caso. 
Isto é, mesmo que a análise da constitucionalidade seja uma análise de validade, e não de eficácia, o tribunal prefere não se manifestar quando supõe que os efeitos de sua decisão não serão úteis ao caso ou ao ordenamento.

Foram eleitas as principais premissas do argumento: a) a decisão de um tribunal precisa produzir efeitos úteis ao caso; b) a eficácia da norma analisada é essencial requisito de conhecimento da ação; c) a LDO, uma vez produzida a LOA, deixa de ter efeitos.

O argumento em questão foi central para a decisão de não conhecer a ação; não poderia deixar de ser, pois, ratio decidendi na questão.

Outro argumento consequencialista, este, obiter dictum, de valor menor na decisão, é a citada alegação da petição inicial de que "a permanecerem em vigor tais dispositivos, o Estado seria obrigado a praticar ato concreto que implicaria descumprimento de deveres constitucionais postos no art. 167, § $1^{\circ}$, da Constituição Federal".

O argumento é consequencialista porque especula qual será a obrigação jurídica estabelecida pelo STF caso ocorra decisão pela continuidade da vigência de dispositivos questionados.

\section{Argumentos Consequencialistas Extrajurídicos (ACE)}

O único argumento extrajurídico levantado não foi utilizado propriamente como razão decisória, mas apenas citado como argumento levantado na petição inicial para defender a necessidade de declaração de inconstitucionalidade dos dispositivos atacados, que,

(...) a permanecerem em vigor, tumultuarão o processo de discussão na Assembléia Legislativa, da proposta orçamentária já que, mercê destes dois dispositivos, o rumo dos debates, já avançado, teria de retornar a fases já superadas, de tal sorte que haveria, efetivamente, comprometimento à ordem dos trabalhos parlamentares e, ao final, haja mesmo a possibilidade de o Estado ficar sem orçamento ao final do ano ou de a decisão deste Pretório restar ineficaz.

A alegação que o argumento levanta é a necessidade de se julgar inconstitucionais os dispositivos atacados. Para isso, o argumento pressupõe os seguintes termos: a) as consequências diante da demora do julgamento seriam desastrosas; b) o processo orçamentário depende do resultado do julgamento pelo STF; c) a anomia 
orçamentária, isto é, ficar sem orçamento, é um problema grave e que traz grandes prejuízos às ações estatais.

O argumento, no entanto, não faz parte do núcleo essencial da decisão, constituindo, se muito, um obiter dictum.

Apesar de a maioria das premissas estar correta, todas as consequências apontadas pelo argumento não decorrem da produção da norma, mas sim da própria judicialização da causa, na qual contribuiu decisivamente, propondo a ação em questão. Resta também uma crítica à segunda premissa (b), pois o processo orçamentário não depende do julgamento do STF, podendo ser alterados itens específicos diante de declarações de possíveis inconstitucionalidades.

\section{Análise da Composição de Argumentos}

Nesse acórdão é possível defender uma predominância de argumentos consequencialistas jurídicos, porquanto o principal argumento da decisão possui tal natureza.

No entanto, entende-se equivocado tal argumento, de que a LDO perde sua eficácia com a produção da LOA. Na verdade, apenas no fim do ano de execução da LOA, ambas deixam de produzir efeitos conjuntamente, uma vez que a orientação conferida pela LDO não serve apenas para a produção inicial da LOA, senão também para as eventuais que sejam necessárias durante tal execução.

Mesmo considerando que a LDO perdeu sua eficácia, não se deve supor que as decisões que constituam sua inconstitucionalidade seriam inúteis. É que a decisão de inconstitucionalidade, mesmo em normas com eficácia exaurida, não produz efeitos no ordenamento, como a formação de precedentes.

Por fim, sobre o argumento acerca da natureza política ou não normativa das leis orçamentárias, já foi estabelecido, no primeiro capítulo da segunda parte, a noção de normas concretas e abstratas, ambas jurídicas e que não se confundem com nenhuma noção de norma de conteúdo político. O direito não pode aceitar tal distinção porque ela é inexata e improdutiva, já que dá a entender que algumas normas veiculadas por lei não fazem nenhum sentido jurídico, apenas estipulam vontades, como há tempos não se admite mais, por exemplo, em relação às normas constitucionais. 


\subsubsection{ADI 2.108/PE: perda da eficácia da $\mathrm{LDO}^{429}$}

\section{Contexto do Acórdão e Dispositivos Atacados}

Nesta ação é questionada a constitucionalidade de dispositivo que modificou a Lei de Diretrizes Orçamentárias - LDO do estado de Pernambuco, produzida no ano de 2000.

A norma questionada estabeleceu reduções nas participações do Poder Judiciário, do Ministério Público, do Tribunal de Contas e da Assembleia Legislativa do montante da arrecadação, e o fez com base nos valores da receita orçamentária desvinculada líquida.

A alegação é que a vinculação de receita trazida pela norma seria contrária aos artigos 99, 165 e 167 da Constituição Federal. Isto é, seria impossível vincular percentual de receita de impostos a despesas públicas específicas em espécie não autorizada pela Constituição Federal.

O Relator, Ministro Marco Aurélio, estabelece em seu voto que não estaria configurada uma simples limitação das despesas, como alegado em contestação, mas a vinculação de recursos decorrentes de impostos. Diante disso, o Ministro entendeu por deferir a medida liminar, suspendendo até a data do julgamento final a eficácia dos artigos questionados na ADI.

Os ministros, então, passaram a discutir sobre a natureza jurídica das leis orçamentárias. No início de seu voto, o Ministro Sepúlveda Pertence afirma que:

Quanto à norma geral e concreta, volto à celebre (sic) explicação de Kelsen: emite norma geral o pai que ordena ao seu filho único que deve ir à missa todo domingo, porque regula um número indeterminado de ações futuras. É norma concreta a emitida pelo pai de vinte filhos que lhes ordena que, em determinado domingo, visitem o Padre Fulano.

Foi questionado pelo Ministro Jobim sobre a incidência da LDO no caso, quando afirma que: “Quando o governador elabora e envia a proposta de lei orçamentária anual, a LDO pode ser retirada do vade-mécum estadual. Ela já incidiu e não vai incidir

${ }^{429}$ STF. ADI de n ${ }^{\text {o }}$ 2.108. Rel. Min. Marco Aurélio. Publicado no DJ de 30.4.2004. 
mais". O Ministro Jobim defende que a incidência da receita se dará pelo ano todo, não apenas uma única vez.

O relator do caso, Ministro Marco Aurélio, reconhece o caráter normativo projetado no tempo de elaboração da lei orçamentária, e diz: "devo concluir que estou diante de um ato normativo de eficácia abstrata". Nesse sentido, o Ministro Néri da Silveira afirma que, tendo em vista a não aprovação da LOA, ainda é possível discutir a validade da LDO em questão.

Segundo o Ministro Jobim:

Não obstante a vinculação entre uma lei e outra, no sentido de que o plano plurianual de investimentos fixa as linhas gerais das ações públicas orçamentárias brasileiras, e também a lei orçamentária nada mais é do que a execução do plano plurianual no que diz respeito ao ano subsequente e o orçamento nada mais seria do que a execução orçamentária da decisão estabelecida nas leis anteriores, o que se passa, na verdade, é que essas três leis brasileiras não têm hierarquia diversa. Ou seja, a lei do plano plurianual, a lei de diretrizes orçamentárias e a lei orçamentária estão no mesmo plano. Portanto, um dispositivo como este que está na lei de diretrizes orçamentárias pode ser rigorosamente alterado na votação da lei orçamentária, porque a lei orçamentária não tem status inferior à lei de diretrizes orçamentárias.

E conclui o Ministro Jobim que qualquer disposição da LOA que contrarie norma da LDO “importa na revogação do seu dispositivo”. O Ministro Sepúlveda Pertence discorda da posição adotada, afirmando que nesse caso ter-se-ia uma “inconstitucionalidade reflexa por violação da norma infraconstitucional interposta".

O Ministro Moreira Alves afirma que nesse caso de inconstitucionalidade reflexa, o meio adequado seria o controle difuso. Aduz o Ministro Pertence:

Seria muito simpático que admitíssemos ações diretas para o controle de normas concretas de hierarquia legal, mas essa não é a jurisprudência do Tribunal, é norma que tenha o chamado coeficiente bastante de generalidade e abstração. A partir daí, não discordo de que se trate de uma norma; agora, é um exemplo de escola, para o meu entendimento, que se trata de uma norma concreta e o critério foi o que estabeleci: é norma concreta, óbvio, regulando a ação futura, ou não será norma, mas que se esgotará num ato único, ou de cumprimento, ou de descumprimento dela - é o que ocorre. 
Interessante observar que este Ministro reconhece a inconstitucionalidade, mas reafirma a incapacidade ou a incompetência para constituí-la diante, simplesmente, da via eleita, o controle principal por ADI.

O Ministro Néri da Silveira demonstra preocupação com a falta de controle de constitucionalidade das normas orçamentárias diante dos obstáculos colocados pelo Tribunal naquela decisão. Já o Ministro Sepúlveda Pertence afirma que "o seu temor de que a inconstitucionalidade seja irremediável não faz jus aos jovens membros do Ministério Público, espalhados pelo País: com uma linda ação civil pública, como essa que V. Exa. acaba de bosquejar, haverá uma tutela antecipada. Não tenha dúvida”.

O Ministro Silveira dispõe o que mais tarde viria a ser confirmado na ADI 2.925, que "Nesse caso não se conhece, mas se estabelece uma disposição geral a respeito da elaboração orçamentária. Nesse caso, há norma jurídica e a ação de inconstitucionalidade é admissível".

O Ministro Ilmar Galvão toca no ponto central que destrói a tese de que a LDO se esgotaria com a positivação da LOA, quando questiona se "essa lei não regula também os créditos adicionais que vierem depois, durante o exercício”. E o Ministro Sepúlveda Pertence, desconhecendo o papel da LDO, afirma: "Eu acho que não".

Os Ministros encerram a discussão sem estabelecer exatamente que tipo de efeitos produz a LDO.

Julgado em 17.12.1999, por maioria, vencedores os Ministros Moreira Alves, Sydney Sanches, Octavio Gallotti, Carlos Velloso, Sepúlveda Pertence, Ilmar Galvão, Maurício Corrêa, Nelson Jobim, vencidos os Ministros Marco Aurélio e Néri da Silveira, o Supremo Tribunal Federal não conheceu da ação direta de inconstitucionalidade.

\section{Argumentos Deontológicos (AD)}

O primeiro argumento puramente deontológico é o que baseia a inconstitucionalidade da norma na impossibilidade de vincular percentual da receita de impostos a despesas públicas específicas.

São premissas desse argumento: a) a Constituição Federal veda a vinculação da receita de impostos a despesas específicas; b) leis orçamentárias, nesse caso a LDO, estão impedidas de vincular a destinação da receita de impostos. 
O único problema desse raciocínio é o da premissa de que leis orçamentárias não podem destinar recursos públicos. Isto é, a norma constitucional que veda a vinculação de receitas a impostos apenas o faz para que a lei orçamentária, especialmente a LOA, possa fixar livremente os recursos dos impostos. Esse argumento é decisivo para o julgamento da ação.

Mas o principal argumento do acórdão é o que especula sobre a generalidade e a abstração das normas, também deontológico e, nesse caso, ratio decidendi, por fundamentar o não conhecimento da ação que prevaleceu.

\section{Argumentos Consequencialistas Jurídicos (ACJ)}

Argumentos foram levantados acerca dos efeitos do não conhecimento da ação, nesse caso menos relevante para o acórdão, mas interessante para a tese pela natureza consequencialista, além do fato de se perpetuar em decisões futuras do controle de leis orçamentárias.

Em contraponto ao argumento, o Ministro Sepúlveda Pertence afirma que "o seu temor de que a inconstitucionalidade seja irremediável não faz jus aos jovens membros do Ministério Público, espalhados pelo País: com uma linda ação civil pública, como essa que V. Exa. acaba de bosquejar, haverá uma tutela antecipada. Não tenha dúvida".

Premissas do argumento contrário à preocupação consequencialista: a) as normas devem ter algum tipo de controle de constitucionalidade; b) não é possível fazer o controle de constitucionalidade principal de normas orçamentárias por via principal; c) a via incidental é suficiente para proteger a Constituição de invalidades nas leis orçamentárias; d) as consequências do não controle por via principal, portanto, não são danosas ao ordenamento e à supremacia constitucional.

\section{Análise da Composição de Argumentos}

No acórdão, as consequências da decisão são avaliadas pelos Ministros. Enquanto parte entende por não conhecer a ação, que não traria efeitos maléficos ao ordenamento, alguns ministros começam a cogitar seu conhecimento, sob pena de se deixar as leis orçamentárias livres de controle.

O debate central é efetivamente sobre a natureza das normas orçamentárias. A única novidade, digna de nota, é a resposta do Ministro Ilmar Galvão, que destrói a tese de 
que a LDO se esgotaria com a positivação da LOA, quando questiona se "essa lei não regula também os créditos adicionais que vierem depois, durante o exercício". E o Ministro Sepúlveda Pertence, desconhecendo o papel da LDO, afirma: "Eu acho que não".

Fica clara a confusão dos Ministros no acórdão sobre o que seria generalidade e abstração, apesar da citarem Hans Kelsen e debaterem longamente sobre o assunto.

Por fim, não é correta a afirmação do Ministro Jobim de que, uma vez aprovada a LOA, a LDO poderia ser retirada do vade-mécum do estado ou da União. Como visto, a vigência da LDO é particular e única, se propagando até o fim da execução da LOA no ano posterior ao da sua elaboração, uma vez que orienta inclusive eventuais modificações feitas à LOA ao longo desse ano.

\subsubsection{ADI 2.535/MT: norma na LDO sobre precatórios ${ }^{430}$}

\section{Contexto do Acórdão e Dispositivos Atacados}

A ADI 2.535-0/MT foi proposta por um partido político contra norma da Lei de Diretrizes Orçamentárias para o ano de 2002. Excluía da regular inscrição em lei orçamentária os precatórios pendentes de pagamento anteriores à data de promulgação da Emenda Constitucional de $n^{\circ} 30 / 2000$ e os que decorressem de ações ajuizadas até 31 de dezembro de 1999.

A petição inicial apontou diversas normas constitucionais feridas, entre elas a separação dos poderes, a da proteção da coisa julgada, do direito adquirido e do devido processo legal. Além do princípio da isonomia, por dispor tratamentos diferenciados para quem possui direitos semelhantes, nesse caso, o de receber os valores constantes em precatórios.

Nas informações prestadas pelo Governador do Mato Grosso, é construído o argumento da inconstitucionalidade reflexa, segundo o qual não se buscaria a declaração de inconstitucionalidade por ofensa direta ao texto constitucional, mas indireta, alegando a impossibilidade de controle principal no caso examinado.

Passando ao exame das questões, o Ministro Sepúlveda Pertence descarta imediatamente a inconstitucionalidade reflexa, por esta se caracterizar "quando o vício de ilegitimidade irrogado a um ato normativo é o desrespeito à Lei Fundamental por haver

${ }^{430}$ STF. ADI de no 2.535. Rel. Min. Sepúlveda Pertence. Publicado no DJ de 21.11.2003. 
violado norma infraconstitucional interposta, a cuja observância estaria vinculado pela Constituição", e que, no caso, buscar-se-ia diretamente a conformidade às normas constitucionais que o preordenam.

Levanta então o debate, não suscitado pelas partes, da exigência do grau de abstração e generalidade das normas em apreço, "conotações essenciais do ato normativo susceptível de controle direto de constitucionalidade, segundo a doutrina assente do Tribunal". Cita como precedente a decisão na ADI 2.100.

E menciona Hans Kelsen, para quem o caráter individual de uma norma

(...) não depende de se a norma é dirigida a um ser humano individualmente determinado ou a várias pessoas individualmente certas ou a uma categoria de homens, ou seja, a uma maioria não individualmente, mas apenas de certas pessoas de modo geral. Também pode ter caráter geral uma norma que fixa como devida a conduta de uma pessoa individualmente designada, não apenas uma conduta única, individualmente determinada, é posta como devida, mas uma conduta dessa pessoa estabelecida em geral.

Voltando ao caso em análise, entende o relator que o dispositivo contestado dispõe duas normas distintas: uma, de organização e competência, que institui comissão para avaliar os precatórios, e outra, de elaboração da LOA, que condiciona a inclusão dos precatórios à manutenção da meta de resultado primário.

Em relação a esta segunda, diz que se trata de exemplo típico de norma individual "ou" de efeitos concretos. Mas, no caso da primeira, que se trata de norma geral, "tanto no ponto em que institui a comissão, quanto naquele em que a incumbe do levantamento e da apuração do valor real de cada um dos precatórios pendentes (...)". E dispõe pelo conhecimento da ação direta, tendo em vista que as normas estariam inseparavelmente conectadas, pois com a declaração da inconstitucionalidade de uma, a outra ficaria sem objeto. Vota ainda, no mérito, pelo deferimento da cautelar, suspendendo a eficácia dos dispositivos questionados na ADI.

O Ministro Ilmar Galvão, questionando a natureza abstrata da norma apontada pelo Ministro Pertence, afirma que os dispositivos, na verdade, apenas regulariam as questões para o ano vigente. Responde o Ministro Pertence: "Sim, Ministro, mas lei temporária não deixa de ser uma norma geral’"

Após os debates sobre a norma examinada, a disposição sobre precatórios no estado do Mato Grosso, o Tribunal decidiu por conhecer a ação, por maioria, suspendendo a sua eficácia até a data final do julgamento da ação, em decisão proferida em 19.12.2001. 
Ministros vencedores: Marco Aurélio, Néri da Silveira, Sydney Sanches, Sepúlveda Pertence, Carlos Velloso, Maurício Corrêa, Nelson Jobim, Ellen Gracie. Ministros vencidos: Ilmar Galvão e Moreira Alves (quanto ao conhecimento da ação. No mérito a liminar foi deferida por unanimidade). Ministro ausente: Celso de Mello

\section{Argumentos Deontológicos (AD)}

Há dois argumentos centrais na decisão. Um foi superado, isto é, o tribunal não o acatou; o outro foi determinante para a decisão.

O primeiro argumento, obiter dictum, foi o da inconstitucionalidade reflexa, também levantado na ADI 2.100. Esse argumento foi rejeitado de início pelo Ministro relator.

O outro argumento, este ratio decidendi, foi novamente sobre a natureza das normas orçamentárias. Na decisão anteriormente analisada, ADI 2.108, já se debateu sobre essa questão, isto é, se normas inseridas em leis orçamentárias seriam concretas ou abstratas, condicionando o conhecimento da ADI ao segundo tipo de norma.

As premissas do argumento são: a) no controle de constitucionalidade principal, apenas normas abstratas podem ser questionadas; b) no caso concreto, tem-se ao menos uma norma de caráter abstrato; c) quando de duas normas questionadas ao menos uma for abstrata, e elas estiverem intrinsecamente relacionadas, a ação deverá ser conhecida.

\section{Análise da Composição de Argumentos}

Dos acórdãos analisados, este é o único que não apresenta argumentos consequencialistas relevantes; no entanto, a importância dessa decisão é destacada, por ter sido a primeira a conhecer e aceitar a possibilidade de que normas contidas no orçamento possam ter sua constitucionalidade averiguada pela via principal. Isso porque a tradição de self-restraint da Corte era a de não conhecer, como afirmado, ações cujo objeto fossem as leis orçamentárias.

A referida ADI mudou este entendimento, dispondo que nem todas as normas orçamentárias eram de efeito concreto, e que naquele caso tratava-se de uma norma geral disposta numa norma orçamentária. 
Os ministros entenderam que seriam duas normas distintas no mesmo dispositivo legal. Numa, instituir-se-ia uma comissão para analisar as questões relativas aos precatórios, essa abstrata. Noutra, voltada para a elaboração da LOA, que condicionaria a inclusão dos precatórios à manutenção da meta de resultado primário, de efeitos concretos.

Aqui parece haver um erro de avaliação sobre a generalidade das normas em análise. Uma norma que cria uma comissão é, claramente, uma norma concreta. Isso porque, uma vez criada a comissão, seus efeitos se exaurem. Seria diferente caso se considerassem normas que disciplinam o funcionamento de uma ou de várias comissões.

O importante, no entanto, da análise dessa decisão é o seu pioneirismo no controle de constitucionalidade de leis e normas orçamentárias. A decisão foi proferida em 2001, em torno de quatro anos antes da decisão na ADI 2.925, a próxima a ser analisada. Apesar disso, essa decisão não teve a repercussão necessária no mundo jurídico para que fosse tida como precedente, seja nas demais decisões, seja na análise doutrinária sobre o tema, sendo menos citada que a decisão que lhe sucedeu.

\subsubsection{ADI 2.925/DF: destinação dos recursos da CIDE $^{431}$}

\section{Contexto do Acórdão e Dispositivos Atacados}

A Ação Direta de Inconstitucionalidade foi proposta por uma entidade sindical, Confederação Nacional do Transporte - CNT, com fundamento nos artigos 102, I, "a" e “p”, e 103, IX, da Constituição Federal, e no artigo 2º IX, da Lei 9.868/1999, visando à declaração, sem redução de texto, de inconstitucionalidade da aplicação do artigo 4 , I, "a", "b", "c" e "d", da Lei 10.640/2003. Refere-se à suplementação de crédito para reforço de dotações orçamentárias vinculadas aos recursos da CIDE-COMBUSTÍVEIS, conformando aquele preceito de lei ao artigo $177, \S 4^{\circ}$, II, da Constituição.

$\mathrm{O}$ objetivo da ADI seria proteger recursos da CIDE-Combustíveis vinculados no artigo $177, \S 4^{\circ}$, II, da Constituição Federal:

$\S 4^{\circ}$ A lei que instituir contribuição de intervenção no domínio econômico relativa às atividades de importação ou comercialização de petróleo e seus derivados, gás natural e seus derivados e álcool combustível deverá atender aos seguintes requisitos:

${ }^{431}$ STF. ADI de no 2.925. Rel. Min. Ellen Gracie. Publicado no DJ de 4.3.2005. 
(...)

II - os recursos arrecadados serão destinados:

a) ao pagamento de subsídios a preços ou transporte de álcool combustível, gás natural e seus derivados e derivados de petróleo;

b) ao financiamento de projetos ambientais relacionados com a indústria do petróleo e do gás;

c) ao financiamento de programas de infra-estrutura de transportes.

A entidade autora alegou que esse dispositivo constitucional criaria duas obrigações para o poder público no momento da formação da lei orçamentária: a) haveria um limite externo para as despesas, ou seja, nenhum montante arrecadado pode ser aplicado fora da destinação imposta no inciso II do $\S 4^{\circ}$ do artigo 177 da Constituição; e b) também um limite interno, no qual nenhuma das três destinações poderia ficar sem receber recurso oriundo da CIDE-Combustíveis.

Além disso, a Lei Orçamentária Anual de 2003, Lei 10.640/2003, teria disposto a alocação desses recursos vinculados em diversos grupos de despesa: pessoal e encargos sociais; juros e encargos da dívida; outras despesas correntes; investimentos; inversões financeiras; amortização da dívida e reserva de contingência.

Quanto à admissibilidade do recurso, a autora buscou afastar a jurisprudência da impossibilidade de controle de normas de efeitos concretos com que eram taxadas as leis orçamentárias, afirmando: "Desde já, é bom salientar, com tintas fortes e indeléveis, que não é essa destinação ou alocação de recursos, isto é, essa fixação de despesas que se pretende submeter a controle de constitucionalidade. Como se verá adiante, os dispositivos da LOA que a autora quer ver interpretados conforme a Constituição são de conteúdo eminentemente normativo e se inserem entre as normas gerais sobre abertura de crédito suplementar, isto é, as regras de migração de recursos de uma unidade orçamentária para outra ou de subtítulos dentro da mesma unidade orçamentária”.

O seguinte dispositivo fora atacado na ADI:

Art. $4^{\circ}$ Fica o Poder Executivo autorizado a abrir créditos suplementares, observados os limites e condições estabelecidos neste artigo e desde que demonstrada, em anexo específico do decreto de abertura, a compatibilidade das alterações promovidas na programação orçamentária com a meta de resultado primário estabelecida no Anexo de Metas Fiscais da Lei de Diretrizes Orçamentárias 2003, para suplementação de dotações consignadas:

I - a cada subtítulo, até o limite de dez por cento do respectivo valor, mediante a utilização de recursos provenientes de:

a) anulação parcial de dotações, limitada a dez por cento do valor do subtítulo objeto da anulação, ressalvado o disposto no $§ 2^{\circ}$ deste artigo; 
b) reserva de contingência, inclusive de fundos e de órgãos e entidades das Administrações direta e indireta, observado o disposto no parágrafo único do art. $8^{\circ}$ da Lei de Responsabilidade Fiscal, e no $\S$ $6^{\circ}$ deste artigo;

c) excesso de arrecadação de receitas diretamente arrecadadas, desde que para alocação nos mesmos subtítulos em que os recursos dessas fontes foram originalmente programados, observado o disposto no parágrafo único do art. $8^{\circ}$ da Lei de Responsabilidade Fiscal; e

d) até dez por cento do excesso de arrecadação;

A argumentação desenvolvida pretende demonstrar que a norma atacada não se amolda à jurisprudência dominante da Corte, da impossibilidade de análise de normas de efeitos concretos, explorando o entendimento de que a lei orçamentária possuiria uma natureza híbrida, isto é, compondo normas de efeitos concretos e normas abstratas, passíveis de controle:

Esse entendimento não se aplica à presente ação direta, como se verá adiante. Antes, é necessário tecer rápidas considerações sobre a natureza híbrida da lei orçamentária para que não se oponham, já a esta altura, óbices quanto à possibilidade jurídica do pedido deduzido na presente ação.

E faz a distinção entre duas realidades normativas:

“a previsão de receita e a fixação da despesa enquanto indicação numérica de montantes que compõem as diversas dotações, constantes dos Suplementos anexos à Lei, de que são exemplos os diversos programas de trabalho com as respectivas indicações de fonte de receita; e

As normas jurídicas que conferem competência e ao mesmo tempo disciplinam a movimentação intra-orçamentária de recursos, constantes do corpo da lei".

A petição inicial não buscava desconstituir a jurisprudência dominante do STF de não conhecer ações no controle principal com normas concretas, mas tão só demonstrar a sua não adequação ao caso. Isso fica evidente quando complementa:

No primeiro sentido (mera indicação numérica das receitas e dos montantes de recursos alocados a cada programa, categoria de despesa, etc.), estamos perante ato político-administrativo de efeito concreto que não tem natureza normativa e que, portanto, não pode ser objeto de ação direta de inconstitucionalidade. 
Apenas a norma questionada na ADI, nos dizeres da petição inicial, seria uma norma de estrutura, que regularia a produção de outras normas, estas de efeito concreto, portanto, excepcionalmente passível de controle de constitucionalidade em razão da abstração da norma atacada.

É citada a decisão na ADI 2.100, que tratou do controle abstrato da LDO do estado do Rio Grande do Sul no ano de 2000. Tal decisão já havia reconhecido a possibilidade de normas gerais e abstratas serem estabelecidas por leis orçamentárias, mas naquele caso específico ainda se trataria de norma concreta. Cogita-se ainda, no mesmo sentido, a decisão na ADI 2.057, que também questiona uma LDO, do estado do Amapá, em que se afirmou: "constitui ato de natureza concreta a emenda parlamentar que encerra tão-somente destinação de percentuais orçamentários, visto que destituída de qualquer carga de abstração e de enunciado normativo". Tais decisões teriam averiguado a possibilidade de controle de constitucionalidade de leis orçamentárias, sem que no caso analisado efetivamente fossem questionadas normas de caráter abstrato.

A autora da ação alega em sua peça que o dispositivo atacado seria inconstitucional apenas em relação à abertura de créditos suplementares para reforço de dotações da CIDE, ou seja, a aplicação de até $10 \%$ em outras destinações dos recursos da CIDE autorizada pelo artigo $4^{\circ}$ da lei ofenderia a disposição constitucional que taxativamente elenca finalidades específicas:

\begin{abstract}
Inconstitucional a aplicação da lei para anular dotações já vinculadas aos recursos da CIDE-COMBUSTÍVEIS ("a"), para remanejar os recursos que vierem a compor a reserva de contingência dessa Contribuição ("b") ou para aproveitar o excesso de arrecadação da CIDE-COMBUSTÍVEIS ("c" e "d"), repita-se, para fins de suplementação de outras dotações que não aquelas vinculadas pelo artigo 177, $\S 4^{\circ}$, II da CF.(Grifos no original)
\end{abstract}

A petição inicial parece não apenas fundar-se em aspectos puramente deontológicos, especialmente quando afirma que "a presente ação independe da confirmação da estimativa de arrecadação, que acima foi retratada a título meramente ilustrativo". Isto é, independe para a caracterização da (in)validade da norma qualquer efeito posterior ou mesmo a concretização dos fatos descritos na norma impugnada.

É alegado na petição ainda, com base em José Afonso da Silva, que as ADIs serviriam para proteger a supremacia da Constituição e que esta "não restará preservada, 
data venia, se o art. 4, I, alíneas "a" a "d", da Lei 10.640/2003 não tiver seu âmbito normativo glosado por esta Corte em sede de declaracão parcial de inconstitucionalidade sem reducão de texto". Faz-se, dessa forma, o pedido de declaração de inconstitucionalidade sem redução de texto a fim de que a possibilidade de remanejamento até $10 \%$ continue válida para as outras hipóteses e seja declarada inválida apenas para a CIDE.

Por outro lado, o argumento central do pedido de Medida Cautelar é consequencialista, porquanto reconhece a dificuldade do Judiciário em julgar causas orçamentárias dentro do prazo de vigência das leis: "É certo, ainda, que o julgamento meritório da presente ação direta, diante da assoberbada pauta deste Supremo Tribunal, tem poucas chances de ocorrer antes do final da execução orçamentária, quando já terá a norma impugnada exaurida totalmente sua eficácia". E acertadamente o faz. Em outro trabalho $^{432}$ dissertamos sobre a vigência das leis orçamentárias e a sua relação com a ineficácia do seu controle judicial. Isto é, por serem vinculadas ao princípio da periodicidade, as leis orçamentárias tem seu controle prejudicado muitas vezes pela demora natural do Judiciário ao analisar tais questões.

Tanto a Advocacia-Geral da União quanto a Procuradoria-Geral da República manifestaram-se pelo não conhecimento e improcedência do pedido e da medida cautelar.

Concluindo o relatório, a Ministra Ellen Gracie passa a compor os argumentos para a decisão. Inicia afirmando que "a tese sustentada fundamenta-se na necessidade da definição de uma interpretação constitucionalmente válida das espécies de abertura de crédito suplementar" dispostas no dispositivo atacado. Mas, de início, dispõe que se trata de norma de efeito concreto, impassível de controle por ADI. E conclui pela falta dos requisitos de abstração e generalidade necessários à fiscalização do controle de constitucionalidade pela via da ação direta.

Num trecho de seu voto, a Ministra Gracie cogita as repercussões futuras no caso de acolhimento da tese da autora, votando pela inadmissibilidade da ADI:

o acolhimento da pretensão da requerente equivaleria ao reconhecimento de uma incompatibilidade entre contribuição - espécie tributária caracterizada pela finalidade de sua instituição e não pela destinação da respectiva cobrança - e a sistemática da abertura de créditos suplementares, destinados ao reforço das dotações orçamentárias que se revelaram insuficientes durante o exercício financeiro. Entretanto, conforme ressaltado pelo Chefe do Ministério Público Federal, o art. 165,

${ }^{432}$ CHRISTOPOUlOS, Basile. Despesa Pública: estrutura, função e controle judicial. Maceió: Edufal, 2011, p. 164 e seguintes. 
$\S 8^{\circ}$ da CF não parece transparecer tal incompatibilidade ao permitir, excepcionalmente, porém sem distinção de receitas, a abertura de créditos suplementares no orçamento anual da União. Ressalte-se que a limitação de $10 \%$ do respectivo valor a ser suplementado exprime, exatamente, o sentido de exceção conferido pela Carta Magna à possibilidade de abertura dos créditos suplementares.

O Ministro Marco Aurélio inicia seu voto divergindo do proferido pela relatora, com argumento eminentemente consequencialista:

\begin{abstract}
Quando o Tribunal proclamou não convir o controle concentrado relativamente à lei orçamentária, fê-lo a partir da premissa de que esta teria ficado no âmbito da opção política. Aqui, não é isso o que ocorre. Argumenta-se que se acabou por lançar mão, muito embora de forma limitada, de recursos que a própria Carta Federal revela com destinação específica. Busca-se, justamente, a guarda da Constituição pelo Supremo Tribunal Federal, no que a lei orçamentária estaria a conflitar, de modo frontal, com texto nela contido, mais precisamente com o disposto no artigo $177, \S 4^{\circ}$. Se entendermos caber a generalização, afastando por completo a possibilidade do controle concentrado, desde que o ato impugnado seja lei orçamentária, terminaremos por colocar a lei orçamentária acima da Carta da República. Por isso, a meu ver, há que se distinguir caso a caso. (Grifo nosso)
\end{abstract}

O Ministro Gilmar Mendes também inaugura o seu voto com um argumento fundado nas consequências jurídicas da decisão ainda no primeiro parágrafo. Primeiramente ele afirma que discorda da jurisprudência dominante do STF que recai sobre o caso, e acrescenta que "poderemos chegar a distorções significativas, a partir dessa perspectiva". O Ministro defende que a jurisprudência da Corte poderia levar a distorções caso não fosse revista naquele caso, colocando, pois, as consequências novamente no centro da argumentação desenvolvida e da razão para julgar aquele caso de forma diferente.

No mesmo sentido, o Ministro Carlos Ayres Britto aduz que a lei orçamentária seria a mais importante, abaixo da Constituição, e que "imunizar a lei orçamentária contra o controle abstrato, acho um pouco temerário, também, ou seja, vamos blindar a lei orçamentária contra o controle objetivo de constitucionalidade”.

O Ministro Sepúlveda Pertence afirma que a consequência jurídica para o não conhecimento da ação seria a "autorização para, durante um ano, alterar a destinação dada a determinado tributo, a CIDE, pela própria Constituição". E o Ministro Marco Aurélio complementa: "Seria tornar a nossa Carta da República flexível, passível de modificação por uma lei orçamentária”. 
Em seguida o Ministro Sepúlveda Pertence faz uma interessante alusão à não previsão das consequências num caso semelhante anterior: "Estou vendo um dos precedentes: autorização para destinar parte da arrecadação da CPMF a cobrir débitos do Ministério da Saúde com o FAT - não conhecemos da ADIn (o que me dá um certo remorso, diante do que veio a suceder posteriormente)".

“É preciso, pelo menos, fazer algum distinguo, senão estamos dando uma carta de indenidade a toda a legislação orçamentária”, afirma o Ministro Sepúlveda Pertence, seguido pelo Ministro Gilmar Mendes: “E poderá até estimular, no futuro, a se colocar na lei orçamentária", referindo-se ao problema das caudas orçamentárias, tratado no tópico 1.1.3.

O Ministro Marco Aurélio ressalta a noção de universalidade exposta por MacCormick:

Todos estamos de acordo com a supremacia da Carta da República. Agora, se existe tanta dúvida, a ponto de se ajuizar a ação direta de inconstitucionalidade, evidentemente, precisamos partir, a fim de evitar controvérsias futuras, para a interpretação conforme e proclamar que não pode haver a utilização, como crédito suplementar, dessa rubrica que tem destinação peremptória, categórica, em texto exaustivo na Carta da República.

Enfrentando a questão de mérito, a relatora, Ministra Ellen Gracie, afirma que não haveria a possibilidade de desvio das receitas da CIDE para outras finalidades não referidas na Constituição; é que os créditos suplementares poderiam ser propostos, "no limite das disponibilidades dos recursos, mediante a apresentação de justificativa da necessidade e o envio de projeto de lei ao Poder Legislativo, que então concederá ou negará a autorização legislativa solicitada". Deixa decerto de levar em consideração que o caso em tela é justamente sobre uma margem de remanejamento independente de autorização legislativa, e que mesmo a lei não poderia fixar outras finalidades diversas das postas na Carta. Afirma ainda que os recursos não poderiam ser desviados de sua finalidade em razão do disposto no artigo $8^{\circ}$, parágrafo único, da Lei de Responsabilidade Fiscal. Conclui seu voto com a seguinte redação:

Por essas razões, especialmente pela natureza mandamental que entrevejo colocada nesta ação, eficácia que não se encontra na ação direta de inconstitucionalidade, por este caráter - digamos - preventivo de tentar evitar que o Governo dê "um mau passo" na questão da aplicação desses recursos, julgo improcedente o pedido formulado nesta ação direta de inconstitucionalidade. 
A Ministra Ellen Gracie entende que a procedência do pedido levaria a "uma ordem que o Judiciário dê ao Executivo para que gaste o valor ' $\mathrm{x}$ ' em tal finalidade".

O Ministro Nelson Jobim ressalta o argumento anterior, levantado pela Ministra Ellen Gracie, de que o artigo $8^{\circ}$ da Lei de Responsabilidade Fiscal impediria a desvinculação das receitas da CIDE de qualquer forma, sendo desnecessária a declaração da interpretação conforme neste caso.

A argumentação do Ministro Carlos Velloso num dado momento do acórdão parece formular argumentação se não consequencialista, ao menos extrajurídica, embora de menor importância na formulação do dispositivo final, quando afirma:

Como cidadão, penso que o Governo deveria, de há muito, estar gastando a CIDE na manutenção das nossas rodovias, que estão acabando. Se o Governo deixar que a nossa teia rodoviária se acabe - e parece que o Governo não liga para o assunto, pois as estradas estão cada vez mais estragadas - vai ter que gastar muito mais. É preciso pensar na segurança das pessoas que utilizam as nossas estradas, é preciso pensar no transporte de cargas, é preciso compreender que rodovias estragadas aumentam os preços dos fretes, assim aumentam os preços dos gêneros de primeira necessidade e o sacrificado, em consequência, é o povo.

O Ministro Gilmar Mendes conclui sobre considerações de oportunidade e conveniência do julgamento:

\footnotetext{
É até uma infelicidade que tenhamos de debater esse tema, e a Ministra Ellen Gracie trouxe isso, exatamente, por revelação de responsabilidade, não deixar que isso entrasse no exercício findo e, depois, tivéssemos, aí, a questão da discussão sobre os efeitos e tudo mais, e o eventual exaurimento da eficácia da norma.
}

Afirma que o melhor seria a realização de uma audiência pública ou a designação de um debate entre experts. E conclui na mesma linha já citada no acórdão de Neil MacCormick sobre universalização: "Acho que era um típico caso para que pudéssemos analisar a repercussão não só nesse caso, mas em outros”.

Ministros vencedores: Maurício Corrêa, Carlos Velloso, Marco Aurélio, Gilmar Mendes, Cezar Peluso, Carlos Britto. Ministros vencidos: Ellen Gracie, Joaquim Barbosa, Nelson Jobim, Sepúlveda Pertence. Ministro ausente: Celso de Mello 


\section{Argumentos Deontológicos (AD)}

O argumento deontológico por excelência, recorrente nos debates da matéria, é justamente sobre a natureza das leis orçamentárias, nesse caso, compondo o ratio decidendi. $\mathrm{O}$ argumento da generalidade e abstração já foi exposto com suas premissas nas análises dos acórdãos anteriores.

\section{Argumentos Consequencialistas Jurídicos (ACJ)}

A razão do conhecimento da ação foi construída, como visto na descrição do Acórdão, com base em argumento consequencialista. Diversos ministros especulam sob o mesmo fundamento, de que "imunizar a lei orçamentária contra o controle abstrato, acho um pouco temerário, também, ou seja, vamos blindar a lei orçamentária contra o controle objetivo de constitucionalidade"; "senão, estamos dando uma carta de indenidade a toda a legislação orçamentária"; "E poderá até estimular, no futuro, a se colocar na lei orçamentária". E que seria a "autorização para, durante um ano, alterar a destinação dada a determinado tributo, a CIDE, pela própria Constituição"; "Seria tornar a nossa Carta da República flexível, passível de modificação por uma lei orçamentária”.

É possível perceber a força argumentativa (ratio decidendi) que esse argumento produziu nos ministros do STF, quando vários deles se manifestaram no mesmo sentido, especulando negativamente sobre as repercussões de um possível não conhecimento da ação.

São pressupostos desse argumento: a) todas as normas devem sofrer controle de constitucionalidade, sob pena de ofensa à supremacia constitucional; b) o controle incidental não é suficiente para controlar a constitucionalidade de leis e normas orçamentárias; c) as normas orçamentárias não podem ficar sem controle de constitucionalidade; d) as normas orçamentárias devem ser constrangidas ao controle principal; e) a mensagem jurídica que seria passada pela decisão seria a de que as leis orçamentárias estariam acima da Constituição; f) as leis orçamentárias apenas devem dispor o conteúdo eleito constitucionalmente; g) uma consequência nefasta do não conhecimento da ADI seria a inclusão de normas não orçamentárias nas leis.

Veja-se que o ministro, quando afirma que a lei orçamentária poderia modificar a Constituição, não pretende defender que no caso de não conhecimento as leis orçamentárias efetivamente o poderiam fazer. É um argumento tipicamente formado por 
um entimema, entretanto destinado mais ao convencimento do que propriamente a uma descrição da verdade sobre o ordenamento jurídico.

Outro argumento de cunho consequencialista, menos importante que o primeiro, por não influenciar decisivamente a decisão final proferida (obiter dictum), foi o expresso da seguinte forma: "Estou vendo um dos precedentes: autorização para destinar parte da arrecadação da CPMF a cobrir débitos do Ministério da Saúde com o FAT - não conhecemos da ADIn (o que me dá um certo remorso, diante do que veio a suceder posteriormente)". Alega-se que os conflitos atuais poderiam ter sido resolvidos caso o Supremo Tribunal Federal tivesse decidido questões semelhantes no passado, formando um precedente: "Acho que era um típico caso para que pudéssemos analisar a repercussão não só nesse caso, mas em outros".

No mesmo sentido, mas prevendo as consequências que essa decisão pode ter positivamente no futuro, alegou-se que "precisamos partir, a fim de evitar controvérsias futuras, para a interpretação conforme e proclamar que não pode haver a utilização, como crédito suplementar, dessa rubrica que tem destinação peremptória, categórica, em texto exaustivo na Carta da República".

São premissas desses argumentos conexos: a) as ações baseiam-se em precedentes, especialmente do Supremo Tribunal Federal; b) a decisão tomada anteriormente foi equivocada; c) está-se diante de um caso semelhante; d) a ação ora examinada resultou de conflitos evitáveis.

Outro argumento consequencialista, este menos importante, portanto, obiter dictum, foi produzido sobre a oportunidade e conveniência do julgamento, considerando que a norma poderia perder sua eficácia caso o julgamento não tivesse se dado naquele momento: "não deixar que isso entrasse no exercício findo e, depois, tivéssemos, aí, a questão da discussão sobre os efeitos e tudo mais, e o eventual exaurimento da eficácia da norma".

O último argumento consequencialista encontrado, também obiter dictum (voto vencido), explicita a inutilidade da declaração de inconstitucionalidade, uma vez que o artigo $8^{\circ}$ da Lei de Responsabilidade Fiscal - LRF impediria de qualquer forma a desvinculação das receitas da CIDE, sendo desnecessária a declaração da interpretação conforme neste caso.

As premissas são: a) a declaração de inconstitucionalidade deve ser útil; b) quando uma norma infraconstitucional, no caso uma Lei Complementar, dispõe o mesmo 
conteúdo constitucional, seria indiferente contrariar o texto constitucional; c) as disposições da LRF impediriam a eficácia de normas contrárias à Constituição.

Constatam-se claramente vários problemas nas premissas adotadas nesse argumento, de forma que ele não parece plausível ou convincente.

\section{Argumentos Consequencialistas Extrajurídicos (ACE)}

O único argumento consequencialista extrajurídico que se pôde observar na decisão foi o proferido pelo Ministro Carlos Velloso, embora de menor importância na formulação do dispositivo final, quando afirma:

Como cidadão, penso que o Governo deveria, de há muito, estar gastando a CIDE na manutenção das nossas rodovias, que estão acabando. Se o Governo deixar que a nossa teia rodoviária se acabe - e parece que o Governo não liga para o assunto, pois as estradas estão cada vez mais estragadas - vai ter que gastar muito mais. É preciso pensar na segurança das pessoas que utilizam as nossas estradas, é preciso pensar no transporte de cargas, é preciso compreender que rodovias estragadas aumentam os preços dos fretes, assim aumentam os preços dos gêneros de primeira necessidade e o sacrificado, em consequência, é o povo.

O Ministro nessa passagem relaciona o desvio de recursos da CIDE à má prestação de serviços públicos para os quais o tributo deveria efetivamente ser destinado. A alegação que parece ser desenvolvida é a de que os desvios de recursos dos tributos devem ser evitados.

As premissas do argumento são: a) a CIDE deve ser destinada para a área dos transportes; b) há, em análise, um caso em que ocorre um desvio de recursos da CIDE para outras áreas; c) constata-se falta de recursos para a área de transportes, uma vez que há deficiência na prestação dos serviços.

\section{Análise da Composição de Argumentos}

Um grande marco do controle de constitucionalidade abstrato ocorreu no julgamento da ADI 2925-8, cujo conhecimento se deu com base em argumentos consequencialistas. Apesar de não ser a primeira decisão nesse sentido, foi o precedente estabelecido pelo Supremo Tribunal Federal que modificou o entendimento sobre o assunto. 
É importante observar que nesse Acórdão o preponderante para conhecer o mérito do pedido não foi uma argumentação dedutivista, calcada no reconhecimento de um princípio incidente sobre o caso, que seria o da supremacia da Constituição, senão uma argumentação voltada aos efeitos danosos que uma decisão no sentido contrário poderia acarretar. Portanto, o argumento claramente predominante para quem lê o acórdão é tipicamente consequencialista do ponto de vista jurídico, sendo utilizado por diversos ministros.

O Ministro Gilmar Mendes, não mais no julgamento, mas como doutrinador na obra "Controle Abstrato de Constitucionalidade: ADI, ADC e ADO", defende a mesma visão adotada na ADI 2.925-8:

A extensão dessa jurisprudência, desenvolvida para afastar do controle abstrato de normas os atos administrativos de efeito concreto, chamadas leis formais, suscita, sem dúvida, alguma insegurança, porque coloca a salvo do controle de constitucionalidade um sem-número de leis. ${ }^{433}$

E o doutrinador Gilmar Mendes vai além, ao defender que:

Outra há de ser, todavia, a interpretação, se se cuida de atos editados sob a forma de lei. Nesse caso, houve por bem o constituinte não distinguir entre leis dotadas de generalidade e aqueloutras, conformadas sem o atributo da generalidade e abstração.

(...) não me parece admissível que o intérprete debilite essa garantia da Constituição, isentando um número elevado de atos aprovados sob a forma de lei do controle abstrato de normas e, muito provavelmente, de qualquer forma de controle. ${ }^{434}$

Vê-se que a abundância de argumentos consequencialistas se concentra na análise da admissibilidade da ADI, mais do que propriamente no mérito da questão, como se verá. A questão parece bem clara na decisão. A decisão do não conhecimento da ação levaria a consequências indesejáveis para o ordenamento jurídico. Isto é, decidir seguindo a jurisprudência tradicional do STF que as leis orçamentárias não são passíveis do controle de constitucionalidade seria estabelecer juridicamente graves obstáculos a qualquer tipo de análise de sua constitucionalidade, transformando as leis orçamentárias em instrumentos normativos incontroláveis.

\footnotetext{
${ }^{433}$ MENDES, Gilmar. Controle Abstrato de Constitucionalidade: ADI, ADC e ADO: comentários à Lei n. 9.868/99. São Paulo: Saraiva, 2012, p. 137.

${ }^{434}$ Idem, Ibdem.
} 
Outro ponto relevante do julgado foi em relação à natureza das leis e normas orçamentárias. A Ministra Ellen Gracie, relatora vencida, dispõe em seu voto sobre a generalidade da norma atacada, cometendo uma impropriedade na análise do conceito de generalidade e abstração na teoria do pensador italiano:

\begin{abstract}
mesmo se considerando 'norma de estrutura' no dizer de Bobbio, citado na inicial, ou 'regra matriz de todas as movimentações intraorçamentárias de recursos', deve incidir sobre as situações abrangidas pela lei e tem, portanto, destinação específica, inviabilizando o controle concentrado.
\end{abstract}

A ministra Ellen Gracie falhou ao considerar que seria requisito para a abstração de uma norma a incidência desta em outras situações fora da lei orçamentária em questão. Na verdade, a abstração, como visto no capítulo anterior, depende apenas da possibilidade de múltiplas incidências que não se esgotam parcial ou totalmente em cada uma delas. Isto é, se a cada incidência da norma esta se esgota parcial ou totalmente, haveria uma norma de efeitos concretos; se esta não se esgota, há uma norma abstrata.

Prescreve acertadamente no mesmo sentido o Ministro Carlos Ayres Britto que a abstratividade implica uma renovação não esgotável, ainda que limitada por um ano, entre a hipótese de incidência da norma e a sua consequência.

\title{
3.2.6 ADI 4.048/DF: crédito extraordinário por Medida Provisória ${ }^{435}$
}

\section{Contexto do Acórdão e Dispositivos Atacados}

A Ação Direta de Inconstitucionalidade - ADI 4048-1/DF foi proposta com pedido de medida cautelar pelo Partido da Social Democracia Brasileira - PSDB, com o objetivo de obter declaração de inconstitucionalidade da Medida Provisória $\mathrm{n}^{\mathbf{0}} 405$, de 18.12.2007, que abriu créditos extraordinários no âmbito da União.

A petição inicial ataca o artigo $167, \S 3^{\circ}$, da Constituição Federal, que trata sobre créditos extraordinários, dispondo os requisitos da imprevisibilidade e urgência, além das hipóteses de guerra, comoção interna e calamidade pública. Cita também o artigo 62, $\S 1^{\circ}, \mathrm{I}, d$, da Constituição Federal, que trata dos requisitos das Medidas Provisórias e que

${ }^{435}$ STF. ADI de no 4.048. Rel. Min. Gilmar Mendes. Publicado no DJ de 21.8.2008. 
exclui as normas e leis orçamentárias, com exceção dos créditos extraordinários, da sua competência material.

Expõe-se sob forma de doutrina a citação do livro do Ministro da Corte Gilmar Ferreira Mendes, que lança mão de um argumento consequencialista para a falta de controle de constitucionalidade das leis orçamentárias, criticando a própria jurisprudência do STF:

A extensão dessa jurisprudência, desenvolvida para afastar do controle abstrato de normas os atos administrativos de efeito concreto, às chamadas leis formais suscita, sem dúvida, alguma insegurança, porque coloca a salvo do controle de constitucionalidade um sem-número de leis.

Segundo a peça inicial, não se estaria "a discutir o conteúdo de um crédito extraordinário em si mesmo, mas, sim, o real enquadramento de um determinado crédito na categoria de 'extraordinário'". E completa com um raciocínio consequencialista, quando afirma que:

Do contrário, medidas provisórias sobre créditos extraordinários seriam mais fortes do que leis ordinárias, porque escapariam ao controle de constitucionalidade, bem assim ficaria destituída de sentido a norma constitucional - que é excepcional - sobre a abertura de crédito extraordinário.

A petição inicial segue citando o Ministro Gilmar Mendes em seu livro "Jurisdição Constitucional", com o argumento de que o constituinte não haveria distinguido leis dotadas de generalidade e abstração e outras sem tais atributos: "Essas leis formais decorrem ou da vontade do legislador ou da vontade do próprio constituinte, que exige que determinados atos, ainda que de efeito concreto, sejam editados sob a forma de lei”, afirma o Ministro citado na peça. E conclui:

Ora, se a Constituição submete a lei ao processo de controle abstrato, até por ser este o meio próprio de inovação na ordem jurídica e o instrumento adequado de concretização da ordem constitucional, não parece admissível que o intérprete debilite essa garantia da Constituição, isentando um número elevado de atos aprovados sob a forma de lei do controle abstrato de normas e, muito provavelmente, de qualquer forma de controle. É que muitos desses atos, por não envolverem situações subjetivas, dificilmente poderão ser submetidas a um controle de legitimidade no âmbito da jurisdição ordinária. 
Reforça, ainda, o argumento consequencialista ao afirmar que não admitir a ADI para declarar a inadequação de despesas como créditos extraordinários seria "criar espaço de ilegitimidade (de inconstitucionalidade) não passível de controle jurisdicional”.

Foi pedida a concessão de medida cautelar, suspendendo a eficácia da medida provisória $\mathrm{n}^{\circ} 405$ e, ao fim, a declaração de sua inconstitucionalidade.

Quando instada a prestar informações, a Advocacia-Geral da União - AGU reafirmou a jurisprudência do STF no sentido de não conhecer em sede de controle abstrato questões orçamentárias, deixando de tratar, no entanto, a ADI 2.925, que assinalou uma mudança de paradigma na jurisprudência. Inclusive a petição inicial, proposta pelo PSDB, também não tratou da questão, explorando-a minimamente. Talvez porque esta peça tenha caminhado num sentido diferente e mais ousado do que o proposto na petição inicial da ADI 2.925 e nela decidido.

A Ministra Ellen Gracie faz ampla explanação sobre a jurisprudência do STF em não analisar leis de efeitos concretos e como o caso em análise seria diverso da ADI 2.925 , pois o STF reconheceu abstração na norma atacada, o que não estaria presente no caso.

Um dos primeiros argumentos desenvolvidos pelo relator, Ministro Gilmar Mendes, segue a linha dos argumentos citados na petição inicial, com base em seu livro doutrinário, e tem natureza essencialmente consequencialista: "A extensão da jurisprudência, desenvolvida para afastar do controle abstrato de normas os atos administrativos de efeito concreto, às chamadas leis formais suscita, sem dúvida, alguma insegurança, porque coloca a salvo do controle de constitucionalidade um sem-número de leis".

O Ministro Gilmar Mendes, relator do Acórdão, afirma que efetivamente não deve haver controle de constitucionalidade de normas de efeito concreto, mas que deveria ser exceção quando tais normas fossem veiculadas sob a forma de lei.

Ora, se a Constituição submete a lei ao processo abstrato, até por ser este o meio próprio de inovação na ordem jurídica e o instrumento adequado de concretização da ordem constitucional, não parece admissível que o intérprete debilite essa garantia da Constituição, isentando um número elevado de atos aprovados sob a forma de lei do controle abstrato de normas e, muito provavelmente, de qualquer forma de controle. É que muitos desses atos, por não envolverem situações subjetivas, dificilmente poderão ser submetidos a um controle de legitimidade no âmbito da jurisdição ordinária. 
Interessante a justificativa utilizada pelo Ministro para o argumento acima exposto:

Ressalte-se que não se vislumbram razões de índole lógica ou jurídica contra a aferição da legitimidade das leis formais no controle abstrato de normas, até porque abstrato - isto é, não vinculado ao caso concreto - há de ser o processo e não o ato legislativo submetido ao controle de constitucionalidade.

Pode-se ver nessa citação do ora doutrinador Gilmar Mendes que há argumentos consequencialistas e deontológicos na defesa da questão, mais propriamente da necessidade de controle da medida provisória em matéria orçamentária por ADI. Deontológico quando afirma que a Constituição submeteu indistintamente todas as leis ao controle de constitucionalidade abstrato e que não caberia a nenhuma lei ordinária restringir tal controle. Consequencialista quando afirma que em caso de impossibilidade de controle de constitucionalidade por meio de ADI, dificilmente elas poderiam ser objeto de controle por outra via, o que levaria, como consequência, a um espaço de perigo à supremacia constitucional.

O relator também argumenta que no plano da teoria do direito seria possível apresentar uma norma tanto de forma genérica e abstrata quanto de efeito concreto. $\mathrm{E}$ defende que "a Corte não pode se furtar à análise do tema posto nesta ação direta. Há uma questão constitucional, de inegável relevância jurídica e política, que deve ser analisada a fundo".

No fim do relatório formula ainda um argumento no seguinte sentido: “A meu ver, essa nova orientação é mais adequada porque, ao permitir o controle de legitimidade no âmbito da legislação ordinária, garante a efetiva concretização da ordem constitucional”.

Passando a analisar o mérito, o relator aborda a dificuldade para estabelecer limites aos conteúdos semânticos das expressões contidas na Constituição e que põem limites ao caso, como "guerra", “comoção interna", "calamidade pública" e "imprevisibilidade e urgência".

E passa a analisar os fatos que devem se enquadrar nesses conteúdos, por meio da exposição de motivos da Medida Provisória 405/2007. Nela constam informações sobre as finalidades das despesas autorizadas pela MP.

Havia diversas despesas para diversos órgãos, e de diversos poderes. Destacam-se entre elas: 
No caso da Presidência da República, os recursos atenderão a despesas emergenciais, referentes ao contrato de gestão com a Associação de Comunicação Educativa Roquete Pinto - ACERP, de forma a promover as ações necessárias à implantação da TV Digital no Brasil.

(...)

No âmbito do Ministério do Esporte, o crédito possibilitará a implantação do centro de treinamento em canoagem "slalom", o qual beneficiará o País com uma instalação olímpica do mais alto padrão internacional, permitindo melhorar a performance dos nossos competidores; a concessão de cerca de 1.344 bolsas, ou seja, remuneração mensal a título de apoio aos atletas de alto rendimento.

(...)

No que tange ao Ministério da Integração Nacional, os recursos permitirão o apoio a projetos de infra-estrutura e de desenvolvimento sustentável local integrado em diversos Municípios carentes do País, com o propósito de fomentar o desenvolvimento socioeconômico dessas localidades com vistas à geração de emprego e renda para a população.

Conclui o relator que os créditos abertos seriam destinados a prover despesas correntes, não qualificadas pela imprevisibilidade ou pela urgência, requisitos de toda MP. Cita inclusive algumas exceções, de despesas que poderiam ter sito autorizadas constitucionalmente pelo mecanismo crédito extraordinário/medida provisória.

Em algumas despesas veiculadas pela Medida Provisória, portanto, seria possível reconhecer a relevância dos temas:

São os casos, por exemplo, dos créditos destinados à redução dos riscos de introdução da gripe aviária e de outras doenças exóticas na cadeia avícola brasileira; aqueles destinados às operações de policiamento nas rodovias federais e de investigação, repressão e combate ao crime organizado e para evitar a invasão de terras indígenas, assim como para solver a grave situação dos sistemas penitenciários com superpopulação carcerária; os créditos destinados ao aporte imediato de recursos extras para o pagamento de benefícios aos agricultores familiares do semi-árido que tiveram perdas na última safra; e, enfim, os créditos destinados a evitar a suspensão dos serviços de vigilância territorial.

No entanto, segundo o Relator, faltariam mesmo a esses casos o requisito da imprevisibilidade, já que a situação de crise ainda não estaria configurada, havendo grande risco ao seu desencadeamento. E conclui que "nenhuma das hipóteses previstas pela medida provisória configura situações de crise imprevisíveis e urgentes, suficientes para a abertura de créditos extraordinários". 
Argumenta também que "impressiona a quantidade elevada de medidas provisórias editadas, no último ano, pelo Presidente da República, para abertura de créditos suplementares ou especiais travestidos de créditos extraordinários". ${ }^{46}$

A Ministra Carmen Lúcia, ao acompanhar o voto, ratifica o argumento consequencialista de que decidir em sentido contrário seria "criar um cavalo de Tróia no sistema de controle de constitucionalidade. Estaríamos lidando com, às vezes, a execução que vem numa lei, e aquilo que é muito maior ficaria inexpugnável”. Aduz o Ministro Gilmar Mendes: "Porque, hoje, temos as leis, por exemplo, que criam autarquias, fundações, autorizam criação de empresas ou mesmo - o Tribunal nunca teve dúvida disso - lei que cria município. Se fôssemos assumir uma posição radical, ficaríamos sem mecanismo de controle". (grifo nosso).

O Ministro Carlos Britto reafirma o argumento do relator, ressaltando a importância da lei orçamentária:

não há lei mais importante para o país, porque a que mais influencia o destino da coletividade, do que esta lei. A lei orçamentária é a lei materialmente mais importante do ordenamento jurídico logo abaixo da Constituição. E deixar essa lei do lado de fora do controle de constitucionalidade, em processos objetivos, parece um contra-senso realmente.

O Ministro Cezar Peluso inaugura a divergência com o argumento deontológico de que a norma analisada nem sequer seria lei formal, mas "ato complexo em que se pede a participação do Legislativo". Seria "simplesmente autorização para a prática de um ato que pede a colaboração do Legislativo". Em contraponto, o Ministro Carlos Britto afirma que estaria sendo consagrada a distinção entre lei formal do Poder Legislativo e ato normativo, e que não seria mais necessária a densidade normativa para que a lei fosse exposta ao controle abstrato de constitucionalidade.

Um argumento interessante é levantado pelo Ministro Joaquim Barbosa, de que a legitimidade para decidir tais questões seria do Congresso Nacional, que já haveria aprovado a Medida Provisória, e que não caberia ao Poder Judiciário, em especial o STF, "substituir o Congresso Nacional em sede de cautelar para rejeitar uma medida provisória que o Congresso já aprovou".

\footnotetext{
436 "Desde o início do ano de 2007, já se podem contar mais de 20 medidas provisórias destinadas à abertura de créditos de duvidosa natureza extraordinária (MP nº 343, 344, 346, 354, 356, 364, 365, 367, 37-, 376, 381, 383, 395, 399, 400, 402, 405, 406, 408, 409, 420 e 423)”. STF. ADI de no 4.048. Rel. Min. Gilmar Mendes. Publicado no DJ de 21.8.2008.
} 
Ainda sobre a questão da legitimidade do Judiciário para se pronunciar sobre a matéria, segundo o Ministro Ricardo Lewandowski, a edição de medida provisória seria um ato complexo, e "mais do que isso, é um ato de governo, que se caracteriza pela ampla discricionariedade. Ou seja, a vontade do Executivo conjugada com a vontade do parlamento só pesa esses critérios de urgência, relevância, imprescindibilidade, impossibilidade de previsão, imprevisibilidade etc. O Judiciário, que é um fiscal, um fator de equilíbrio do relacionamento entre esses dois Poderes eminentemente políticos, a meu juízo, só interfere em momentos excepcionais de teratologia, de abuso, de absoluta irracionalidade".

E conclui o Ministro Peluso que o Judiciário não poderia assumir a responsabilidade sobre tal julgamento, sob pena de ofensa ao princípio da separação dos Poderes, uma vez que constituiria competência do Presidente da República e do Congresso Nacional o exame da "conveniência da abertura, ou não, de um crédito extraordinário":

Recorrendo a critérios pessoais, posso dizer que, em muitos ou na maioria dos casos de medida provisória, se me fosse dado, como agente constitucional, examinar se havia relevância e urgência, diria que não havia. Do mesmo modo, posso até dizer, aqui, que não as há. Só que não me sinto autorizado, pela Constituição, a fazer esse juízo. Não foi atribuído ao Supremo Tribunal Federal dizer se há, ou não, relevância e urgência naqueles outros casos, ou se há relevância e urgência também neste.

Aqui apresenta o Supremo Tribunal Federal justamente a discussão sobre o self-restraint e o ativismo judicial, questionando os limites de atuação do Poder Judiciário em matéria financeira. O Ministro Celso de Mello confirma a preocupação da Corte com o tema: "Tenho observado, ao longo destes quase dezenove anos no Supremo Tribunal Federal, que esta Corte tem se preocupado muito mais com a intangibilidade das competências institucionais do Poder Legislativo do que o próprio Congresso Nacional”.

Partindo para a argumentação de cunho deontológico, o Ministro Marco Aurélio afirma que a cláusula final do $\S 3^{\circ}$ do artigo 167 seria "apenas exemplificativa, na alusão a situações decorrentes de guerra, comoção interna ou calamidade pública”.

Sobre a redação deste artigo, a Ministra Carmen Lúcia elabora uma distinção não muito clara entre imprevisão, imprevisibilidade e imprevidência: imprevisão "são casos que poderiam ser previstos, e não o são; a imprevisibilidade é aquilo que não pode ser cogitado pelo administrador público, porque surge de uma maneira arriscada, fora do 
ordinário"; e imprevidência seria o descumprimento do dever de prever a ocorrência de casos como os citados pelo relator.

Utilizando um argumento consequencialista extrajurídico, a Ministra Ellen Gracie afirma que "A medida provisória em exame é um exemplo flagrante da indispensabilidade da existência de uma fórmula capaz de garantir o prosseguimento das atividades do governo e da prestação dos serviços públicos em momento de 'apagão' legislativo". Acrescenta que seria de conhecimento geral a dificuldade de tramitação do Orçamento de 2008, excedendo o prazo constitucional sem solução.

O Ministro Gilmar Mendes levanta a questão da periodicidade das leis orçamentárias e a necessidade de se analisarem em sede de medida cautelar as questões orçamentárias sob pena de perda do objeto. E formula um argumento consequencialista: "Por isso que, neste caso, me parece que se impõe a discussão em sede de cautelar, porque, realmente, talvez nós nos defrontássemos com uma situação consolidada. Levei realmente em conta esse aspecto".

O então Advogado-Geral da União - AGU, José Antônio Dias Toffoli esclareceu à Corte que os efeitos ainda não haviam se encerrado em razão da existência de restos a pagar, e que a Medida Provisória, apesar de aprovada pelo Legislativo, ainda não teria findo o seu processo legislativo, visto que pendente de sanção ou veto do Presidente da República. ${ }^{437}$

O Ministro Cezar Peluso formula argumento consequencialista fundado da ideia de universalidade defendida por MacCormick, quando afirma que o julgamento deveria ser concluído "com a composição plena da Corte, dada sua importância como leading case".

Em seguida ele menciona especificamente a necessidade de universalidade da decisão, mas negando que o caso em tela possa efetivamente ser aplicado em outras situações referentes a medidas provisórias:

Eu também entendo que o Ministro Joaquim Barbosa tem razão, quando aponta para impossibilidade de, aqui, equipararmos a hipótese com outros casos em que a conversão da medida provisória em lei não elimina necessidade de a Corte reconhecer a eventual inconstitucionalidade de uma e de outra, porque os outros casos em geral, inclusive relativos à Lei de Diretrizes Orçamentárias, têm alguma densidade no sentido de universalidade, de atingir outras situações.

437 Em voto-vista, entregue em data posterior aos primeiros pronunciamentos dos demais Ministros, a Ministra Ellen Gracie relata que um dia após a sessão de 17.4.2008, em 18.4.2008, foi convertida a Medida Provisória e publicada a Lei 11.658/2008. 
O Ministro Celso de Mello afirma que a conversão legislativa da Medida Provisória em lei não teria o condão de expungir os vícios de inconstitucionalidade e que a supremacia da ordem constitucional seria um princípio derivado do caráter rígido de que se revestiriam as normas inscritas no texto fundamental. A vontade e aprovação pelo Parlamento, portanto, não seriam suficientes para superar as inconstitucionalidades apontadas.

Desenvolve ainda um argumento sobre o excesso de medidas provisórias o Ministro Celso de Mello:

Extrema preocupação - confirmada e agravada pelo caso ora em exame - com o excesso de medidas provisórias que os sucessivos Presidentes da República (inclusive o atual Chefe do Poder Executivo da União) têm editado, transformando a prática extraordinária dessa competência normativa primária em exercício ordinário do poder de legislar, com grave comprometimento do postulado constitucional da separação dos poderes.

O Ministro Celso de Mello ressalta em seu voto que a indevida expansão da competência constitucional, a exemplo das medidas provisórias, levaria a uma situação instauradora de concreto desrespeito ao sistema de Poderes limitados. Faz, ainda, uma ampla explanação sobre tal princípio e sobre os perigos de mecanismos como o decreto-lei e a atual medida provisória.

Aduz o Ministro relacionando esse processo de expansão indevida e a supremacia da Constituição:

Uma visão do processo político-institucional, que se recuse a compreender a supremacia da Constituição e que hesite em submeter-se à autoridade normativa de seus preceitos, notadamente daqueles que consubstanciam as cláusulas pétreas - que protegem o núcleo irreformável e a essência mesma do pacto constitucional - é censurável e é preocupante, pois torna evidente que ainda há, na intimidade do Poder, um resíduo de indisfarçável autoritarismo, despojado de qualquer coeficiente de legitimidade ético-jurídica.

E afirma finalmente que a compulsão da competência para editar medidas provisórias teria culminado por provocar "graves distorções no modelo político e gerado sérias disfunções comprometedoras da integridade do princípio da separação dos poderes".

O Ministro Celso de Mello relata que no período compreendido entre a data da promulgação da Constituição Federal em 1988 e a data do julgamento os Presidentes da 
República teriam legislado duas vezes mais do que o Congresso Nacional, tornando instável o ordenamento jurídico brasileiro e deslocando o foco das decisões legislativas.

O Ministro Carlos Britto, na confirmação de seu voto, esclarece a diferenciação de requisitos da medida provisória dos requisitos do crédito extraordinário, que ele chama de "devido processo legal orçamentário", portanto do artigo 62 e do $\S 3^{\circ}$ do artigo 167, e que neste caso:

\begin{abstract}
A Constituição confere ao orçamento uma proteção especialíssima. O orçamento, depois dela própria, a Constituição, é a lei que mais influencia os destinos da coletividade, o quotidiano de todos nós. Então, a Constituição confere ao orçamento um devido processo legal nãocoincidente com aquele do artigo 62.
\end{abstract}

Por fim, em seu voto o Ministro Carlos Britto cogita a inconveniência que poderia se dar com decisão diversa, de possibilitar a obstrução, sobrestamento ou "tramitação de processos no Congresso Nacional, impedindo este de dispor sobre a sua pauta ou sobre a sua própria agenda de trabalho".

Outro argumento consequencialista levantado pelo Ministro Celso de Mello e corroborado pelo relator Gilmar Mendes é que dez por cento do orçamento efetivamente estaria sendo praticado mediante crédito extraordinário, por medida provisória. Isso mostraria o impacto da decisão e também como o caso concreto representaria uma realidade mais ampla e danosa ao sistema jurídico.

O mesmo argumento consequencialista presente da ADI 2.925 é levantado pelo Ministro Gilmar Mendes: "quando assumimos que não podemos fazer esse controle, estamos nos demitindo, criando um bill de indenidade em relação a essas normas como um todo. Por isso me parece insusceptível”.

Foram vencedores os Ministros: Gilmar Mendes, Celso de Mello, Marco Aurélio, Carlos Britto, Carmen Lúcia, Eros Grau. E vencidos: Cezar Peluso, Ricardo Lewandowski, Ellen Gracie, Joaquim Barbosa, Menezes Direito.

\title{
Argumentos Deontológicos (AD)
}

A alegação deontológica utilizada de maior importância para o conhecimento da ação, portanto ratio decidendi na questão, é a de que é possível o controle de constitucionalidade principal sobre atos concretos desde que veiculados por lei formal. Ou 
seja, não seria mais necessária a densidade normativa para que a lei fosse exposta ao controle principal de constitucionalidade.

Esse argumento funda a noção de que o artigo 102, I, a, da Constituição Federal não exige que o conteúdo normativo das leis seja abstrato e genérico para que sofra o controle de constitucionalidade principal.

Um dos ministros, em posição contrária e derrotada (obiter dictum), afirma que a norma analisada nem sequer seria lei formal, mas "ato complexo em que se pede a participação do Legislativo", uma "autorização para a prática de um ato que pede a colaboração do Legislativo".

Esse argumento contra o conhecimento da ação apresenta algumas premissas problemáticas: a) um conteúdo veiculado por uma lei pode não ser normativo; b) um conteúdo veiculado por lei ou por MP pode não ser sequer lei formal; c) o conteúdo orçamentário não passa de uma atribuição do Executivo com mera participação ou colaboração do Legislativo.

Um dos argumentos mais debatidos no acórdão, e certamente decisivo, foi proferido diversas vezes já na análise do mérito, acerca da legitimidade do Judiciário para analisar a legitimidade do conteúdo das expressões "guerra", "comoção interna", “calamidade pública” e "imprevisibilidade e urgência.

Seria a legitimidade para decidir tais questões do Congresso Nacional, que já haveria aprovado a Medida Provisória, e não caberia ao Poder Judiciário substituí-lo? Seria a MP um ato caracterizado pela ampla discricionariedade, cabendo apenas ao Executivo a formulação dos critérios de urgência, relevância, imprescindibilidade, impossibilidade de previsão, imprevisibilidade etc.? Não caberia ao STF o exame da conveniência e oportunidade da abertura de créditos extraordinários, mas apenas atuar em situações de claro abuso?

Um dos ministros chegou a afirmar, num claro momento de self-restraint, que não se sentia autorizado pela Constituição a fazer tais juízos, embora vislumbrasse a adequação das despesas questionadas aos critérios exigidos.

Os argumentos formulados são deontológicos porque especulam qual o âmbito de autorização constitucional para julgar certas questões. Isto é, considerando que há um dever de julgar constitucionalmente estabelecido, os argumentos procuram demonstrar a alegação de que a questão tratada estaria fora desse âmbito de atuação, deslegitimando possíveis decisões que entrassem nessa seara. 
As premissas podem ser assim aferidas: a) há um espaço de atuação que o Judiciário pode "invadir", e há um outro que não; b) o Judiciário, portanto, não tem legitimidade para decidir qualquer questão; c) onde há discricionariedade do Executivo, em regra, não deve haver controle judicial; d) só pode haver controle judicial da discricionariedade quando houver abuso claro; e) nesse caso, não seria possível vislumbrar um abuso ou o grave descumprimento dos conceitos examinados.

Esse argumento derrotado tem premissas questionáveis, e fez bem o STF em não fazê-lo prevalecer. Afinal, há coisas que a Constituição claramente disse, para mandar, proibir ou permitir; coisas de que a Constituição não disse absolutamente nada; e coisas de que não se sabe se foi dito algo, e que dependem de como são interpretados os seus enunciados. ${ }^{438}$ Nesse caso, embora os conceitos necessitem de interpretação e possa haver interpretações divergentes para delimitar o âmbito da sua autorização, a Constituição claramente os dispôs como requisito de validade para a formulação das Medidas Provisórias que tratem de créditos extraordinários. Questionar a legitimidade de atuação do Judiciário nesse caso, portanto, beira o absurdo.

O último argumento deontológico importante foi sobre a jurisprudência do STF ao não analisar leis de efeitos concretos. Acertadamente argumentou a Ministra Ellen Gracie que o caso seria diverso da ADI 2.925, que o STF reconheceu abstração na norma atacada, não mudando, portanto, esse paradigma jurisprudencial de não aceitar no controle principal normas não dotadas de abstração. Não há problema algum, desse modo, com o argumento, mas o STF resolveu mudar o entendimento nessa ADI.

\section{Argumentos Consequencialistas Jurídicos (ACJ)}

$\mathrm{O}$ argumento consequencialista mais forte, e que constitui o ratio decidendi da decisão, é o do perigo do descontrole de constitucionalidade das leis e normas orçamentárias, assim como prevaleceu na ADI 2.925.

Falou-se em insegurança, por colocar a "salvo do controle de constitucionalidade um sem-número de leis"; em "criar um cavalo de Tróia no sistema de controle de constitucionalidade"; que se estaria "criando um bill de indenidade em relação a essas normas como um todo. Por isso me parece insusceptível"; e que "se fôssemos

\footnotetext{
${ }^{438}$ GARCÍA AMADO, Juan Antonio. Derechos y pretextos: elementos de crítica del neoconstitucionalismo. In: CARBONELL, Miguel (Ed.). Teoria del neoconstitucionalismo - ensayos escogidos. Madrid: Trotta, 2008, p. 238.
} 
assumir uma posição radical, ficaríamos sem mecanismo de controle". E concluiu-se que “A lei orçamentária é a lei materialmente mais importante do ordenamento jurídico logo abaixo da Constituição. E deixar essa lei do lado de fora do controle de constitucionalidade, em processos objetivos, parece um contra-senso realmente”. A questão ainda é resumida numa última passagem:

Ora, se a Constituição submete a lei ao processo abstrato, até por ser este
o meio próprio de inovação na ordem jurídica e o instrumento adequado
de concretização da ordem constitucional, não parece admissível que o
intérprete debilite essa garantia da Constituição, isentando um número
elevado de atos aprovados sob a forma de lei do controle abstrato de
normas e, muito provavelmente, de qualquer forma de controle. É que
muitos desses atos, por não envolverem situações subjetivas, dificilmente
poderão ser submetidos a um controle de legitimidade no âmbito da
jurisdição ordinária.

O argumento, assim como visto na ADI 2.925, apresenta as seguintes premissas: a) todos os instrumentos normativos produzidos devem sofrer controle de constitucionalidade; b) o controle repressivo é essencial para proteger a segurança jurídica e a supremacia da Constituição; c) nenhum instrumento normativo deve deixar de sofrer o controle de constitucionalidade repressivo, quando for preciso; d) o controle de constitucionalidade incidental não é suficiente para proteger todos os instrumentos normativos no Brasil; e) o controle de constitucionalidade principal é necessário para proteger leis e normas orçamentárias.

Outro argumento consequencialista, agora obiter dictum, diz respeito à relevância jurídica e à política apontada por um dos ministros em relação ao tema. De acordo com esse argumento apresentado, a Corte não poderia se furtar à análise do tema posto na ação, dada a sua inegável relevância jurídica e política.

$\mathrm{O}$ argumento é interessante porque condiciona a análise de uma matéria à sua relevância jurídica e política. Tem-se a alegação, portanto, de que matérias podem ser ou não analisadas diante da análise dos efeitos que o resultado do julgamento pode produzir. $\mathrm{E}$ as seguintes premissas: a) é possível deixar de analisar uma matéria se ela não for relevante jurídica ou politicamente; b) a decisão judicial importa além da decisão do caso concreto; c) é possível utilizar a consequência em detrimento da pura deontologia na análise da admissibilidade de um recurso.

Um argumento consequencialista muito interessante, apesar de obiter dictum, foi também formulado pelo relator, num momento mais avançado da discussão, sobre a 
sede cautelar adequada para discutir a questão orçamentária. Esse argumento confronta com outro apresentado na ADI 4.904, que deixou de conhecer da matéria em cautelar, devido à suposta inadequação pela impossibilidade de aprofundar a matéria em cautelar.

A alegação é a de que a sede cautelar seria adequada em razão da característica marcante das leis e normas orçamentárias da periodicidade. Isto é, tendo em vista que as leis orçamentárias são periódicas, muitas vezes se torna impossível analisar as questões em decisões finais. Essa característica, portanto, impõe muitas vezes a sede cautelar como a decisão final sobre a matéria, e assim se deu na ADI 4.048 e em outras ADIs com o mesmo objeto.

O último argumento consequencialista relevante foi formulado pelo Ministro Celso de Mello e corroborado pelo relator, de que dez por cento do orçamento efetivamente estaria sendo praticado mediante crédito extraordinário, por medida provisória, o que mostraria o impacto da decisão e também como o caso concreto representaria uma realidade mais ampla e danosa ao sistema jurídico.

Além de consistir num argumento consequencialista, a preocupação está alinhada ao que MacCormick tem na conta de universalidade. Isso porque apresenta as seguintes premissas: a) uma decisão judicial impacta outras decisões que são tomadas no futuro; b) as pessoas tendem a seguir os mandamentos das decisões judiciais; c) há outras situações semelhantes que podem ser influenciadas, mesmo que não estejam formalmente sendo julgadas no processo; d) as decisões configuram, portanto, e ainda mais as do STF, precedentes.

\section{Argumentos Consequencialistas Extrajurídicos (ACE)}

Um único argumento encontrado pode ser classificado como consequencialista extrajurídico. E de menor importância na decisão, portanto, obiter dictum. Segundo o argumento formulado, as Medidas Provisórias seriam aceitáveis diante da inércia do Poder Legislativo em cumprir as suas funções - segundo a Ministra, um “apagão legislativo". Isso facultaria ao Executivo produzir tais instrumentos. Cita ainda o caso de 2008, quando o orçamento nacional teria excedido o prazo constitucional.

Suas premissas são: a) MPs são instrumentos do Executivo a ser utilizados diante da inércia do Legislativo; b) a inércia do Legislativo é um mal e não um sinal de desacordo com as políticas e propostas do Executivo. 
Uma premissa oculta, e que não pode ser efetivamente atribuída ao argumento, mas que certamente pode ser imaginada, seria: c) circunstâncias excepcionais, como a ausência de orçamento, poderiam levar ao abrandamento dos requisitos para a formulação de uma MP.

As premissas apresentadas demonstram a natureza consequencialista do argumento, que ultrapassa a proposta de MacCormick do tipo de orientação que deve ser seguido numa decisão.

\section{Análise da Composição de Argumentos}

A ADI 4.048 é, sem dúvida, a decisão mais importante proferida no controle de constitucionalidade de leis e normas orçamentárias no Brasil - basicamente por reconhecer a possibilidade de controlar por ADI qualquer lei ou norma orçamentária, ${ }^{439}$ independentemente do conteúdo das normas apresentadas.

Uma dúvida restou na leitura do acórdão. O relator diz que não deve haver controle de constitucionalidade de normas de efeito concreto, a não ser as veiculadas sob a forma de lei. Em sentido contrário, um argumento foi produzido afirmando que abstrato seria, na verdade, o processo do controle principal, não o ato legislativo submetido ao controle.

A decisão, portanto, não deixa absolutamente claro se os atos infralegais ou não revestidos pelo aspecto da lei formal necessitam apresentar as características da abstração ou generalidade para que se submetam ao controle principal, embora pelo conjunto dos argumentos se possa entender que os requisitos da abstração e generalidade, de acordo com a decisão, apenas deixariam de ser relevantes nos instrumentos normativos legais ou com força de lei, como no caso das Medidas Provisórias.

Prevaleceu, portanto, a noção de que não seria mais necessária a densidade normativa para que normas veiculadas por leis ou instrumentos equivalentes, como as MPs, fossem expostas ao controle principal ou abstrato de constitucionalidade.

É possível observar a grande presença de argumentos consequencialistas na decisão, até mesmo em sua ratio decidendi. Isso quer dizer que argumentos dessa natureza tiveram um papel central ou destacado nas razões apresentadas pelos Ministros para afastar a jurisprudência anterior, admitindo o controle por ADI de normas de "efeitos concretos".

\footnotetext{
${ }^{439}$ No caso do Supremo Tribunal Federal.
} 
Ao lado dessa razão consequencialista, a razão deontológica também não pode ser desprezada no acórdão. Especialmente o argumento sobre a aplicação do artigo 102, I, $a$, da Constituição, que disciplina o objeto da competência do Supremo Tribunal Federal.

A disposição desse artigo constitucional sempre foi interpretada como uma exigência do caráter normativo das leis apresentadas para o crivo do controle por ADI. E esse caráter normativo era entendido pela exigência de abstração e generalidade das normas verificadas.

É possível afirmar que o acórdão apresenta paradigma diverso da ADI 2.925, que apesar de efetuar o controle de constitucionalidade sobre norma orçamentária, utilizando muitos dos argumentos consequencialistas usados na ADI 4.048, reconheceu a possibilidade de controle de qualquer norma presente na lei, e não apenas das que apresentem caráter genérico e abstrato.

\subsubsection{ADI 4.049/DF: crédito extraordinário por Medida Provisória ${ }^{440}$}

\section{Contexto do Acórdão e Dispositivos Atacados}

O Partido da Social Democracia Brasileira - PSDB ajuizou Ação Direta de Inconstitucionalidade com pedido de medida cautelar para a declaração de inconstitucionalidade da Medida Provisória $\mathrm{n}^{\circ}$ 402, de 23.11.2007.

A petição inicial afirma que "a jurisprudência do Supremo Tribunal Federal é farta no sentido de afastar - de entender que não cabe - ação direta de inconstitucionalidade contra normas orçamentárias, porque essas são destituídas de abstração e generalidade, isto é, porque não são atos de densidade normativa. O mesmo entendimento é dispensado às medidas provisórias que abrem crédito orçamentário". Assim o fez porque, embora a ADI 4.049 tenha sido julgada depois da ADI 4.048, no momento de seu peticionamento ainda não havia sido julgada a ADI que iria desafiar a jurisprudência anterior do Supremo Tribunal Federal.

A petição inicial proposta pelo PSDB utiliza largamente a doutrina produzida pelo Ministro Gilmar Mendes, criticando a jurisprudência do STF que deixava de analisar questões orçamentárias, mas afirma que, neste caso, “com efeito, não se está, aqui, a discutir o conteúdo de um crédito extraordinário em si mesmo, mas, sim, o real

\footnotetext{
${ }^{440}$ STF. ADI de no 4.049. Rel. Min. Carlos Britto. Publicado no DJ de 5.11.2008.
} 
enquadramento de um determinado crédito na categoria de "extraordinário", a única que a Constituição de 1988 admite à medida provisória”. E utiliza um argumento consequencialista quando justifica que,

do contrário, medidas provisórias sobre créditos extraordinários seriam mais fortes do que leis ordinárias, porque escapariam ao controle de constitucionalidade, bem assim ficaria destituída de sentido a norma constitucional - que é excepcional - sobre a abertura de crédito extraordinário.

Afirma, por fim, que a não extirpação imediata da medida provisória levaria a graves prejuízos e outros efeitos danosos irreversíveis, diante da sua vigência imediata, como disposto no artigo $3^{\circ}$ do veículo atacado.

$\mathrm{Na}$ manifestação da Presidência da República sobre a ação, contesta-se a urgência da medida cautelar com o argumento de que a Medida Provisória teria sido publicada em 26 de novembro de 2007 e que o protocolo da ADI pelo partido de oposição apenas teria se dado em 12 de março de 2008, decorridos mais de três meses.

A manifestação se apoia ainda na jurisprudência "iterativa" do Supremo Tribunal Federal, afirmando que o ato normativo atacado seria de efeito concreto, e que "a efetividade da referida Medida Provisória se esgota com a aprovação do crédito extraordinário autorizado e exaure-se com sua conversão em lei pelo Congresso Nacional”.

O relator, Ministro Carlos Ayres Britto, inicia seu voto assentando o cabimento da ADI. Começa pela interpretação do dispositivo constitucional que dispõe ser objeto da ação direta de inconstitucionalidade lei ou ato normativo, afirmando que as leis não precisariam de densidade normativa para se expor ao controle de constitucionalidade, mas apenas os atos que não fossem caracterizados como lei formal.

Como no caso trata-se de medida provisória, o relator constrói o seguinte argumento:

Já no caso de medida provisória, cuida-se de espécime legislativo que inova primariamente a Ordem Jurídica, porque a própria Constituição foi que explicitou, no art. 62, que ela (medida provisória) seria editada com força de lei. É dizer: medida provisória não é lei, mas tem a força de lei, conforme doutrina Celso Antônio Bandeira de Melo. E eu complemento: a força para inovar primariamente a ordem jurídica, para aplicar por modo primaz a Constituição, tanto quanto a própria lei ordinária o faz.

Em seu voto, o Ministro Carlos Britto afirma sobre o instrumento normativo atacado: 
Não é, portanto, um ato de efeito concreto senão na aparência, porque, para ser executada, a lei orçamentária reclama a edição de muitos outros atos, estes, sim, de efeitos concretos. E enquanto esses outros atos concretos não alcançarem o seu ponto de exaustão, a lei orçamentária sobrevive à espera de novos atos de sua concreta aplicabilidade. O que já significa predisposição para um tipo gradual de incidência. Não de uma só vez. Em suma, não se está diante de medida provisória que exaure sua eficácia no ato de sua primeira aplicação. Ela somente vai consumar sua aplicabilidade, em rigor, ao final do exercício financeiro para o qual foi aberto o crédito extraordinário, quando já expedidos todos os atos de empenho, liquidação e pagamento das despesas por esse tipo de crédito fixadas.

No mérito, analisando os anexos da Medida Provisória, o Ministro relator conclui que "nenhuma das despesas a que faz referência se ajusta, minimamente que seja, aos conceitos de imprevisibilidade e urgência". E cita como exemplo despesas para "gestão e administração do programa Corredor Araguaia-Tocantins", para "modernização do DNIT" e para "implantação de perímetros de irrigação".

A Medida Provisória seria, na verdade, uma tentativa de contornar a vedação imposta pelo inciso V do art. 167 da Constituição Federal, que determina a autorização legislativa para abertura de créditos especial.

O Ministro Ricardo Lewandowski afirma que se pudesse examinar a preliminar, se pronunciaria pelo não conhecimento da ação, mas que superada essa fase, vota pelo indeferimento da medida cautelar porque não seria "dado ao Judiciário substituirse aos Poderes Executivo e Legislativo para glosar decisão relativa a critérios de relevância, urgência e imprevisibilidade, salvo em casos de evidente abuso de poder ou desvio de finalidade, que não é o caso dos autos".

O Ministro Cezar Peluso, apesar de no mérito indeferir a cautelar, é categórico ao constatar a mudança de jurisprudência da Corte para aceitar o controle principal das leis orçamentárias por via de ADI: “é que este Tribunal, alterando sua jurisprudência, já tornou claro que norma ou lei de efeito concreto é susceptível de controle abstrato na ação direta.

Trata-se de posição que está agora consolidada na Corte”. (Grifo nosso)

Argumenta o Ministro Marco Aurélio:

Não me consta que esta Corte seja guardiã, em parte, da Carta da República. Ela é guardiã na totalidade, inclusive quanto a esses predicados mencionados pelo relator: relevância, urgência e emergência, sendo que, no tocante ao crédito suplementar, tem-se até um advérbio de modo: somente é possível abertura - somente - se configurado um dos casos previstos. 
O Ministro Gilmar Mendes, comentando a afirmação do Ministro Marco Aurélio e expondo claramente uma preocupação consequencialista, assevera que esse mecanismo, somado à regra do trancamento de pauta que as Medidas Provisórias impõem, levaria a uma expropriação da agenda do Legislativo, com "grave consequência para a funcionalidade dos Poderes".

Em concordância, o Ministro Marco Aurélio observa que o cenário desperta uma ideia: "limitar o número de medidas provisórias, até mesmo para que o exercício dessa atribuição não se torne abusivo".

O Ministro Celso de Mello chama o julgamento da ADI 4.048 de precedente para conceder a medida cautelar, e explicita voto muito semelhante ao proferido naquela ADI, repetindo vários dos argumentos citados na análise anterior deste trabalho, afirmando também que a Corte

entendeu possível a utilização do processo de controle abstrato como instrumento de viabilização da defesa objetiva da ordem constitucional, mesmo tratando-se de legislação que disponha sobre previsão da receita, fixação da despesas ou autorizacão para abertura de créditos adicionais, desde que o ato estatal, como sucede na espécie de julgamento, faca instaurar litígio jurídico-constitucional suscetível de exame em tese, que possibilite a fiscalização da espécie normativa posta em confronto direto e imediato com o próprio texto da Constituição. (Grifo no original)

Ressalta ainda o Ministro Celso de Mello que não há nenhum efeito jurídico na conversão da Medida Provisória em Lei, tendo em vista o caráter inconvalidável do vício da ilegitimidade constitucional.

Por fim, o Ministro Gilmar Mendes, na condição de Presidente do Supremo Tribunal Federal, afirma que a sindicabilidade da medida provisória e de seus requisitos perante o Judiciário já seria pacífica no Tribunal. Acrescenta que essa mudança seria importante "porque ficava um espaço fora do controle judicial, e em espaço sensível, exatamente no espaço orçamentário, a lei orçamentária e, depois, os seus desdobramentos, os créditos extraordinários".

A disposição final do Acórdão é a de que "A abertura de crédito extraordinário para pagamento de despesas de simples custeio e investimentos triviais, que evidentemente não se caracterizam pela imprevisibilidade e urgência, viola o $\$ 3^{\circ}$ do art. 167 da Constituição Federal". 
Ministros vencedores: Carlos Britto, Gilmar Mendes, Celso de Mello, Ellen Gracie, Carmen Lúcia, Marco Aurélio. Ministros vencidos: Menezes Direito, Ricardo Lewandowski, Eros Grau, Cezar Peluso. Ministro ausente: Joaquim Barbosa.

\section{Argumentos Deontológicos (AD)}

O primeiro argumento desenvolvido pelo relator, e ratio decidendi, Ministro Carlos Ayres Britto, foi estritamente deontológico, interpretando o artigo 102, I, $a$, da Constituição, que regula a matéria objeto controle de constitucionalidade principal por ADI, no sentido de que as leis não necessitariam apresentar densidade normativa para se expor ao controle de constitucionalidade principal, mas só atos que não fossem caracterizados como lei formal, o que não incluiria as Medidas Provisórias.

Identificam-se as seguintes premissas: a) Medidas Provisórias são instrumentos normativos que produzem os mesmos efeitos de lei formal; b) leis podem não apresentar densidade normativa; c) a Constituição não restringiu o acesso ao controle principal de constitucionalidade dos atos constituídos por lei aos que possuam densidade normativa.

A primeira premissa (a) parece não apresentar tantos problemas. No tópico específico sobre Medidas Provisórias, embora alguns autores considerem tais instrumentos normativos projetos de lei com eficácia antecipada, é perfeitamente plausível considerar as Medidas Provisórias, dadas as suas características particulares, instrumentos em igual patamar às leis formais.

A premissa seguinte (b), no entanto, é questionável. No mínimo a nomenclatura do que se quer expressar não está adequada. Leis não podem deixar de possuir densidade normativa. No máximo, leis veiculam normas de caráter concreto e não abstrato. Certamente foi a isso que o Ministro se referiu com a expressão. Nesse sentido, as premissas $b$ e $c$ se justificam. Ou seja, é possível e adequado que o Tribunal estabeleça, segundo a redação dos textos normativos analisados, uma exigência, apenas aplicável aos atos infralegais, de que as normas sejam gerais e abstratas para que sofram o crivo do controle principal de constitucionalidade.

Outro argumento produzido pelo relator, agora obiter dictum, foi o de que cabe ADI para conhecer a matéria proposta, por se tratar de matéria que inova a ordem jurídica. A alegação, dessa forma, é a de que certos instrumentos, independentemente do conteúdo, inovam a ordem jurídica e, por isso, devem sofrer controle de constitucionalidade. 
São suas premissas: a) deve haver controle de constitucionalidade para proteger a ordem jurídica; b) todos os instrumentos que a inovam devem sofrer tal controle; c) para haver controle principal é necessário que o instrumento inove a ordem jurídica.

$\mathrm{O}$ segundo argumento soma-se ao primeiro, no sentido de delimitar o âmbito de atuação do controle principal de constitucionalidade - e todas as premissas do argumento caminham nesse sentido. A única ressalva a ser feita é a que também foi formulada no argumento anterior, em relação à densidade normativa: se todas as leis têm densidade normativa, também é de se supor que não há lei que não inove o ordenamento jurídico. $\mathrm{O}$ argumento parece, portanto, desnecessário e um falso critério para avaliar a possibilidade de controle de constitucionalidade de normas.

No mérito, diversos argumentos deontológicos foram levantados. O primeiro diz respeito ao não ajuste das despesas veiculadas pela MP aos conceitos de imprevisibilidade e urgência. É um argumento dessa natureza por verificar a adequação dos fatos expostos no processo aos conceitos da hipótese exigida pela norma.

Outro argumento que merece ser destacado, esse obiter dictum, reside no voto vencido do Ministro Lewandowski, de que não caberia ao Judiciário substituir-se aos Poderes Executivo e Legislativo na avaliação dos critérios de relevância, urgência e imprevisibilidade, salvo nos casos de abuso de poder ou desvio de finalidade. Apesar de o argumento não ser central nesta decisão, ele prevaleceu na análise do mesmo Ministro como relator em ADI julgada no futuro, a de $\mathrm{n}^{\circ} 4.904$.

\section{Argumentos Consequencialistas Jurídicos (ACJ)}

Dois argumentos consequencialistas foram encontrados nas decisões, num primeiro momento, relacionados ao abuso das Medidas Provisórias e ao papel do Tribunal em conter tais abusos, e num segundo, recorrente às ADIs 2.925 e 4.048, sobre a falta de controle das leis e normas orçamentárias.

O primeiro, apresentado pelos Ministros Gilmar Mendes e Marco Aurélio, alega que o mecanismo da Medida Provisória, utilizado dessa forma, teria como consequência esvaziar o espaço do Legislativo, em detrimento da funcionalidade entre os Poderes.

Alega-se, portanto, que limitar o uso de MPs é necessário para proteger, como consequência, não um caso isolado, mas um contexto que pode levar a um desequilíbrio entre os Poderes. 
O outro argumento foi recorrente especialmente nas ADIs 2.925 e 4.048, do status jurídico de ausência de controle de leis e normas orçamentárias dela decorrentes, como os créditos extraordinários, no caso de não conhecimento da ação.

\section{Análise da Composição de Argumentos}

Por fim, o argumento proposto pelo Ministro Peluso merece destaque por um motivo especial. Ele firma o entendimento de que o Supremo Tribunal Federal já possui jurisprudência $^{441}$ no sentido de que norma ou lei de efeito concreto são susceptíveis ao controle de constitucionalidade abstrato na ação direta, o que se consolida com a presente decisão.

O exposto pelo Ministro Peluso é relevante especialmente na discussão dos pontos finais, que buscarão estabelecer qual o precedente hoje no controle de constitucionalidade de leis e normas orçamentárias. Do mesmo modo se pronuncia o Ministro Celso de Mello.

$\mathrm{Na}$ ementa, vale ressaltar, é explícito que "A lei não precisa de densidade normativa para se expor ao controle abstrato de constitucionalidade, devido a que se trata de ato de aplicação primária da Constituição". Exige-se a densidade normativa apenas de atos infralegais.

\subsubsection{ADI 4.904/DF: crédito extraordinário por Medida Provisória ${ }^{442}$}

\section{Contexto do Acórdão e Dispositivos Atacados}

O Partido da Social Democracia Brasileira - PSDB e o Democratas - DEM propuseram a Ação Direta de Inconstitucionalidade com pedido de Medida Cautelar, tendo como objetivo a declaração de inconstitucionalidade da Medida Provisória de no 598 , de 27.12.2012, que abriu crédito extraordinário em favor de diversos órgãos e empresas estatais.

O valor total aberto por meio de crédito extraordinário em medida provisória foi de quase 47 bilhões de reais.

A petição inicial dá como superada a orientação tradicional do Supremo

\footnotetext{
${ }^{441}$ Muito embora apenas se tenha a ADI 4.048 nesse sentido, e anterior à decisão em análise.
}

${ }^{442}$ STF. ADI de no 4.904. Rel. Min. Marco Aurélio. Publicado no DJ de 31.1.2013. 
Tribunal Federal que afastava o cabimento de ADI em matéria orçamentária, "por entender ausentes os caracteres de generalidade e abstração, até então concebidos como indispensáveis para tal modalidade de controle judicial".

Relata também o percurso jurisprudencial recente, passando pela ADI 2.925 e chegando finalmente à ADI 4.048 como novo paradigma e precedente constitucional da matéria.

A petição ainda reforça o argumento consequencialista de que,

Com efeito, as leis orçamentárias estão entre os tipos de normas que, afastadas da fiscalização abstrata, dificilmente poderão ter sua validade fiscalizada no âmbito da jurisdição ordinária, já que não envolvem diretamente situações subjetivas. Ficariam, por conseguinte, livres de qualquer forma de apreciação judicial, ainda que violadoras das normas da Constituição.

Colocando claramente o argumento deontológico em segundo plano, afirmam os partidos: “Além disso, não há no texto constitucional razão que justifique negar-se a via do controle concentrado às normas orçamentárias, especialmente quando se considera que essas são certamente as leis mais importantes abaixo da Constituição Federal".

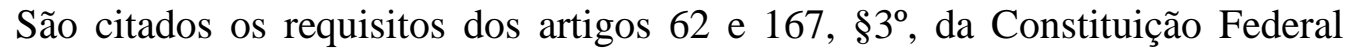
como não adimplidos pela Medida Provisória atacada, de forma que nenhum dos gastos poderia, "legitimamente, ser enquadrado como despesa imprevisível e extraordinária. Os gastos autorizados dizem respeito a despesas ordinárias para fazer frente a situações previstas ou, ao menos, previsíveis".

A peça inicial pretende ainda afastar o self-restraint do Tribunal, quando afirma que "não se pretende discutir o conteúdo do juízo político relativo à alocação de recursos públicos", mas

a ocorrência ou não dos pressupostos autorizadores da utilização de créditos extraordinários ou, em outras palavras, o real enquadramento de determinado crédito na categoria dos 'créditos extraordinários', única situação em que a Constituição Federal de 88 admite o emprego de medida provisória em matéria orçamentária.

Os partidos autores da ação argumentam em favor da previsibilidade das despesas veiculadas que, "na realidade, a maior parte delas já havia sido prevista e encaminhada ao Congresso Nacional na forma de diferentes projetos de lei, que, entretanto, não chegaram a ser aprovados antes da edição da medida provisória ora 
impugnada". Outro argumento a favor da interpretação da previsibilidade das despesas é a interpretação do trecho produzido na exposição de motivos no 00341/2012. Este diz que "o crédito permitirá a continuidade da execucão de investimentos prioritários no exercício

de 2013, com destaque para grandes obras de infraestrutura implementadas pelo Governo Federal, de forma a evitar atrasos em seus cronogramas de execução (...)". Ou seja, a redação que exporia os motivos denuncia a previsibilidade das despesas ao requerer a continuidade da execução de investimentos de forma a evitar atrasos. Dessa forma, se os investimentos já eram feitos, mais racional que o processo adequado seja o que permite a criação de créditos suplementares.

$\mathrm{Na}$ mesma linha, analisam outro item da exposição de motivos, em que as despesas relativas ao Ministério do Planejamento, Orçamento e Gestão seriam destinadas “à manutenção dos sistemas estruturantes e corporativos, bem como (...) as recomposições do capital ordinário da Corporação Andina de Fomento, aprovada em 18 de agosto de 2009 , e do Banco Interamericano de Desenvolvimento, aprovada em 22 de marco de 2010".

Os autores resumem ainda as três razões ou argumentos apresentados na exposição de motivos para satisfazer os requisitos constitucionais de relevância e urgência do crédito extraordinário em exame, que seriam:

(1) a não aprovação de certos projetos de lei de crédito adicional ali enumerados, (2) a não aprovação do projeto de Lei Orçamentária Anual para o exercício de 2013 e (3) a necessidade de 'manter o ritmo de execução dentro do previsto' para certas ações em desenvolvimento no exercício de 2012.

A petição inicial destaca ainda argumento importante para entender a ofensa ao princípio da separação dos poderes realizada no caso em análise: "O silêncio do Legislativo, na hipótese, é eloquente. O Congresso Nacional optou deliberadamente por não deliberar sobre as referidas proposições. Trata-se de juízo político a cargo do Legislativo, que não pode ser elidido por interferência dos demais Poderes”. Ou seja, as justificativas que levam o Executivo a propor medidas provisórias seriam justamente a não concordância ou a falta de análise do Legislativo sobre questões orçamentárias, de forma a burlar o devido processo legislativo orçamentário.

Os partidos autores trabalham nesse sentido a ideia de que a não aprovação do projeto de Lei Orçamentária Anual, que se costuma chamar de "anomia orçamentária", não autorizaria a abertura de crédito extraordinário por medida provisória. Cita para esse fim o 
artigo 50 da Lei de Diretrizes Orçamentárias daquele ano, que prevê expressamente quais despesas e programas poderão ser executados e as condições de execução em caso de não aprovação do orçamento.

É citada ainda na peça inicial a Nota Técnica n ${ }^{\circ}$ 2/2013 da Consultoria de Orçamento e Fiscalização Financeira da Câmara dos Deputados. Esta explicita que "os limites constitucionais relacionados à relevância, urgência e imprevisibilidade deixaram de ser observados pela MP 598/2012”.

Por fim, em seu pedido, o perigo da demora é justificado pelos possíveis danos irreversíveis ao erário e à ordem jurídica, devido à inobservância do processo legislativo orçamentário, pois uma vez executados todos os recursos autorizados inconstitucionalmente, restaria "sensivelmente reduzida a eficácia da declaração de inconstitucionalidade a ser proferida por esta Corte".

Ao analisar a liminar na ADI 4.904, o Ministro Ricardo Lewandowski entendeu que, embora o Supremo Tribunal Federal tenha decidido, em mais de uma ocasião, que haveria

a necessidade de imposição de limites à atividade legislativa excepcional do Poder Executivo, especialmente na edição de medidas provisórias para abertura de crédito extraordinário (cf. ADI 4.048-MC/DF, Rel. Min. GILMAR MENDES), em nenhum momento vedou, de forma peremptória, a utilização dessa espécie de ato normativo em situações de relevância e urgência.

O principal argumento utilizado pelo Ministro Ricardo Lewandowski é o de que:

Ademais, como regra, não cabe ao Judiciário, em um exame perfunctório, típico da jurisdição cautelar, em se tratando de medidas provisórias que versem sobre matéria financeira, afastar, de plano, a presença dos requisitos de relevância e urgência invocados pelo Executivo para baixar tais atos, sem empreender uma análise mais aprofundada das despesas que, a juízo da autoridade competente, devem ser atendidas em caráter emergencial.

Por fim, o Ministro indeferiu a liminar, com base no instituto do

periculum in mora inverso, ou seja, a suspensão do ato poderia causar danos de difícil reparação não apenas ao Estado brasileiro como também para a própria sociedade, que se veria irremediavelmente prejudicada pela paralisação de serviços públicos essenciais, conforme explicitado pelo Executivo.

Decisão proferida monocraticamente pelo Ministro Ricardo Lewandowski. 


\section{Argumentos Deontológicos (AD)}

Os dois primeiros argumentos esboçados pelo Ministro na decisão liminar podem ser classificados como deontológicos. O primeiro é sobre a aplicação da jurisprudência da matéria sobre o caso.

São premissas do argumento: a) devem ser aplicadas decisões anteriores a casos futuros semelhantes; b) há um precedente, que deve ser seguido, estabelecido na ADI 4.048 ; c) o precedente não proibiu o uso de Medida Provisória para tratar de crédito extraordinário; d) nesse caso específico em análise, estariam presentes os requisitos da relevância e urgência; e) também estariam presentes os requisitos dos créditos extraordinários constitucionalmente definidos.

Não há problema algum nos três primeiros precedentes $(a, b$ e $c)$. Isto é, decisões anteriores do mesmo tribunal sobre a mesma matéria, por uma série de razões já expostas, devem ser seguidas na maior medida possível. E a ADI 4.048, que será tratada no fim deste capítulo, é efetivamente o principal precedente da matéria. Também não há, como suposto pelo Ministro, uma norma proibitiva absoluta para o uso de Medida Provisória em matéria orçamentária, especificamente no que diz respeito aos créditos extraordinários. A Constituição é bem clara sobre o assunto.

Maiores questionamentos, no entanto, podem ser feitos às premissas (c) e (d). Mas elas envolvem o exame das normas questionadas na ADI, que não foram citadas nem analisadas no acórdão. O assunto será abordado quando da análise da composição dos argumentos.

O segundo é sobre a legitimidade do Judiciário para decidir sobre tais questões. Afirmou o Ministro que:

\footnotetext{
Ademais, como regra, não cabe ao Judiciário, em um exame perfunctório, típico da jurisdição cautelar, em se tratando de medidas provisórias que versem sobre matéria financeira, afastar, de plano, a presença dos requisitos de relevância e urgência invocados pelo Executivo para baixar tais atos, sem empreender uma análise mais aprofundada das despesas que, a juízo da autoridade competente, devem ser atendidas em caráter emergencial.
}

A alegação é a de que não caberia a análise, pelo Poder Judiciário, da constitucionalidade de Medidas Provisórias sem um estudo mais aprofundado.

São premissas dessa asserção: a) há questões sobre as quais o Judiciário não tem legitimidade para decidir; b) a análise da relevância e urgência de uma medida 
provisória é uma dessas questões; c) na jurisdição cautelar a análise é superficial; d) não é possível decidir a questão em sede de cautelar.

Quanto à primeira premissa (a), essa discussão é bastante relevante ao tema do ativismo judicial. Efetivamente há limites para a atuação do Judiciário, e nunca será perfeitamente claro em certas situações se o Judiciário deve atuar ou se autorrestringir.

A questão é trazida ao específico na premissa (b), onde os conceitos indeterminados "relevância e urgência" são postos pelo ministro fora do âmbito de atuação do Tribunal. O tema será abordado em seguida, na análise da composição dos argumentos.

\section{Argumentos Consequencialistas Jurídicos (ACJ)}

O último argumento levantado pelo Ministro foi com relação ao perigo da demora. Uma norma posta no ordenamento, mas que claramente impõe uma racionalidade consequencialista na concessão de medidas cautelares.

A alegação feita pelo Ministro é a de que, caso a medida cautelar fosse concedida, suspendendo a MP, causar-se-iam "danos de difícil reparação não apenas ao Estado brasileiro, como também para a própria sociedade, que se veria irremediavelmente prejudicada pela paralisação de serviços públicos essenciais”.

As premissas do argumento não são inteiramente consequencialistas, mas há uma preponderância da racionalidade consequencialista, pois: a) há uma norma que exige o perigo da demora para a concessão de medidas cautelares; b) a suspensão de uma norma constitucional depende dos possíveis efeitos que serão causados pela manutenção da produção de efeitos; c) o juiz pode avaliar os efeitos que suas decisões causam no campo social, jurídico e econômico; d) nesse caso, diante da soma das boas e más consequências de conceder ou não a liminar, o magistrado chegou à conclusão que conceder a liminar traria mais prejuízos que não a conceder.

$\mathrm{O}$ argumento em si não tem premissas problemáticas. O que se pode discordar é quanto à avaliação consequencialista realizada pelo Ministro. Isto é, discordar que as piores consequências viriam da concessão da cautelar, e sim da sua não concessão. Tentarse-á demonstrar exatamente essa hipótese a seguir.

\section{Análise da Composição de Argumentos}

Algumas críticas devem ser feitas além das premissas adotadas pelo Ministro 
na decisão, como também ao resultado do julgamento e suas consequências para o estabelecimento de um precedente e da proteção da segurança jurídica no caso.

É possível observar de início que muitos dos argumentos empregados nas iniciais não foram observados na decisão, que só traz três argumentos fundamentais expostos nos tópicos anteriores. Isso está de acordo com a posição do Ministro de que em sede de medida cautelar não seria possível analisar temas tão profundos. Muito embora isso contrarie a jurisprudência e o principal precedente da matéria, que é justamente um julgamento em sede de cautelar na ADI 4.048.

Não parece correto excluir da análise judicial o controle da aplicação de conceitos indeterminados como "relevância e urgência". Tais conceitos, apesar de indeterminados, não possibilitam nenhuma interpretação. Algumas das despesas autorizadas pela Medida Provisória parecem muito distantes de submeter-se com sucesso aos conceitos de relevância e urgência.

Fora demonstrado na petição inicial que a exposição de motivos trata da “continuidade da execução de investimentos prioritários no exercício de 2013”. Além disso, alguns trechos ressaltam esse desvio:

No Ministério da Previdência Social, o presente crédito possibilitará a continuidade das atividades de defesa judicial do Instituto Nacional do Seguro Social (...)

No Ministério do Planejamento, Orçamento e Gestão, permitirá o atendimento de despesas relativas à manutenção dos sistemas estruturantes corporativos (...)

No âmbito do Ministério do Turismo, possibilitarão o apoio em infraestrutura turística no Município de São Paulo, com o objetivo de permitir a construção de um novo Centro de Exposições para a realização de eventos de grande porte na região.

É possível perceber com facilidade não só o descumprimento dos requisitos da Medida Provisória, como dos estabelecidos para os Créditos Extraordinários, o que apenas é possível em caso de "despesas imprevisíveis e urgentes, como as decorrentes de guerra, comoção interna ou calamidade pública".

Resta demonstrado que não houve uma análise profunda da Medida Provisória, visto que as inconstitucionalidades saltam aos olhos. Não configuram, portanto, uma zona cinzenta onde a aplicação das normas constitucionais poderia ou não ter sido descumprida.

É verdade que a análise, uma a uma, das despesas autorizadas poderia ser classificada como de maior complexidade, mas essa discussão já foi desenvolvida nas ADI 4.048 e 4.049, e não foi levantado argumento que demonstrasse as diferenças no caso que 
inviabilizassem o controle.

A grande questão que essa decisão levanta, e a que se buscará responder nos últimos tópicos deste capítulo e da tese, é se essa decisão abala o precedente estabelecido pela ADI 4.048, ou se ela foi um desvio que não representa hoje a posição do Supremo Tribunal Federal sobre a matéria.

\subsubsection{ADCs e ADOs}

No site do Supremo Tribunal Federal foi feita uma pesquisa no campo exclusivo das Ações Declaratórias de Constitucionalidade - ADC e das Ações Diretas de Inconstitucionalidade por Omissão - ADO, com os termos “orçamentárias ou orçamento". Foi encontrada apenas uma ADC proposta com a expressão, e quatro ADOs já propostas em todo o histórico constitucional desde a Carta de 1988.

\begin{tabular}{|c|c|c|c|c|}
\hline $\begin{array}{c}\text { NÚMERO DA } \\
\text { AÇÃO }\end{array}$ & ORIGEM & RELATOR & TESE & RESULTADO \\
\hline ADC 1 & DF & MIN. MOREIRA ALVES & NÃO & PROCEDENTE \\
\hline ADO 7 & AM & MIN. CARMEN LÚCIA & NÃO & PREJUDICADA \\
\hline ADO 8 & SC & $\begin{array}{c}\text { MIN. RICARDO } \\
\text { LEWANDOWSKI }\end{array}$ & SIM & PREJUDICADA \\
\hline ADO 18 & DF & $\begin{array}{c}\text { MIN. ROBERTO } \\
\text { BARROSO }\end{array}$ & SIM & PENDENTE \\
\hline ADO 19 & DF & MIN. JOAQUIM BARBOSA & SIM & PENDENTE \\
\hline
\end{tabular}

No entanto, ao analisar as decisões, apenas três delas tratam efetivamente sobre o tema objeto desta tese, isto é, o controle de constitucionalidade de leis e normas orçamentárias. Todas, Ações Diretas de Inconstitucionalidade por Omissão.

Não foi encontrada, portanto, nenhuma Ação Declaratória de Constitucionalidade proposta perante o Supremo Tribunal Federal que tivesse como objeto lei ou norma orçamentária. E é bastante compreensível. As ADCs são instrumentos típicos da preservação da segurança jurídica, com as quais se busca prevenir discussões futuras sobre a aplicação de algum ato normativo infraconstitucional. Como as leis orçamentárias são todas periódicas, seria pouco proveitoso pedir a declaração de sua constitucionalidade.

Além disso, desses três processos em sede de ADO, dois restam pendentes de julgamento. Há, portanto, apenas uma decisão, que é a da ADO de n ${ }^{\circ}$ 8. Nesta ação, é questionada uma suposta omissão no cumprimento pelas leis orçamentárias do Estado de 
Santa Catarina do disposto no artigo 37, X, da Constituição Federal. ${ }^{443}$

O argumento central da ação é que, diante da obrigação constitucional e do direito dos servidores de terem as suas remunerações revisadas anualmente, haveria uma omissão quando as leis orçamentárias não trouxessem a previsão dos reajustes.

No entanto, houve a cessação da inércia diante de projeto apresentado, aprovado e convertido em lei, tratando da matéria. Julgou-se, portanto, prejudicada a matéria por superveniência de perda do objeto, numa decisão monocrática do Ministro Ricardo Lewandowski.

Não foram produzidos vários argumentos, nem há uma formação de precedente no caso. Pode-se dizer, portanto, que não há nenhum julgamento relevante sobre a matéria objeto desta tese em sede de ADO e ADC no controle de constitucionalidade brasileiro.

\subsubsection{ADPFs}

No site do Supremo Tribunal Federal foi feita uma pesquisa no campo exclusivo das Arguições de Descumprimento de Preceito Fundamental - ADPF com o mesmo termo do item anterior, "orçamentárias ou orçamento". Foram encontradas 25 (vinte e cinco) arguições já propostas em todo o histórico constitucional desde a Carta de 1988 .

\footnotetext{
443 "X - a remuneração dos servidores públicos e o subsídio de que trata o $\S 4^{\circ}$ do art. 39 somente poderão ser fixados ou alterados por lei específica, observada a iniciativa privativa em cada caso, assegurada revisão geral anual, sempre na mesma data e sem distinção de índices”. BRASIL. Constituição da República Federativa do Brasil de 1988.
} 


\begin{tabular}{|c|c|c|c|c|}
\hline $\begin{array}{l}\text { NÚMERO } \\
\text { DA ADPF }\end{array}$ & ORIGEM & RELATOR & TESE & RESULTADO \\
\hline ADPF 282 & RO & MIN. GILMAR MENDES & NÃO & PENDENTE \\
\hline ADPF 279 & SP & MIN. CÁRMEN LÚCIA & NÃO & PENDENTE \\
\hline ADPF 275 & $\mathrm{~PB}$ & MIN. TEORI ZAVASCKI & NÃO & PENDENTE \\
\hline ADPF 274 & $\mathrm{PE}$ & MIN. MARCO AURÉLIO & NÃO & NÃO CONHECIDA \\
\hline ADPF 242 & $\mathrm{DF}$ & MIN. DIAS TOFFOLI & NÃO & PENDENTE \\
\hline ADPF 240 & DF & $\begin{array}{l}\text { MIN. JOAQUIM } \\
\text { BARBOSA }\end{array}$ & SIM & PREJUDICADA \\
\hline ADPF 235 & TO & MIN. LUIZ FUX & NÃO & PENDENTE \\
\hline ADPF 234 & DF & MIN. MARCO AURÉLIO & NÃO & SOBRESTADO \\
\hline ADPF 207 & $\mathrm{BA}$ & MIN. ELLEN GRACIE & NÃO & PREJUDICADA \\
\hline ADPF 173 & SP & MIN. TEORI ZAVASCKI & NÃO & PENDENTE \\
\hline ADPF 126 & $\mathrm{DF}$ & MIN. CELSO DE MELLO & NÃO & NÃO CONHECIDA \\
\hline ADPF 109 & SP & $\begin{array}{l}\text { MIN. RICARDO } \\
\text { LEWANDOSKI }\end{array}$ & NÃO & PENDENTE \\
\hline ADPF 102 & SP & $\begin{array}{l}\text { MIN. JOAQUIM } \\
\text { BARBOSA }\end{array}$ & NÃO & NÃO CONHECIDA \\
\hline ADPF 83 & $\mathrm{ES}$ & MIN. AYRES BRITTO & NÃO & NÃO CONHECIDA \\
\hline ADPF 74 & DF & MIN. CELSO DE MELLO & NÃO & PREJUDICADA \\
\hline ADPF 73 & DF & MIN. EROS GRAU & SIM & IMPROCEDENTE \\
\hline ADPF 70 & $\mathrm{DF}$ & MIN. MARCO AURÉLIO & NÃO & PENDENTE \\
\hline ADPF 64 & $\mathrm{AP}$ & MIN. CARLOS VELLOSO & SIM & IMPROCEDENTE \\
\hline ADPF 63 & AP & $\begin{array}{l}\text { MIN. MENEZES } \\
\text { DIREITO }\end{array}$ & SIM & IMPROCEDENTE \\
\hline ADPF 49 & PI & $\begin{array}{l}\text { MIN. MENEZES } \\
\text { DIREITO }\end{array}$ & SIM & PREJUDICADA \\
\hline ADPF 46 & $\mathrm{DF}$ & MIN. MARCO AURÉLIO & NÃO & IMPROCEDENTE \\
\hline ADPF 45 & $\mathrm{DF}$ & MIN. CELSO DE MELLO & SIM & PREJUDICADA \\
\hline ADPF 37 & $\mathrm{RS}$ & $\begin{array}{l}\text { MIN. MENEZES } \\
\text { DIREITO }\end{array}$ & SIM & PREJUDICADA \\
\hline ADPF 9 & $\mathrm{RS}$ & $\begin{array}{l}\text { MIN. MENEZES } \\
\text { DIREITO }\end{array}$ & SIM & NÃO CONHECIDA \\
\hline ADPF 7 & $\mathrm{RS}$ & $\begin{array}{c}\text { MIN. ROBERTO } \\
\text { BARROSO }\end{array}$ & SIM & PENDENTE \\
\hline
\end{tabular}

A bem da verdade, como a regulação da ADPF apenas foi feita mais de dez anos após a promulgação da Constituição, a primeira ação dessa natureza apenas fora proposta no fim do ano de 1999.

Dessas 25 encontradas, apenas nove efetivamente tratam da matéria objeto do estudo deste trabalho, ${ }^{444}$ isto é, a produção de leis e normas orçamentárias. Das nove que

${ }^{444}$ ADPF 240, 73, 64, 63, 49, 45, 37 e 7. 
tratam da matéria pertinente, oito já foram julgadas, e apenas uma, a mais antiga de todas, a ADPF 7, resta pendente.

Nenhuma das oito ADPFs já analisadas foi julgada procedente. Todas foram julgadas improcedentes ou prejudicadas quanto ao mérito, especialmente quando analisadas Leis de Diretrizes Orçamentárias - LDO, pelo advento posterior de Lei Orçamentária Anual, fazendo com que elas, em tese, perdessem a sua eficácia.

Esses oito acórdãos já proferidos, alguns em decisões monocráticas, negando seguimento ao recurso, serão, a partir de agora, analisados em busca da sua fundamentação. Pela brevidade das decisões e pelo pequeno número, será feita uma análise conjunta de todas elas ao final.

A primeira decisão proferida no controle de constitucionalidade de norma orçamentária em sede de ADPF ocorreu na ação número 9, onde uma norma reajustava os vencimentos dos servidores do estado do Rio Grande do Sul sem observar as leis orçamentárias.

Foram alegadas ofensas às normas dos artigos $2^{\circ}, 3^{\circ}, 37$, XII, 166, $\S 3^{\circ}$, e 169 da Constituição Federal, além do "desequilíbrio financeiro que os aumentos causariam às finanças do Estado e para a disparidade de vencimentos entre os servidores do Poder Executivo em relação aos dos Poderes Judiciário e Legislativo." ${ }^{445}$

O primeiro argumento apresentado na decisão é o descumprimento do chamado "princípio da subsidiariedade", que mais parece uma regra de competência, estabelecido no artigo $4^{\circ}, \S 1^{\circ}$, da Lei 9.882/99, que regulamentou a ADPF. Este exige que, quando houver outro meio disponível, não seja conhecida a matéria por essa via processual, pois, "No presente caso, seria cabível, pelo menos em tese, a propositura de ação direta de inconstitucionalidade, uma vez que tem por objeto leis ordinárias estaduais editadas após a promulgação da Constituição de 1988". 446

Além disso, no caso a inconstitucionalidade seria apenas reflexa, isto é, sem ofensa direta à Constituição, mas à disposição das leis orçamentárias, portanto, uma ofensa indireta à Carta.

Por fim, a decisão aponta a perda da eficácia da decisão, uma vez que teria sido modificada por outros posteriormente, além da "completa inutilidade de eventual declaração de inconstitucionalidade, já que não subsistem efeitos jurídicos a ser

\footnotetext{
${ }^{445}$ STF. ADPF de $n^{\circ} 9$. Rel. Min. Menezes Direito.

${ }^{446}$ Idem.
} 
regulados, frustrando-se, assim, a finalidade do processo de controle concentrado de constitucionalidade". 447

A ADPF de $n^{\circ} 37$ foi a segunda a tratar do tema. Nesse caso, fora questionado um dispositivo específico da Lei de Diretrizes Orçamentárias, também do estado do Rio Grande do Sul.

O primeiro argumento levantado na decisão é o do exaurimento da eficácia da norma disposta na LDO, uma vez que a LDO fora feita no ano de 2001 para orientar a elaboração do orçamento do ano de 2002; assim, “com o término do exercício financeiro de 2002, toda a Lei estadual $n^{\circ} 11.658 / 2001$ teve sua eficácia exaurida" ${ }^{448}$ O segundo e último argumento, também presente na decisão anteriormente analisada, afirma "revelar-se inútil eventual declaração de inconstitucionalidade", e com base nisso considera extinto o processo sem julgamento de mérito. ${ }^{449}$

A ADPF de $n^{\circ} 45$ questiona a constitucionalidade de um veto presidencial na Lei de Diretrizes Orçamentárias para o orçamento do ano de 2004. O veto incidiu sobre a seguinte disposição:

$\S 2^{\circ}$ Para efeito do inciso II do caput deste artigo, consideram-se ações e serviços públicos de saúde a totalidade das dotações do Ministério da Saúde, deduzidos os encargos previdenciários da União, os serviços da dívida e a parcela das despesas do Ministério financiada com recursos do Fundo de Combate à Erradicação da Pobreza. ${ }^{450}$

$\mathrm{O}$ veto contrariaria o preceito fundamental do direito à saúde, pois deixaria de garantir recursos financeiros mínimos para a área. Após prolixa fundamentação sobre a necessidade de efetivação dos direitos sociais pelo Estado, em decisão monocrática o relator julga "prejudicada a presente argüição de descumprimento de preceito fundamental, em virtude da perda superveniente de seu objeto". ${ }^{451}$

A ADPF de $n^{\circ} 49$ teve por objeto ato do Poder Legislativo do Piauí que alterou a proposta de lei orçamentária para o ano de 2004, anulando despesas de serviços da dívida pública.

Ocorre que no julgamento, no ano de 2008, o Ministro relator entendeu prejudicada a análise, pois a norma "teve sua eficácia exaurida em face de sua natureza

\footnotetext{
${ }^{447}$ STF. ADPF de no 9. Rel. Min. Menezes Direito.

${ }^{448}$ STF. ADPF de no 37. Rel. Min. Menezes Direito.

${ }^{449}$ Idem.

${ }^{450}$ STF. ADPF de no 45. Rel. Min. Celso de Mello.

${ }^{451}$ STF. ADPF de no 45. Rel. Min. Celso de Mello.
} 
transitória". Citou a jurisprudência referente à alegação e prolatou ao fim que "Ante o exposto, na linha dos precedentes acima e nos termos do art. 21, inciso IX, do RISTF, julgo prejudicada a argüição de descumprimento de preceito fundamental por falta de objeto". 452

$\mathrm{Na}$ ADPF de $\mathrm{n}^{\circ} 63$ questionou a validade de norma contida em lei que alterou disposições da lei orçamentária anual do Amapá para o ano de 2005. Alegou-se no pedido que "as alterações feitas pela lei impugnada prejudicam as prioridades estipuladas pelo Poder Executivo e prejudicam a governabilidade". 453

A decisão proferida pelo Ministro Sepúlveda Pertence em fevereiro de 2005 indefere a petição inicial, sob o argumento de que a jurisprudência do Supremo Tribunal Federal (e cita a ADI 2.108) aceitaria o controle principal de leis e normas orçamentárias, reconhecendo em alguns casos seu caráter geral. Não satisfaz, portanto, o princípio da subsidiariedade relativo às APDFs. Além do que, o pedido seria juridicamente impossível, uma vez que exigiria do Judiciário uma ação tipicamente política.

Assim como na ADPF de $n^{\circ}$ 63, a de $n^{\circ} 64$ também questionou a validade de norma contida em lei que alterou lei orçamentária no Amapá para o ano de 2005, sendo apenas uma lei orçamentária diferente, a LDO. As normas questionadas acresceram os percentuais de repasses dos demais Poderes, à exceção do Executivo, em suposto descompasse ante o PPA daquele estado. O mesmo raciocínio da decisão anterior é desenvolvido, no sentido de que:

O mesmo se passa nos presentes autos, uma vez que requer o argüente a concessão de medida liminar a fim de que seja suspensa a eficácia do dispositivo legal hostilizado, mantendo-se o veto do Poder Executivo e assegurando a aplicação da Lei de Diretrizes Orçamentárias na forma como originalmente encaminhada ao Poder Legislativo. A impossibilidade jurídica do pedido é manifesta, pois, como já se disse, o Supremo Tribunal Federal não pode exercer função legislativa. ${ }^{454}$

Afirma ainda o relator, Ministro Velloso, que, além de a ADPF ser subsidiária, nesse caso, havendo outros meios processuais adequados para a defesa da Constituição, as

\footnotetext{
${ }^{452}$ STF. ADPF de no 49. Rel. Rel. Min. Menezes Direito.

${ }^{453}$ Aqui um breve comentário: a lei orçamentária não é a expressão da vontade do rei, mas justamente o plano de governo aprovado pelo Legislativo como representante do povo. STF. ADPF de $n^{\circ}$ 63. Rel. Rel. Min. Menezes Direito.

${ }^{454}$ STF. ADPF de no 64. Rel. Rel. Min. Carlos Velloso.
} 
normas da LDO já haviam se exaurido quando da promulgação da LOA, perdendo a ação, portanto, o objeto. ${ }^{455}$

A ADPF de $n^{\circ} 73$ foi ajuizada para controlar a constitucionalidade do veto parcial do Presidente da República à LDO para o ano de 2005. É citada a ADPF 63, para reafirmar o precedente de que o STF já teria reconhecido alguma possibilidade de generalidade e abstração nas leis orçamentárias, e que, por isso, seria cabível ao caso o questionamento por outras vias, inviabilizando a subsidiariedade.

Por fim, a ADPF de $\mathrm{n}^{\circ} 240$ foi a última a questionar normas orçamentárias no sistema de controle de constitucionalidade brasileiro. Tem como objetivo "incluir no projeto de lei orçamentária de 2012 a proposta orçamentária integral do Poder Judiciário e do Ministério Público da União para o referido ano". 456

Segundo o Ministro Barroso, identificada a aprovação da LOA para o ano de 2012, a LDO que fixou suas diretrizes deixaria de produzir efeitos, levando à perda da eficácia da ação. ${ }^{457}$

Essas decisões, apesar de pouco fundamentadas, muito em razão do improvimento ou não conhecimento de todas elas, estabelecem alguns pontos gerais para avaliar os argumentos em relação à classificação consequencialista/deontológica, bem como sobre o perfil do controle de constitucionalidade de leis e normas orçamentárias no controle principal nas Arguições de Descumprimento de Preceitos Fundamentais.

Um dos argumentos mais recorrentes das decisões é o da perda de eficácia da norma investigada, que levaria necessariamente à impossibilidade de analisá-la. O argumento é de difícil classificação no binômio deontológico/consequencialista, tendo em vista que vem acompanhado da recorrente expressão "inutilidade da declaração de inconstitucionalidade". Isto é, o conceito de utilidade é um conceito eminentemente utilitarista e abarca uma das preocupações consequencialistas: avaliar as consequências em termos de utilidade para o direito.

Quanto ao tema, a jurisprudência do Supremo Tribunal Federal é vacilante em relação ao momento em que a norma deixa de produzir a eficácia no caso das Leis de Diretrizes Orçamentárias. Na ADPF 37, por exemplo, a LDO perderia a eficácia no mesmo prazo no qual a LOA orientada por ela também deixaria de viger: no fim do ano seguinte ao da sua produção. Nas demais, o que se repete da ADPF mais recente sobre o tema, a de

\footnotetext{
${ }^{455}$ Idem.

${ }^{456}$ STF. ADPF de n ${ }^{\text {o } 240 . ~ R e l . ~ R e l . ~ M i n . ~ R o b e r t o ~ B a r r o s o . ~}$

${ }^{457}$ Idem.
} 
n 240 , a perda da eficácia se dá com a produção da LOA orientada pela LDO, ou seja, no fim do ano anterior ao da decisão na ADPF 37.

A LDO, como dito no primeiro capítulo desta segunda parte, tem um período de vigência muito particular, de um ano e meio, e não de apenas seis meses. Isso porque não só ela orienta a produção da LOA, como orienta as eventuais modificações que porventura sejam produzidas ao longo do ano da sua execução. Por isso, é inexata a jurisprudência atual nas ADPFs que desconsidera a perda da eficácia no momento da produção da LOA.

$\mathrm{O}$ argumento sobre a impossibilidade jurídica do pedido em decorrência da natureza política da decisão surge em ao menos uma decisão nessa jurisprudência; se não é um argumento consequencialista por essência, também não é um argumento classicamente deontológico, visto que ressalta o debate citado no primeiro capítulo desta tese sobre o ativismo judicial e sobre a legitimidade de o Judiciário decidir acerca de questões orçamentárias.

$\mathrm{O}$ argumento sobre o princípio da subsidiariedade das Arguições de Descumprimento de Preceito Fundamental é deontológico, pois se refere à aplicação de um dispositivo da Lei 9.882/99, o $\S 1^{\circ}$ do artigo $4^{\circ}$, que dispõe: "Não será admitida argüição de descumprimento de preceito fundamental quando houver qualquer outro meio eficaz de sanar a lesividade”. Não há razões para classificar o argumento como consequencialista.

No entanto, é interessante observar como a jurisprudência da ADPF reforça a tese de que não pode haver limites para o controle de leis e normas orçamentárias por meio das demais ações de controle principal: ADI, ADC e ADO. Pois as decisões, como visto nos argumentos brevemente expostos, reconhecem a possibilidade de controle por esses meios, justamente para negar a possibilidade de controle por meio de ADPF.

O grande problema é que algumas decisões, como a da ADPF 63, reconhecem que o controle nas demais ações do controle principal poderia se dar quando presentes normas de caráter geral e abstrato. A se confirmar essa noção, haveria um vazio normativo de controle de constitucionalidade, no caso, das normas presentes em lei orçamentária sem caráter individual ou concreto, o que não pode prevalecer, sob pena de se deixar um vazio perigoso de abstenção.

Por fim, outro argumento encontrado nas decisões é o da inconstitucionalidade reflexa, isto é, da impossibilidade de controle de constitucionalidade por ADPF ou qualquer outro meio no controle principal, quando uma norma contraria outra indiretamente, atingindo o texto constitucional. 
No direito financeiro a noção é relevante por causa do fundamento de validade das leis orçamentárias, tratado no primeiro capítulo desta segunda e última parte da tese. Isto é, entre as leis orçamentárias foi estabelecida uma vinculação material, de forma que a LOA deve cumprir as disposições da LDO e do PPA, e a LDO, as disposições do PPA. Também não há razões para classificar esse argumento como consequencialista, visto que a falta de percepção consequencialista sobre tal noção pode causar prejuízos ao ordenamento, pois tais inconstitucionalidades podem também restar sem abrigo protetivo no ordenamento jurídico.

\subsection{Qual o precedente estabelecido pelo Supremo Tribunal Federal no controle de constitucionalidade de leis e normas orçamentárias?}

Diante da análise de todas as decisões realizada neste capítulo, este tópico pretende identificar o precedente ${ }^{458}$ hoje estabelecido pelo Supremo Tribunal Federal no controle principal de constitucionalidade de leis e normas orçamentárias.

Foi possível observar um desenrolar da jurisprudência, desde a promulgação da Constituição de 1988, de um paradigma onde leis orçamentárias eram consideradas leis homogeneamente concretas, insuscetíveis de controle por essas vias, como a ADI, para outro; neste, apenas as normas orçamentárias com caráter abstrato seriam suscetíveis, culminando no atual, em que não importa o caráter abstrato ou concreto da norma. Nesse sentido, pode-se observar uma evolução de um descontrole para um controle amplo de constitucionalidade de normas orçamentárias.

E a evolução jurisprudencial das decisões tomadas em controle abstrato pelo Supremo Tribunal Federal na aferição de constitucionalidade de normas orçamentárias é central na tese, representativa, como visto, não apenas do direito financeiro em si, mas de todo o controle realizado.

Primeiramente, alguns dados interessantes surgiram na pesquisa da jurisprudência sobre a matéria. Constatou-se a grande presença de ações que têm como objeto Leis de Diretrizes Orçamentárias, em maior número do que as ações sobre Leis

\footnotetext{
${ }^{458}$ No sentido posto por Marinoni: "decisão dotada de determinadas características, basicamente a potencialidade de se firmar como paradigma para a orientação dos jurisdicionados e dos magistrados". MARINONI, Luiz Guilherme. Precedentes Obrigatórios. 2ª ed. São Paulo: Saraiva, 2011, p. 215.
} 
Orçamentárias Anuais e Planos Plurianuais. Além disso, ainda mais recentemente, há também uma grande área de litígio no campo das medidas provisórias em matéria financeira, apesar de a Constituição ter tratado do tema com exaustão.

Segue tabela que consolida os dados dos acórdãos que foram escolhidos para análise:

\begin{tabular}{|c|c|c|c|c|c|}
\hline $\begin{array}{c}\text { NÚMERO DA } \\
\text { AÇÃO }\end{array}$ & $\begin{array}{c}\text { NATUREZA } \\
\text { DA } \\
\text { DECISÃO }\end{array}$ & $\begin{array}{c}\text { NATUREZA DA } \\
\text { NORMA }\end{array}$ & DECISÃO & CONHECIDA & RESULTADO \\
\hline ADI 1.640/DF & Principal & LOA & Unânime & Não & $\begin{array}{c}\text { Prejudicada a } \\
\text { cautelar }\end{array}$ \\
\hline ADI 2.100/RS & Principal & LDO & Maioria & Não & -------- \\
\hline ADI 2.108/PE & Liminar & LDO & Maioria & Parcialmente & Deferida \\
\hline ADI 2.535/MT & Liminar & LDO & Maioria & Sim & Deferida \\
\hline ADI 2.925/DF & Principal & CIDE & Maioria & Sim & $\begin{array}{c}\text { Procedente em } \\
\text { parte }\end{array}$ \\
\hline ADI 4.048/DF & Liminar & MP & Maioria & Sim & Deferida \\
\hline ADI 4.049/DF & Liminar & MP & Maioria & Sim & Deferida \\
\hline ADI 4.904/DF & Liminar & MP & Monocrática & Sim & Indeferida \\
\hline
\end{tabular}

Interessante que a ADI 2.108 (parcialmente) e a ADI 2.535 já haviam reconhecido a possibilidade de controle de constitucionalidade por via principal de lei ou norma orçamentária, mas apenas a ADI 2.925 foi tida como precedente para os julgamentos futuros. Para a formação do precedente, portanto, não basta ser a primeira decisão; é preciso que ela se confirme no futuro como relevante para os demais casos e seja referendada pelas demais na jurisprudência.

Alguns trabalhos recentes trataram dessa evolução jurisprudencial do Supremo em relação ao controle de constitucionalidade das leis orçamentárias e com conclusões diversas.

Numa obra de referência do direito financeiro, ${ }^{459}$ três artigos trataram do tema. O primeiro, de Sérgio Assoni Filho, reconhece uma abertura das possibilidades de controle. Assim, o paradigma anterior era baseado na ideia do não controle, por caracterizar a lei orçamentária como lei meramente formal ${ }^{460}$, passando a uma "ruptura" na ADI 4.048, que teria reconhecido a possibilidade de controle abstrato das leis

\footnotetext{
${ }^{459}$ CONTI, José Maurício \& SCAFF, Fernando Facury (Org.). Orçamentos Públicos e Direito Financeiro. São Paulo: Revista dos Tribunais, 2011.

${ }^{460}$ Neste caso, vide ADI 1.640.
} 
orçamentárias, muito embora a decisão no caso seja a de uma medida provisória que não era o meio adequado para disciplinar a matéria de natureza orçamentária, mas sim a lei. ${ }^{461}$

Noutro artigo publicado no mesmo livro, Celso de Barros Correia Neto afirma que o caráter de lei formal ou de efeitos concretos não seria questionado na ADI 4.048. Em outras palavras, não haveria ruptura, mas uma continuidade da decisão prolatada na ADI 2.925, de 2003, que julgou inconstitucional parte da lei orçamentária que não era considerada de efeitos concretos. ${ }^{462}$

No terceiro, de autoria de Eliana F. Neme e Luiz Alberto D. Araujo, a ADI 4.048 é tida como uma consolidação da decisão na ADI 2.925. Essa discussão é importante não apenas para o estudo dos orçamentos públicos, assim como para entender os mecanismos e limites do controle de constitucionalidade como um todo, embora as leis orçamentárias possam ser vistas como leis sui generis. ${ }^{463}$

No mesmo sentido, afirma José Levi do Amaral Júnior que, “em decisão histórica”, o STF superou, ao menos em parte, a jurisprudência anterior, suspendendo na ADI 4.048/DF a vigência da Medida Provisória $n^{\circ} 405$, e que a corte teria admitido examinar se as rubricas eram ou não imprevisíveis e urgentes, cujo entendimento foi reiterado na ADI 4.049-9/DF. ${ }^{464}$

Podemos afirmar que, diante da pesquisa feita, o precedente no direito brasileiro, isto é, a decisão que deve orientar a produção das demais, inclusive, e principalmente, as próximas decisões do Supremo Tribunal Federal, é a ADI 4.048.

Ela difere da ADI 2.925 por não mais exigir a demonstração de que a norma veiculada pela lei orçamentária possui natureza geral e abstrata, bastando que conste em veículo dotado de força de lei, como as leis ordinárias e as medidas provisórias.

Não se pode dizer, portanto, que hoje a distinção ultrapassada entre lei formal e lei material foi completamente abandonada pelo Supremo Tribunal Federal. Diante do julgamento da ADI 4.049, o paradigma é o de que basta ser lei formal para que seja passível do controle abstrato ou principal de constitucionalidade. Apenas no caso de atos

\footnotetext{
${ }^{461}$ ASSONI FILHO, Sérgio. Controle de Constitucionalidade de Lei Orçamentária. In CONTI, José Maurício \& SCAFF, Fernando Facury (Org.). Orçamentos Públicos e Direito Financeiro. São Paulo: Revista dos Tribunais, 2011.

${ }^{462}$ CORREIA NETO, Celso de Barros. O Orçamento Público e o Supremo Tribunal Federal. In CONTI, José Maurício \& SCAFF, Fernando Facury (Org.). Orçamentos Públicos e Direito Financeiro. São Paulo: Revista dos Tribunais, 2011.

463 NEME, Eliana F. \& ARAUJO, Luiz Alberto D. O Controle de Constitucionalidade Concentrado de Normas Orçamentárias. In CONTI, José Maurício \& SCAFF, Fernando Facury (Org.). Orçamentos Públicos e Direito Financeiro. São Paulo: Revista dos Tribunais, 2011.

464 AMARAL JÚNIOR, José Levi M. do. Medida Provisória: edição e conversão em lei. São Paulo: Saraiva, 2012, p. 127.
} 
normativos diversos de lei seria exigido o caráter de abstração. Essa noção pode ser contraditória à possibilidade de controle de Medidas Provisórias sobre a questão orçamentária, quando outro instrumento diverso de lei dispõe normas "de efeito concreto" e mesmo assim estas sofrem controle de constitucionalidade.

A ADI 2.925, portanto, neste momento histórico, parece não mais compor o precedente judicial, isto é, não deve mais servir como orientação para as decisões futuras em razão justamente do entendimento da ADI 4.048 que diverge da sua disposição.

\subsection{Conclusões sobre o impacto dos argumentos consequencialistas nas decisões do controle de constitucionalidade de leis e normas orçamentárias no Brasil}

Feita uma análise individual em cada acórdão, resta agora traçar um panorama sobre o uso de argumentos consequencialistas e a sua preponderância ou não nas decisões proferidas pelo Supremo Tribunal Federal.

A escolha de tal critério distintivo na análise argumentativa se deu pela necessidade de avaliar o que o Supremo Tribunal Federal pensa acerca das consequências de suas decisões. A hipótese era a de que no caso de questões orçamentárias, com grande repercussão social e jurídica, essas decisões trariam argumentos com tais preocupações.

Foi possível observar a presença de argumentos consequencialistas nas decisões do controle de constitucionalidade principal de leis e normas orçamentárias. No entanto, não se observou um abuso de argumentos dessa natureza.

Foram identificados poucos argumentos consequencialistas que não apresentassem uma consequência juridicamente tutelada e que pudessem ser classificados como extrajurídicos.

Os argumentos consequencialistas jurídicos foram encontrados especialmente nas duas principais decisões analisadas, as ADIs 2.925 e 4.048. Esses, sem dúvida, foram os acórdãos que mais apresentaram argumentos decisivos, ratio decidendi, dessa natureza.

Foram também os acórdãos que mais divergiram do paradigma jurisprudencial anterior. É possível afirmar, diante disso, que nos acórdãos analisados, quando há mudanças jurisprudenciais, há também um incremento de argumentos e raciocínios consequencialistas. Isto é, no momento de mudança jurisprudencial os argumentos 
deontológicos parecem enfraquecer, abrindo espaço argumentativo para razões consequencialistas.

Os argumentos dessa natureza, nas decisões analisadas, foram de extrema importância para a evolução jurisprudencial e a mudança dos paradigmas no tempo.

Uma prova da importância do raciocínio consequencialista na evolução da jurisprudência do Supremo Tribunal Federal é que os mesmos argumentos consequencialistas foram encontrados nas ADIs 2.925 e 4.048, especialmente o argumento sobre o perigo do descontrole de constitucionalidade.

As ADIs, contudo, divergiram em torno de um raciocínio deontológico, sobre a possibilidade de analisar "leis de efeitos concretos".

Na ADI 2.925 não era necessário mudar a jurisprudência do Supremo Tribunal Federal de não conhecer atos concretos, apenas reconhecer que a lei orçamentária possui diversos tipos de normas, e que aquela apresentava características gerais e abstratas. A jurisprudência, nesse caso, foi parcialmente modificada para conhecer a ação, com base em argumentos consequencialistas.

$\mathrm{Na}$ ADI 4.048, diferentemente, não se poderia realizar o controle sem que a jurisprudência mudasse completamente, reconhecendo a possibilidade de analisar a constitucionalidade de normas concretas. É que as normas analisadas nesta ADI não apresentavam caráter abstrato.

O que há em comum, portanto, é a necessidade e a disposição do Tribunal de não deixar nenhuma norma fora do controle de constitucionalidade principal, pelas diversas razões que foram expostas, mas especialmente porque livrar as leis e normas orçamentárias do controle de constitucionalidade principal significaria livrá-las de qualquer controle, tendo em vista que o controle incidental não é eficiente nesses casos.

A hipótese de que argumentos consequencialistas são utilizados pelo Supremo Tribunal Federal no controle da constitucionalidade de leis e normas orçamentárias foi confirmada, porquanto seu uso é mais intenso em decisões que quebram paradigmas anteriores, estabelecendo novos precedentes. 


\section{CONCLUSÕES}

A tese se propôs a analisar os sistemas de controle de constitucionalidade das leis e normas orçamentárias no Brasil sob uma perspectiva da argumentação jurídica. Todo o percurso desenvolvido nos cinco primeiros capítulos teve como objetivo fundamentar as análises desenvolvidas neste último capítulo que antecede esta conclusão.

Há dois tipos principais de conclusão que podem ser feitos. Num são apontadas as principais escolhas teóricas, demonstrados todos os avanços que o trabalho alcançou. Noutro, a conclusão serve para elaborar um desfecho, uma espécie de análise prognóstica do tema, especulando sobre as possíveis repercussões no futuro. Aqui, ambos os tipos serão desenvolvidos.

Em primeiro lugar, um resumo dos objetivos alcançados.

A tese foi dividida em duas partes, com o marco teórico, abordado na primeira, e a análise positiva e jurisprudencial, na segunda.

No primeiro capítulo, os pressupostos da análise argumentativa retórica foram vistos, fixando métodos que seriam utilizados especialmente no último capítulo da tese. Nele se deu a fixação de premissas, não alinhadas a um aspecto silogístico tradicional, mas construídas a partir do referencial da retórica, do entimema, procurando descobrir o que há de convincente em cada argumento. Além disso, foram vistos os requisitos para a formação de precedentes no direito, partindo, da mesma forma, da análise argumentativa sobre aquilo que é essencial, ratio decidendi, e aquilo que é periférico, obiter dictum, na decisão.

No segundo capítulo começou-se a observar o debate entre a análise consequencialista e a análise deontológica, expondo-se os aspectos mais relevantes das principais teorias que defendem algum tipo de análise fundada nas consequências da decisão, como o utilitarismo, o pragmatismo e a análise econômica do direito. Viu-se também que essas teorias apresentam visões diversas sobre, especialmente, que tipo de consequência deve ser avaliado, e em que situações ela pode ser considerada validamente num ordenamento jurídico.

Essa divergência abriu espaço para o estudo da teoria do jurista escocês Neil MacCormick, que propôs um consequencialismo essencialmente jurídico, fundado na ideia de universalidade. Esta reside na noção de que todas as decisões, mesmo que produzam efeitos individuais, devem ser decididas como se fossem universais, sob a ideia de que qualquer um naquela mesma situação deve receber o mesmo tratamento jurídico. Nessa 
linha, para MacCormick, todas as decisões devem cumprir um triplo requisito para que sejam consideradas como boas decisões. Seriam os três Cs: consistência, coerência e consequências.

Não é qualquer tipo de consequência que deveria ser avaliada pelo juiz, segundo o jurista escocês, mas apenas poderiam ser consideradas jurídicas as consequências relacionadas à mensagem jurídica emanada da decisão, no sentido conjugado com a ideia de universalidade. Isto é, os juízes devem avaliar como as pessoas agirão diante daquela decisão, caso seja tomada como um precedente, e esse tipo de consequência o juiz não poderia deixar de observar, nem afirmar que a ele não seria possível observá-la em cada caso.

Tomou-se de empréstimo da teoria de MacCormick o sentido de consequencialismo jurídico, para ainda na primeira parte da tese defender que há dois tipos de argumentos que podem ser considerados consequencialistas no direito. Um primeiro, que prevê as consequências sociais, econômicas, culturais de uma decisão, chamado de argumento consequencialista extrajurídico, e outro, fundado na ideia de que a decisão deve prever as repercussões jurídicas que dela emanam, chamado de argumento consequencialista jurídico.

Fundadas tais premissas teóricas do trabalho, iniciou-se a segunda parte da tese, analisando-se o sistema positivo do direito financeiro brasileiro no que tange às leis orçamentárias. Foram observados os possíveis conteúdos das normas que integram o orçamento público, com o objetivo de fixar a natureza jurídica das normas que integram as leis orçamentárias.

Foi possível definir de início que as leis orçamentárias não são leis de conteúdo homogêneo, sobre o qual se pode fixar uma natureza única e imutável, como fizeram algumas decisões sobre a matéria, que consideravam as leis orçamentárias como "leis de efeitos concretos".

Superada essa primeira noção, observou-se que as três leis orçamentárias possuem normas de diversas naturezas. A discussão, na verdade, gira em torno do que Kelsen e Bobbio trataram como a fixação dos destinatários das normas, em normas individuais ou gerais, e quanto ao conteúdo das normas, em concreto ou abstrato, a depender da inesgotabilidade da sua incidência.

Com relação à Lei Orçamentária Anual, pôde-se definir que os dispositivos que fixam as despesas produzem um número reduzido de normas jurídicas, uma vez que a previsão da receita serve basicamente, do ponto de vista jurídico, para autorizar o montante 
destinado à fixação das despesas pela mesma lei orçamentária. Trata-se, portanto, de normas concretas, pois uma vez produzida a sua incidência, esgotam-se.

No caso das despesas públicas, foi observado que também constituem normas concretas, pois a cada realização de despesa, sua incidência se esgota parcial ou totalmente. Porém, na hipótese de normas constantes nas leis orçamentárias anuais que disciplinam a abertura de créditos suplementares, ter-se-iam normas de caráter abstrato, pois elas regulam abstratamente situações que podem ocorrer incontáveis vezes, não se esgotando sua incidência em cada uma delas.

Ainda nesse capítulo o fundamento de validade dessas leis orçamentárias foi tratado, constatando-se que elas possuem conteúdos constitucionalmente vinculados uns aos outros (artigos 165, $\S 2^{\circ}$ e $166, \S 3^{\circ}$, I), mas que todas elas são de mesma hierarquia, buscando seu fundamento de validade diretamente no texto constitucional.

Esse tema do fundamento de validade na Constituição remete ao que se seguiu, o do controle de constitucionalidade das normas dessa natureza. É que o fundamento de validade na Constituição e a proteção do texto constitucional são a essência da criação desses modelos de proteção.

Não se buscou apresentar um modelo detalhado sobre o sistema brasileiro, mas sim tratar de detalhes que possuam relevância prática para a discussão das peculiaridades no controle de leis e normas orçamentárias.

Defendeu-se, na linha de Elival da Silva Ramos, que a natureza do sistema de controle de constitucionalidade brasileiro é difusa, ou seja, que qualquer juiz pode declarar a inconstitucionalidade de uma lei. E também que a divisão de competências, com a qual o Supremo Tribunal Federal e os Tribunais de Justiça dos estados reservam para si a via principal, não cria um sistema de controle concentrado.

Duas vias, portanto, no sistema brasileiro foram apontadas, com destaque para a via principal, mais adequada ao controle de constitucionalidade de leis orçamentárias. Isso porque a via incidental, que exige o ferimento ao direito subjetivo do autor da ação, é, embora igualmente possível, limitada. Isso porque as questões orçamentárias são sempre públicas, com enorme interesse social, e a periodicidade dessas leis impediria que um processo regular chegasse ao Supremo Tribunal Federal, guardião da Constituição.

Eleita a via principal como objeto de análise da tese, foram vistas as suas ações, a saber, ADI, ADO, ADC e ADPF, sempre em relação às limitações e características que interessam ao controle das leis orçamentárias. 
Defendeu-se que não há no texto constitucional ou infraconstitucional, isto é, nas leis que regulam o funcionamento das ações do controle principal, referência alguma à limitação no que diz respeito a normas cujo objeto seja concreto e não abstrato. Assim, por exemplo, quando o artigo constitucional 102, I, $a$, menciona a competência do Supremo Tribunal Federal para julgar por ADI e ADC de lei ou ato normativo, não se pode interpretar que normas concretas não seriam normativas. Isso por dois motivos: 1) a palavra normativa, embora o STF tenha entendido assim por um tempo, não se refere à lei, mas apenas à expressão "ato", porquanto seria redundante falar em lei normativa; 2) a palavra normativa não significa restrição às normas jurídicas concretas, pois, de acordo com os maiores mestres do tema, Kelsen e Bobbio, normas concretas, ainda assim, são normas jurídicas, com força normativa, por assim dizer.

O último capítulo se destinou a confirmar a hipótese do trabalho, que era a de que o Supremo Tribunal Federal utiliza-se de argumentos consequencialistas para admitir o controle de constitucionalidade de leis e normas orçamentárias. Abordou também a subhipótese de que haveria uma evolução no sentido de que o Supremo vinha alargando as possibilidades de controlar a constitucionalidade de leis e normas orçamentárias por via principal, não deixando a tarefa apenas para a via incidental, menos eficaz.

Foram analisadas as principais decisões no controle de constitucionalidade de todas as ações possíveis: ADI, ADC, ADO e ADPF. Verificou-se que abundam decisões, conhecendo ou não, no caso das ADIs, a controlar a constitucionalidade de leis e normas orçamentárias.

No caso da ADC, nenhuma ação até hoje foi proposta. O que é compreensível, pois as Ações Declaratórias de Constitucionalidade não são adequadas para instrumentos periódicos como as leis orçamentárias, uma vez que se prestam a prevenir litígios, unificando a interpretação diretamente pelo órgão que centraliza a constituição da invalidade.

No caso das ADOs, pouquíssimos casos foram propostos - apenas três, e desses três, apenas um foi efetivamente julgado, pela supressão posterior da omissão, restando dois casos pendentes de julgamento.

Vários casos de ADPFs foram julgados, porém, em virtude da natureza subsidiária dessas ações, e entendendo-se que as leis e normas orçamentárias podem sim ser apreciadas em sede de ADI, há uma impossibilidade, a priori, de se conhecer ações dessa natureza sobre matéria orçamentária. 
As ADIs são os instrumentos mais adequados para esse tipo de controle, e são as que apresentam o maior número de decisões sobre esses casos. É possível observar, confirmando a sub-hipótese, uma evolução na jurisprudência do Supremo Tribunal Federal sobre a matéria, para um estado de não conhecer as ações no controle principal que tratem de matéria orçamentária, destinando-as a um segundo estágio, no qual apenas as normas caracterizadas como abstratas sofreriam o controle principal, seguindo então para um terceiro, em que não há mais a exigência da generalidade e abstração das normas orçamentárias para que elas se submetam ao processo principal.

Essa tendência observada - consubstanciada na ADI 4.048 - apenas foi confirmada em uma ADI 4.049. Esta cita expressamente a anterior como precedente na matéria, posto que, também, a ADI 4.904 não tenha sido conhecida por decisão liminar, levando à perda do objeto e à não decisão sobre o caso.

Infelizmente, portanto, o precedente estabelecido na ADI 4.048 não vem impedindo a produção de medidas provisórias inconstitucionais. No dia trinta de dezembro do ano de 2013 foi produzida outro instrumento dessa natureza, a MP de $\mathrm{n}^{\mathrm{o}}$ 637, estabelecendo uma série de despesas que claramente não se adequam aos requisitos constitucionais.

E, por outro lado, o não conhecimento da ADI 4.904, apenas reforçam a pouca força que os precedentes produzem no Brasil. Mesmo no âmbito do controle de constitucionalidade principal, realizado pelo Supremo Tribunal Federal, as decisões não produzem o efeito desejado na orientação das condutas que a sucedem, nem pelo Executivo, nem mesmo pelo Judiciário, nesse caso.

É preciso, portanto, esperar as próximas decisões que serão tomadas pelo Supremo Tribunal Federal sobre a matéria, para que se confirme a ADI no 4.048 como precedente vigente, que estabelece a possibilidade de conhecimento das ações do controle principal não só de matéria orçamentária, mas de todo tipo de lei que apresente normas concretas ou individuais.

Ou seja, que não é mais necessário demonstrar a generalidade e abstração das normas para ter acesso ao controle principal de constitucionalidade no Brasil.

Por fim, sobre a hipótese central deste trabalho, do uso de argumentos consequencialistas jurídicos nas decisões do controle de constitucionalidade de normas orçamentárias pelo Supremo Tribunal Federal, observou-se uma vasta utilização desses argumentos nas decisões, especialmente naquelas que serviram como precedente sobre a matéria, as ADIs $n^{\circ} 2.925$ e $n^{\circ}$ 4.048. Pode-se afirmar que nessas ADIs o argumento 
consequencialista foi o principal argumento para conhecer as ações, no sentido de que caso não fosse conhecidas, as consequências para o ordenamento seriam nefastas, pois leis da maior importância, jurídica e social, estariam descobertas de qualquer controle de constitucionalidade, sendo constatada pelos Ministros a insuficiência do controle incidental para proteger a supremacia da Constituição em tais casos.

Não se pode, destarte, fazer muitas críticas ao Supremo Tribunal Federal do ponto de vista do uso de argumentos consequencialistas extrajurídicos. Eles foram usados de forma pontual e não comprometeram a qualidade das decisões proferidas em análise. 


\section{REFERÊNCIAS}

ABBAGNANO, Nicola. Dicionário de Filosofia. São Paulo, Martins Fontes, 1998.

ADEODATO, João Maurício. Uma Teoria Retórica da Norma Jurídica e do Direito Subjetivo. São Paulo: Noeses, 2011.

A Retórica Constitucional: sobre tolerância, direitos humanos e outros fundamentos éticos do direito positivo. São Paulo, Saraiva, 2010.

ANDRADE, Fábio Martins. Modulação em Matéria Tributária: o argumento pragmático ou consequencialista de cunho econômico e as decisões do STF. São Paulo: Quartier Latin, 2011.

ALEXY, Robert. A Theory of Legal Argumentation: the theory of rational discourse as theory of legal justification. OXFORD: Oxford University Press, 2010.

Direito, Razão, Discurso: estudos para a filosofia do direito. Luís Afonso Heck (Trad.). Porto Alegre: Livraria do Advogado, 2010.

Precedent in the Federal Republic of Germany, in MACCORMICK, Neil \& SUMMERS, Robert S. Interpreting Precedents: a comparative study. Aldershot: Darthmouth Publishing Company Limited, 1997.

AMARAL JÚNIOR, José Levi M. do. Medida Provisória: edição e conversão em lei. São Paulo: Saraiva, 2012.

ANDRADE, Fábio Martins. Modulação em Matéria Tributária: o argumento pragmático ou consequencialista de cunho econômico e as decisões do STF. São Paulo: Quartier Latin, 2011.

ARAÚJO, Luiz Alberto D. de; SERRANO JÚNIOR, Vidal. Curso de Direito Constitucional. São Paulo: Saraiva, 2010. 
ARISTÓTELES. Retórica. Trad. Edson Bini. São Paulo: Edipro, 2011.

ASSIS, Luiz Gustavo Bambini. Processo Legislativo e o Orçamento Público: função de controle do Parlamento. São Paulo: Saraiva, 2012.

ASSONI FILHO, Sérgio. Controle de Constitucionalidade de Lei Orçamentária, in CONTI, José Maurício \& SCAFF, Fernando Facury (Org.). Orçamentos Públicos e Direito Financeiro. São Paulo: Revista dos Tribunais, 2011.

ATIENZA, Manuel. Curso de Argumentación Jurídica. Madrid: Editorial Trotta, 2013.

As Razões do Direito: teorias da argumentação jurídica. $3^{\text {a }}$ ed. Trad. Maria Cristina G. Cupertino. São Paulo: Landy Editora, 2006.

BALEEIRO, Aliomar. Uma Introdução à Ciência das Finanças. 14ª ed. Rio de Janeiro: Forense, 1996.

BARBOSA, Ruy. Os Actos Inconstitucionaes do Congresso e do Executivo ante a Justiça Federal. Rio de Janeiro: Companhia Impressora, 1893.

BARROSO, Luís Roberto \& MENDONÇA, Eduardo. Sistema Constitucional Orçamentário, in Martins, Ives Gandra da Silva; MENDES, Gilmar F.; NASCIMENTO, Carlos Valder do. Tratado de Direito Financeiro. Volume 2. São Paulo: Saraiva, 2013.

BECKER, Alfredo Augusto. Teoria Geral do Direito Tributário. $3^{\text {a }}$ ed. São Paulo: Lejus, 1998.

BERNARDES, Juliano T. Controle Abstrato de Constitucionalidade: elementos materiais e princípios processuais. São Paulo: Saraiva, 2004.

BILLIER, Jean-Cassien \& MARYOLI, Aglaé. História da Filosofia do Direito. Barueri: Manole, 2005. 
BITTAR, Eduardo C. B. Curso de Filosofia Aristotélica: leitura e interpretação do pensamento aristotélico. Barueri: Manoel, 2003.

BOBBIO, Norberto. Teoria da Norma Jurídica. 2a ed. Bauru: Edipro, 2003.

BONAVIDES, Paulo. Ciência Política. 10ª ed. 11ª tiragem. São Paulo: Malheiros, 2002.

BOUVIER, M.; ESClASSAN, M.; \& LASSALE, J. Finances Publiques. $8^{\mathrm{a}}$ ed. Paris: LGDJ, 2002.

BUStamante, Thomas da R. de. Teoria do Precedente Judicial: a justificação e a aplicação de regras jurisprudenciais. São Paulo: Noeses, 2012.

CALIENDO, Paulo. Direito Tributário e Análise Econômica do Direito: uma visão crítica. Rio de Janeiro: Elsevier, 2009.

CAnotilho, J. J. Gomes. Direito Constitucional e Teoria da Constituição. $7^{\mathrm{a}}$ ed. Coimbra: Almedina, 2000.

CAPPELlETtI, Mauro. O Controle Judicial de Constitucionalidade das Leis no Direito Comparado. $2^{\text {a }}$ ed. Porto Alegre: Sérgio Antonio Fabris Editor, 1999.

CARRERA RAYA, Francisco José. Manual de Derecho Financiero. Vol. III. Madrid: Tecnos, 1995.

CARVALHO. Paulo de Barros. Direito Tributário: fundamentos jurídicos da incidência. $8^{a}$ ed. São Paulo: Saraiva, 2010.

Direito Tributário: linguagem e método. $3^{\mathrm{a}}$ ed. Noeses: São Paulo, 2009.

CARVAlHO, Cristiano. Teoria da Decisão Tributária. São Paulo: Saraiva, 2013.

CATÃO, Adrualdo de Lima. Decisão Jurídica e Racionalidade. Maceió: Edufal, 2007. 
CHRISTOPOUlOS, Basile G. C. Despesa Pública: estrutura, função e controle judicial. Maceió: Edufal, 2011.

CIANCI, Mirna; ALMEIDA, Gregório A. de. Direito Processual do Controle de Constitucionalidade. São Paulo: Saraiva, 2011.

CLÈVE, Clèmerson Merlin. Atividade Legislativa do Poder Executivo no Estado Contemporâneo e na Constituição de 1988. São Paulo: Editora Revista dos Tribunais, 1993.

COASE, Ronald H. The Problem of Social Cost. The Journal of Law \& Economics. Vol. III. 1960.

CONSELHO NACIONAL DE JUSTIÇA. CNJ recomenda especialização de varas de fazenda pública para tratar de questões de saúde. Disponível em: < http://www.cnj.jus.br/noticias/cnj/25761:cnj-recomenda-aos-tribunais-a-criacao-de-varaspara-saude>. Acesso em 10.01.2014.

CORREIA NETO, Celso de Barros. O Orçamento Público e o Supremo Tribunal Federal, in CONTI, José Maurício \& SCAFF, Fernando Facury (Coord.). Orçamentos Públicos e Direito Financeiro. São Paulo: Editora Revista dos Tribunais, 2011.

CONTI, José Maurício \& SCAFF, Fernando Facury (Org.). Orçamentos Públicos e Direito Financeiro. São Paulo: Revista dos Tribunais, 2011.

CONTI, José Maurício. O Plano Plurianual - PPA, in Martins, Ives Gandra da Silva; MENDES, Gilmar F.; NASCIMENTO, Carlos Valder do. Tratado de Direito Financeiro. Volume 2. São Paulo: Saraiva, 2013.

DANTAS, Bruno. Repercussão Geral: perspectiva histórica, dogmática e de direito comparado; questões processuais. São Paulo: Revista dos Tribunais, 2009.

DANTAS, Paulo R. de F. Direito Processual Constitucional. $3^{a}$ ed. São Paulo: Atlas, 2012. 
DIDIER JR., Fredie, BRAGA, Paula S. \& OLIVEIRA, Rafael. Curso de direito processual civil. Vol. 2, Teoria da prova, direito probatório, teoria do precedente, decisão judicial, coisa julgada e antecipação dos efeitos da tutela. Salvador: JusPODIVM, 2012.

DRIVER, Julia. Consequentialism. London: Routledge, 2012.

DUARTE. Tiago. A Lei por Detrás do Orçamento: a questão constitucional da lei do orçamento. Coimbra: Almedina, 2007.

FARALLI, Carla. A Filosofia Contemporânea do Direito: temas e desafios. São Paulo: Martins Fontes, 2006.

FERRAZ JR., Tércio. Introdução ao Estudo do Direito: técnica, decisão e dominação. $3^{\mathrm{a}}$ ed. São Paulo: Atlas, 2001.

FERREIRO LAPATZA, José Juan. Curso de Derecho Financiero Español. $25^{\mathrm{a}}$ ed. Madrid/Barcelona: Marcial Pons, 2006.

FONROUGE, Giuliani. Derecho Financiero. Vol. I. Buenos Aires: De Palma, 1962.

GARCÍA AMADO, Juan Antonio. Derechos y pretextos: elementos de crítica del neoconstitucionalismo. In: CARBONELL, Miguel (Ed.). Teoria del neoconstitucionalismo - ensayos escogidos. Madrid: Trotta, 2008.

GARNER, Bryan A. (Editor). Black's Law Dictionary. 9ª ed. St. Paul: Thomson Reuters, 2005.

GRAU, Eros Roberto. Planejamento Econômico e Regra Jurídica. São Paulo: Revista dos Tribunais, 1978.

HART, Herbert L. A. O Conceito de Direito. Lisboa: Fundação Calouste Gulbenkian, 2001. 
HURLEY, Paul. Beyond Consequentialism. Oxford: Oxford University Press, 2011.

ITÁLIA. La Costituzione della Repubblica Italiana. Disponível em: <http://www.governo.it/Governo /Costituzione/2_titolo1.html>. Acesso em 2.12.13.

IVO, Gabriel . Direito Tributário e Orçamento Público, in Direito Tributário: homenagem a Paulo de Barros Carvalho. Luís Eduardo Schoueri (Org.). São Paulo: Quartier Latin, 2008.

JAMES, William. Pragmatismo. Trad. Jorge Caetano da Silva. São Paulo: Martin Claret, 2006.

JARACH, Dino. Finanzas Públicas y Derecho Tributário. Caracas: Ediciones Nuevo Mundo Siglo XXI, 2007.

KANT, Immanuel. Crítica da Razão Prática. Trad. Valerio Rohden. São Paulo: Martins Fontes, 2011.

KELSEN, Hans. O Controle Judicial da Constitucionalidade: um estudo comparado das Constituições austríaca e americana, in Jurisdição Constitucional. São Paulo: Martins Fontes, 2007.

. Teoria Geral das Normas. Porto Alegre: Fabris, 1986.

. Teoría Pura Del Derecho. Buenos Aires: Editorial Universitaria de Buenos Aires, 1960.

KOYRÉ, Alexandre. Introdução à Leitura de Platão. Lisboa, Editorial Presença, 1988.

LABAND, Paul. Le Droit Public de L'Empire Allemand. Paris: V. Giard \& E. Briere, 1904. 
MACCORMICK, Neil. Argumentação Jurídica e Teoria do Direito. São Paulo: Martins Fontes, 2006.

. Pratical Reason in Law and Morality. Oxford: Oxford University Press, 2008 .

Legal Reasoning and Legal Theory. Oxford: Clarendon Press, 1994.

. Retórica e o Estado de Direito. Trad. Conrado Hübner Mendes. Rio de Janeiro: Elsevier, 2008.

Rhetoric and the Rule of Law: a theory of legal reasoning. Oxford: Oxford University Press, 2005.

H. L. A. Hart. Trad. Claudia Santana Martins. Rio de Janeiro: Elsevier, 2010.

. Precedent as a source of Law, in ATTWOOL, Elspeth, e COMMANDUCCI, Paolo (org.). Sources of Law and Legislation: proceedings of the $17^{\text {th }}$ World Congress of the International Association for Philosophy of Law and Social Philosophy (IVR). Bologna: IVR, 1995.

MACCORMICK, Neil \& SUMMERS, Robert S. Interpreting Precedents: a comparative study. Aldershot: Darthmouth Publishing Company Limited, 1997.

MACEDO JUNIOR, Ronaldo Porto. Ensaios de Teoria do Direito. São Paulo: Saraiva, 2013.

MARINONI, Luiz Guilherme. Precedentes Obrigatórios. 2a ed. São Paulo: Saraiva, 2011.

MCCOY, Marina. Platão e a Retórica de Filósofos e Sofistas. Trad. Lívia Oushiro. São Paulo, Madras, 2010. 
MENDES, Conrado H. Lendo uma decisão: obiter dictum e ratio decidendi, racionalidade e retórica na decisão. Sociedade Brasileira de Direito Público. Disponível em: <http://www.sbdp.org.br/arquivos/material/19_Estudo\%20dirigido\%20-\%20Ratio $\% 20$ decidendi $\% 20 \mathrm{e} \% 20$ obter\%20dictum\%20-\%20Conrado\%20Hubner\%20Mendes. pdf $>$. Acesso em 24.10.2013.

MENDES, Gilmar Ferreira. Controle Abstrato de Constitucionalidade: ADI, ADC e ADO. São Paulo: Saraiva, 2012.

Anotações acerca da apreciação e revisão de fatos e prognoses legislativos perante a Corte Constitucional alemã e o Supremo Tribunal Federal brasileiro, in RAMOS, Elival da Silva; MORAIS, Carlos Blanco de (Coord.). Perspectivas de Reformas da Justiça Constitucional em Portugal e no Brasil. Coimbra: Almedina, 2012.

MENDES, Gilmar Ferreira \& MARTINS, Ives Gandra da S. Controle Concentrado de Constitucionalidade: comentários à Lei n. 9.868, de 10-11-1999. $3^{\text {a }}$ ed. São Paulo: Saraiva, 2009.

MEYER, Michel. A Retórica. São Paulo: Ática, 2007.

MIRANDA, Jorge. Manual de Direito Constitucional: inconstitucionalidade e garantia da Constituição. Tomo IV. $4^{\text {a }}$ ed. Coimbra: Coimbra Editora, 2013.

MORETO, Mariana C. L. O Precedente Judicial no Sistema Processual Brasileiro. Tese de Doutorado. Faculdade de Direito da Universidade de São Paulo. São Paulo, 2012.

MOUSSALLEM, Tárek Moysés. Argumentação Consequencialista na Jurisprudência do Supremo Tribunal Federal, in SOUZA, Priscila de. Sistema Tributário Brasileiro e Crise Atual. VI Congresso Nacional de Estudos Tributários. São Paulo: Noeses, 2009.

MULGAN, Tim. The Demands of Consequentialism. Oxford: Oxford University Press, 2001. 
NEME, Eliana F. \& ARAUJO, Luiz Alberto D. O Controle de Constitucionalidade Concentrado de Normas Orçamentárias, in CONTI, José Maurício \& SCAFF, Fernando Facury (Org.). Orçamentos Públicos e Direito Financeiro. São Paulo: Revista dos Tribunais, 2011.

NÓBREGA, Flavianne F. B. Um Método para a Investigação das Consequências: a lógica pragmática da abdução de C. S. Pierce aplicada ao direito. João Pessoa: Ideia, 2013.

NÓBREGA, Marcos. Influências Internas e Externas da Lei de Responsabilidade Fiscal, in: FIGUEIREDO, Carlos Maurício; NÓBREGA, Marcos. Responsabilidade Fiscal: Aspectos polêmicos. Belo Horizonte: Fórum, 2006.

OLIVEIRA, Régis Fernandes. Curso de Direito Financeiro. 5ª ed. São Paulo: RT, 2013.

PALMA, Juliana B., FEFERBAUM, Marina, PINHEIRO, Victor M. Meu Trabalho Precisa de Jurisprudência? Como Posso Utilizá-la?, in QUEIROZ, Rafael Mafei \& FEFERBAUM, Marina. (Coord.) Metodologia Jurídica: um roteiro prático para trabalhos de conclusão de curso. São Paulo: Saraiva, 2012.

PERELMAN, Chaim \& OLBRECHTS-TYTECA, Lucie. Tratado da Argumentação: a nova retórica. Maria Ermantina de Almeida Prado Galvão (Trad.). São Paulo: Martins Fontes, 2005.

PERELMAN, Chaïm. Ética e Direito. $2^{\text {a }}$ ed. Trad. Maria Ermantina de A. P. Galvão. São Paulo: Martins Fontes, 2005.

PISCITELLI, Tathiane dos Santos. Interpretação e Justificação no Direito: o requisito da coerência, in SOUZA, Priscila de. Sistema Tributário Brasileiro e Crise Atual. VI Congresso Nacional de Estudos Tributários. São Paulo: Noeses, 2009.

PORTELLA, André. Lei Orçamentária Anual - LOA, in Martins, Ives Gandra da Silva; MENDES, Gilmar F.; NASCIMENTO, Carlos Valder do. Tratado de Direito Financeiro. Volume 2. São Paulo: Saraiva, 2013. 
PORTUGAL. Constituição da República Portuguesa. Disponível em: <http://www.parlamento.pt/Legislacao/Paginas/ConstituicaoRepublicaPortuguesa.aspx> Acesso em 12.11.2013.

Tribunal Constitucional. Acórdão no 187/2013. Disponível em: <http:// www.tribunalconstitucional.pt/tc/acordaos/20130187.html>. Acesso em 8.4.2013.

POSNER, Richard. Law, Pragmatism, and Democracy. Cambridge/London: Harvard University Press, 2003.

Utilitarianism, Economics, and Legal Theory, in The Journal of Legal Studies. Vol. 8, N. 1 (jan. 1979). Disponível em: <http://www.jstor.org/stable/724048>. Acesso em: 1.2.2012.

. Problemas de Filosofia do Direito. Trad. Jefferson Luiz de Camargo. São Paulo: Martins Fontes, 2010.

The Economics of Justice. Cambridge: Harvard University Press, 1981.

PRAKASH, Saikrishna. Radicals in Tweed Jackets: why extreme left-wing Law professors are wrong for America. Columbia Law Review. Vol. 106, N. 8, 2006. Disponível em: <http://www.jstor.org/stable/40041696>. Acesso em 1\%/2/2012.

QUEIROZ, Cristina. Direito Constitucional: as instituições do Estado Democrático e Constitucional. Coimbra: Coimbra Editora, 2009.

RAMIRES, Maurício. Crítica à Aplicação de Precedentes no Direito Brasileiro. Porto Alegre: Livraria do Advogado, 2010.

RAMOS, Elival da Silva. Ativismo Judicial: parâmetros dogmáticos. São Paulo: Saraiva, 2010.

A Evolução do Sistema Brasileiro de Controle de Constitucionalidade e a Constituição de 1988, in RAMOS, Elival da Silva; MORAIS, Carlos Blanco de (Coord.). 
Perspectivas de Reformas da Justiça Constitucional em Portugal e no Brasil. Coimbra: Almedina, 2012.

Arguição de Descumprimento de Preceito Fundamental: delineamento do instituto, in TAVARES, André Ramos; ROTHENBURG, Walter Claudius. Arguição de Descumprimento de Preceito Fundamental: análises à luz da Lei no 9.882/99. São Paulo: Atlas.

. Controle de Constitucionalidade no Brasil: perspectivas e evolução. São Paulo: Saraiva, 2010.

REBOUL, Olivier. Introdução à Retórica. São Paulo, Martins Fontes, 2004.

REALE, Giovani. Aristóteles. São Paulo, Edições Loyola, 2007.

ROGEIRO, Nuno. A Lei Fundamental da República Federal da Alemanha: com um ensaio e anotações de Nuno Rogeiro. Coimbra: Coimbra editora, 1996.

RORTY, Richard. Para Que Serve a Verdade? Trad. Antonio Carlos Olivieri. São Paulo: Editora Unesp, 2008.

ROTHENBURG, Walter Claudius. Velhos e Novos Rumos das Ações de Controle Abstrato de Constitucionalidade à Luz da Lei no 9.868/99, in SARMENTO, Daniel (Org.). O Controle de Constitucionalidade e a Lei 9.868/99. Rio de Janeiro: Lumen Iuris, 2002.

SALAMA, Bruno M. A História do Declínio e Queda do Eficientismo na Obra de Richard Posner, in LIMA, Maria Lúcia L. M. (coord.). Agenda Contemporânea: direito e economia. São Paulo: Saraiva, 2012.

SARMENTO, Daniel. A Eficácia Temporal das Decisões no Controle de Constitucionalidade, in SARMENTO, Daniel (Org.). O Controle de Constitucionalidade e a Lei 9.868/99. Rio de Janeiro: Lumen Iuris, 2002. 
SCAFF, Fernando Facury. A Constituição Econômica Brasileira em seus 15 anos, in SCAFF, Fernando Facury. Constitucionalizando Direitos: 15 anos da Constituição Brasileira de 1988. Rio de Janeiro: Renovar, 2003.

Quando as Medidas Provisórias se transformaram em Decretos-lei ou Notas sobre a Reserva Legal Tributária no Brasil, in SCAFF, Fernando Facury \& MAUÉS, Antonio G. Moreira. Justiça Constitucional e Tributação. São Paulo: Dialética, 2005.

SCHEFFLER, Samuel. From the Rejection of Consequentialism, in DARWALL, Stephen (Org.). Consequentialism. Oxford: Blackwell Publishing, 2003.

SCHUARTZ, Luis Fernando. Consequencialismo jurídico, racionalidade decisória e malandragem, in MACEDO JR, Ronaldo Porto \& BARBIERI, Catarina H. Cortada. Direito e Interpretação: racionalidades e instituições. São Paulo: Saraiva, 2011.

SEN, Amartya. Utilitarism and Welfare, in DARWALL, Stephen (org.). Consequentialism. Oxford: Blackwell Publishing, 2003.

SILVA, José Afonso da. Curso de Direito Constitucional Positivo. 24a ed. São Paulo: Malheiros, 2005.

Orçamento-Programa, in Martins, Ives Gandra da Silva; MENDES, Gilmar F.; NASCIMENTO, Carlos Valder do. Tratado de Direito Financeiro. Volume 2. São Paulo: Saraiva, 2013.

SOUSA FRANCO, António L. de. Finanças Públicas e Direito Financeiro. Vol. I e II. $4^{\text {a }}$ ed. Coimbra: Almedina, 2007.

STRECK, Lênio. Da Interpretação dos Textos à Concretização de Direitos: a incindibilidade entre interpretar e aplicar a partir da diferença ontológica (ontologische differentz) entre texto e norma, in Constituição, Sistemas Sociais e Hermenêutica Anuário do Programa de Pós-Graduação em Direito da Unisinos. Porto Alegre, 2006. 
Jurisdição Constitucional e Decisão Jurídica. $3^{\text {a }}$ ed. São Paulo: Revista dos Tribunais, 2013.

STUART MILL, John. Utilitarismo. Trad. Rita de Cássia G. Neiva. São Paulo: Escala, 2007.

STUBBS, Anne. The Pros and Cons of Consequentialism. Philosophy. Vol. 56, $\mathrm{n}^{\mathrm{o}}$ 218, Cambridge University Press, 1981.Disponível em: <http://www.jstor.org/stable/3750884>. Acesso em 1\%/2/2012.

SUMMERS, Robert S. Precedent in the United States (New York State), in MACCORMICK, Neil \& SUMMERS, Robert S. Interpreting Precedents: a comparative study. Aldershot: Darthmouth Publishing Company Limited, 1997.

TAVARES, André Ramos. Paradigmas do Judicialismo Constitucional. São Paulo: Saraiva, 2012.

TORRES, Ricardo Lobo. Tratado de Direito Constitucional Financeiro e Tributário. Vol. V. O Orçamento e a Constituição. Rio de Janeiro: Renovar, 2008.

TOULMIN, Stephen E. Os Usos do Argumento. São Paulo: Martins Fontes, 2006.

TUCCI, José Rogério Cruz e. Precedente judicial como fonte do direito. São Paulo: RT, 2004.

VIEHWEG, Theodor. Tópica e Jurisprudência: uma contribuição à investigação dos fundamentos jurídico-científicos. Trad. Kelly S. Alflen da Silva. Porto Alegre: Sergio Antonio Fabris Editor, 2008.

VILANOVA, Lourival. As Estruturas Lógicas e o Sistema do Direito Positivo. São Paulo: Noeses, 2005. 
VOJVODIC, Adriana de Moraes. Precedentes e Argumentação no Supremo Tribunal

Federal: entre a vinculação ao passado e a sinalização para o futuro. Tese de Doutorado. Faculdade de Direito da Universidade de São Paulo. São Paulo, 2012. 